\title{
Annotated Bibliography on
}

Hydrology and Sedimentation

United States and Canada

$1955-58$

Compiled by H. C. RIGGS

GEOLOGICAL SURVEY WATER-SUPPLY PAPER 1546

Prepared in cooperation with the Subcommittees on Hydrology and Sedimentation, Inter-Agency Committee on Water Resources

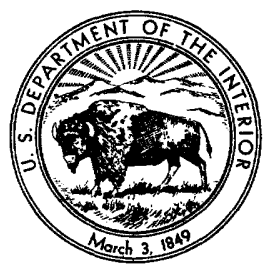




\section{UNITED STATES DEPARTMENT OF THE INTERIOR}

STEWART L. UDALL, Secretary

\section{GEOLOGICAL SURVEY}

Thomas B. Nolan, Director

The U.S. Geological Survey Library catalog card for this publication appears after page 236. 


\section{PREFACE}

This report supplements Bulletin No. 7 "Annotated Bibliography on Hydrology (1951-54) and Sedimentation (1950-54)" which was published under the sponsorship of the Subcommittees on Hydrology and Sedimentation, Inter-Agency Committee on Water Resources. Earlier reports, "Annotated Bibliography on Hydrology (1941-50)" published in the Hydrologic Activities series as Bulletin No. 5, June 1952, and "Annotated Bibliography on Sedimentation" published in the Sedimentation series as Bulletin No. 2, Feb. 1950, were compiled and edited under the auspices of subcommittees of the Federal Inter-Agency River Basin Committee (predecessor to the Inter-Agency Committee on Water Resources).

The following agencies, participating on the Subcommittees on Hydrology and Sedimentation, Inter-Agency Committee on Water Resources, furnished for this bibliography annotated entries for articles and reports published by their respective agencies and for selected papers written by their personnel but published elsewhere:

Department of Agriculture

Agricultural Research Service

Forest Service

Soil Conservation Service

Department of Defense

Corps of Engineers

U.S. Army

Department of Commerce

Bureau of Public Roads

Coast and Geodetic Survey

Weather Bureau

Department of Interior

Bureau of Mines

Bureau of Reclamation

Geological Survey

Department of Health, Education and Welfare

Public Health Service

Federal Power Commission

Tennessee Valley Authority 


\section{CONTENTS}

Page

Preface . .

Introduction

List of sources $\ldots \ldots \ldots 2$

Bibliography $\ldots \ldots$

Index 223 


\title{
ANNOTATED BIBLIOGRAPHY ON HYDROLOGY AND SEDIMENTATION, UNITED STATES AND CANADA
}

\section{5-58}

\author{
Compiled by H. C. Rigas
}

\section{INTRODUCTION}

This publication contains a selected list of papers, articles, and books which were published in the period 1955 through 1958 in the United States and Canada. Every effort has been made to include all listings of significant technical value in the fields of hydrology and sedimentation. In addition to articles on those primary subjects it cites articles in the fields of the many allied sciences. The compilation is largely the result of a shelf-by-shelf search of several large libraries with the decision as to inclusion of articles resting with the compiler.

The bibliography includes entries of data compilations and data reports which are not part of a regular series, such as the annual surfacewater reports of the Geological Survey or the monthly and annual climatological reports of the Weather Bureau. The bibliography does not include articles on construction of water-resources developments, articles describing methods of making chemical and biochemical water analyses, articles of local interest only, or articles in a semipopular style which report the findings given in other papers. Many periodicals having limited distribution and directed toward nontechnical readers were not searched. Theses and other reports having very limited circulation are not included. The cooperative reports issued by the U.S. Soil Conservation Service each winter for major Western river basins and titled "Water Supply Outlook" were not included as their subject matter was not pertinent.

Annotations are brief and are intended only to indicate to the reader whether or not the article referred to might furnish information of the type sought. A few articles are not annotated, either because the article was not available or because the title adequately described the article.

Listings are arranged alphabetically by author, followed by a combined subject and geographic location or river-basin index. Each article is indexed by primary subject, and by geographic area if applicable. Some articles are also indexed by secondary subjects. The smallest geographic areas listed in the index are States and Provinces or river basins. 


\section{LIST OF SOURCES}

Agr. Eng.-Agricultural Engineering Agronomy Jour.-Agronomy Journal Ala. Acad. Sci. Jour.-Alabama Academy of Science Journal

Ala. Geol. Survey

Bull.

County Rept.

Inf. Ser.

Spec. Rept.
Alabama Geological Survey

Bulletin

County Report

Information Series

Special Report

Am. Assoc. Adv. Sci.-American Association for the Advancement of Science

Am. Assoc. Petroleum Geologists Bull.-American Association of Petroleum Geologists Bulletin

Am. Fisheries Soc.-American Fisheries Society

Am. Forestry Assoc.-American Forestry Association

Am. Forests-American Forests

Am. Geog. Soc. Dept. Explor. and Field Research-American Geographical Society,

Department of Exploration and Field Research

Am. Geophys. Union Trans.-American Geophysical Union Transactions

Am. Insurance Assoc.--American Insurance Association

Am. Jour. Sci.-American Journal of Science

Am. Meteorol. Mon.-American Meteorological Monographs

Am. Meteorol. Soc. Bull.-American Meteorological Society Bulletin

Am. Meteorol. Soc. Meteorol. Mon.-American Meteorological Society, Meteorological Monographs

Am. Midland Naturalist-American Midland Naturalist

Am. Scientist-American Scientist

Am. Soc. Agr. Engineers-American Society of Agricultural Engineers

Am. Soc. Agr. Engineers Trans.-American Society of Agricultural Engineers Transactions

Am. Soc. Civil Engineers

Proc.

American Society of Civil Engineers

Trans.

Proceedings

Transactions

Am. Soc. Testing Materials Tech. Pub.-American Society for Testing Materials Technical Publication

Am. Soc. Testing Materials Spec. Tech. Pub.-American Society for Testing Materials, Special Technical Publication

Am. Water Works Assoc. Jour.-American Water Works Association Journal

Annals Assoc. Am. Geographers Spec. Publ.-Annals of the Association of American Geographers Special Publication

Arctic

Arctic Inst. North America Spec. Pub.-Arctic Institute of North America Special Publication

Ariz. Agr. Expt. Sta. Bull.-Arizona Agricultural Experiment Station Bulletin

Ariz. Cattlelog-Arizona Cattlelog

Ariz. Land Dept. Water Resources Rept.-Arizona Land Department Water Resources Report

Ariz. Univ. Bull.-Arizona, University of, Bulletin 
Ariz. Univ. Inst. Atmospheric Physics-Arizona, University of, Institute of, Atmospheric Physics

Ariz. Watershed Management Div.-Arizona Watershed Management Division

Ariz. Watershed Program Proc.-Arizona Watershed Program Proceedings

Ark. Agr. Expt. Sta. Bull.-Arkansas Agricultural Experiment Station Bulletin

Ark. Geol. and Conserv. Comm. Water Resources Circ.-Arkansas Geological and Conservation Commission Water Resources Circular

Ark. Univ. Eng. Expt. Sta. Bull.--Arkansas, University of, Engineering Experiment Station Bulletin

Ark. Water Study Comm.--Arkansas Water Study Commission

Atomic Energy in Industry, Natl. Indus. Conf. Board, Inc., 5th Ann. Conf.-Atomic Energy in Industry, National Industrial Conference Board, Inc., 5th Annual Conference

Better Crops with Better Plant Food

Calif. Acad. Sci. Proc.-California Academy of Science Proceedings

Calif. Agr. Expt. Sta.-California Agricultural Experiment Station

Calif. Dept. Water Resources

Bull.

California Department of Water Resources

Rept.

Bulletin

Report

Calif. Disaster Office-California Disaster Office

Calif. Div. Resources Plan. Bull.-California Division of Resources Planning Bulletin

Calif. Div. Water Resources

Bull.

California Division of Water Resources

Water Quality Inventory Rept.

Bulletin

Water Quality Inventory Report

Calif. Inst. Technology Sedimentation Lab. Rept.-California Institute of Technology Sedimentation Laboratory Report

Calif. Law Rev.-California Law Review

Calif. State Water Resources Board Bull.--California State Water Resources Board Bulletin

Calif. Univ.

Comm. Research Water Resources

California, University of

Committee on Research in Water Resources

Inst. Eng. Research

Water Resources Center

Wave Research Lab.

Institute of Engineering Research

Water Resources Center

Wave Research Laboratory

Calif. Water Pollution Control Board Pub.-California Water Pollution Control Board Publication

Calif. Water Proj. Authority Rept.-California Water Project Authority Report

Canada Dept. Agr.-Canada Department of Agriculture; Experimental Farms Service

Canadian Jour. Agr. Sci--Canadian Journal of Agricultural Science

Canadian Jour. Soil Sci.-Canadian Journal of Soil Science

Canadian Jour. Technology-Canadian Journal of Technology

Chemical and Engineering News

Chicago Univ. Dept. Geography Research Paper-Chicago, University of, Department of Geography Research Paper

Chicago Univ. Law School-Chicago, University of, Law School

Civil Engineering

Colo. A. and M. Coll., Agr. Expt. Sta. Tech. Bull.-Colorado A. and M. College, Agricultural Experiment Station Technical Bulletin

Colo. Agr. Expt. Sta. Paper-Colorado Agricultural Experiment Station Paper

Colo. State Univ. Dept. Civil Eng.-Colorado State University Department of Civil Engineering 
Colo. State Univ. Expt. Sta. Tech. Bull.-Colorado State University Experiment Station Techniral Bulletin

Colo. Water Conserv. Board-Colorado Water Conservation Board

Columbia Univ. Dept. Geology Tech. Rept.-Columbia University Department of Geology Technical Report

Conf. Quality Water Irrig.-Conference on Quality of Water for Irrigation

Cong. Internat. Comm. Irrig. and Drainage-Congress of International Commission on Irrigation and Drainage

Conn. Agr. Expt. Sta. Bull.-Connecticut Agricultural Experiment Station Bulletin

Conn. Soc. Civil Engineers-Connecticut Society of Civil Engineers

Conn. Water Resources Comm.--Connecticut Water Resources Commission

Council State Govts.--Council of State Governments

Crops and Soils

Del. Agr. Expt. Sta.-Delaware Agricultural Experiment Station

Del. Eng. Expt. Sta. Bull.-Delaware Engineering Experiment Station Bulletin

Del. Geol. Survey Bull.-Delaware Geological Survey Bulletin

Del. Geol. Survey Rept. Inv.-Delaware Geological Survey Report of Investigations

Delaware-Lehigh Experimental Forest, Pa. Dept. Forests and Waters-Delaware-

Lehigh Experimental Forest, Pennsylvania Department of Forests and Waters

Eastern Snow Conf. Proc.-Eastern Snow Conference Proceedings

Ecology

Econ. Geography--Economic Geography

Econ. Geology-Economic Geology

Edison Elec. Inst. Bull.-Edison Electric Institute Bulletin

Electronics

Eng. and Mining Jour.-Engineering and Mining Journal

Eng. Jour.-The Engineering Journal

Eng. News-Rec.-Engineering News-Record

Eng. Prog. Univ. Fla.-Engineering Progress at University of Florida

Farm and Ranch

Fla. Dept. Water Resources Memo. Rept.-Florida Department of Water Resources Memorandum Report

Fla. Div. Water Survey and Research Paper-Florida Division of Water Survey and Research Paper

Fla. Geol. Survey

Cire.

Inf. Circ.

Rept.

Rept. Inv.

Florida Geological Survey

Circular

Information Circular

Report

Report of Investigations

Fla. State Univ. Studies-Florida State University Studies

Fla. Univ. Eng. and Indus. Expt. Sta.-Florida University Engineering and Industrial Experiment Station

Fla. Univ. Public Adm. Clearing Service-Florida, University of, Public Administration Clearing Service

Fla. Water Resources Study Comm. Rept.-Florida Water Resources Study Commission Report

Forest Farmer

Forest Notes

Forest Sci.-Forest Science

Fortune

Four States Irrig. Council-Four States Irrigation Council

Ga. Acad. Sci. Bull.-Georgia Academy of Science Bulletin

Ga. Dept. Mines, Mining, and Geology Bull.-Georgia Department of Mines, Mining, and Geology Bulletin 
Ga. Dept. Mines, Mining, and Geology Inf. Circ.-Georgia Department of Mines, Mining, and Geology Information Circular

Ga. Eng. Expt. Sta. Spec. Rept.-Georgia Engineering Experiment Station Special Report

Ga. Mineral Newsletter-Georgia Mineral Newsletter

Ga. Univ. Inst. Law and Govt. Pub.-Georgia, University of, Institute of Law and Government Publication

Ga. Water Use and Conserv. Comm. Rept.-Georgia Water Use and Conservation Commission Report

Geog. Rev.-Geographical Review

Geol. Soc. America Bull.-Geological Society of America Bulletin

Haynes Foundation

Hilgardia

Idaho Bur. Mines and Geology Pamph.--Idaho Bureau of Mines and Geology Pamphlet

Idaho Dept. Reclamation-Idaho Department of Reclamation

Ill. Div. Waterways Pub.-Illinois Division of Waterways Publication

I11. Geol. Survey

Circ.

Rept.

Rept. Inv.

Repr. Ser.

Ill. Water Survey

Bull.

Circ.

Illinois Geological Survey

Circular

Report

Rept. Inv.

Report of Investigation

Reprint Series

Illinois Water Survey

Bulletin

Circular

Ill. Water Survey Div. Circ.-Illinois Water Survey Division Circular

IIl. Water Survey Div. Rept.--Illinois Water Survey Division Report

Ind. Div. Water Resources Bull.-Indiana Division of Water Resources Bulletin

Ind. Water Resources Study Comm.--Indiana Water Resources Study Committee

Indus. Photography--Industrial Photography

Indus. and Eng. Chemistry-Industrial and Engineering Chemistry

Inter-Agency Comm. Land Subsidence in San Joaquin Valley-Inter-Agency Committee on Land Subsidence in San Joaquin Valley

Internat. Comm. Irrig. and Drainage-International Commission on Irrigation and Drainage

Interstate Comm. Potomac River Basin-Interstate Commission on Potomac River Basin

Iowa Agr. Expt. Sta. Bull.-Iowa Agricultural Experiment Station Bulletin

Iowa Geol. Survey Water Supply Bull.-Iowa Geological Survey Water Supply Bulletin

Iowa Inst. Hydraulic Research-Iowa Institute of Hydraulic Research

Iowa Nat. Resources Council Bull.-Iowa Natural Resources Council Bulletin

Johns Hopkins Univ., Chesapeake Bay Inst. Tech. Rept.-Johns Hopkins University, Chesapeake Bay Institute Technical Report

Jour. Farm Economics-Journal of Farm Economics

Jour. Forestry-Journal of Forestry

Jour. Geology-Journal of Geology

Jour. Glaciology-Journal of Glaciology

Jour. Marine Research-Journal of Marine Research

Jour. Meteorology-Journal of Meteorology 
Jour. Range Management-Journal of Range Management

Jour. Soil and Water Conserv.--Journal of Soil and Water Conservation

Kans. Div. Water Resources-Kansas Division of Water Resources

Kans. Geol. Survey Bull.-Kansas Geological Survey Bulletin

Kans. Geol. Survey Rept.-Kansas Geological Survey Report

Kans. Univ. Law Rev.-Kansas, University of, Law Review

Kans. Water Resources Board

Bull.

Pub.

Water Plan Study

Kansas Water Resources Board

Bulletin

Publication

Water Plan Study

Kans. Water Resources Fact-Finding and Research Comm.-Kansas Water Resources Fact-Finding and Research Committee

Ky. Dept. Econ. Devel.--Kentucky Department of Economic Development

Ky. Dept. Econ. Devel. Rept.--Kentucky Department of Economic Development Report

Ky. Eng. Expt. Sta. Bull.-Kentucky Engineering Experiment Station Bulletin

Ky. Gen. Assembly-Kentucky General Assembly

La. Dept. Public Works Pub.-Louisiana Department of Public Works Publication

La. Eng. Expt. Sta. Bull.-Louisiana Engineering Experiment Station Bulletin

La. Geol. Survey Pamph.-Louisiana Geological Survey Pamphlet

La. Geol. Survey Water Resources Pamph.-Louisiana Geological Survey Water Resources Pamphlet

La. Legislative Council-Louisiana Legislative Council

Lab. Climatology, Pubs. Climatology-Laboratory of Climatology, Publications in Climatology

Land and Water

Land Improvement

Law and Contemporary Problems

League Women Voters U.S.-League of Women Voters of the United States

McGill Univ. Sub-Arctic Research Paper-McGill University Sub-Arctic Research Paper

Mass. Senate Doc.-Massachusetts Senate Document

Md. Dept. Geology, Mines and Water Resources Bull.--Maryland Department of Geology, Mines and Water Resources Bulletin

Md. Univ. Bur. Business and Econ. Research-Maryland, University of, Bureau of Business and Economic Research

Meteorol. Abstracts and Bibliography-Meteorological Abstracts and Bibliography

Miami Univ., Marine Lab.-Miami, University of, The Marine Laboratory

Mich. Agr. Expt. Sta. Bull.-Michigan Agricultural Experiment Station Bulletin

Mich. Geol. Survey Div. Rept.-Michigan Geological Survey Division Report

Mich. State Univ., Dept. Resources Devel. Water Bull.-Michigan State University, Department of Resource Development Water Bulletin

Mich. Univ., Inst. Great Lakes Research-Michigan, University of, Institute of Great Lakes Research

Mich. Water Resources Comm.-Michigan Water Resources Commission

Mil. Engineer-Military Engineer

Minn. Agr. Expt. Sta. Bull.-Minnesota Agricultural Experiment Station Bulletin

Minn. Div. Waters Bull.-Minnesota Division of Waters Bulletin

Minn. Div. Waters Tech. Paper-Minnesota Division of Waters Technical Paper

Miss. Board Water Commissioners Bull.-Mississippi Board of Water Commissioners Bulletin

Miss. Farm Research-Mississippi Farm Research

Miss. Geol. Survey Bull.-Mississippi Geological Survey Bulletin

Miss. Water Resources Policy Comm.-Mississippi Water Resources Policy Commission 
Mo. Univ. Agr. Expt. Sta. Bull.-Missouri, University of, Agricultural Experiment Station Bulletin

Mo. Univ. Bull.-Missouri, University of, Bulletin

Mont. Agr. Expt. Sta. Bull.-Montana Agricultural Experiment Station Bulletin

Mont. Bur. Mines and Geology Inf. Circ.-Montana Bureau of Mines and Geology Information Circular

Mont. State Coll., Ext. Service Bull.-Montana State College, Extension Service Bulletin

Mont. State Engineer-Montana State Engineer

Mont. State Univ., 2d Ann. Water Resources Conf. Proc.-Montana State University, 2d Annual Water Resources Conference Proceedings

Monthly Weather Rev.-Monthly Weather Review

N.C. Agr. Expt. Sta. Tech. Bull.-North Carolina Agricultural Experiment Station Technical Bulletin

N.C. Board Health-North Carolina Board of Health

N.C. Board Water Commissioners-North Carolina Board of Water Commissioners

N.C. Dept. Conserv. and Devel. Pub.-North Carolina Department of Conservation and Development Publication

N.C. Div. Mineral Resources Bull.-North Carolina Division of Mineral Resources Bulletin

N.C. Div. Water Resources, Inlets, and Coastal Waterways-North Carolina Division of Water Resources, Inlets, and Coastal Waterways

N.C. State Coll., Dept. Eng. Research, Bull.-North Carolina State College, Department of Engineering Research, Bulletin

N. Dak. Geol. Survey Ground-Water Studies-North Dakota Geological Survey Ground-Water Studies

N. Dak. Water Conserv. Comm.-North Dakota Water Conservation Commission

N.H. Univ. Agr. Expt. Sta. Tech. Bull.-New Hampshire, University of, Agricultural Experiment Station Technical Bulletin

N.H. Univ. Ext. Folder-New Hampshire, University of, Extension Folder

N.J. Div. Water Policy and Supply Spec. Rept.-New Jersey Division of Water Policy and Supply Special Report

N. Mex. Bur. Mines and Mineral Resources Ground-Water Rept.-New Mexico Bureau of Mines and Mineral Resources Ground-Water Report

N. Mex. Bur. Mines and Mineral Resources Mem.--New Mexico Bureau of Mines and Mineral Resources Memoir

N. Mex. Inst. Mining and Mineral Resources Circ.-New Mexico Institute of Mining and Mineral Resources Circular

N. Mex. State Engineer Tech. Rept.-New Mexico State Engineer Technical Report

N. Mex. Water Conf. Proc.-New Mexico Water Conference Proceedings

N.Y. Acad. Sci. Trans.-New York Academy of Science Transactions

N.Y. State Joínt Legislative Comm. Natural Resources-New York State Joint Legislative Committee on Natural Resources

N.Y. State Mus. and Sci. Service Bull.-New York State Museum and Science Service Bulletin

N.Y. Water Power and Control Comm. Bull.-New York Water Power and Control Commission Bulletin

Natl. Research Council, Canada, Bldg. Note--National Research Council, Canada, Building Note

Natl. Water Resources Inst. Proc.-National Water Resources Institute Proceedings

Nebr. Dept. Roads and Irrig. Rept.-Nebraska Department of Roads and Irrigation Report

Nebr. Geol. Survey Bull.-Nebraska Geological Survey Bulletin 
Nebr. Univ. Conserv. and Survey Div. Pub. Suppl.-Nebraska, University of, Conservation and Survey Division Publication Supplement

Nebr. Univ.-Nebraska, University of

Nev. Agr. Expt. Sta. Bull.-Nevada Agricultural Experiment Station Bulletin

Nev. State Engineer Bull.-Nevada State Engineer Bulletin

New England Water Works Assoc. Jour.-New England Water Works Association Journal

Northeastern Logger

Northwest Sci.--Northwest Science

Ohio Agr. Expt. Sta. Tech. Bull.-Ohio Agricultural Experiment Station Technical Bulletin

Ohio Div. Water

Bull.

Inf. Circ.

Ohio Division of Water

Bulletin

Information Circular

Ohio Jour. Sci.-Ohio Journal of Science

Ohio Legislative Service Comm. Research Rept.-Ohio Legislative Service Commission Research Report

Ohio River Valley Water Sanitation Comm.-Ohio River Valley Water Sanitation Commission

Ohio State Univ. Eng. Expt. Sta. Circ.-Ohio State University Engineering Experiment Station Circular

Ohio State Univ. Studies, Eng. Ser.-Ohio State University Studies, Engineering Series

Okla. Agr. Expt. Sta. Circ.--Oklahoma Agricultural Experiment Station Circular

Okla. Div. Water Resources Pub.--Oklahoma Division of Water Resources Publication

Okla. Geol. Survey Bull.-Oklahoma Geological Survey Bulletin

Okla. Univ.-Oklahoma, University of

Oreg. Water Resources Board Bull.-Oregon Water Resources Board Bulletin

Pa. Dept. Forests and Waters Rept.-Pennsylvania Department of Forests and Waters Report

Pa. Forests-Pennsylvania Forests

Pa. State Univ.--Pennsylvania State University

Pa. Topog. and Geologic Survey Pennsylvania Topographic and Geologic Survey

Bull.

Bulletin

Inf. Circ.

Information Circular

Prog. Rept.

Progress Report

Pacific Sci.-Pacific Science

Pacific Southwest Inter-Agency Comm. Minutes-Pacific Southwest Inter-Agency Committee Minutes

Pecos River Comm.-Pecos River Commission

Photogramm. Eng.--Photogrammetric Engineering

Plant Food Review

Prism, Colo. State Univ.-The Prism, Colorado State University

Public Administration Service Rept.-Public Administration Service Report

Public Health Repts.-Public Health Reports

R.I. Devel. Council Geol. Bull.-Rhode Island Development Council Geologic Bulletin

Reclamation Era

Resources For The Future, Inc. 
Rocky Mtn. Forest Expt. Sta. Paper-Rocky Mountain Forest Experiment Station Paper

Rocky Mtn. Hydraulic Lab. Rept.-Rocky Mountain Hydraulic Laboratory Report Royal Soc. Canada Trans.-Royal Society of Canada Transactions

Rural New Yorker

S. Dak. Geol. Survey Rept.-South Dakota Geological Survey Report

S. Dak. Geol. Survey Rept. Inv.-South Dakota Geological Survey Report of Investigation

Sci.-Science.

Sci. Am.-Scientific American

Sci. Monthly-Scientific Monthly

Seventh Weather Radar Conf. Proc.-Seventh Weather Radar Conference Proceedings

Sewage and Indus. Wastes-Sewage and Industrial Wastes

Smithsonian Inst. Pub.-Smithsonian Institution Publication

Soc. Am. Foresters Proc.-Society of American Foresters Proceedings

Soil and Water

Soil Conserv.-Soil Conservation

Soil Sci.--Soil Science

Soil Sci. Soc. Am. Proc.-Soil Science Society of America Proceedings

Spec. Comm. Study Water Resources Md.-The Special Commission to Study the Water Resources in Maryland

Tenn. Div. Geology Bull.-Tennessee Division of Geology Bulletin

Tenn. Div. Geology Rept. Inv.-Tennessee Division of Geology Report of Investigation

Tenn. Div. Water Resources-Tennessee Division of Water Resources

Texas A. and M. Coll.-Texas Agricultural and Mechanical College

Texa, A. and M. Research Found.-Texas Agricultural and Mechanical Research Foundation

Texas Board Water Engineers Bull.-Texas Board of Water Engineers Bulletin

Texas Board Water Engineers-Texas Board of Water Engineers

Texas Univ. Bur. Eng. Research-Texas University Bureau of Engineering Research

Texas Soc. Prof. Engineers Pub.-Texas Society of Professional Engineers Publication

Texas Univ. School of Law-Texas, University of, School of Law

United Fresh Fruit and Vegetable Association, 1958 Yearbook

U.N. Dept. Econ. and Social Affairs Rept.-United Nations Department of Economic and Social Affairs Report

U.N. Econ. Comm. for Asia and Far East, Manual River Basin Plan.-United Nations Economic Commission for Asia, and the Far East, Manual of River Basin Planning

U.N. Rev.-United Nations Review

U.S. Agr. Research Service-U.S. Agricultural Research Service

U.S. Army Corps Engineers

Comm. on Tidal Hydraulics Tech. Bull.

Jacksonville Dist.

Mississippi River Div.

Missouri River Div.

North Pacific Div.

Ohio River Div.

Sacramento Dist.

Seattle

South Pacific Div.
U.S. Army Corps of Engineers

Committee on Tidal Hydraulics Technical Bulletin

Jacksonville District

Mississippi River Division

Missouri River Division

North Pacific Division

Ohio River Division

Sacramento District

Seattle

South Pacific Division 


\section{U.S. Army Corps Engineers (Cont'd.) \\ Tulsa Dist. \\ Washington Dist. \\ Waterways Expt. Sta.
U.S. Army Corps of Engineers (Cont'd.)
Tulsa District
Washington District
Waterways Experimental Station

U.S. Army Reserve 5002d Research and Development Unit Interim Report

U.S. Beach Erosion Board Tech. Memo.-U.S. Beach Erosion Board Technical Memorandum

U.S. Bur. Mines Rept. Inv.--U.S. Bureau of Mines Report of Investigations

U.S. Bur. Reclamation

Chem. Eng. Lab. Rept.

Comm. Office

Div. Proj. Inv.

Hydraulic Lab. Rept.

Sed. Sec.
U.S. Bureau of Reclamation

Chemical Engineering Laboratory Report

Commissioner's Office

Division of Project Investigations

Hydraulic Laboratory Report

Sediment Section

U.S. Chamber Commerce-U.S. Chamber of Commerce

U.S. Dept. Agriculture

Bull.

Farmer's Bull.

Handb.

Tech. Bull.

Yearbook
U.S. Department of Agriculture

Bulletin

Farmer's Bulletin

Handbook

Technical Bulletin

Yearbook

U.S. Dept. Agr., Soil Conserv. Service-U.S. Department of Agriculture, Soil Conservation Service

U.S. Dept. Army Tech. Bull.--U.S. Department of the Army Technical Bulletin

U.S. Dept. Interior-U.S. Department of Interior

U.S. 85th Cong., Senate Docs.--U.S. 85th Congress, Senate Documents

U.S. Federal Power Comm.--U.S. Federal Power Commission

U.S. Fish and Wildlife Service Circ.-U.S. Fish and Wildlife Service Circular

U.S. Fish and Wildlife Service Spec. Sci. Rept.-U.S. Fish and Wildlife Service Special Scientific Report

U.S. Forest Service

Calif. Forest and Range Expt. Sta.

Intermountain Forest and Range Expt. Sta.

Lake States Forest Expt. Sta.

Northeastern Forest Expt. Sta.

Pacific Northwest Forest and

Range Expt. Sta.

Southeastern Forest Expt. Sta.

Southern Forest Expt. Sta.

Watershed Management Conf. Northern Region Proc.

U.S. Geol. Survey

Circ.

Prof. Paper

Water-Supply Paper

U.S. Forest Service

California Forest and Range Experiment Station

Intermountain Forest and Range Experiment Station

Lake States Forest Experiment Station

Northeastern Forest Experiment Station

Pacific Northwest Forest and Range Experiment Station

Southeastern Forest Experiment Station

Southern Forest Experiment Station

Watershed Management Conference Northern Region Proceedings

U.S. Geological Survey

Circular

Professional Paper

Water-Supply Paper

U.S. Indus. Coll. Armed Forces--U.S. Industrial College of the Armed Forces

U.S. Inter-Agency Comm. Water Resources Sedimentation Bull.-U.S. Inter-Agency Committee on Water Resources Sedimentation Bulletin 
U.S. OQG Environmental Protection Tech. Rept.-U.S. Office of the Quartermaster General Environmental Protection Technical Report

U.S. SIPRE Research Rept.-U.S. Snow, Ice and Permafrost Research Establishment Research Report

U.S. Soil Conserv. Service-U.S. Soil Conservation Service

U.S. TVA Tech. Mon.-U.S. Tennessee Valley Authority Technical Monograph

U.S. Weather Bur.

Natl. Hurricane Research

U.S. Weather Bureau

Proj. Rept.

Research Paper

Tech. Paper

National Hurricane Research Project Report

Research Paper

Technical Paper

Utah Acad. Sci., Arts, and Letters-Utah Academy of Science, Arts, and Letters

Utah State Agr. Coll. Bull.--Utah State Agricultural College Bulletin

Utah State Engineer Tech. Pub.-Utah State Engineer Technical Publication

Utah State Expt. Sta., Farm and Home Sci.-Utah State Experiment Station, Farm and Home Science

Utah State Univ. Agr. Expt. Sta. Circ.-Utah State University Agricultural Experiment Station Circular

Utah State Univ., Mon. Ser.-Utah State University, Monograph Series

Va. Advisory Legislative Council-Virginia Advisory Legislative Council

Va. Agr. Expt. Sta. Tech. Paper-Virginia Agricultural Experiment Station Technical Paper

Va. Div. Geology Bull.-Virginia Division of Geology Bulletin

Va. Div. Geology Mineral Resources Circ.-Virginia Division of Geology Mineral Resources Circular

Va. Legislative Council-Virginia Legislative Council

Va. Polytech. Inst. Eng. Expt. Sta. Ser.-Virginia Polytechnical Institute Engineering Experiment Station Series

Vt. Agr. Expt. Sta. Bull.-Vermont Agricultural Experiment Station Bulletin

W. Va. Geol. and Econ. Survey Bull.-West Virginia Geological and Economic Survey Bulletin

W. Va. Geol. and Econ. Survey Rept. Inv.-West Virginia Geological and Economic Survey Report of Investigations

Wash. Agr. Expt. Sta. Bull.-Washington Agricultural Experiment Station Bulletin

Wash. Dept. Conserv. and Devel. Water-Supply Bull.-Washington Department of Conservation and Development Water-Supply Bulletin

Wash. State. Coll.-Washington State College

Wash. Univ. [Seattle] Dept. Oceanography Tech. Rept.-Washington, University of, Department of Oceanography Technical Report

Wash. Univ. [Seattle] Inst. Internat. Affairs-Washington, University of, Institute of International Affairs

Washington Acad. Sci. Jour.-Washington Academy of Science Journal

Water and Sewage Works

Water Resources Council, Highway Research Board Bull.-Water Resources Council, Highway Research Board Bulletin

Water Well Jour.-Water Well Journal

Water Works Eng.-Water Works Engineering

Weatherwise

Western Assoc. State Game and Fisheries Comm. Ann. Conf. Proc.-Western Association of State Game and Fisheries Commissioners Annual Conference Proceedings

Western Conserv. Jour.-Western Conservation Journal

Western Snow Conf. Proc.--Western Snow Conference Proceedings 
Wis. Geol. and Nat. History Survey Circ.-Wisconsin Geological and Natural History Survey Circular

Wis. Univ. Dept. Meteorology Rept.-Wisconsin, University of, Department of Meteorology Report

Woods Hole Oceanographic Institution

Wyo. Geol. Survey Rept. Inv.-Wyoming Geological Survey Report of Investigations Wyo. Nat. Resource Board-Wyoming Natural Resource Board

Wyo. Univ. Agr. Expt. Sta. Mimeo. Circ.-Wyoming, University of, Agricultural Experiment Station Mimeographed Circular 


\section{BIBLIOGRAPHY}

\section{Aandahl, Fred G.}

The nation's water resources: Am. Water Works Assoc. Jour., v. 48, no. 8, p. 931-941, 1956.

Resources, requirements, and methods of meeting new demands are discussed.

Abd-Eir-Samie, Ahmed G.

(and Marsh, Albert W.). A tube containing gypsum blocks for following moisture changes in undisturbed soil: Soil Sci. Soc. America Proc., v. 19, no. 4, p. 404-406, 1955.

Gypsum blocks were east in tubes at 6-inch intervals and were tested and found satisfactory. Advantages are ease of installation and intimate contact with undisturbed soil.

Ackermann, William C.

1. On doing watershed research: Soil Conserv., v. 20, no. 8, p. 189-190, 1955.

An explanation is given.

2. (and Colman, E. A., and Ogrosky, Harold O.). From ocean to sky to land to ocean, in U. S. Department of Agriculture, Water: Yearbook of Agriculture 1955 , p. $41-51$.

A description of the hydrologic cycle is presented.

3. Needed research in sedimentation: Am. Geophys. Union Trans., v. 38, p. 925$927,1957$.

Research needs to be greatly expanded, particularly in mechanics of sedimentation, channel stability, and measurement techniques. (Discussion by G. C. Amstutz, and author's closure, v. 39, p. 1159-1160, 1958.)

4. Development and use of the potential water resources of Illinois: Am. Water Works Assoc. Jour., v. 50, no. 8, p. 991-996, 1958.

Potential water resources, Illinois water law, and positive development factors are given.

Adams, H. W.

1. Economic aspects of flood plain zoning: Am. Soc. Civil Engineers Proc., v. 82, no. HY 1, Paper 882, 5 p., 1956.

The economic aspects of zoning cited in the paper make it essentially an alternative to evacuation or to prevention. (Discussion by H. Alden Foster, v. 82, no. HY 1, Paper 881, p. 63-64, 1956.)

2. Pumping requirements for leveed agricultural areas: Am. Soc. Civil Engineers Proc., v. 83, no. IR 1, Paper 1236, 23 p., 1957.

A method is presented for determining the optimum pumping capacity requirements for stations serving leveed agricultural areas. Hydrologic and economic factors are considered. (Discussion by Gordon R. Williams, v. 83, no. IR 2, Paper 1377, p. 3-4, 1957, and author's closure, v. 84, no. IR 2, Paper 1615, p. 3-4, 1958.)

Adams, John E.

(and Kirkham, Don, and Nielsen, Donald R.). A portable rainfall-simulator infiltrometer and physical measurements of soil in place: Soil Sci. Soc. America Proc., v. 21, no. 5, p. 473-477, 1957. 
The instrument is driven into the soil and delivers rainfall over a circular area $5 \frac{3}{4}$ inches in diameter. Infiltration and wash erosion data can be obtained in 30 minutes.

Adams, Mark F.

Water resources of the State of Washington: Wash. State Coll., 1 v., 1956.

Adams, Robert M. See Jacobsen, T.

Advisory Commitree on Weather Control.

Final report of the Advisory Committee on Weather Control: Washington, U.S. Govt. Printing Office, v. 2, 1957.

Volume 1 contains the Committee's findings and recommendations, and volume 2 contains detailed technical reports which in part form the basis for the findings and recommendations.

Ahmad, Mushtaq. See Neville, J. F.

Ahmad, Nazir. See Petersen, J. S.

Albert, Frank A.

(and Spector, Albert H.). A new song on the muddy Chattahoochee, in U.S.

Department of Agriculture, Water: Yearbook of Agriculture 1955, p. 205-210.

Average turbidity of Chattahoochee River has declined greatly since 1931 . The decline is attributed to improved land-use practices.

Albertson, Maurice L. See Benedict, P. C., 1; Laursen, E. M., 1; Liu, H. K., 1; Mostafa, M. G.; Petersen, J. S.

Alexander, G. N. See Foster, H. A., 1; Kuiper, E.; Langbein, W. B., 6; Moran, P. A. P.; Potter, W. D., 2.

Alexander, J. C. See Critchlow, H. T.

Alexander, L. J. See Bergen, S. W.

Allen, Bruce F. See Morris, S. B., 1.

Allen, F. C.

(and Glover, R. E., Garstka, W. U., and Posz, H. M.). Heated precipitation-gage

intake tube: Am. Geophys. Union Trans., v. 36, p. 311-314, 1955.

The design and function of the tube are described. (Discussion by Richard D. Tarble, v. 37, p. 330-331, 1956.)

Allen, Geary M., Jr. See Carter, R. H., Jr.

Allen, Shirley W.

Conserving natural resources: New York, McGraw-Hill Book Co., 347 p., 1955.

This book, intended as a college text, emphasizes the social responsibilities of owners of natural resources. Inexhaustible natural resources, replaceable and maintainable resources, and irreplaceable resources are covered.

Allen, William B.

Ground-water resources of the East Greenwich Quadrangle, Rhode Island: R.I. Devel. Council Geol. Bull., no. 8, 56 p., 1956.

The report contains data on selected wells and test borings, describes the hydrologic characteristics of the water-bearing deposits, summarizes the use of ground water, presents data on the quality of water and the possibilities of salt-water contamination, and discusses the best areas for future development of ground water. 
Allis, John A.

(and Kelly, Ludwig L.). Runoff from small watersheds: Soil Conserv., v. 23, no. 8, p. 164-166, 1958.

A 9-year study of 24 watersheds showed much greater runoff from straight-row-cultivated watersheds than from others.

Allison, F. E.

(and Roller, E. M., and Raney, W. A.). Relationship between evapotranspiration and yields of crops grown in lysimeters receiving natural rainfall: Agronomy Jour., v. 50, no. 9 , p. 506-511, 1958.

Losses of water to the air from cropped lysimeters were greater than from bare soil and were directly correlated with crop yields.

Allison, L. E.

(and Reeve, R. C.). Lysimeters for studying effects of salinity, leaching, and position of water table on plant growth: Soil Sci., v. 79, no. 2, p. 81-91, 1955.

A lysimeter installation is described which has been found useful for studying the effects of salinity and water-table position on plant growth.

Alpert, Leo.

Silver iodide cloud seeding in Puerto Rico: Am. Geophys. Union Trans., v. 36, p. 227-234, 1955.

Few opportunities for cloud seeding with ground generators were observed. Most rain fell from cumulus clouds far below the $-5^{\circ} \mathrm{C}$ level where silver iodide first becomes effective. In some cases, seeding to increase the fall may result in destructive floods. The trade inversion during the dry season forms an effective ceiling to the penetration of silver iodide smoke aloft.

Amein, Amein M.

(and Priest, Melville S.). Free-surface disturbances along a channel wall: Am. Soc. Civil Engineers Proc., v. 82, no. HY 3, Paper 1005, 11 p., 1956.

The initiation and growth of free-surface disturbances along the wall of a steep channel were studied experimentally. Results of the analyses are shown graphically and mathematically. Corrections, v. 82, no. HY 6, Paper 1131, p. 3, 1956.

american Insurance Association.

Studies of floods and flood damage, 1952-55: Am. Insurance Assoc., 293 p., 1956. The traditional position of the Capital Stock Insurance business on the writing of specific flood insurance on fixed-location properties subject to recurrent floods, and studies of floods and flood damage are presented.

American Society for Testing Materials.

1. Symposium on permeability of soils: Am. Soc. Testing Materials, Tech. Pub. no. 163, 136 p., 1955.

Subjects are permeability testing; water movement through porous hydrophilic systems; low-head permeameter for testing granular materials; permeability of compacted fine-grained soils, sand, and sand-gravel mixtures; measurement of hydraulic conductivity of soil in place and of permeabilities in ground-water investigations; and determination of permeability of granular soil by air subjected to a decreasing pressure differential.

2. Manual on industrial water: Am. Soc. Testing Materials Spec. Tech. Pub., no. 148-B, 490 p., 1956.

The report describes uses, composition, treatment, sampling, and analysis of industrial water, and sampling and analysis of waterformed deposits.

3. Symposium on industrial water and industrial waste water: Am. Soc. Testing 
Materials Spec. Tech. Pub., no. 207, 52 p., 1957.

The report contains four papers, with discussion, on waste problems and pollution control.

American Society of Civil Engineers.

1. Variation of point rainfall with distance--progress report of the Sanitary Engineering Research Committee, Water Section: Am. Soc. Civil Engineers Proc., v. 82, no. SA 1, Paper 888, 9 p., 1956.

Variation of point rainfall with distance was studied using data from a 50-gage network within a 100-square mile area in Illinois. The regression method was found most practical for prediction purposes.

2. SED research report no. 9; Evaluation of water resources of a river basin, by the Sanitary Engineering Research Committee, Water Section: Am. Soc. Civil Engineers Proc., v. 82, no. SA 5, Paper 1087, 5 p., 1956.

A method of evaluating the water resources of a river basin is developed and applied to the Neuse River basin, North Carolina.

3. Principles of a sound national water policy-a restatement: Civil Eng., v. 27, p. 52-57, May 1957.

The 1957 report of the Engineers Joint Council Board of Review is presented.

American Society of International Law.

The diversion of Columbia River waters: Wash. Univ. [Seattle] Inst. Internat. Affairs Bull. 12, p. 4, 63 p., 1956.

This report of the proceedings of a meeting of the American Society of International Law contains papers by Canadian and United States lawyers.

American Water Works Association.

1. Instrumentation for radioactive-pollution studies: Am. Water Works Assoc. Jour., v. 48 , no. 4 , p. $397-416,1956$.

The report of a task group is given.

2. Artificial ground water recharge: Am. Water Works Assoc. Jour., v. 48, no. 5, p. 493-498, 1956.

The report of a task group is given.

Amsbary, Frank C., Jr.

(and Foster, John W.). A modern water development in an ancient valley: Water Works Eng., v. 108, no. 6, p. 512-515, 1955.

The discovery of the ancient Mahomet (Teays) Valley in Illinois and its exploitation for water supply are described.

Amstutz, G. C. See Ackermann, W. C., 3.

ANDERs, R. B.

Ground-water geology of Wilson County, Texas: Texas Board of Water Engineers Bull. 5710, 62 p., 1957.

Anders, Robert B. See Peek, H. M., 1.

Anderson, Alvin G. See Straub, L. G., 3.

Anderson, H. Kenneth. See Bethlahmy, N., 2.

Anderson, Harold E.

(and James, George A.). Watershed management and research on salmon streams of southeast Alaska: Jour. Forestry, 55, p. 14-17, Jan. 1957.

Streamflow, stream temperature, streambed and channel changes, sedimentation, and climatological data have been observed on four watersheds, two of which are to be logged after calibration. Logging in one watershed began in 1953. Multipleuse management for timber and salmon is the objective. 
Anderson, Henry W.

1. Detecting hydrologic effects of changes in watershed conditions by double-mass analysis: Am. Geophys. Union Trans., v. 36, p. 199-125, 1955.

Double-mass plotting of hydrologic events against a meteorological control showed marked increases in sedimentation and peak inflow in a California watershed following the wildfires of 1932 and $1933 . \quad$ No change in annual flow was detected.

2. Forest-cover effects on snowpack accumulation and melt, Central Sierra Snow Laboratory: Am. Geophys. Union Trans., v. 37, p. 307-312, 1956.

Water equivalent of the snowpack on Apr. 1 and the melt rate after Apr. 1 were related to the amount of shade from trees to the south and to the amount of shielding from trees to the north of the point. A high degree of association is shown (Discussion by J. E. Church, and author's closure, v. 38, p. 116, 1957.)

3. Relating sediment yield to watershed variables: Am. Geophys. Union Trans., v. 38, p. 921-924, 1957.

This paper summarizes and discusses some recent studies in which multiple-regression analysis was used in relating sediment yield to watershed variables.

4. (and Pagenhart, T. H.). Snow on forest slopes: Western Snow Conf. Proc., p. 19-23, Apr. 1957.

Snowpack water equivalent was related to six terrain and three forest variables. Results should be useful in sampling design.

5. Progress in snow management research in California: Western Snow Conf. Proc., p. 12-21, Apr. 1958.

Studies are described for developing and testing methods of managing the snow zone for improved water yield.

6. (and Rice, R. M., and West, A. J.). Forest shade related to snow accumulation: Western Snow Conf. Proc., p. 21-31, Apr. 1958.

The effects of various forest parameters on snow accumulation and melt were investigated. Results indicate that the ideal forest (one managed for water production) would result from strip cutting.

7. (and Rice, R. M., and West, A. J.). Snow in forest openings and forest stands: Soc. Am. Foresters Proc., p. 46-50, 1958.

Relative amounts of snow accumulation and notes of snow melting in open and forested areas are given.

8. California cooperative snow management research-a progress report, 1957-58:

Calif. Dept. Water Resources, 56 p., 1958.

9. Progress report, 1957-58, cooperative snow management research: U.S. Forest

Service, Calif. Forest and Range Expt. Sta., 56 p., 1958.

Objectives, methods, plans and results of 18 snow management studies in the headwaters of five major California river basins are summarized and indexed. Basic meteorology, snow, sediment, and streamflow data are included.

Anderson, Keith E.

1. Unfailing wells irrigate 64,000 -acre project: Eng. News-Rec., v. 154, no. 16, p. 57-58, Apr. 21, 1955.

The largest single ground-water irrigation project yet built is described.

2. The Soap Lake basin: Am. Soc. Civil Engineers Proc., v. 83, no. IR 2, Paper 1384, 7 p., 1957.

This paper describes the effect of irrigation flows on the inflow-evaporation balance and on the quality of the lake water. 
Anderson, Lois C.

The standard deviation as a measure of variability of monthly mean temperature in the Northern Hemisphere: U.S. OQG Environmental Protection Tech. Rept., no. 16,41 p., 1955.

A series of maps showing standard deviation of monthly mean temperature in the Northern Hemisphere is presented.

Anderson, W. E. See Stockwell, H. J., 1, 4.

Andreasen, Gordon E.

(and Rasmussen, William C.). A hydrologic budget in relation to climate and geology of the Beaverdam Creek basin, Maryland: Washington Acad. Sci. Jour., v. 46 , no. 8, p. 266-267, 1956.

Abundant rainfall is discharged about equally in the form of runoff and by evapotranspiration.

Andrew, A. N. See also Clark, R. H.

Volumetric forecasts of the snow-melt floods of the Lake St. John watershed: Eastern Snow Conf. Proc., v. 3, p. 48-66, 1955.

Water yield of the spring flood is related to accumulated winter precipitation and available ground-water storage.

Andrews, L. A.

(and Broadfoot, W. M.). The San Dimas core sampler: Soil Sci., v. 85, no. 6, p. 297-301, 1958.

The sampler was developed to take cores in deep soils with a minimum of disturbance to either the core or the area being sampled.

AndRews, Roy G.

Aids for determining runoff probability: Agr. Eng., v. 38, no. 3, p. 164-167, 1957. Methods of frequency analysis are explained for the practicing engineer.

Arctic Institute: of North America.

Arctic research: Arctic Inst. North America Spec. Pub., no. 2, 261 p., 1955.

Contains articles by many contributors on the current status of research and some immediate problems in the North America arctic and subarctic. The fields of physical, biological, and social sciences are treated.

Arden, R. S.

(and Milne, J. A. S.). The experience of Ontario Hydro in forecasting runoff in

Ontario: Eastern Snow Conf. Proc., v. 4, p. 105-112, 1957.

Precipitation indexes and water contents of snow are used to forecast runoff.

Arend, John L. See Dils, R. E., 1.

Argraves, Newman E.

Connecticut highways and the 1955 floods: Am. Soc. Civil Engineers Proc., v. 84, no. HW 2, Paper 1621, 9 p., 1958.

Restoration of structures and roads damaged or destroyed in the 1955 floods is described.

Arias, Enrique S.

Runoff forecasting and snow surveying in Chile: Western Snow Conf. Proc., p. 68-69, Apr. 1957.

A general description is given. 


\section{Arizona Untversity.}

Conference on the scientific basis of weather modification: Ariz. Univ. Inst. Atmospheric Physics, 1956.

Paper by H. R. Byers and H. G. Houghton are given in full. The many others are shortened somewhat.

\section{Arizona Water Resources Committee.}

1. Arizona watershed program: Ariz. Watershed Management Div., 69 p., 1957. Proceedings of a meeting of Federal, State, and private agencies contributing to Arizona watershed research and management. Nineteen papers are included.

\section{Arkansas Water Study Commission.}

Water in Arkansas: Ark. Water Study Comm., 55 p., 1956.

A report to the General Assembly of Arkansas on the surface water resources and ways whereby a better balance can be effected between periods of surplus and periods of shortage.

Arkansas-White-Red Basins Inter-Agency Committee.

Development of land and water resources of the Arkansas-White and Red River Basins: U.S. 85th Cong., 1st sess., Senate Doc. 13, 1011 p., 1957.

Part I contains a description of the area; water resources; hydroelectric power; water pollution control; agriculture; fish and wildlife; recreation; mosquito control and allied problems; mineral resources and geology; topographic mapping, geologic mapping, and hydrologic data programs; and conclusions and recommendations. Part II gives water-resources project data.

Armstrong, C. A.

(and Yost, C. B., Jr.). Geology and ground-water resources of the Palomas PlainDendora Valley area, Maricopa and Yuma Counties, Arizona: Ariz. Land Dept. Water Resources Rept., no. 4, 49 p., 1958.

Report of a reconnaissance investigation to determine the geologic and hydrologic characteristics of the area before the development of ground water reached an advanced stage.

Armstrong, C. G. Russelu. See Berry, A. E., 2.

Armstrong, Clarence A. See Criner, J. H.

Army, T. J.

(and Ostle, B.). The association between free-water evaporation and evapotranspiration of spring wheat under the prevailing climatic conditions of the plains area of Montana: Soil Sci. Soc. America Proc., v. 21, no. 5, p. 469-472, 1957.

In a study of 25 years of crop and weather data, evapotranspiration was negatively correlated with free-water evaporation. The results are explained.

Arnow, Ted.

Records of wells in Travis County, Texas: Texas Board of Water Engineers Bull. 5708, 129 p., 1957.

Aronovici, V. S.

Model study of ring infiltrometer performance under low initial soil moisture: Soil Sci. Soc. America Proc., v. 19, no. 1, p. 1-6, 1955.

A glass-faced tank allowed observation of the nature and rate of advance of the wetting front from a ring infiltrometer. The study illustrated the significance of the hydraulic gradient on the observed infiltration velocity, and the relative importance of ring size, ring depth, and profile upon infiltration velocities. 
Ash, A. S.

(and Eichmeier, A. H., Kidder, E. H., and Granger, D. W.). Hydrologic studies of small watersheds in agricultural areas of southern Michigan. Report no. 1, Sloan-Deer Creek basins: Mich. Water Resources Comm. Rept., 77 p., 1958. This report contains detailed information on rainfall intensity, duration, and frequency, and on the resulting runoff characteristics with emphasis on the unusual storm of Aug. 9, 1956.

Ashley, Richard E.

Is our snowfall decreasing?: Eastern Snow Conf. Proc., p. 47-62, 1958.

The last 36 seasons of a 72-year record averaged 2.5 inches less than the first 36 seasons.

Aspin, Norman. See Clark, R. H.

Asselstine, E. S. See also Weld, B. A.

(and Grossman, I. G.). The ground-water resources of Westchester County, New York, Part 1, Records of wells and test holes: N.Y. Water Power and Control Comm. Bull. GW-35, 79 p., 1955.

Ateshian, K. H. See Todd, D. K., 6.

Attoe, Osborne J. See Hays, O. E., 2.

Austin, Pauline M.

Radar observations of storm structure on the micro-meteorological scale: Seventh Weather Radar Conf. Proc., Miami Beach, Fla., Nov. 1958.

Axley, John H. See Lull, H. W., 9.

Axtell, J. D. See Hall, W. A., 5.

Ayers, H. D. See also Witherspoon, D. F., 2.

1. The effect of crop cover on the infiltration characteristics of Guelph loam soil: Canadian Jour. Soil Sci., v. 37, no. 2, p. 128-133, 1957.

Infiltration capacity under grass-legume cover was in excess of 1.6 inches per hour during the first hour but less than 0.8 inch per hour for bare soil.

2. (and Wikramanayake, V. E. A.). The effect of the water-storage capacity of the soil on mass infiltration: Canadian Jour. Soil Sci., v. 38, no. 1, p. 44-48, 1958 .

An equation is defined between mass infiltration for 20 minutes and the available storage capacity in the top 6 inches of soil.

Ayers, JoHn C.

A dynamic height method for the determination of currents in deep lakes: Mich. Univ. Inst. Great Lakes Research Contr. 2, 1957.

The technique, an adaptation of the oceanographer's dynamic height method to fresh-water conditions, appears promising for the study of certain circulation phenomena of large deep lakes.

BabBit, Harold E.

(and Doland, James J.). Water supply engineering: 5th ed., New York, McGrawHill Book Co., 608 p., 1955.

This fifth edition is a revision of a comprehensive text which presents information on the latest accepted practices in the field of water works with emphasis on design.

BABCOCK, H. M.

(and Bjorklund, L. J.). Ground-water geology of parts of Laramie and Albany 
Counties, Wyoming, and Weld County, Colorado, with a section on chemical quality of the ground water, by L. R. Kister: U.S. Geol. Survey Water-Supply Paper 1367, 61 p., 1956.

The area described includes the part of the drainage basins of Crow Creek and Lone Tree Creek that lies upslope from the irrigation canals of the South Platte River irrigation system.

Back, William. See also Matthai, H. F., 3.

Geology and ground-water resources of the Smith River Plain, Del Norte County, California: U.S. Geol. Survey Water-Supply Paper 1254, 73 p., 1957.

This report describes the geography and geology of the area, fluctuations of the water table, the amounts of ground-water storage and use, and the quality of the ground water.

Bacon, Vinton W. See Rawn, A. M.

BADER, Richard G.

(and Paquette, Robert G.). A piston coring device for sediment sampling: Wash. Univ. (Seattle) Dept. Oceanography Tech. Rept., no. 41, 18 p., 1955.

A new piston corer is described which is a modification of the Kullenberg coring tube and which eliminates some of the disadvantages of the latter.

Baer, Ledolph.

Orographic rainfall distribution with application to Hawaii: Am. Geophys. Union

Trans., v. 37, p. 546-548, 1956.

The logarithmic spacing of isohyets on a mountain is discussed and the distribution equation derived.

BAFFA, JoHN J.

Developments in artificial ground water recharge: Am. Water Works Assoc. Jour., v. 50, no. 7, p. 865-871, 1958.

The report of a task group is given.

BAILEY, E. G.

1. Index of surface-water records to September 30, 1955, part 12, Pacific slope basins in Washington and upper Columbia River basin: U.S. Geol. Survey Circ. 392, 24 p., 1956.

An index giving drainage area and period of record is presented.

2. Index of surface-water records to September 30, 1955, part 13, Snake River basin: U.S. Geol. Survey Circ. 393, 19 p., 1956.

An index giving drainage area and period of record is presented.

3. Index of surface-water records to September 30, 1955, part 14, Pacific slope basins in Oregon and lower Columbia River basin: U.S. Geol. Survey Circ. 394, 19 p., 1956.

An index giving drainage area and period of record is presented.

4. Index of surface-water records to September 30, 1955, Hawaii: U.S. Geol. Survey Circ. 395, 12 p., 1956.

An index giving drainage area and period of record is presented.

5. Index of surface-water records to Sept. 30, 1955, Alaska: U.S. Geol. Survey Circ. 396, 10 p., 1956.

An index giving drainage area and period of record is presented.

BAIRD, P. D.

Glaciological research in the Canadian arctic: Arctic, v. 8, no. 2, p. 96-108, 1955.

The extent of the glacierized area and a history of investigations are given. 
Baker, Donald McCord. See Thomas, R. O., 2.

BAKER, J. A.

1. Geology and ground-water resources of the Paintsville area, Kentucky: U.S.

Geol. Survey Water-Supply Paper 1257, 123 p., 1955.

All known wells in the 60-square-mile area were inventoried. Total ground-water use is estimated. The amount of water obtainable from wells in the various formations and its quality are approximated.

2. (and Price, W. E., Jr.). Public and industrial water supplies of the eastern coal field region, Kentucky: U.S. Geol. Survey Circ. 369, 63 p., 1956.

The report contains pumpage, source, and detailed chemical analyses of more than 100 supplies.

BAKER, JACK.

Geology and ground water of the Piedmont area of Alabama: Ala. Geol. Survey Spec. Rept. 23, 99 p., 1957.

A reconnaissance study to determine the occurrence, quality, and movement of ground water was made.

BAKER, R. C.

Arkansas' ground-water resources: Ark. Geol. and Conserv. Comm. Circ. 1, 16 p., 1955.

BaLdwin, Henry I.

The effect of forest on snow cover: Eastern Snow Conf. Proc., v. 4, p. 17-24, 1956.

The literature is reviewed, and observations in New Hampshire are summarized.

Balloffet, Armando. See Thomas, C. W.

Banks, Harvey O. See also Morris, S. B., 1.

1. (and Richter, Raymond, and Harder, James). Sea water intrusion in California:

Am. Water Works Assoc. Jour., v. 49, no. 1, p. 71-88, 1957.

Extent of intrusion, methods of control, previous investigations, and field and laboratory investigational programs are described.

2. Teamwork in the solution of water problems: Am. Soc. Civil Engineers Proc., v. 84, no. IR 1, Paper 1497, 7 p., 1958.

Various aspects of teamwork among agencies, and between professional groups and the public are considered. (Discussion by Alfred R. Golze, v. 84, no. IR 3, Paper 1784, p. 23-25, 1958, and author's closure, v. 85, no. IR 1, Paper 1986, p. 67, 1959.)

3. Statewide water planning: Am. Soc. Civil Engineers Proc., v. 84, no. IR 4, Paper 1861, 8 p., 1958.

The importance of long-range planning of water resource development is examined.

Barker, Franklin B.

1. (and Scott, R. C.). Uranium and radium in the ground waters of the Llano

Estacado, Texas and New Mexico: Am. Geophys. Union Trans., v. 39, p. 459-466, 1958.

Water samples from 47 wells and springs in the Ogallala formation were analyzed for uranium and radium.

2. Factors affecting the transport of radioactivity by water: Am. Water Works Assoc. Jour., v. 50, p. 603-612, 1958.

Movement of radioactive material in ground and surface water is described. Adsorption of radioactivity by mineral particles and uptake by aquatic biota are important factors in surface streams. Results of a study of the ion exchange of certain fission products and natural materials are reported. 
Barksdale, Henry C. See also Bechert, C. H.

1. (and Lang, S. M.). Ground water in the Delaware River Valley: Am. Soc.

Civil Engineers Proc., v. 81, Separate 593, 8 p., 1955.

There are two major geologic subdivisions; one containing productive water-bearing formations, and the other in which aquifers are not suitable for development of large ground-water supplies.

2. (and Greenman, David W., Lang, Solomon M., Hilton, George S., and Outlaw, Donald E.). Ground-water resources of the tri-State region adjacent to the lower Delaware River: N.J. Div. Water Policy and Supply Spec. Rept. 13, 190 p., 1958.

This is an appraisal and evaluation of the availability, quality, use, recharge, and danger of salt-water encroachment.

Barnes, C. A. See Morse, R. M.

Barnes, Carleton P.

What research is doing on problems of water in agriculture in U.S. Department of Agriculture, Water: Yearbook of Agriculture 1955, p. 685-693.

The various possibilities are described.

Barnes, Kenneth K. See also Frevert, R. K.

(and Johnson, H. P.). A runoff sampler for large watersheds: Agr. Eng., v. 37, no. 12, p. $813-815,1956$.

The report describes the design and field installation.

Barnes, Leland $\mathrm{H}$.

Flood damage evaluation on Honey Creek, Texas: Jour. Soil and Water Conserv., v. 13 , no. 5 , p. 226-227, 1958.

This paper gives the henefits provided by flood-control structures and land treatment in the spring of 1957 during which period four unusual storms occurred.

Barnett, Aurelius P.

How intense rainfall affects runoff and soil erosion: Agr. Eng., v. 39, no. 11, p. 703-707, 1958.

Easily measured rainfall characteristics were correlated with erosion from 98 intense storms. Use of several factors did not improve prediction results over use of 60 -minute intensity alone.

BARNey, KeIth R.

The 1951 Kansas City flood: Am. Soc. Civil Engineers Proc., v. 81, Paper 839, 9 p., 1955.

A description of the flood, the causes and total amount of damage, and the pattern of rebuilding are given.

BARR, D. I. H. See Niles, T. M.

Barr, George. See Bethlahmy, N., 1.

Barraclough, K. E. See Trimble, G. R., Jr., 3.

Bartell, Shirley Miller.

Water resources of Illinois: Ill. Water Survey Div. Circ. 73, 10 p., 1958.

A nontechnical article.

Bartelli, Lindo J. See Peters, D. B.; Van Doren, C. A.

Bartholomew, R. P.

(and Hinkle, D. A., and Engler, Kyle). Soil and water losses in southwest Arkan- 
sas as influenced by rainfall characteristics and soil management practices: Ark. Agr. Expt. Sta. Bull. 550, 47 p., 1955.

Barton, James R. See Brooks, N. H.

Barton, Manes.

(and Calvin, Lyle D.). Evaluation of cloud-seeding efforts in the Southern Oregon Cascades, 1952-1957: Western Snow Conf. Proc., p. 66-73, Apr. 1958.

Based on regression and isopercentile analyses, small but statistically nonsignificant increases over expected values were found for snow water content, precipitation, and streamflow during the seeded years.

Battan, Louis J. See Braham, R. R., Jr.

Baumann, E. Robert.

(and Cleasby, John L.). Effect of 1952-56 drought on Iowa impounded water supplies: Am. Water Works Assoc. Jour., v. 50, no. 2, p. 233-244, 1958.

A qualitative survey of the drought (the most severe of record in southern Iowa) is presented. Need for more hydrologic data is emphasized and design requirements for Iowa suggested.

Baumann, Paul.

Basin recharge (in Ground water development-a symposium): Am. Soc. Civil Engineers Trans., v. 122, p. 458-473, 1957.

Artificial recharge of ground-water basins in Los Angeles County is described. (Discussion by Robert T. Knapp, Frederick L. Hotes, Norman H. Brooks, James A. Harder, and Charles H. Lee.)

Baumer, William H. See Meyner, R. B.

Bausman, R. O. See Ellis, H. H.

BAver, L. D.

Soil physics: New York, John Wiley and Sons, 489 p., 1956.

The material is presented in 12 chapters dealing with soil as a disperse system, its mechanical composition, soil-water relationships, structure, air, water, irrigation, drainage, temperature, tillage and erosion.

BAY, Roger R.

1. Cutting methods affect snow accumulation and melt in black spruce stands: U.S. Forest Service, Lake States Forest Expt. Sta. Tech. Note 523, 2 p., 1958.

Cutting narrow east-west strips in black spruce resulted in higher total accumulation of snow and a reduced rate of melt in the spring.

2. Forest type affects snowpack: Jour. Soil and Water Conserv., v. 13, no. 3, p. $129-130,1958$.

The relations of snow depth to sampling data and snow-water content to sampling data were defined for a pine plantation and for an aspen-brush stand in Minnesota.

3. Occurrence and depth of frozen soil: Jour. Soil and Water Conserv., v. 13, no. 5, p. 232-233, 1958.

Soil freezing is compared on four different cover conditions typical of northern Minnesota.

Bayne, Charles $K$.

1. Geology and ground-water resources of Sheridan County, Kansas: Kans. Geol. Survey Bull. 116, [Univ. Kans. Pub.], 94 p., 1956.

Geography and geology are described in general and the occurrence, movement, utilization, and chemical character of the ground water are described in some detail. 
2. Geology and ground-water resources of Reno County, Kansas, with a geologic map by O. S. Fent and C. K. Bayne: Kans. Geol. Survey Bull. 120, 130 p., 1956.

Geography and geology are described in general and the occurrence, movement, utilization, and chemical character of the ground water are described in some detail.

Beadle, Buell W.

(and Cruse, Robert R.). Water conservation through control of evaporation:

Am. Water Works Assoc. Jour., v. 49, no. 4, p. 397-404, 1957.

Report on a research project to test the effectiveness of the monomolecular film method is presented.

Beamer, N. H. See Rasmussen, W. C., 5.

Bean, Robert T.

Geology of the Roswell artesian basin, New Mexico, and its relation to the Hondo Reservoir, with a report on effect on artesian aquifer of storage of flood water in Hondo Reservoir, by Charles V. Theis: N. Mex. State Engineer Tech. Rept. 9, 36 p., 1957.

Beard, Leo R. See Childs, E. F.; Whisler, B. A.

Beauchamp, Keith H. See also Quackenbush, T. H.

Potential use of water irrigation in the humid areas: Am. Soc. Civil Engineers Proc., v. 84, no. IR 3, Paper 1750, 14 p., 1958.

Problems of increasing irrigation water demands for offsetting uneven rainfall are presented.

Beaumont, Robert T. See also Work, R. A., 4.

1. Cooperative snow surveys and water supply forecasting: Jour. Soil and Water Conserv., v. 12, no. 3, p. 115-119, 1957.

The report describes snow surveying and the type, reliability, and use of runoff forecasts in the West.

2. A criterion for selection of length of record for a moving arithmetic mean for hydrologic data: Am. Geophys. Union Trans., v. 38, p. 198-200, 1957.

In forecasting runoff, a reliable base period is needed. A method has been derived for defining the best length of this period. (Discussion by T. E. A. van Hylckama, and author's closure, v. 39 , p. 337-338, 1958.)

Beavers, A. H.

Use of density gradients for size distribution analysis: Soil Sci. Soc. America Proc., v. 22, no. 1, p. 12-14, 1958.

The method described is suited for the size distribution analysis of material less than $0.002 \mathrm{~mm}$ in diameter.

Bechert, Charles H. See also Bergen, S. W.; Johnson, W. M.

(and Barksdale, Henry C., Cramer, John W., Morse, Roy W., Davis, Albert R., and Miller, Lynn M.). Trends in water rights legislation: Am. Water Works Assoc. Jour., v. 50, no. 10, p. 1267-1278, 1958.

A panel discussion covering developments in most of the states is presented.

Beckel, D. K. Brown.

Studies on seasonal changes in the temperative gradient of the active layer of soil at Fort Churchill, Manitoba: Arctic, v. 10, no. 3, p. 151-183, 1957.

A summary of results of an investigation at the Defence Research Northern Laboratory is given.

Beetem, W. A. See Simpson, E. S. 


\section{Behlke, Charles E. See Moore, A. M.}

Behrendt, J. See Thiel, E.

Belcher, Paul.

Regional water supply planning for northern Ohio: Am. Water Works Assoc. Jour., v. 47, no. 9, p. 833-836, 1955.

The case against regional development is presented. (Discussion by Wendell $R$. LaDue.)

Beil, Carlos G., R.

Nuclear long-range fallout in surface waters: Am. Soc. Civil Engineers Proc., v. 83, no. SA 5, Paper 1400, 22 p., 1957.

Runoff coefficients of gross fallout beta radioactivity for streams are calculated from measurements. Solubility, sedimentation, and rate of dissipation of long-range fallout are examined.

Bello, Francts.

Forecast for weather control; brighter: Fortune, May 1958, p. 144-147.

Cloud seeding results seem favorable. A possible causal relation between storms and the sun may be modified to affect the weather.

Bender, Milton E., Jr.

Soil moisture content quickly found: Civil Eng., v. 27, p. 82, Oct. 1957.

A simple method is described.

Benedict, Paul C.

1. (and Albertson, Maurice L., and Matejka, Donald Q.). Total sediment load measured in a turbulence flume: Am. Soc. Civil Engineers Trans., v. 120, p. $457-484,1955$.

The velocity of flow and the transportation of the total sediment load in suspension in model and prototype turbulence flumes are given. Resistance to flow of vertical baffles was noted. Samples of total sediment load and bed material were analyzed for particle size. Minor studies of dune movement are included. (Discussion by W. H. Corbett, O. C. Hansen, and W. M. Borland.)

2. Fluvial sediment transportation: Am. Geophys. Union Trans., v. 38, p. 897-902, 1957.

The modes of sediment transport, several related flow parameters, and the problem of total load determinations are discussed. The need for additional research is emphasized.

Bennett, E. F. See Kuder, W. B.

Bennett, Hugh Hammond.

Elements of soil conservation, second edition: New York, McGraw-Hill Book Co., 358 p., 1955.

Revision of a 1947 book intended for classroom use. General aspects of erosion and methods of reducing erosion are covered.

Bennett, R. R. See Rasmussen, W. C., 1.

Benson, Ezra Taft.

An effective watershed program: Soil Conserv., v. 20, no. 7, p. 158-162, 1955.

Watershed protection acts and the benefits derived therefrom are discussed.

Benson, M. H. See Preston, H. A.

Benson, Manuel A. See Paulhus, J. L. H.; Potter, W. D., 1, 2; Rowe, R. R.; Todd, D. K., 7; Whisler, B. A. 


\section{Benson, Norman G.}

Observations on anchor ice in a Michigan trout stream: Ecology, v. 36, p. 529-530, 1955.

Formation and release of anchor ice were observed, and the conditions were recorded.

Benton, George S.

(and Dominitz, Jack). Measuring evapotranspiration from atmospheric data: Am. Soc. Civil Engineers Proc., v. 82, no. HY 4, Paper 1035, 26 p., 1956.

The mass balance of water vapor in the atmosphere is used to evaluate evapotranspiration. Results are compared with those obtained by other methods.

Berg, Paul H. See Critchlow, H. T,

Bergen, Stephen W. See also Haber, D.

(and Capen, Charles H., Rawlins, G. S., Bechert, C. H., Thorpe, T. W., Cunningham, M. B., and Alexander, L. J.). State water resources legislation in 1955: Am. Water Works Assoc. Jour., v. 47, no. 9, p. 845-857, 1955.

A description by States is given.

Berger, Bernard B.

Use of hexadecanol in reservoir evaporation reduction: Am. Water Works Assoc. Jour., v. 50, no. 7, p. 855-858, 1958.

Human toxicity potential, effect on fish, effect on water-treatment processes, and resistance to biological attack of hexadecanol were studied in the laboratory.

Bergstrom, Robert E. See also Hackett, J. E.

1. Groundwater possibilities in northeastern Illinois-a preliminary geologic report: Ill. Geol. Survey Circ. 198, 23 p., 1955.

2. (and Walker, Theodore R.). Groundwater geology of the East St. Louis area, Illinois: Ill. Geol. Survey Rept. Inv. 191, 44 p., 1956.

3. (and Zeizel, Arthur J.). Groundwater geology in western Illinois-a preliminary geologic report: Ill. Geol. Survey Circ. 232, 28 p., 1957.

Bermes, Boris J.

1. Interim report on the ground-water resources of Flagler County, Florida: Fla. Geol. Survey Inf. Circ., no. 13, 32 p., 1958.

Deposits of sand, marl, shell, and clay yield small quantities of nonartesian water. The underlying limestone yields large quantities of artesian water of highly variable mineralization.

2. Interim report on the geology and ground-water resources of Indian River County, Florida: Fla. Geol. Survey Inf. Circ., no. 18, 74 p., 1958.

The yield and quality of water from each of three aquifers are described.

Berndt, Gerald D. See Decker, F. W.

BERNDT, H. W.

(and Gibbons, R. D.). Root distribution of some native trees and understory plants growing on three sites within ponderosa pine watersheds in Colorado: Rocky Mtn. Forest Expt. Sta. Paper 37, 14 p., 1958.

The root distribution of 8 plant species on 3 different soils of the Colorado Front Range is reported.

Bernstein, Leon.

The needs and uses of water by plants, in U.S. Department of Agriculture, Water: Yearbook of Agriculture 1955, p. 18-25.

Plantphysiology and the reaction of plants to various amounts of water are described. 
Berrill, N. J.

Will the ice age return?: Eng. Jour., v. 38, no. 1, p. 30-32, 1955.

The progressive warming of the Arctic and its consequences are discussed.

Berry, Albert E.

1. Water pollution: Eng. Jour., v. 38, no. 9, p. 1181-1183, 1955.

Growth of population and industry and a net reduction in water resources are seen to be major factors in water-pollution problems in Canada.

2. Ontario water resources act: Am. Water Works Assoc. Jour., v. 50, no. 9, p. 1127-1131, 1958.

Legislation of 1956 relating to water resources is described. (Discussion by C. G. Russell Armstrong.)

Berry, Frederick A. See also Decker, F. W.

Evaluation of weather modification experiments: Am. Water Works Assoc. Jour., v. 48 , no. 8, p. 973-981, 1956.

Methods of analysis are described. It is concluded that cloud seeding works. (Discussion by Fred W. Decker, v. 48, no. 9, p. 1193-1196, 1956.)

Berry, William $\mathrm{H}$.

(and Hassig, Elmer). Control of Keams Canyon Wash: Jour. Soil and Water Conserv., v. 11, no. 3, p. 117-120, 1956.

The history of valley erosion in a reach in northern Arizona and the measures taken to control that erosion are discussed.

Berry, William L. See Morris, S. B., 1.

Bertle, F. A. See Garstka, W. U., 2.

Bertoni, Jose.

(and Larson, W. E., and Schrader, W. D.). Soil and water management and conservation: Soil Sci. Soc. America Proc., v. 22, p. 571-574, 1958.

Infiltration rates were determined from rainfall intensity and runoff rates on small plots by the graphical method of Sharp and Holtan.

Bessey, Roy F. See Foote, L. H.

Bethlahmy, Nedavia.

1. (and Barr, George). Bull Run Watershed; Portland's water source: Am. Forests, v. 63, no. 6, p. 16-18, 62-64, 1957.

Events leading to the creation of the Bull Run Reserve in 1892 are reviewed. The role of watershed research and its importance to the future development of the reserve are discussed.

2. (and Anderson, H. Kenneth). Watershed research in Portland, Oregon: Am. Water Works Assoc. Jour., v. 50, no. 1, p. 110-114, 1958.

The problems of fire control, revegetation of denuded areas, erosion and siltation, and ways of increasing streamflow are being studied.

3. Forests and water yield: Am. Soc. Civil Engineers Proc., v. 84, no. SA 6, Paper 1848,5 p., 1958.

Problems involved in the yield of water from forested areas are reviewed. (Discussion by J. C. Stevens, v. 85, no. SA 1, Paper 1921, p. 37-38, 1959; and author's closure, v. 85, no. SA 4, Paper 2098, p. 107, 1959.)

Bevans, J. T. See Dunkle, R. V.

Bieber, P. P. See Nace, R. L., 3. 
Bierschenk, William H. See also Raymond, J. R.

1. Ground-water resources of the Kingston quadrangle, Rhode Island: R.I. Devel. Council Geol. Bull., no. 9, 60 p., 1956.

The area, the aquifers, and the amount and management of ground water are described. Quantitative interpretations and suggestions for needed work to improve quantitative estimates of potentialities for development are given.

2. Hydrological aspects of radioactive waste disposal: Am. Soc. Civil Engineers

Proc., v. 84, no. SA 6, Paper 1835, 11 p., 1958.

Behavior of low-level radioactive wastes can be predicted from geologic and hydrologic data.

Bigler, S. G

(and Tarble, R. D.). Applications of radar weather observations to hydrologyfinal report on contract CWB 9090: Texas A. and M. Research Found., Nov. 1957.

BigwOOD, BuRke L.

1. (and Thomas, M. P.). A flood-flow formula for Connecticut: U.S. Geol. Survey Circ. 365, 16 p., 1955.

A formula is derived.

2. (and Thomas, Mendall P.), Connecticut Flood Planning Session, I-Basic magnitude and frequency relationship: Conn. Soc. Civil Engineers, $73 \mathrm{~d}$ ann. rept., p. 76-92, 1957.

This paper describes a regional flood-frequency relationship, the use of historical data, and the effect of the floods of 1955 on the relationship.

Billingsley, G. A. See also Fish, R. E.

(and Fish, R. E, and Schipf, R. G.). Water resources of the Neuse River basin, North Carolina: U.S. Geol. Survey Water-Supply Paper 1414, 89 p., 1957.

The occurrence, quality, and present use of surface and ground water are described.

Bishop, Earnest W.

Geology and ground-water resources of Highlands County, Florida: Fla. Geol. Survey Rept. Inv. 15, 115 p., 1956.

Geography, geology, nonartesian and artesian ground water recharge and discharge, water utilization, and water quality are described.

Biswell, H. H.

(and Schultz, A. M.). Surface runoff and erosion as related to prescribed burning: Jour. Forestry, v. 55, p. 372-374, May 1957.

Observations indicated that no surface runoff or erosion following prescribed burning could be related to the burning itself.

BJorkвoм, JoHN C.

(and Trimble, George $R, J r$. .). Sow seed in logging roads to control erosion: Northeastern Logger, v. 7, p. 18-19, 36-37, 46, 1958.

The report describes the results from tests of several combinations of seed, lime, and fertilizer.

BJorkLUnd, L. J. See also Babcock, H. M.

1. Reconnaissance of ground-water conditions in the Crow Flats area, Otero County, New Mexico: N. Mex. State Engineer Tech. Rept., no. 8, 25 p., 1957.

This report describes the occurrence, availability, quality, movement, and use of ground water in the Crow Flats area.

2. (and Brown, R. F.). Geology and ground-water resources of the lower South 
Platte River valley between Hardin, Colorado, and Paxton, Nebraska, with a section on chemical quality of the ground water, by H. A. Swenson: U.S. Geol. Survey Water-Supply Paper 1378, 431 p., 1957.

The area described covers about 3,200 square miles, a part of which is irrigated.

3. Geology and ground-water resources of the lower Lodgepole Creek drainage basin, Nebraska, with a section on chemical quality of the water, by E. R. Jochens: U.S. Geol. Survey Water-Supply Paper 1410, 76 p., 1957.

The area described covers a distance of about 95 miles along the stream valley in Nebraska from the Wyoming State line to the Colorado State line.

Black, A. P.

Salt water encroachment-a water resource problem: Water Works Eng., v. 109, no. 4, p. 338-342, 1956.

Relations of salt and fresh water for various coastal conditions are described, and methods of preventing salt-water encroachment are discussed.

BLACK, R. D.

Growing use of water for irrigation in Illinois: Am. Water Works Assoc. Jour., v. 49 , no. 5 . p. 537-540, 1957.

Methods of recording growth, inadequacy of current methods, and pattern of development are discussed.

BLACK, Robert F.

Permafrost, water supply, and engineering geology of Point Spencer Spit, Seward Peninsula, Alaska: Arctic, v. 11, no. 2, p. 103-116, 1958.

The report of a reconnaissance is given.

Blair, M. B.

Water rights in Texas: Soil and Water, v. 4, no. 2, p. 18-19, 1955.

A brief statement on water rights is given.

Blaisdell, Fred W. See also Kindsvater, C. E., 1; Li, W. H., 2; Stevens, J. C.

(and Donnelly, Charles A.). Hood inlet for closed conduit spillways: Agr. Eng. v. 37 , no. 10, p. 670-672, 1956.

The hood inlet will cause the conduit to flow completely full giving superior hydraulic performance. The filling of the conduit is completely reliable and predictable.

Blake, G. R. See Brill, G. D.

Blake, Nelson Manfred.

Water for the cities: Syracuse, N.Y., Syracuse Univ. Press, 341 p., 1956.

A history of the water supply problems of cities is discussed with emphasis on New York, Philadelphia, Baltimore, and Boston during the years 1790-1860.

Blakely, B. D.

(and Coyle, J. J. and Steele, J. G.). Erosion on cultivated land, in U.S. Department of Agriculture, Soil: Yearbook of Agriculture 1957, p. 290-307.

The major parts of modern soil management are to protect soil from erosion and for soil to hold as much of the rain as possible in place where crops can use it.

Blanchard, Francis B. See also Wilson, M. T.

Operational economy through applied hydrology: Western Snow Conf. Proc., p. 35-48, Apr. 1955.

Maximum income and economy can be attained only by evaluating alternative operating schedules in the light of the probability of further hydrologic events which may affect the results. Three operating problems and a general procedure are described. 
Blaney, Harry F. See also Criddle, W. D., 3; Penman, H. L.

1. (and Corey, Gilbert L.). Evaporation from water surfaces in California: Calif. Div. Water Resources Bull., no. 54-B, 98 p., 1955.

The report describes evaporation investigations and types of pans, and it includes evaporation data.

2. Evaporation from and stabilization of Salton Sea water surface: Am. Geophys. Union Trans., v. 36, p. 633-640, 1955.

The formation of Salton Sea and its changes in water level are described. A stabilization of the water surface below an elevation of minus 220 feet prior to the year 1980 is indicated. (Discussions by Carl Rohwer and N. J. Cochrane, and author's closure, v. 37, p. 786-788, 1956.)

3. (and Muckel, Dean C.). Evaporation and evapotranspiration investigations in San Francisco Bay area: Am. Geophys. Union Trans., v. 36, p. 813-820, 1955 .

Studies were made to determine probable evaporation and evapotranspiration losses that would occur if barriers were constructed across San Francisco Bay to exclude salt water. Estimates were made of annual and monthly losses for the 1921-52 period and for 5 critical years.

4. Evaporation study at Silver Lake in the Mojave Desert, California: Am. Geophys. Union Trans., v. 38, p. 209-215, 1957.

Silver Lake was formed in 3 days and was entirely dry 2 years later. Daily weather, water level, and water temperature observations were made for 1 year. These data were used to determine a coefficient for converting pan evaporation to lake evaporation. (Discussion by N. J. Cochrane, and author's closure, v. 39, p. 1163, 1958.)

5. Evaporation from free water surfaces at high altitudes: Am. Soc. Civil Engineers Trans., v. 123, p. 385-395, 1958.

Data are presented concerning evaporation of water in several Western States. A method of estimating monthly evaporation for the entire year from temperature measurements and other data are given. (Discussion by Carl Rohwer, Kenneth M. Turner, and Irvin M. Ingerson, and John W. Shannon.)

Buench, Thomas. See also Brooks, N. H.; Carey, W. C.; Chien, N., 1, 2, 3; Delleur, J. W.; Einstein, H. A., 2.

Scale relations among sand-bed rivers including models: Am. Soc. Civil Engineers

Proc., v. 81, Separate 667, 16 p., 1955.

The value and the practicability of model simulation are discussed. The origin of regime-theory formulas and their applications to rivers is explained, and their use in designing model scales shown by example. (Discussion by Hans Einstein, v. 81, Paper 794, p. 13-15, 1955, and author's closure, v. 82, no. HY 1, Paper 881, p. 19 23, 1956.)

Buiss, Eldred S. See Schiff, L., 2.

BLOODGOOD, D. E.

(and Boegly, W. J., and Smith, C. E.). Sedimentation studies: Am. Soc. Civil Engineers Proc., v. 82, no. SA 5, Paper 1083, 21 p., 1956. Laboratory studies showed that removal of sediment depends on the force of the incoming water. (Discussion by N. Claes H. Fischerstrom, v. 83, no. SA 2, Paper 1227, p. 5-8, 1957, and authors' closure, v. 83, no. SA 5, Paper 1422, p. 9, 1957.)

Broodgood, Don E. See Howe, R. H. L., 1.

Bloodworth, M. E.

1. (and Page, J. B., and Cowley, W. R.). A thermoelectric method for determining 
the rate of water movement in plants: Soil Sci. Soc. America Proc., v. 19, no. 4, p. 411-414, 1955.

The method allows repeated measurements on the same plant without damage to it and, therefore, the effects of temperature, humidity, and wind velocity can be defined.

2. (and Page, J. B., and Cowley, W. R.). Some applications of the thermoelectric method for measuring water flow rates in plants: Agronomy Jour., v. 48, no. 5 , p. 222-228, 1956.

Maximum transpiration rates for cotton plants were found to occur when relative humidities varied between 42 and 50 percent, temperatures between $95^{\circ}$ to $100^{\circ} \mathrm{F}$, and wind velocities between 1 and 4 miles per hour. Soil moisture tension appeared to control absorption and movement of water in plants.

3. (and Page, J. B.). Use of thermistors for the measurement of soil moisture and temperature: Soil Sci. Soc. America Proc., v. 21, no. 1, p. 11-15, 1957.

The thermistor used as a combination heating element and temperature indicator is an accurate moisture indicating device.

Bock, Robert O. See Zee, C. H.

Boegly, W. J. See Bloodgood, D. E.

Bogardi, John L. See Laursen, E. M., 1; Liu, H. K., 1.

Boldizsar, $\mathrm{T}$.

The distribution of temperature in flowing wells: Am. Jour. Sci., v. 256, no. 4, p. 294-298, 1958.

The temperatures in a well in which fluid enters at a single level are calculated and compared with observations for a well near Colorado Springs, Colo.

Bolt, G. H.

(and Miller, R. D.). Calculation of total potentials of water in soil: Am. Geophys.

Union Trans., v. 39, p. 917-928, 1958.

The total potential is treated as the sum of gravitational, pressure, osmotic, and adsorption components.

Bondurant, D. C. See Laursen, E. M., 1.

Bondurant, James A.

Developing a furrow infiltrometer: Agr. Eng., v. 38, no. 8, p. 602-604, 1957.

An infiltrometer which simulates closely the infiltration conditions existing in a furrow during irrigation is described.

Bookman, Max. See Isherwood, J. D.

Bordne, ERICH.

Some hydrologic aspects of the flood of August 1955 in a Connecticut valley: Geog. Rev., v. 47, p. 211-223, Apr. 1957.

A geographic study of the Naugatuck flood is presented.

Boreli, Muaden.

Free-surface flow toward partially penetrating wells: Am. Geophys. Union Trans., v. 36, p. 664-672, 1955 .

The form of the free surface and the characteristics of flow have been determined by the relaxation technique. An improved formula for rate of discharge is presented. (Discussion by Joel B. Cox, and author's closure, v. 37, p. 637-641, 1956.)

Borg, Sidney F.

Some contributions to the wedge-water entry problem: Am. Soc. Civil Engineers 
Proc., v. 83, no. EM 2, Paper 1214, 28 p., 1957.

Results of a study of the wedge-water entry problem based on a new formulation are presented.

Borland, Whitney M. See also Benedict, P. C., 1; Mostafa, M. G.; Terrell, P. W.

1. (and Miller, Carl R.). Distribution of sediment in large reservoirs: Am. Soc. Civil Engineers Proc., v. 84, no. HY 2, Paper 1587, 18 p., 1958.

Factors affecting the distribution and two methods of predicting the probable distribution are given.

2. Investigation of snow conditions causing avalanches: U.S. Army Reserve 5002d Research and Devel. Unit, Interim Rept., nos. 1 to 7, 1952-58.

The report summarizes field measurements of snow conditions at several Colorado mountain passes.

Bose, N. K. See Lane, E. W., 2.

BotTomLey, G. A.

The free oscillations of Lake Wakatipu, New Zealand: Am. Geophys. Union Trans., v. 37, p. 51-55, 1956.

The periods of vibration and the surface shapes for several longitudinal oscillations for the lake are deduced from the behavior of a laboratory model.

Boulos, N. See Fathy, A.

Bourget, S. J.

(and Elrick, D. E., and Tanner, C. B.). Electrical resistance units for moisture measurements; their moisture hysteresis, uniformity, and sensitivity: Soil Sci., v. 86 , no. 6, p. 298-304, 1958.

Several types of units were evaluated, and the effect of a resin treatment on the calibration and deterioration of gypsum units were determined. A type of unit is recommended for each of several conditions.

Bouwer, Herman.

(and Zwerman, Paul J., Gray, Harold E., and Levine, Gilbert). Drainage research methods on stony soils: Agr. Eng., v. 36, no. 9, p. 591-592, 1955.

Techniques are presented for measuring water-table elevations and ground-water pressures in stony soils.

Bouyoucos, George J.

Improved soil moisture meter: Agr. Eng., v. 37, no. 4, p. 261-262, 1956.

The new meter, which uses alternating current, is described.

Bowers, Nathan A.

Rainfall histories from tree rings?: Eng. News-Rec., v. 158, no. 10, p. 53-56, Mar. 7, 1957.

The methods and limitations are discussed.

Bowman, J. R. See Harris, D. L., 4.

Boyce, Earnest.

Water and other natural resources: Water and Sewage Works, v. 105, no. 5, p. 193-195, 1958.

A few of the many special problems that must be considered in the effective utilization of our water resources are itemized. 


\section{Boyd, Donald W.}

Rainfall intensities at seven Canadian cities: Natl. Research Council, Canada, Bldg. Note, no. 15, 3 p., 1955.

Boyer, M. C.

1. A correlation of the characteristics of great storms: Am. Geophys. Union Trans., v. 38 , p. 233-238, 1957.

A method is presented whereby storms may be compared by means of a mathematical correlation of the characteristics. Use in design of flood-control works is suggested. (Discussions by Ven Te Chow and D. A. Kraijenhoff van de Leur, and author's closure, v. 39, p. 124-127, 1958.)

2. Water supply versus irrigation in humid areas: Am. Soc. Civil Engineers Proc., v. 84, no. IR 1, Paper 1500, 13 p., 1958.

Watershed inventories are needed to assure optimum use of the water supply and to determine present and future supplemental needs. An example of an inventory is given.

Bradley, Edward.

1. Geology and ground-water resources of the upper Niobrara River basin, Nebraska and Wyoming, with a section on chemical quality of the ground water, by F. H. Rainwater: U.S. Geol. Survey Water-Supply Paper 1368, 70 p., 1956.

The area described comprises about 6,600 square miles in northwestern Nebraska and east-central Wyoming. The west half consists chiefly of rolling plains; the east half is in the Sand Hills region of Nebraska.

2. (and Johnson, Carlton R.). Ground-water resources of the Ladder Creek area in Kansas, with a section on the chemical quality of water, by Robert A. Krieger: Kans. Geol. Survey Bull. 126, 194 p., 1957.

This report describes the geology and hydrology of the heavily pumped area in order to further the understanding of the quantity and quality of the available ground water and to plan for increased future use.

3. (and Johnson, Carlton R.). Geology and ground-water hydrology of the valley of the Republican and Frenchman Rivers, Nebraska: U.S. Geol. Survey Water-Supply Paper 1360-H, p. 589-713, 1957.

This is a report on a preliminary investigation to relate the occurrence of ground water to irrigation and flood control and to aid in the evaluation of the effects of irrigation on the land in the area.

Bradley, J. N. See Liu, H. K., 2.

Braham, Roscoe R., Jr.

(and Battan, Louis J.). Effects of seeding cumulus clouds: Am. Water Works Assoc. Jour., v. 50, no. 2, p. 185-192, 1958.

Cloud physics research, based on long and careful field experiments, shows that formation of precipitation can be induced in small cumulus clouds, in which it would not form naturally, through use of water spray. Dry-ice seeding apparently was not effective.

Brakensiek, D. L. See also Potter, W. D., 1.

1. (and Zingg, A. W.). Application of the extreme value statistical distribution to annual precipitation and crop yields: U.S. Dept. Agriculture, ARS 41-13, 14 p., 1957.

The extreme-value theory satisfactorily represents the distribution of annual crop yields and annual precipitation amounts. The procedure is simple. Selected crop or precipitation measures can be characterized by their probability of occurrence. 
2. Fitting a generalized log-normal distribution to hydrologic data: Am. Geophys. Union Trans., v. 39, p. 469-473, 1958.

A statistical distribution is developed which makes it possible to fit a wide range of positively skewed hydrologic data. Two fitting processes are developed and examples are given.

Bramer, Henry C. See Hoak, R. D., 2.

Branch, Harilee, Jr.

The functions of private enterprise in water resource development and conservation:

Edison Elec. Inst. Bull., v. 24, p. 69-72, Mar. 1956.

An address before the National Conference on Water Resources Policy, St. Louis, Mo., Jan. 25, 1956 is reported.

Branson, Cart C. See Reed, E. W.

Braudeau, G. See Lane, E. W., 2.

Breeding, S. D.

(and Montgomery, J. H.). Floods of September 1952 in the Colorado and Guadalupe River basins, central Texas: U.S. Geol. Survey Water-Supply Paper 1260-A, p. 1-47, 1954 [1955].

Rainfall as great as $\mathbf{2 6}$ inches produced record floods on many large and small streams. Stages and discharges are given.

BrehM, C. D.

Which way blows the wind?: Soil Conserv., v. 20, no. 11, p. 246-248, 1955.

Prevailing wind directions in the northern plains States are given.

Brennan, Robert. See Matthai, H. F., 3.

Breon, Theodore F. See Trimble, G. R., Jr., 3.

Bretschneider, Charles L.

Hurricane design wave practices: Am. Soc. Civil Engineers Proc., v. 83, no. WW 2, Paper 1238, 33 p., 1957.

Two important concepts are described which allow the design wave and its recurrence interval to be obtained.

Bretting, Aage Einer.

Stable channels: Eng. Prog. Univ. Fla., Tech. Paper 144, v. 12, no. 7, 116 p., 1958.

Brewer, Max C.

The thermal regime of an arctic lake: Am. Geophys. Union Trans., v. 39, p. 278284, 1958.

The regime of a shallow lake near Barrow, Alaska, is described.

Brier, Glenn W. See Panofsky, H. A.

BrILL, G. D.

(and Blake, G. R.). Residual effect of irrigation on soil physical properties and on runoff: Agronomy Jour., v. 50, no. 10, p. 619-621, 1958.

Seven years of irrigation resulted in increased bulk density, lowered aggregate stability, and increased runoff from rainfall.

Brittain, Robert.

Rivers, man and myths: Garden City, N.Y., Doubleday and Co., 288 p., 1958.

The book traces the development of civilization and its relation to rivers. 
Broadfoot, W. M. See also Andrews, L. A.; Doss, B. D.

(and Burke, H. D.). Soil-moisture constants and their variation: U.S. Forest Service, Southern Forest Expt. Sta. Occasional Paper 166, 27 p., 1958.

Values are given for the most commonly used constants, under specific soil and cover conditions.

Brookhart, J. W. See Schlanger, S. O.; Robinove, C. J.

Brooks, Norman H. See also Baumann, P.; Liu, H. K., 1; Vanoni, V. A.

Mechanics of streams with movable beds of fine sand: Am. Soc. Civil Engineers Trans., v. 123, p. 526-549, 1958.

A laboratory study was made to determine what factors govern the equilibrium rate of transportation of fine sand in suspension. The transportation rate could not be expressed as a unique function of the bed shear stress, channel geometry, and sand properties. A qualitative relation between slope and the independent variables, mean velocity and depth, was obtained. (Discussion by Thomas Blench, James R. Barton, Hans A. Einstein and Ning Chien, Enos J. Carlson and M. Gamal Mostafa, Hsin-Kuan Liu, and Pin-Nam Lin.)

Brown, Carl B.

1. (and Murphy, Warren T.). Conservation begins on the watersheds, in U.S. Department of Agriculture, Water: Yearbook of Agriculture 1955, p. 161-165.

This paper summarizes the legal actions related to conservation based on management of watersheds.

2. Developments in the small watershed approach to flood prevention and conservation: Jour. Soil and Water Conserv., v. 10, no. 1, p. 13-18, 1955.

Three pieces of national legislation that will speed up the small watershed approach to flood prevention and conservation are described. The accomplishments in 11 watersheds under the Flood Control Act of 1936 and in a pilot program on 60 small watersheds are given.

3. Factors affecting the useful life of reservoirs: Am. Soc. Civil Engineers Proc., v. 84, no. IR 1, Paper 1503, 8 p., 1958.

Length of life and service value of reservoirs are controlled by rate of silting.

Brown, Delbert W.

1. Ground-water resources of the Middle Loup division of the lower Platte River basin, Nebraska, with a section on chemical quality of the ground water, by Frank H. Rainwater: U.S. Geol. Survey Water-Supply Paper 1258, 83 p., 1955.

The characteristics of the aquifers, the yields of wells, and the factors controlling the fluctuations of the water table are described. Water is hard but otherwise satisfactory.

2. (and Kenner, W. E., and Brown, Eugene). Interim report on the water resources of Brevard County, Florida, with special reference to the central area: Fla. Geol. Survey Inf. Circ., no. 11, 111 p., 1957.

A summary of available information and a review of the progress of a cooperative investigation are presented.

3. Changes in the chloride content of ground water in Pinellas County, Florida, between 1947 and 1956: Fla. Geol. Survey Inf. Circ., no. 16, 11 p., 1958.

Brown, Eugene. See Brown, D. W., 2; Kenner, W. E.; Robinson, W. H.; Thomson, M. T., 2.

Brown, H. E.

(and Dunford, E. G.). Streamflow in relation to extent of snow cover: Rocky 
Mtn. Forest Expt. Sta. Paper 24, 9 p., 1956.

Reports results of a study made on the Fraser Experimental Forest in 1950.

Brown, Howard B.

The meaning, significance, and expression of commonly measured water quality criteria and potential pollutants: La. Eng. Expt. Sta. Bull., no. 58, 46 p., 1957.

Material presented is intended to be of primary value to administrative people and to technical people with a limited scope of interest in stream sanitation.

Brown, P. N. See Roberts, C. M.

Brown, Philip Monroe

Well logs from the Coastal Plain of North Carolina: N.C. Div. Mineral Resources Bull. 72, 68 p., 1958.

This report contains the logs of 82 wells. The information may be used to determine the lithology and geographic extent of water-bearing formations.

Brown, R. F. See Bjorklund, L. J., 2.

Brown, R. J. E.

Observations on break-up in the Mackenzie River and its delta in 1954: Jour. Glaciology, v. 3, no. 22, p. 133-141, 1957.

Winter conditions on Mackenzie River and delta in Northwest Canadaarediscussed. Daily observations during breakup period of the river for 1954 are recorded, as well as a general record of breakup in the delta and detailed observations of breakup in one of the main channels.

Brown, Robert M. See Singer, I. A.

Bruce, J. P.

Preliminary estimates of probable maximum precipitation over southern Ontario: Eng. Jour., v. 40, no. 7, p. 978-984, 1957.

The method is described, Hurricane Hazel is analyzed, and storm transposition is discussed.

BruIN, JACK.

1. (and Hudson, H. E., Jr.). Selected methods for pumping test analysis: Ill. Water Survey Rept. Inv. 25, 54 p., 1955.

This paper reviews four common aquifer tests, giving assumptions, advantages, disadvantages, and applicability to particular types of problems.

2. Specific capacity as applied to water wells: Water Works Eng., v. 109, no. 3, p. 212-213, 1956.

Specific capacity is defined, and its variation with pumping rate and pumping period is explained.

Brune, Gunnar M.

Sediment is your problem; wasted soil and water: U.S. Dept. Agriculture, AIB 174, 15 p., 1958.

This article answers the following questions: (1) How does sediment affect you? (2) Where does sediment come from? (3) What can we do? (4) What alternatives are there? and (5) How effective is soil conservation?

Bryant, G. T.

(and Geyer, J. C.). The travel time of radioactive wastes in natural waters: Am. Geophys. Union Trans., v. 39, p. 440-445, 1958.

Past studies of mixing and movement are drawn on to depict the time and space distribution of radioactive contaminates in natural waters. 
Bryson, ReID A.

1. (and Ragotzkie, Robert A.). Rate of water replacement in a bay of Lake Mendota, Wisconsin: Am. Jour. Sci., v. 253, no. 9, p. 533-539, 1955.

Measurements of rates of wind-driven water replacement (both by vertical motion and horizontal eddying) for a bay are reported. A few hours to several hundred hours are required for replacement by vertical motion, depending on the wind.

2. (and Bunge, William W., Jr.). Ice on Wisconsin lakes: Wis. Univ. Dept. Meteorology Rept., pt. 2, 17 p., 1956.

Bue, Conrad D. See Love, L. D., 2.

Buell, C. Eugene.

An evaluation of the results of cloud seeding in western New Mexico and southeastern Arizona during July and August, 1951 and 1952: Am. Meteorol. Soc. Bull., v. 36, no. 1, p. 6-15, 1955.

The method used consists of estimating the amount of natural rainfall that might be expected from the mixing ratios at the 700 and the 500 millibar levels and the temperature difference between these levels, and comparing this estimate with the actual rainfall from the seeded part. The effectiveness of cloud seeding could not be established by this method with the available data.

BuetTNer, $\mathrm{K}$.

1. A small portable meter for soil heat conductivity and its use in the O'Neill test: Am. Geophys. Union Trans., v. 36, p. 827-830, 1955.

The construction and use of the meter are described.

2. Evaluation of soil heat conductivity with cylindrical test bodies: Am. Geophys. Union Trans., v. 36, p. 831-837, 1955.

Different solutions of the temperature increase with time of a heated cylinder are discussed.

Buhle, M. B.

Uses and limitations of electrical prospecting for water supplies: Ill. Geol. Survey Repr. Ser. 1958-0, 5 p., 1958.

The theory, methods, and limitations of resistivity work by the State Survey in Illinois are discussed.

Bundrant, C. O. See Dehlinger, P.

Bunge, Willitam W., Jr. See Bryson, R. A., 2.

Bunnag, Din. See LaMoreaux, P. E., 2.

Burford, Hugh. See Priddy, R. R., 1.

Burford, J. B.

(and Lillard, J. H.). Runoff-how fast and how much: Soil Conserv., v. 24, no. 4, p. 81-83, 1958.

Variability of runoff and the need for and methods of gaging runoff from small watersheds are covered.

Burgy, Robert H. See also Scott, V. H., 2.

1. (and Luthin, J. N.). A test of the single and double-ring types of infiltrometers: Am. Geophys. Union Trans., v. 37, p. 189-191, 1956.

Field experiments showed no significant difference in the results obtained with the two types. The number of ring measurements required to characterize the infiltration rate of an area was determined. (Discussion by Walter T. Wilson, Leonard Schiff, and author's closure, v. 38, p. 260-261, 1957.) 
2. Watershed management and water yield: Western Snow Conf. Proc., p. 4-9, Apr. 1957.

Watershed records are being obtained to define the effect of vegetation management on streamflow.

3. (and Pomeroy, C. R.). Interception losses in grassy vegetation: Am. Geophys. Union Trans., v. 39, p. 1095-1100, 1958.

Results of a series of laboratory tests of the interception process are reported.

4. Water yields as influenced by watershed management: Am. Soc. Civil Engineers Proc., v. 84, no. IR 2, Paper 1590, 10 p., 1958.

Studies show that replacement of brush by grass appreciably increases runoff. Characteristics of vegetation which affect runoff are examined.

Burke, H. D. See Broadfoot, W. M.

BuRns, Joseph I.

(and Strauss, Fred A.). Graphical forecast errors: Western Snow Conf. Proc., p. 86-93, Apr. 1957.

A multiple graphical relation for forecasting runoff from snowmelt is analyzed.

Burrild, Meredith F. See Graham, J. B., 2.

Burrows, W. C.

(and Kirkham, Don). Measurement of field capacity with a neutron meter: Soil Sci. Soc. America Proc., v. 22, no. 2, p. 103-105, 1958.

An experiment to determine the moisture vs. time curve, and hence the field capacity, was carried out at 6 -inch increments to a depth of 5 feet on 4 soils.

Burt, E. M. See Deutsch, M., 2.

Burt, Wayne B.

(and Marriage, Lowell D.). Computation of pollution in the Yaquina River estuary: Sewage and Indus. Wastes, v. 29, no. 12, p. 1385-1389, 1957.

A procedure that may have use as a guide for future studies is described.

Busby, C. E. See also Critchlow, H. T.

1. Regulation and economic expansion, in U.S. Department of Agriculture, Water: Yearbook of Agrieulture 1955, p. 666-676.

Common and statutory water rules are described, and the need for modernizing water legislation is stressed.

2. Water use and water rights: Soil Conserv., v. 21, no. 7, p. 156-160, 1956.

A general discussion is presented.

Bushman, F. X.

Ground-water data for Dwyer Quadrangle, Grant and Luna Counties, New Mexico: N. Mex. Inst. Mining and Mineral Resources Circ. 37, 18 p., 1955.

This report contains a brief discussion of the ground-water resources, tabular data on wells and springs, and a map showing locations of the wells and springs.

Buswell, Arthur M.

1. (and Rodebush, W. H.). Water: Fla. Univ. Eng. and Indus. Expt. Sta. Leaflet 77, 11 p., 1956.

2. (and Rodebush, Worth H.). Water: Sci. Am. v. 194, no. 4, p. 77-89, 1956.

Water structure, properties, and hydrates are described.

Butler, Robert G. See Orlob, G. T., 2.

Butler, Stanley S.

Engineering hydrology: Englewood Cliffs, N.J., Prentice-Hall, 356 p., 1957. 
A concise quantitative approach to runoff, particularly flood flow and ground-water yield is given. The interrelation of surface-water and ground-water runoff is discussed and precipitation, evaporation, transpiration, climate, and basic characteristics, all essential factors in runoff analysis, are treated. Collection of basic data is described and these data are analyzed. Many problems are included.

Byrnes, William R. See Reigner, I. C., 2.

Cagle, Joseph W., JR.

(and Floyd, Billy L.). Interim report on ground water in Escambia County, Alabama, with special reference to the Brewton area: Ala. Geol. Survey Inf. Ser. 7, 30 p., 1957.

CAHILl, J. M. See Johnson, P. W.

Cahoon, G. A. See Stolzy, L. H.

Calef, Weslex C. See also White, G. F., 2.

Winter weather type frequencies, northern Great Plains: U.S. OQG Environmental

Protection Tech. Rept., no. EP-64, 260 p., 1957.

California Department of Water Resources.

1. Interim report on lower San Joaquin valley water quality investigation: Calif. Dept. Water Resources, 81 p., 1956.

2. Quality of surface waters in California, 1951-1954; a report to the California Legislature and regional Water Pollution Control Boards: Calif. Div. Water Resources Plan., Water Quality Inv. Rept., no. 15, 519 p., 1956.

Field and laboratory procedures are described, and data on the quality of surface waters are included.

3. Kaweah River flows, diversions, and service areas, 1949-1955: Calif. Div. Water Resources Bull. 49-B, 158 p., 1956.

4. Quality of surface and ground waters in upper Santa Ana valley: Calif. Dept. Water Resources Bull. 40-57, 140 p., 1957.

A compilation of mineral analyses of surface and ground-waters, a description of the methods of analysis employed, and a discussion of water-quality standards are included in this report. More than 900 surface-water and 2,400 ground-water analyses are presented.

5. Lake County investigation: Calif. Dept. Water Resources Bull., no. 14, 191 p., 1957.

The report describes the area, the water supply, water utilization and supplemental requirements, and plans for water development and summarizes the conclusions and recommendations.

7. Salinity control barrier investigation: Calif. Div. Resources Plan. Bull., no. 60, 79 p., 1957.

An analysis of two plans for salinity control of Delta channels is presented.

8. Report on 1956 Cooperative Study Program, water use and water rights along

Sacramento River and in Sacramento-San Joaquin delta: Calif. Dept. Water Resources v. 1, 99 p., 1957.

This is a cooperative report by U.S. Bureau of Reclamation, California Department of Water Resources, and Sacramento River and Delta Water Association. The purpose of the report is to present a summary of information needed for reaching agreement on water rights. Volume 1 contains brief descriptions of the methods and summaries of the findings. Volume 2 contains 606 tables.

9. San Luis Obispo County investigation, Vol. 1: Calif. Dept. Water Resources Bull. 18, 288 p., 1958. 
10. Recommended water well construction and sealing standards, Mendocino County: Calif. Div. Water Resources Bull. 62, 169 p., 1958.

The report contains a major section on ground-water geology and hydrology of the county.

11. Sea-water intrusion in California: Calif. Div. Resources Plan. Bull. no. 63, 91 p., 1958.

Laboratory and field investigations of the feasibility of creating a pressure ridge in confined aquifers by means of injection wells and the effectiveness of such a ridge in preventing salt-water intrusion are described.

12. Reclamation of water from sewage and industrial wastes: Calif. Div. Resources Plan. Bull. no. 68, 24 p., 1958.

The report presents basic data on quantity and quality of waste discharges and pertinent information regarding development of sewage-treatment facilities and status of reclamation projects.

13. Water facts for Californians: Calif. Dept. Water Resources Pub., 15 p., 1958.

This is a general popular account.

California Disaster Office.

The big flood, California 1955: Calif. Printing Div. Doc. Sec., 126 p., 1956.

California Division of Water Resources.

1. Survey of mountainous areas: Calif. Div. Water Resources Bull. 56, 150 p., 1955.

Almost one-fourth of the surface water resources of California originates within the central Sierra Nevada region-the area under investigation in this bulletin. Maximum future water requirements and plans for projects that will satisfy these requirements are defined.

2. Report to the Water Project Authority of the State of California on seepage conditions in Sacramento Valley: Calif. Div. Water Resources, 129 p., 1955.

3. Report to the California State Legislature on Putah Creek cone investigation: Calif. Div. Water Resources, 211 p., 1955.

Rapid increases in use of ground water in the subject area and construction of a dam on Putah Creek caused local concern as to adequacy of the supplies. This report defines the magnitude of supplemental requirements.

4. Northeastern counties investigation; report on upper Feather River service area: Calif. Div. Water Resources, 293 p., 1955.

This report presents results of a determination of the ultimate water needs in the Feather River drainage basin. An inventory of available water resources includes estimates of stream runoff at specific locations, evaluations of the potential firm yields of possible water-storage developments, and preliminary results of studies of development plans that may enhance the economy of the drainage basin.

5. Memorandum report on water conditions in Antelope Valley, in Kern, Los Angeles, and San Bernardino Counties: Calif. Div. Water Resources, 27 p., 1955.

Water conditions in Antelope Valley are described from data on file.

6. Report to the California Water Project Authority of the State of California on feasibility of construction by the State of barriers in the San Francisco Bay system: Calif. Water Proj. Authority Rept., v. 9, 1955.

Contents of the volumes are: economic development of the San Francisco Bay area, navigation and transportation, water resources and water conservation, flood control and reclamation, water quality and waste disposal, sedimentation, geology, barrier plans design and construction, and financial analyses. 
7. Quality of ground water in the Stockton area, San Joaquin County: Calif. Div. Water Resources Water Quality Inv. Rept., no. 7, 57 p., 1955.

This is a review and analysis of geologic, hydrologic, and water quality data.

8. Ventura County investigation, Revised, Apr. 1956: Calif. Water Resources Board Bull. 12 , v. 2, 1956.

This comprehensive report includes a description of the area, the water supply (quantity and quality), water utilization and requirements, plans for water-supply development, and recommendations.

9. Santa Margarita River investigation: Calif. Div. Water Resources Bull. 57, v. 2, 1956.

Potential water requirements far exceed the supply. This report describes the area, the water supply, water utilization and requirements, legal considerations, and plans for water development.

10. Geology, hydrology, and water quality of alluviated areas in Mendocino County and recommended standards of water well construction and sealing: Calif. Div. Water Resources Water Quality Inv. Rept., no. 10, 211 p., 1956.

The report includes determination and identification of valley fill areas, a well canvas, water quality conditions, pollution sources, and prevalent and recommended methods of well construction and sealing.

11. Ground water quality monitoring program in California; progress report, 1953-51, to the California Legislature and regional Water Pollution Control Boards: Calif. Div. Water Resources Water Quality Inv. Rept., no. 14, 198 p., 1956.

The program to provide current information on mineral quality of ground waters, to detect significant changes in water quality, and to ascertain the area affected by the changes is described. Many data are given.

12. Report on weather modification operations in California, July 1952-June 1956: Calif. Dept. Water Resources, 12 p., 1957.

The report describes the licensing and reporting requirements that must be followed by those who attempt weather modification in California and lists the operations during the subject period.

California University Committee on Resejarch in Water Resources.

Suggestions for research in water resources: Calif. Univ. Water Resources Center Contr., no. 18, 48 p., 1958.

An inventory of suggestions are given under the headings (1) supply of water, (2) control and development of water, and (3) use of water.

California Water Pollution Control Board.

1. A survey of direct utilization of waste waters: Calif. Water Pollution Control Board Pub., no. 12, 80 p., 1955.

A review of foreign and domestic operations intended to demonstrate where utilization of waste waters is taking place, how it is accomplished, and what have been some of the problems associated with its use.

2. Report on continued study of waste water reclamation and utilization: Calif.

Water Pollution Control Board Pub., no. 15, 90 p., 1956.

The report describes reclamation of liquid digested sludge and reclamation of a raw sewage lagoon effluent.

3. Third report on study of waste water reclamation and utilization: Calif.

Water Pollution Control Board Pub., no. 18, 104 p., 1957.

The agricultural utilization of waste waters is described. 


\section{California Water Project Authority.}

Investigation of the Sacramento-San Joaquin delta: Calif. Water Proj. Authority, v. 2, 1956.

Volume 1 is on ground-water geology and volume 2 on water supply and water utilization on Medford Island.

California Water Resources Board.

1. Water utilization and requirements of California: Calif. Water Resources Board Bull., no. 2, 227 p., 1955.

The present use of water throughout California and the probable ultimate water requirement are determined. Appendixes and plates are in a separate volume.

2. Santa Clara Valley investigation: Calif. Water Resources Board Bull., no. 7, 154 p., 1955.

This is a comprehensive report on water supply, water utilization and supplemental requirements, plans for water development, and recommendations.

3. Placer County investigation: Calif. Water Resources Board Bull., no. 10, 270 p., 1955.

This is a comprehensive report on water supply, water utilization and supplemental requirements, plans for water development, and recommendations.

4. San Joaquin County investigation: Calif. Water Resources Board Bull., no. 11, 294 p., 1955.

This is a comprehensive report on water supply, water utilization and supplemental requirements, plans for water development, and conclusions.

5. Weather modification operations in California: Calif. Water Resources Board Bull., no. 16, 271 p., 1955.

The report includes theory of weather modification, history of operations in California, evaluation methods and evaluation of selected operations, and laws of California pertaining to weather modification. Results of the evaluations are not conclusive.

6. Floods of California, 1955: Calif. Water Resources Board, v. 1, illus., 1956.

7. The California water plan: Calif. Div. Resources Plan. Bull. no. 3, 246 p., 1957.

A master plan to guide and coordinate the planning and construction by all agencies of works required for the control, protection, conservation, and distribution of California's water resources.

Calkins, Robert S.

Engineering developments in watershed programs: Agr. Eng. v. 36, no. 11, p. 730-731, 1955.

The use of check dams and silt traps is described.

Callahan, Charles C.

Principles of water rights legislation in Ohio, with a preface by C. V. Youngquist:

Ohio Div. Water, 34 p., 1957.

Legal principles applicable to streams, to diffused surface waters, and to underground waters are given.

Callahan, J. T.

1. (and Cushman, R. L.). Geology and ground-water supplies of the Fort Wingate Indian School area, McKinley County, New Mexico: U.S. Geol. Survey Circ. 360, 12 p., 1955.

A study of local geology in relation to ground-water occurrence is described.

2. Ground water in Floyd County, Georgia: Georgia Mineral Newsletter, v. 11, no. 1, p. 16-18, 1958. 


\section{Callison, Charles H.}

America's natural resources: New York, Ronald Press Co., 1957.

The book consists of the contributions of 11 authors and has separate chapters on soil, water, grasslands, forests, wildlife, fish, parks and wildernesses, land-use principles, renewable resources and human populations, ecology, and natural resources policy.

Calvin, Lyle D. See Barton, M.

Camp, Fred A.

Sierra Nevada glacier measured: Civil Eng., v. 28, p. 34-35, Feb. 1958.

Palisade Glacier is described, and the acre-feet reduction in size over a 30 -year period is computed.

Camp, Thomas R. See O'Connor, D. J.; Stein, M.

Capen, Charles H. See Bergen, S. W.; Meyner, R. B.

Cardwell, G. T.

Geology and ground water in the Santa Rosa and Petaluma Valley areas, Sonoma

County, California: U.S. Geol. Survey Water-Supply Paper 1427, 273 p., 1958.

Geologic conditions are determined, an estimate of the gross storage capacity of the several ground-water basins is made, and factors bearing on the usability of the storage are considered. Many data are included.

Carey, Walter C.

(and Keller, M. Dean). Systematic changes in the beds of alluvial rivers: Am.

Soc. Civil Engineers Proc., v. 83, no. HY 4, Paper 1331, 24 p., 1957.

Sand-wave formations and their variation with respect to river stages are discussed. (Discussions by T. Blench, v. 84, no. HY 1, Paper 1558, p. 47-48, 1958; Vito A. Vanoni and Hsin-Kuan Liu, v. 84, no. HY 2, Paper 1616, p. 9-15, 1958; authors' closure, v. 84, no. HY 5, Paper 1832, p. 49-50, 1958.)

Cariño, Isidro D.

A graphical solution for flow in earth channels: Am. Soc. Civil Engineers Proc., v. 83, no. IR 2, Paper 1360, 9 p., 1957.

The solution utilizes Manning's formula for design of trapezoidal sections in earth. (Discussions by R. G. Cox, Steponas Kolupaila, John F. Kennedy, v. 84, no. IR 2, Paper 1615, p. 13-22, 1958, and author's closure, v. 84, no. IR 3, Paper 1784, p. 5, 1958.)

Carlson, Charles A.

(and Reinhart, K. G., and Horton, J. S.). Predicting moisture in the surface foot of the soil: Soil Sci. Soc. America Proc., v. 20, no. 3, p. 412-415, 1956.

The method described has given acceptable results when applied to the specific experimental sites from which the data were obtained.

Carlson, Enos J. See also Brooks, N. H.

(and Miller, Carl R.). Research needs in sediment hydraulics: Am. Soc. Civil Engineers Proc., v. 82, no. HY 2, Paper 953, 33 p., 1956.

Methods used for solution of sediment problems found by the Bureau of Reclamation are discussed. Research needed to improve these methods is suggested. (Discussions by Arthur I. McCutchan, Sam Shulits, v. 82, no. HY 5, Paper 1092, p. 19-22, 1956, and authors' closure, v. 83, no. HY 2, Paper 1230, p. 29-30, 1957.)

Carlston, Charles W.

Ground-water resources of Monongalia County, West Virginia: W. Va. Geol. and Economic Survey Bull. 15, 12 p., 1958. 
Carpenter, J. D.

What are the safe yields of Pennsylvania's water sources?: Water Works Eng., v. 110, no. 1, p. 61-62, 1957.

Rainfall-runoff relations, mass curves, and other factors are used in defining the safe yield.

Carreker, John R. See also van Bavel, C. H. M., 4.

Water in agriculture: Ga. Acad. Sci. Bull., v. 15, no. 3, p. 86-89, 1957.

The report describes the variability of rainfall, the crop production increases due to irrigation, and the increases in infiltration that accrue from crop-rotation practices.

Carstens, M. R. See Kindsvater, C. E., 2.

Carter, Douglas B. See also Thornthwaite, C. W., 4.

1. The water balance of the Lake Maracaibo basin during 1946-53: Lab. Climatology, Pubs. Climatology, v. 8, no. 3, 1955.

2. The water balance of the Mediterranean and Black Seas: Lab. Climatology, Pubs. Climatology, v. 9, no. 3, 1956.

3. The average water balance of the Delaware Basin: Lab. Climatology, Pubs. Climatology, v. 11, no. 3, 22 p., 1958.

Modification of the water balance approach for basins within the Delaware Valley.

Carter, R. F. See LeGrand, H. E., 2; Thomson, M. T., 1.

Carter, Rolland W. See also Kindsvater, C. E., 1, 2; Tracy, H. J., 1.

Computation of peak discharge at culverts: U.S. Geol. Survey Cire. 376, 25 p., 1957.

Methods for computing peak flood flow through culverts on the basis of a field survey of high-water marks and culvert geometry are presented.

Carter, Rufus H., Jr.

Control of arroyo floods at Albuquerque, New Mexico: Am. Soc. Civil Engineers Proc., v. 81, Paper 801, 8 p., 1955.

Flows of high discharge and short duration which flood valleys are discussed. Diversion channels are proposed to protect valuable land. (Discussion by Geary M. Allen, Jr., v. 82, no. WW 1, Paper 913, p. 13-14, 1956, and author's closure, v. 82, no. WW 4, Paper 1068, p. 5, 1956.)

Case, James B.

Mapping of glaciers in Alaska: Photogramm. Eng., v. 24, no. 5, p. 815-821, 1958. Experience indicates that aerial photogrammetry in most cases offers a more satisfactory solution to the mapping of glaciers than terrestrial photogrammetry.

Cass, Clyde P., Jr. See Herndon, L. W.

Cassidy, Willuam F. See also Morris, S. B., 1.

California's worst flood disaster: Mil. Engineer, v. 48, no. 322, p. 99-103, 1956.

The floods of December 1955 are described.

Causey, L. V. See Miller, J. D., Jr., 2.

Cavadias, George S.

1. (and Scruton, G. H.). Snow sampling experiment: Eastern Snow Conf. Proc., v. 3, p. 33-34, 1955.

Differences between water equivalents measured by Mount Rose and Adirondack samplers were found to be statistically nonsignificant.

2. Reappraisal of snow-melt as a factor in Quebec streamflow: Eastern Snow Conf. Proc., v. 3, p. 67-77, 1955. 
A forecasting equation relates freshet runoff to water content of snow, February mean river flow, precipitation during the freshet period, and evaporation losses. Details are given.

3. An approach to forecasting the spring runoff in Quebec: Western Snow Conf. Proc., p. 35-45, Apr. 1958.

The principal factor determining the volume of spring runoff is precipitation during the runoff period. Several variables were tested by multiple regression. Forecasting equations were derived for half-month periods.

Cederstrom, D. J.

Geology and ground-water resources of the York-James peninsula, Virginia: U.S.

Geol. Survey Water-Supply Paper 1361, 237 p., 1957.

The geologic formations and their water-bearing properties, ground-water quality, an artificial recharge experiment, and detailed information on the ground-water resources by counties are described.

Chamber of Commerce of the United States.

National water and power policy: U.S. Chamber Commerce, 36 p., 1956.

The report contains the speeches of 13 experts who appeared on the program of the National Conference on Water Resources Policy held at St. Louis, Mo., January 1956.

Chang, Jen-hu.

Global distribution of the annual range in soil temperature: Am. Geophys. Union Trans., v. 38, p. 718-723, 1957.

Maps of annual range in soil temperature at three depths, temperature-range profile charts, and depths of invariable temperature are given.

Changnon, S. A., JR. See also Huff, F. A., 8.

1. (and Huff, F. A.). Cloud distribution and correlation with precipitation in Illinois: Ill. Water Survey Rept. Inv. 33, 83 p., 1957.

Climatological descriptions of the frequency and amount of various cloud types were obtained. Means and extremes for monthly, seasonal, and annual periods were included. Diurnal patterns were established, and the relation between clouds and surface precipitation was investigated.

2. Thunderstorm-precipitation relations in Illinois: Ill. Water Survey Rept. Inv. 34,24 p., 1957.

The annual geographic distribution of thunderstorms and of thunderstorm precipitation are given. Occurrences by months are also shown. Information from cooperative substations supplemented the data from first-order stations.

Chapman, Cecil W.

Developing water rights legislation in Georgia: Jour. Soil and Water Conserv., v. 12 , no. 2 , p. $79-84,1957$.

Water problems and proposed legislation are described.

Chappelear, J. E.

An investigation of the solitary wave: Am. Geophys. Union Trans., v. 37, p. 726-734, 1956.

Two solutions are presented to the problem of calculating the velocity field within a solitary wave and its celerity and profile. Results of the two solutions are compared with experimental results.

Charaljavanaphet, Jumchet. See La Moreaux, P. E., 2. 
Chard, A. E.

Forecasting Powell Lake runoff: Western Snow Conf. Proc., p. 11-12, Apr. 1956. Snow-survey data, precipitation records, and long-range weather forecasts are used to forecast elevation of lake on June 30.

Chase, R. W.

California ground-water replenishment bill: Am. Water Works Assoc. Jour., v. 47, no. 4, p. 383-388, 1955.

This paper discusses a bill pending (1954) in the State legislature.

Chemical and Engineering News.

Carbon black controls clouds: Chem. and Eng. News, v. 36, no. 40, p. 67-68, 1958. Carbon black sprinkled from an airplane will dispel a cloud under certain conditions and in moist atmosphere may cause cloud formation.

Chien, Ning. See also Brooks, N. H.; Einstein, H. A., 1, 2.

1. The present status of research on sediment transport: Am. Soc. Civil Engineers Trans., v. 121, p. 833-868, 1956.

The problem of sediment transport has been examined briefly in this paper. The significance and implication of the various phases of the problem have been emphasized, controversial issues have been discussed, and efforts have been made to unify some of the highly diversified results. (Discussion by Thomas Blench, Jan M. Jordaan, Jr., Joe M. Lara, Navinchandra L. Rupani and John B. Stall, Hsin-Kuan Liu, and Ning Chien and Hans A. Einstein.)

2. Graphic design of alluvial channels: Am. Soc. Civil Engineers Trans., v. 121, p. 1267-1280, 1956.

The determination of channel depth and slope to conduct a specified unit discharge and sediment load is presented in graphical form on the basis of the Einstein bedload function. Applications of these curves are made. (Discussion by Thomas Blench and Emory W. Lane.)

3. A concept of the regime theory: Am. Soc. Civil Engineers Trans., v. 122, p. 785-793, 1957.

By using functional relationships between sediment characteristics and silt factors, the depth and slope of an alluvial channel in regime can be determined either by the bedload function or by the regime theory with little difference between the two. (Discussion by Gerald Lacey, Emory W. Lane, Thomas Blench, and Hans A. Einstein.)

Chiengmai, Phong Phan Na. See LaMoreaux, P. E., 2.

Childs, Eluiot F.

Northeastern floods of 1955; Flood control hydrology: Am. Soc. Civil Engineers Proc., v. 84, no. HY 3, Paper 1663, 24 p., 1958.

Meteorology and flood discharges and their effect on design criteria for floodcontrol structure are described. (Discussions by Gordon R. Williams, H. Alden Foster, v. 84, no. HY 6, Paper 1856, p. 91-94, 1958; Leo R. Beard, v. 85, no. HY 1, Paper 1919, p. 105-110, 1959; author's closure, v. 85, no. HY 6, Paper 2076, p. 63-65, 1959.)

\section{Chilingar, George V.}

1. Use of hydrochemistry and temperature of underground waters in petroleum exploration-a review: Am. Geophys. Union Trans., v. 36, p. 673-674, 1955.

Chemistry and temperature of underground waters appear to be useful tools in petroleum exploration.

2. Durov's classification of natural waters and chemical composition of atmos- 
pheric precipitation in U.S.S.R.-a review: Am. Geophys. Union Trans., v. 37, p. 193-196, 1956.

The review contains Durov's method of classifying natural waters on the basis of ionic composition. The ehemical composition of atmospheric precipitation in U.S.S.R. is also presented.

3. Soviet methods of reporting and displaying results of chemical analyses of natural waters and method of recognizing oil-field waters-a summary: Am. Geophys. Union Trans., v. 38, p. 219-221, 1957.

Chorley, Richard J.

(and Malm, Donald E. G., and Pogorzelski, Henry A.). A new standard for estimating drainage basin shape: Am. Jour. Sci., v. 255, no. 2, p. 138-141, 1957.

One loop of a lemniscate is suggested as a new standard.

Chow, Ven TE. See also Boyer, M. C., 1; Escoffier, F. F., 2; Langbein, W. B., 4; Liu, H. K., 3; Snyder, F. F., 2; Weiss, L. L., 2.

1. On the determination of frequency factor in log-probability plotting: Am. Geophys. Union Trans., v. 36, p. 481-486, 1955.

A revised procedure of transformation of the variate in the logarithmically normal probability distribution.

2. A note on the Manning formula: Am. Geophys. Union Trans., v. 36, p. 688, 1955.

The formula proposed by Manning does not have the same form as the one used today. (Discussions by Hunter Rouse, J. M. Robertson, James C. I. Dooge, and author's closure, v. 37 , p. $327-330,1956$.)

3. Frequency analysis in small watershed hydrology: Agr. Eng., v. 39, no. 4, p. 222-225, 1958.

This is a review of the theory and of the practical methods.

Christensen, R. P. See Colby, B. C.

Christian, N. L. See Hanson, E. L.

Chu, Henry Hsien. See Keifer, C. J.

Church, J. E. See Anderson, H. W., 2.

Churchill, Milo A.

Effects of storage impoundments on water quality: Am. Soc. Civil Engineers Trans., v. 123, p. 419-464, 1958.

Observations made on reservoir waters in Tennessee Valley are presented and summarized.

Ciriacy-Wantrup, S. V.

(and Smith, Stephen C.). Economics of California water development: Calif. Univ. Comm. Research Water Resources, 180 p., 1957.

Proceedings of a conference at Lake Arrowhead in August 1957. Papers are included on water development and economic growth, economic problems in water allocation, economics of project planning, and suggestions for economic research.

Clark, C. O. See Kohler, M. A., 4; Paulhus, J. L. H.

Clark, Edward J. See Hill, R. A.

CLARK, L. K.

(and Noble, E. L.). The Forest Service soil and water management program in the Intermountain Region: Soc. Am. Foresters Proc., p. 33-34, 1958.

A brief description is given. 
Clark, R. H.

Predicting the runoff from snowmelt: Eng. Jour., v. 38, no. 4, p. 434-441, 1955.

The author uses coaxial multiple graphical correlation for evaluating the effect of antecedent conditions, temperatures, and rainfall during the snowmelt period on the runoff from accumulated snowfall. Estimates for Red River by this method are fairly accurate. (Discussions by Norman Aspin and A. N. Andrew, and author's reply, v. 38, no. 9, p. 1216-1218, 1955).

Clark, Robert A.

(and Fonken, David W.). Design storms for Central Utah Project area between latitudes $40^{\circ} 00^{\prime}-40^{\circ} 52^{\prime}$ and longitudes $109^{\circ} 30^{\prime}-112^{\circ} 00^{\prime}$ : U.S. Bur. Reclamation, Div. Proj. Inv., 31 p., June 1958.

A map of mean annual precipitation and charts for determining design storm depths for various size areas and various durations are presented.

Chark, Robert H. See Snyder, F. F., 1.

Clark, William E.

Forecasting the dry-weather flow of Pond Creek, Oklahoma-a progress report: Am. Geophys. Union Trans., v. 37, p. 442-450, 1956.

Ground-water levels and temperature records are used to forecast dry-weather streamflow.

Cleary, Edward J. See also Hartung, H. O.

1. 9th annual summary, 1957; a report on the interstate crusade for clean streams: Ohio River Valley Water Sanitation Comm., 32 p., 1957.

2. (and Robertson, David A., Jr.). Ohio River water quality and flow: Am. Water Works Assoc. Jour., v. 50, no. 3, p. 399-409, 1958.

Methods used by the Ohio River Valley Water Sanitation Commission to obtain basic data on quality conditions and flow variations. (Correction, v. 50, no. 5, p. 620.)

3. Sleuthing the behavior of a river: Am. Soc. Civil Engineers Proc., v. 84, no. SA 6, Paper 1847, 17 p., 1958.

Seven years of surveillance and appraisal of quality conditions and flow variations of Ohio River are described. (Discussions by G. E. Walker, Bernd H. Dieterich, v. 85, no. SA 3, Paper 2044, p. 95-102, 1959; and author's closure, v. 85, no. SA 5, Paper 2181, p. 31, 1959.)

Cleasby, John L. See Baumann, E. E.

Clendenen, Frank B. See also Thomas, R. O., 1; Todd, D. K., 5.

Maximizing river-basin benefits by conjunctive operation of surface and groundwater reservoirs: Western Snow Conf. Proc., p. 9-15, Apr. 1957.

The benefits of conjunctive operation are described.

Cuinch, R. L.

(and Saaltink, H. J.). In the wake of Hurricane Hazel: Eng. Jour., v. 38, no. 8. p. 1057-1062, 1955.

The severe flooding in Ontario is described and recommendations are made for extension of basic data and for advisement of the public as to inherent damages,

Clyde, George D.

Water supply, water use, and its conservation: Utah State Univ. Agr. Expt. Sta. Circ. 38, 12 p., 1958.

An address given at the 71st annual meeting of the American Association of Land Grant Colleges and State Universities. 
Contes, D. R.

1. (and Cushman, R. L.). Geology and ground-water resources of the Douglas basin, Arizona, with a section on chemical quality of the ground water, by J. L. Hatchett: U.S. Geol. Survey Water-Supply Paper 1354, 56 p., 1955.

Geography, geology, occurrence and use of ground water, and ground-water quality are described.

2. Quantitative geomorphology of small drainage basins of southern Indiana: Columbia Univ. Dept. Geology Tech. Rept., no. 10, 67 p., 1958.

This paper reports an analysis of the geomorphic composition of stream-eroded topography of an unglaciated area and of the influences of lithology, stage of development, and available relief on the form properties.

Cochrane, N. J. See Blaney, H. F., 2, 4; Langbein, W. B., 6; Potter, W. D., 1.

Codp, A. R.

(and Work, R. A.). Establishing snow survey networks and snow courses for water supply forecasting: Western Snow Conf. Proc., p. 6-12, Apr. 1955.

The purposes to be served, the theory involved in snow sampling, and the value of the streamflow forecast are considered in the design. (Discussion by J. H. DoughtyDavies and F. M. Veatch.)

Code, W. E.

Water table fluctuations in eastern Colorado: Colo. Agr. Expt. Sta. Bull. 500-S, 34 p., 1958.

The report contains descriptions of the subareas and graphs of water levels in wells.

Cohen, Bernard.

Salinity of the Delaware estuary: Del. Geol. Survey Rept. Inv., no. 1, 86 p., 1957.

A factual account of salinity variations between Philadelphia and Reedy Point from July 1954 through December 1956.

Colbert, Jesse L. See Giles, G. C.

Colby, B. C

(and Christensen, R. P.). Visual accumulation tube for size analysis of sands:

Am. Soc. Civil Engineers Proc, v. 82, no. HY 3, Paper 1004, 17 p., 1956.

A method is presented for accurate determination of the fall-velocity distribution of sand samples.

Colby, B. R. See also Swenson, H. A.

1. (and Hembree, C. H.). Computations of total sediment discharge, Niobrara River near Cody, Nebraska: U.S. Geol. Survey Water-Supply Paper 1357, 187 p., 1955.

Sediment discharges were measured at a constricted section in which nearly the total sediment discharge was suspended, and at unconfined sections. Several formulas were used to compute total sediment discharge from data obtained at the unconfined sections, and the results were compared with the known sediment discharge at the constricted section.

2. (and Hembree, C. H., and Rainwater, F. H.). Sedimentation and chemical quality of surface waters in the Wind River basin, Wyoming: U.S. Geol. Survey Water-Supply Paper 1373, 336 p., 1956.

This report gives results of an investigation to determine the quantity of sediment transported by streams in the basin and the chemical quality of the waters. Results are needed to evaluate plans for irrigation development.

3. Relationship of unmeasured sediment discharge to mean velocity: Am. Geophys. Union Trans., v. 38, p. 708-717, 1957. 
Unmeasured sediment discharges increase as a function of about the third power of the mean velocity. At constant mean velocity, the unmeasured sediment discharge per foot of width generally increases with the concentration. Applications of these relationships are given.

Colcord, J. E.

The TAF phototheodolite and its use in glacier surveys: Photogramm. Eng., v. 23, no. 3 , p. 552-557, 1957.

The instrument and its use are described.

Coldwell, Albert E.

Importance of channel erosion as a source of sediment: Am. Geophys. Union Trans., v. 38, p. 908-912, 1957.

A specific statement is not possible on the percentage of total erosion caused by channel erosion. Bank erosion may be a greater part of the total erosion in a watershed than was previously supposed.

Cole, J. A. See De Jong, G. de J.

Cole, R. C.

Water quality criteria in planning and operating projects of the Bureau of Reclamation: Conf. Quality Water Irrig., Davis, Calif., 1958, Proc., Contr. 14, sec. 2, p. 33-39.

Collier, Charles R. See also Lamar, W. L., 2.

(and Krieger, R. A.). Quality of surface waters of Kentucky, 1953-55: Ky. Dept. Economic Devel., 219 p., 1958.

Chemical analyses, specific conductance, suspended sediment, and water temperatures are given.

Collins, Arthur L. See Petersen, J. S.

Colman, E. A. See also Ackermann, W. C., 2; Rowe, P. B., 4; Veihmeyer, F. J., 1. Watershed management opportunities in the West [abs.]: Western Snow Conf. Proc., p. 1-2, Apr. 1955.

The water-yielding lands are mostly uncultivated. Four types in California are described.

Commission on Organization of the Executive Branch of the Government.

Water resources and power: Washington, U.S. Govt. Printing Office, 124 p., 1955. Report of the Commission to the Congress.

Conkuin, Howard L.

1. Water requirements of the carbon-black industry: U.S. Geol. Survey Water-

Supply Paper 1330-B, p. 73-100, 1956.

Two methods of manufacture are described and the water requirements (quantity and quality) of each are given.

2. Water requirements of the aluminum industry: U.S. Geol. Survey WaterSupply Paper 1330-C, p. 103-139, 1956.

Manufacturing processes are described and the water requirements given.

Conkling, Harold. See Kazmann, R. G., 2.

Connecticut Water Resources Commission.

Water resources of Connecticut: Water Resources Comm., 200 p., 1957.

A report to the General Assembly describing water resources, present and future requirements, water problems of various groups, and water law.

Conner, N. W. See Long, L. W.

Conner, W. C.

(and Kraft, R. H., and Harris, D. L.). Empirical methods for forecasting the 
maximum storm tide due to hurricanes and other tropical storms: Monthly Weather Rev., v. 85, no. 4, p. 113-116, 1957.

An empirical relation between the extreme tide due to a hurricane and the hurricane's central pressure is presented. It is stated that this one parameter can account for approximately half of the total variability of the storm surge on the open coast.

ConNor, J. G.

(and Mitchell, C. G.). A compilation of chemical quality data for ground and surface waters in Utah: Utah State Engineer Tech. Pub. 10, 276 p., 1958.

Conover, C. S.

Ground-water conditions in the Rincon and Mesilla Valleys and adjacent areas in New Mexico: U.S. Geol. Survey Water-Supply Paper 1230, 200 p., 1954 [1955]. Purpose of the investigation was to determine the amount of ground water available for supplementing the surface-water supply for irrigation. The aquifers, the various sources of recharge, and the ways ground water is discharged are described. Ground water obtained by pumping is not a new supply but rather a change in method, time, and place of diversion of already available supplies.

Conover, L. F. See Hiser, H. W., $2,4$.

Cook, Frank A.

Near surface soil temperature measurements at Resolute Bay, Northwest Territories: Arctic, v. 8, no. 4, p. 237-249, 1955.

This paper presents near surface soil-temperature data, and generalizations on soil temperature and moisture content and migration based on these data.

Соок, JонN C.

Some observations in a northwest Greenland crevasse: Am. Geophys. Union Trans., v. 37, p. 715-718, 1956.

A description and the changes observed during 2 months are given.

Cooper, Alfred J.

(and Snyder, Willard M.). Evaluating effects of land-use changes on sediment load: Am. Soc. Civil Engineers Proc., v. 82, no. HY 1, Paper 883, 14 p., 1956. Effects of land-use changes on suspended sediment-load characteristics of tributary watersheds are evaluated by multiple-regression analysis.

Copeland, Otis L., Jr.

Watershed management in research-soil survey needs: U.S. Forest Service Watershed Management Conf. Northern Region Proc., 106 p., 1956.

Needs for and interpretation and utilization of soil survey information in relation to watershed management and other activities are discussed.

Copeland, William R.

Fresh water from sea water for 8.4 cents per 1,000 gallons?: Water Works Eng., v. 108 , no. 5 , p. $422,1955$.

Recent developments in desalting practices are summarized.

Conbetr, D. M. See Perrey, J. I., 2.

Conbetr, W. H. See Benedict, P. C., 1.

Corey, A. T.

Measurement of water and air permeability in unsaturated soil: Soil Sci. Soc. America Proc., v. 21, no. 1, p. 7-10, 1957.

This paper describes how a controlled pressure, steady state method developed for 
making measurements on oil-producing rocks may be adapted for determining water and air permeabilities in unsaturated soils. Results of measurements on a loamy sand are given.

Corey, Gilbert L. See Blaney, H. F., 1.

Corker, C. E. See Kuder, W. B.

Corn, Herbert M. See also Huff, F. A., 4.

Rainfall depth-duration relationships: Am. Soc. Civil Engineers Proc., v. 81, Paper 840, 14 p., 1955.

Relationships of storm depths, duration, and patterns are considered. The method of analysis indicates that most short-time intense precipitations behave according to rigorous physical laws. Analyses of particular storms are made. (Discussion by D. M. Hershfield and W. T. Wilson, v. 82 , no. HY 2, Paper 955, p. 61-66, 1956; author's closure, v. 82, no. HY 5, Paper 1092, p. 15-18, 1956.)

Соттол, C. A.

New Zealand geomorphology; Reprints of selected papers, 1912-1925: New York, Hafner Publishing Co., 281 p., 1955.

Contains 16 papers dealing with the geomorphology of New Zealand and also illustrating the principles of geomorphology.

Council of State Governments.

1. Reports on water resources, 1956 and 1957: Chicago, Ill., Council State Govts., 17 p., 1957.

An annotated bibliography of recent official reports of State agencies.

2. State administration of water resources: Chicago, Ill., Council State Govts., 153 p., 1957.

The role of the States is primarily regulatory. The diversity of State water-resource programs reflects varying needs and demands. In general several agencies within a State carry on water programs. Recommendations for revising organizations and expanding duties are made.

Counts, Harlan B.

1. Ground-water resources in a part of southwestern Arkansas: Ark. Geol. and Conserv. Comm. Water Resources Circ. 2, 35 p., 1955.

2. Ground-water resources of parts of Lonoke, Prairie, and White Counties, Arkansas: Ark. Geol. and Conserv. Comm. Water Resources Circ. 5, 65 p., 1957.

Court, Arnold.

1. Wind direction during snowfall at Central Sierra Snow Laboratory: Western Snow Conf. Proc., p. 39-43, Apr. 1957.

Wind direction is important in understanding the manner in which snow accumulates. Direction was found to be predominantly southwesterly at the laboratory. 2. Selection of "best" snow course points: Western Snow Conf. Proc., p. 1-11, Apr. 1958.

Five measurements should be enough to characterize the water content of a snow course. The median of these five should be almost as good an index as the mean. These hypotheses were tested and verified by analyzing data from a 19-point snow course. (Discussion by C. G. Wolfe and J. F. Hannaford.)

Cover, Winton. See Halstead, M. H.

Cowan, Woody L. See also Ford, E. C.

Estimating hydraulic roughness coefficients: Agr. Eng., v. 37, no. 7, p. 473-475, 1956. 
The procedure involves selection of a basic value of $n$ for a straight, uniform, smooth channel and then the modification of this value for five factors. The modifying values given may not apply to channels having hydraulic radii greater than 15 feet.

Cowley, W. R. See Bloodworth, M. E., 1, 2.

Cowlin, R. W.

Pulp mills are thirsty: Western Conserv. Jour., v. 12, no. 4, p. 16-17, 21, 1955.

Continued expansion of the pulp industry in the Pacific Northwest is dependent upon abundant supplies of clear water. The report shows the importance of forested watersheds in that regard, and it outlines a watershed management program.

Cox, Joel B. See Boreli, M.

Cox, Maurice $\mathrm{B}$.

Rainfall-runoff relations on wheatland: Agr. Eng., v. 37, no. 2, p. 117-119, 1956.

A 12-year record of rainfall and runoff from a 7.85-acre plot is analyzed.

Cox, R. G. See Cariño, I. D.

Coyle, D. C.

Conservation, and American story of accomplishment: New Brunswick, N.J., Rutgers Univ. Press, 284 p., 1957.

The history of conservation in United States is traced from colonial days to present with emphasis on events since 1900 . Conservation of forests, soil, water (including flood control and power), fuels, minerals, and wildlife are treated.

Coyle, J. J. See Blakely, B. D.

CrabB, G. A., JR. See Smith, J. L.

Craddock, George W.

1. Status of present knowledge and present watershed research program of the Intermountain Station: U.S. Forest Service Watershed Management Conf. Northern Region Proc., 106 p., 1956.

Discusses and illustrates kinds of knowledge developed in watershed management and its application.

2. Watershed management problems of the Intermountain West: Soc. Am. Foresters Proc., p. 31-32, 1958.

Watershed restoration, prevention of watershed deterioration, and improvement of water yields are the general problems.

Craig, Franklin C. See Ingerson, I. M.

Craig, Harmon.

1. Proceedings, conference on new research methods in hydrology, Scripps Institution of Oceanography, La Jolla, California, Feb. 2-3, 1957: Calif. Univ. Comm. Research Water Resources, 37 p., 1957.

Purpose was (1) to draw attention of hydrologists to new tools for hydrologic studies which have been developed by physical and nuclear chemists and (2) to expose the laboratory scientists to comments and criticisms of seasoned fieldworkers in hydrology and ground-water geology. Lengthy abstracts of papers and summaries of discussions are given.

2. Proceedings, conference on recent research in climatology, Scripps Institution of Oceanography, La Jolla, California, Mar. 25-26, 1957: Calif. Univ. Comm. Research Water Resources Center Contr. 8, 121 p., 1957.

Fifteen papers and a lecture are included. 
Craine, Lyle E. See Duke University School of Law.

Cramer, John W. See Bechert, C. H.

Crawford, C. B.

(and Legget, R. F.). Ground temperature investigations in Canada: Eng. Jour., v. 40, no. 3, p. 263-269, 1957.

A program to determine ground temperature variations geographically and with depth in Canada is described.

Crawford, Ivan C.

1. Colorado's water resources: Colo. Water Conserv. Board, 39 p., 1956.

2. Water resource planning in Colorado: Colo. Water Conserv. Board, 76 p., 1957. The report presents the pathway followed by the State of Colorado in its waterresource development programs from the middle of the last century to the present.

Cressey, George B.

1. Water in the desert: Annals Assoc. Am. Geographers, v. 47, no. 2, p. 105-124, 1957.

This paper discussed land and water, desert criteria, competition for water, hydrology in dry lands, salt, silt, ground water, desert prospects, kanats, and geographic inventory. Illustrations and examples are from the Middle East. 2. Quanats, karez, and foggaras: Geog. Rev., v. 48, no. 1, p. 27-44, 1958.

These underground infiltration tunnels or "horizontal wells" provide an important source of water supply in southwest Asia and north Africa. Methods of construction, economic considerations, and distribution are covered.

Criddle, Wayne D. See also Fox, R. L.

1. Consumptive studies provide information on amount of water needed by various areas: Utah State Expt. Sta., Farm and Home Sci., v. 16, no. 1, p. 17-18, 1955.

2. (and Davis, Sterling, Pair, Claude H., and Shockley, Dell G.). Methods for evaluating irrigation systems: U.S. Dept. Agriculture, Agriculture Handb. No. 82, 24 p., Apr. 1956.

The evaluation methods described should permit greater efficiency in irrigation and should lead to better design criteria.

3. Methods of computing consumptive use of water: Am. Soc. Civil Engineers Proc., v. 84, no. IR 1, Paper 1507, 27 p., 1958.

Generally-used methods for computing the consumptive water requirements of crops and charts to simplify the application of these methods are presented. (Discussions by Robert O. Thomas, v. 84, no. IR 2, Paper 1615, p. 35-37, 1958; Harry F. Blaney, v. 84, no. IR 3, Paper 1784, p. 33-36, 1958; and author's closure, v. 85 , no. IR 1 , Paper 1986 , p. 73,1959 .)

4. Consumptive use and irrigation water requirements of Milford Valley, Utah:

Utah Agr. Expt. Sta., ARS 41-14, 45 p., 1958.

A determination of unit consumptive use rates for individual crops and an inventory of all water supplies and their uses within the valley are given.

5. Utah's future water problems: Utah State Univ. Mon. ser., v. 6, no. 2, 19 p., 1958.

A faculty honor lecture describing the history of water-resources development in Utah, future uses and problems, and research in water use and development.

Criner, James $\mathrm{H}$.

(and Armstrong, Clarence A.). Ground-water supply of the Memphis area: U.S. 
Geol. Survey Circ. 408, 20 p., 1958.

An area of about 1,000 square miles was studied.

Criner, James H., Jr. See Onellion, F. E., 1.

Crisler, Robert Malcolm, Jr. See Priddy, R. R., 1.

Critchlow, Howard T.

Water rights in humid areas: Am. Soc. Civil Engineers Proc., v. 81, Separate 705, 8 p., 1955.

Information on the legal control of water and on irrigation practice in 31 States east of the 100th meridian is given. (Discussions by H. E. Thomas, C. E. Busby, Paul H. Berg, and J. C. Alexander, v. 82, no. IR 1, Paper 903, p. 3-8, 1956; and author's closure, v. 82, no. IR 3, Paper 1111, p. 3-4, 1956.)

Croft, A. R. See Rosa, J. M., 2; Salmond, G. R.; Veihmeyer, F. J., 1.

Cronin, James G.

(and Newport, Thomas G.). Ground-water resources of the Ainsworth unit, Cherry and Brown Counties, Nebraska, with a section on chemical quality of ground water, by Robert A. Krieger: U.S. Geol. Survey Water-Supply Paper 1371, 120 p., 1956.

The Ainsworth unit is a 1,000 -square-mile area in north-central Nebraska in the drainage basin of Niobrara River.

Crooke, Howard W.

A method of financing ground water replenishment: Am. Soc. Civil Engineers Proc., v. 84, no. IR 4, Paper 1860, 14 p., 1958.

A dual tax structure is used in Orange County, Calif. Legal and practical procedures are outlined.

Crosthwaite, E. G. See also Littleton, R. T.

1. (and Scott, R. C.). Ground water in the North Side Pumping Division, Minidoka, Project, Minidoka County, Idaho: U.S. Geol. Survey Circ. 371, 20 p., 1956.

This paper reports an investigation of the probable effects of the proposed irrigation of 64,000 acres with ground water.

2. Ground-water possibilities south of the Snake River between Twin Falls and Pocatello, Idaho: U.S. Geol. Survey Water-Supply Paper 1460-C, p. 99-145, 1957.

A preliminary appraisal is made of ground-water resources in relation to land resources and to the regimen of surface streams.

Crowley, Claude D.

Cheaper, simpler hooded inlets for small ponds are easily installed: Land Improvement, v. 4, no. 11, p. 8-9, Nov. 1957.

A hooded inlet that can be installed for 30 percent less than the cost of the conventional trickle tube or drop inlet spillway, and that will give satisfactory drainage is described.

Cruse, Robert R. See Beadle, B. W.

Cunningham, M. B. See Bergen, S. W.

Curran, Brother Henry M.

Fresh water extracted from salt water; Is the freezing method the best?: Texas Univ. Bur. Eng. Research, 12 p., 1955.

Currie, B. W. See Kendrew, W. G. 


\section{CURRY, JoHN J.}

Connecticut Flood Planning Session, II-Application to dams: Conn. Soc. Civil Engineers, 73d ann. rept., p. 93-97, 1957.

The historical development of regulations for the safety of dams in Connecticut and the reasons for acceptance of the frequency concept as a design basis are given.

Cushman, R. L. See also Callahan, J. T., 1; Coates, D. R., 1.

(and Halpenny, L. C.). Effect of western drought on the water resources of Safford Valley, Arizona, 1940-52: Am. Geophys. Union Trans., v. 36, p. 87-94, 1955.

An unusually wet period, 1940-41, was followed by a drought period, 1942-52. The effect of the drought was delayed and reduced because of the wet period. Withdrawals of ground water for supplemental irrigation supply lowered well levels sufficiently to reduce yields. Concentration of dissolved mineral matter increased in the remaining ground water.

Dale, James A.

Automatic VHF radio telemetering of hydrologic data: Am. Soc. Civil Engineers Proc., v. 83, no. HY 3, Paper 1278, 17 p., 1957.

The operation, equipment, and costs are described for an automatic radio-gage system for obtaining rainfall and stream-level data.

Dale, Robert F.

1. The climate of the Matanuska Valley: U.S. Weather Bur. Tech. Paper, no. 27, 26 p., 1956.

Text and tables summarize the climatological characteristics of this Alaskan valley.

2. Mechanization of the processing of climatological data: Western Snow Conf. Proc., p. 35-38, Apr. 1957.

Practices and experiences of the U.S. Weather Bureau are described.

Dale, Tom.

For insurance against drought—-soil and water conservation: U.S. Dept. Agriculture, Farmers Bull., no. 2002, 22 p., 1958.

A well-planned soil and water conservation program helps prevent damage from drought.

Dalla Valle, J. M.

Coagulation and sedimentation: Am. Soc. Civil Engineers Proc., v. 82, no. HY 4, Paper 1052, 11 p., 1956.

A theoretical development is made.

Dalrymple, Tate.

Northeastern floods of 1955: Rainfall and runoff: Am. Soc. Civil Engineers Proc., v. 84, no. HY 3, Paper 1662, 19 p., 1958.

Peak discharges at selected sites and the causative rainfalls are listed. The relation to past floods is shown, and some indication of the frequency presented. (Discussion by Howard M. Turner, v. 84, no. HY 7, Paper 1880, p. 5-15, 1958; and author's closure, v. 85, no. HY 5, Paper 2045, p. 181, 1959.)

Daniels, Warren S. See also Larson, B. O.

(and Hale, Malcolm D.). Floods of October 1954 in the Chicago area, Illinois and

Indiana: U.S. Geol. Survey Water-Supply Paper 1370-B, p. 107-200, 1958.

Detailed records of stage, discharge, and other pertinent data for the flood period are furnished. A section on flood frequency of the area and on flood-crest stages is included. The floods were the greatest in the history of the Chicago area.

Danielson, R. E. See Russell, M. B. 
Darling, H. Velpeau.

The Mekong Basin, an engineer's view: Mil. Engineer, v. 49, no. 330, p. 266-269, 1957.

A brief description of topography, climate, and hydrology of the basin is given.

Daubenmire, R.

Influence of temperature upon soil moisture constants and its possible ecologic significance: Ecology, v. 38, p. 320-324, 1957.

Influences of temperature on water-holding capacity, moisture equivalent, and wilting coefficient were obtained from experiments. It is suggested that temperature effects may help explain diurnal variations in streamflow.

Davis, Albert R. See Bechert, C. H.

Davis, Clarence A.

Our national water resources policy: Am. Water Works Assoc. Jour., v. 47, no. 9, p. 827-832, 1955.

Some of the water problems of the country are discussed.

Davis, Dan A. See Wentworth, C. K.

Davis, E. K. See Kuder, W. B.

Davis, G. H. See also Poland, J. F., 1.

(and Poland, J. F.). Ground-water conditions in the Mendota-Huron area, Fresno and Kings Counties, California: U.S. Geol. Survey Water-Supply Paper 1360-G, p. 409-588, 1957.

This report presents and briefly interprets available data on ground-water occurrence and development in the area; the change in water levels that has occurred in response to heavy pumping; the general magnitude of recharge; the general magnitude of overdraft or the water being mined; and the general chemical quality of the ground water, with special reference to recharge possibilities.

Davis, JoHn R.

1. Future of irrigation in humid areas: Am. Water Works Assoc. Jour., v. 48, no. 8, p. 982-990, 1956.

Potential water requirements for irrigation should be planned for now.

2. Evaporation and evapotranspiration research in the United States and other countries: Am. Soc. Agr. Engineers, 87 p., 1957.

These reports include work in 13 countries, not including Russia, Israel, and Mexico. Descriptions include present status of project, cooperating agencies, results, and available publications.

Davis, K. C.

(and Meek, John F.). Economics of ground-water development on farms in southwest Oklahoma: Okla. Agr. Expt. Sta. Bull. B-499, 30 p., 1957.

Davis, Leon V.

Geology and ground-water resources of Grady and northern Stephens Counties, Oklahoma: Okla. Geol. Survey Bull. 73, 184 p., 1955.

Davis, RoBert T.

Report on snow surveyors training conference at Alta, Utah: Western Snow Conf. Proc., p. 39-42, Apr. 1956.

This is a brief report.

Davis, Sterling. See Criddle, W. D., 2.

Day, E. K. See Fournelle, H. J. 
Day, John A. See also Decker, F. W.

Cloud seeding; hope or hoax: Water and Sewage Works, v. 105, no. 5, p. 207-209, 1958.

The development, theory, and practice of cloud seeding and the need for further research are described.

Dar, Paul R. See also Luthin, J. N.

1. Dispersion of a moving salt-water boundary advancing through saturated sand: Am. Geophys. Union Trans., v. 37, p. 595-601, 1956.

The mathematical treatment is based upon a statistical theory developed by Scheidegger. Equations are derived for the dispersion of salt water injected into the stream. The mechanism is referred to as hydrodynamic dispersion. The theory was tested in the laboratory.

2. (and Luthin, James N.). A numerical solution of the differential equation of flow for a vertical drainage problem: Soil Sci. Soc. America Proc., v. 20, no. 3, p. 443-447, 1956.

Richards' differential equation of flow, which furnished the theoretical basis, can be solved numerically by finite differences. An illustration and an experimental test are given.

3. (and Forsythe, Warren M.). Hydrodynamic dispersion of solutes in the soil moisture stream: Soil Sci. Soc. America Proc., v. 21, no. 5, p. 477-480, 1957.

The results of an experiment, supported by theory, indicate that the amount of dispersion of a thin layer of fluid traversing a thin column of soil to a depth $L$ is proportional to the square root of the distance traversed, and it is independent of the time-rate of displacement.

Dean, Willatad W.

Helicopters-from the fieldman's standpoint: Western Snow Conf. Proc., p. 71-72, Apr. 1957.

The use of helicopters for snow surveying is described.

DeBuchananne, G. D.

(and Richardson, R. M.). Ground-water resources of east Tennessee: Tenn. Div. Geology Bull. 58, pt. 1, 393 p., 1956.

This report describes the ground-water resources of an area of about 10,000 square miles in east Tennessee.

Decker, Fred W. See also Berry, F. A.

(and Lincoln, Russell L., and Day, John A.). Analysis of cloud seeding efforts in the Tri-county area, Oregon, 1950-54: Am. Meteorol. Soc. Bull., v. 38, no. 3, p. 134-137, 1957.

Based on a multiple-regression equation to compute natural rainfall, it was concluded that commercial cloud seeding failed to produce statistically significant departures in precipitation. (Discussion by F. A. Berry and Gerald D. Berndt, v. 38 , no. 8 , p. 497,1957 .)

Decker, John P.

(and Wetzel, Barton F.). A method of measuring transpiration of intact plants under controlled light, humidity, and temperature: Forest Sci., v. 3, no. 4, p. $350-354,1957$.

A laboratory method is described. Transpiration rate increased as light intensity and temperature increased and as humidity decreased.

Deere, Don U. See Hadley, R. F. 
DeGrove, JohN M.

Approaches to water resource development in central and southern Florida, 1845-

1947: Fla. Univ.Public Adm. Clearing Service Studies Public Adm., no. 17, 54 p., 1958.

A review and objective analysis of this developmental period are given.

Dehlinger, Peter.

(and Bundrant, C. O.). Flow of gel and oil in open and tight formation fractures: Am. Geophys. Union Trans., v. 36, p. 624-632, 1955.

Flow characteristics of different oils and gels were investigated using porous ceramic bricks. Relative advantages of oil and gel in formation treatments are discussed.

De Jong, G. de Josselin.

Longitudinal and transverse diffusion in granular deposits: Am. Geophys. Union Trans., v. 39, p. 67-74, 1958.

Probability computations, based on certain assumptions, lead to explicit values for the coefficients of longitudinal and transverse diffusion. A test device is used to determine longitudinal diffusivity. The test result and theory are compared. (Discussion by J. A. Cole, and author's closure, v. 39, p. 1160-1162, 1958.)

De Jong, Tim.

An introduction to solar distillation: Am. Soc. Civil Engineers Proc., v. 84, no. SA 4, Paper 1704, 40 p., 1958.

Results of experiments on the production of potable water with solar energy at three pilot plants in Iran are given.

Delleur, J. W.

The boundary layer development in open channels: Am. Soc. Civil Engineers Proc., v. 83, no. EM 1, Paper 1138, 24 p., 1957.

Development of a turbulent boundary layer is analyzed theoretically for the case of steady flow in a horizontal open channel. Theoretical and experimental results are compared. (Discussions by T. Blench, v. 83, no. EM 3, Paper 1311, p. 7-8, 1957; Yoshiaki Iwasa, Alfred C. Ingersoll, Masashi Hom-ma; and author's closure, v. 84, no. EM 1, Paper 1520, p. 3-22, 1958.)

DeLong, George C. See Koeppe, C. E.

Denison, P. J.

(and Power, B. A.). Precipitation forecasting during the snow-melt period: Eastern Snow Conf. Proc., v. 3, p. 78-92, 1955.

The general problem of long-range weather forecasting is discussed.

Dennis, Arnett S.

Some possible effects of seeding convective clouds: Western Snow Conf. Proc., p. 77-78, Apr. 1957.

The sequence of events leading to precipitation from a cumulus cloud and possible effects of silver-iodide seeding are given.

de Percin, Fernand. See Meigs, P.

DePlater, C. V.

A portable capacitance-type soil moisture meter: Soil Sci., v. 80, no. 5, p. 391-395, 1955.

A portable meter designed for use with a probe rapidly determines soil moisture in terms of electrical capacitance.

Depman, A. J. See Rasmussen, W. C., 4. 


\section{Derby, Ray L.}

Water use in industry: Am. Soc. Civil Engineers Proc., v. 83, no. IR 2, Paper 1364, 9 p., 1957.

Quantity and quality requirements, economics of reuse, and use of waste waters are discussed. (Discussion by Frederick L. Hotes; and author's closure, v. 84, no. IR 3, Paper 1784, p. 17-21, 1958.

Deutsch, Morris. See also Vanlier, K. E., 1, 2.

1. Effects of dissemination of radioactive materials on water resource conservation with special reference to Michigan: Mich. State Univ., Dept. Resource Devel. Water Bull. 2, 35 p., 1956.

Background activities of water must be known before effects of dissemination of artificially produced radioelements on the hydrologic cycle can be appraised.

2. (and Burt, E. M., and Vanlier, K. E.). Summary of ground-water investigations in the Holland area, Michigan: Mich. Geol. Survey Div. Rept., no. 20, 87 p., 1958.

A compilation and an interpretation of data are presented on the source, occurrence, availability, and chemical quality of ground water.

DE VRIES, D. A. See also Philip, J. R., 1; Woodside, W.

Simultaneous transfer of heat and moisture in porous media: Am. Geophys. Union Trans., v. 39, p. 909-916, 1958.

Generalized simultaneous differential equations are developed.

Dexheimer, W. A.

Multiple-use projects in development of water resources: Am. Soc. Civil Engineers Proc., v. 84, no. IR 3, Paper 1752, 6 p., 1958.

Increasing the usable water supply requires cooperative and multiple-purpose planning.

Diachishin, Alex N. See Niles, T. M.; O'Connor, D. J.

\section{Diamond, Marvin.}

Precipitation trends in Greenland during the past 30 years: U.S. SIPRE Research Rept., no. 22, 4 p., 1956.

The record of annual precipitation is obtained from stratigraphic studies on snow profiles.

Diebold, C. H.

Irrigated soils . . . water intake is key to success: Crops and Soils, v. 8, no. 4, p. 14-15, 29, Jan. 1956.

The water intake rate on many soils can be increased above present levels and more profit derived from the land.

Dieterich, Bernd H. See Cleary, E. J., 3.

Dils, RoBert E. See also Johnson, E. A., 1.

1. (and Arend, John L.). Snow accumulation under red pine of different stand densities in Lower Michigan: U.S. Forest Service, Lake States Forest Expt. Sta. Tech. Note 460, 2 p., 1956.

Measurements show that depth of snow accumulation decreased as stand density increased.

2. A guide to the Coweeta Hydrologic Laboratory: U.S. Forest Service, Southeastern Forest Expt. Sta. Booklet, 40 p., 1957.

Installations, program, and some results of 23 years of watershed research are described. 
Dingle, A. Nelison.

Patterns of change of precipitation in the United States: Jour. Meteorology, v. 12, no. 3, p. 220-225, 1955.

A study of precipitation records for individual stations, smoothed by decadal moving averages, suggests that prominent trends are continuous in time and space. A preliminary synoptic study of the interdecadal changes of average precipitation reveals details of the circulation changes in regard to cyclonic activity and moisture supply.

Dingman, R. J.

1. (and Gordon, E. D.). Geology and ground-water resources of the Fort Berthold Indian Reservation, North Dakota, with a section on chemical quality of the ground water, by H. A. Swenson: U.S. Geol. Survey Water-Supply Paper 1259,113 p., 1954 [1955].

This report describes the ground-water yields from the various geologic formations in the area. Both yield and water quality are highly variable.

2. (and Ferguson, H. F., and Martin, Robert O. R.). The water resources of Baltimore and Harford Counties: Md. Dept. Geology, Mines, and Water Resources Bull. 17, 233 p., 1956.

The report contains a section on ground water and one on surface water.

Disney, L. P.

Tide heights along the coasts of the United States: Am. Soc. Civil Engineers Proc., v. 81, Separate 666, 9 p., 1955.

Highest and lowest tides recorded at several stations are listed. The yearly and secular variations in sea level for some stations are shown.

Dittbrenner, Erhard E. See Langbein, W. B., 4.

Dobbins, William E. See O'Connor, D. J.

Doland, James J. See Babbitt, H. E.

Dомву, C. W.

(and Kohnke, Helmut). The effect of freezing and thawing on structure of the soil surface: Agronomy Jour., v. 47, no. 4, p. 175-177, 1955.

Investigations of the structure of the surface inch of soil over a period of 2 years showed that the greatest changes occurred during alternate freezing and thawing. The movements of moisture during these changes are described.

Domingo, Clifford E. See Nelson, C. E.

Dominitz, JАCK. See Benton, G. S.

Doneen, L. D. See also Veihmeyer, F. J., 1.

Proceedings, conference on quality of water for irrigation: Calif. Univ. Water Resources Center Contr., no. 14, 206 p., 1958.

Several papers are included under each of the following: (1) Quality of water program, (2) water quality criteria, (3) quality considerations of irrigation water for a permanent agriculture, (4) problems of quality control of California waters, and (5) water quality in relation to irrigation practice.

Donn, Willitam L.

(and Ewing, Maurice). Stokes' edge waves in Lake Michigan: Science, v. 124, no. 3234, p. 1238-1242, 1956.

The theory of edge waves appears to explain most of the recorded effects of the storm surge of July 6-7, 1954, in Lake Michigan. 
Donnan, William W. See Haise, H. R., 2.

Donnelly, Charles A. See Blaisdell, F. W.

Dooge, James C. I. See Chow, V. T., 2.

DorRoH, JoHN H., JR.

Beneficial use of water in arid lands: The Future of Arid Lands, p. 156-160, Am. Assoc. Adv. Sci., 1956.

Attention and research should be directed toward ways of changing the use of water on our natural watersheds from nonbeneficial to beneficial.

Dortignac, E. J.

1. Watershed resources and problems of the Upper Rio Grande Basin: Rocky Mtn. Forest and Range Expt. Sta., 107 p., 1956.

Comprehensive analyses are given of problems related to water, soil, forage, timber, wildlife, ownership patterns, and economic social development in the basin. The report contains 11 colored maps.

2. Water yields through watershed management in New Mexico: N. Mex. Water Conf. Proc. 1956, p. 69-97, 1957.

The following topics are discussed: The relation between precipitation and runoff by climatic and vegetation zones in New Mexico, the opportunity for improving water yields through management on the basis of research findings, and the need for additional research information for guiding and improving watershed-management practices.

Doss, B. D.

(and Broadfoot, W. M.). Properties of 91 southern soil series: U.S. Forest Service, Southern Forest Expt. Sta. Oecasional Paper 147, 16 p., 1956.

Tabular summaries are presented of soil properties determined in conjunction with work of the Vicksburg Infiltration Project.

Doughty-Davies, J. H. See Codd, A. R.

Douglass, John B.

(and Gay, Henry R., Todd, A. R., and Wright, Bern). Eastern water shortage and drought problems; conditions in West Virginia: Am. Water Works Assoc. Jour., v. 47, no. 3, p. 213-222, 1955.

Dover, T. B.

(and Geurin, J. W.). Summary of annual records of chemical quality of water of the Arkansas River in Oklahoma and Arkansas, 1945-52: U.S. Geol. Survey Circ. 361, 20 p., 1955.

The Arkansas River is subject to many types of pollution. The quality of water is described by river reaches.

Downing, H. T. See Malmberg, G. T.

Doyel, William W. See Winslow, A. G., 2.

Drake, Paul G. See Lamar, W. L., 1.

Dreibelbis, F. R. See Harold L. L., 7; King, K. M.; Remson, I., 3.

Drescher, William J. See also Harder, A. H.

1. Some effects of precipitation on ground water in Wisconsin: Wis. Geol. and Nat. History Survey Circ., no. 1, 17 p., 1955.

Graphs of precipitation and water level in wells show the relation between the two.

2. Ground water in Wisconsin: Wis. Geol. and Nat. History Survey Circ., no. 3, 37 p., 1956. 
A general description of the occurrence, source, movement, and use of ground water in Wisconsin. The need for evaluation of the potential supply is shown.

Drew, J. V.

(and Tedrow, J. C. F., Shanks, R. E., and Koranda, J. J.). Rate and depth of thaw in arctic soils: Am. Geophys. Union Trans., v. 39, p. 697-701, 1958.

Measurements at Point Barrow, Alaska, indicate that the rate and depth of thaw in arctic soils are related to soil type. Dominant vegetation also changes with soil type.

Drinkwater, W. O.

(and James, B. E.). Relation of potential evapotranspiration to environment and kind of plant: Am. Geophys. Union Trans., v. 38, p. 524-528, 1957.

Potential evapotranspiration was found to vary with type of plant and between uniform and nonuniform surroundings. High correlations were found between measured potential evapotranspiration and weather data for between-rain periods only. (Discussions by M. A. Kohler and Edgar E. Foster; and author's closure, v. 39 , p. $972-974,1958$.)

Dufford, Alvin E.

Quaternary geology and ground-water resources of Kansas River valley between Bonner Springs and Lawrence, Kansas: Kans. Geol. Survey Bull. 130, 96 p., 1958.

Kansas River valley alluvium, the only source of abundant ground-water supplies in the area, produced more than $\mathbf{2 . 6 5}$ million gallons per day of ground water of fair quality in 1953. Adequate supplies are available for future expansion. The report contains geologic maps, profiles, and tables of well records and chemical analyses.

Duke Untversity School of Law.

Water resources [Durham, N. C.]: Law and Contemporary Problems, v. 22, no. 3, p. 323-537, 1957.

The author and the title of the paper that he presented at the symposium follow: Ernest A. Englebert, "Federalism and Water Resources Development"; Roscoe C. Martin, "The Tennessee Valley Authority: A study of federal control"; Lyle E. Craine, "The Muskingum Watershed Conservancy District: A Study of Local Control"; Robert J. Morgan, "The Small Watershed Program"; Roy E. Huffman, "The Role of Private Enterprise in Water Resources Development"; James W. Fesler, "National Water Resources Administration"; Irving K. Fox, "National Water Resources Policy Issues"; Henry C. Hart, "Crisis, Community, and Consent in Water Politics."

Dunford, E. G. See also Brown, H. E.

1. (and Weitzman, Sidney). Managing forests to control soil erosion, in U.S. Department of Agriculture, Water: Yearbook of Agriculture 1955, p. 235-242.

The report contains discussion of factors causing erosion on forest and rangelands and suggestions for controlling soil disturbance resulting from road building, logging, grazing, and fire.

2. A watershed research program for the Pacific Northwest: Soc. Am. Foresters Proc., p. 190-195, 1955.

Physical characteristics, water needs, watershed uses, watershed problems needing research, and a proposed research program are described. 
3. Watershed management research in the Pacific Northwest: Jour. Soil and Water Conserv., v. 13, no. 1, p. 23-26, 1958.

Seven research projects are described.

DUNKLe, RoBert V.

(and Bevans, J. T.). An approximate analysis of the solar reflectance and transmittance of a snow cover: Jour. Meteorology, v. 13, no. 2, p. 212-216, 1956.

An analysis is made of the transmission and reflection of a mathematical model approximating a snow cover. The model has not yet been tested experimentally.

Dunning, H. N. See Johansen, R. T.

Durfor, C. $\mathrm{N}$.

(and Keighton, W. B.). Chemical characteristics of Delaware River water, Trenton, New Jersey to Marcus Hook, Pennsylvania: U.S. Geol. Survey WaterSupply Paper 1262, 173 p., 1954 [1955].

This progress report gives the results of an investigation from August 1949 to December 1952.

Durum, Walton H. See Rapp, J. R.; Swenson, F. A., 1.

DusenberRy, H. L.

(and Monson, O. W.). Measuring devices for irrigation water: Mont. State Coll., Ext. Ser. Bull., no. 289, 19 p., 1956.

Dwyer, Carroll $\mathrm{H}$.

The economics of water supply forecasting: Western Snow Conf. Proc., p. 63-66, Apr. 1958.

Monetary terms can be placed on the value of water-supply forecasts.

Dyrness, C. T.

(and Youngberg, C. T., and Ruth, Robert H.). Some effects of logging and slash burning on physical soil properties in the Corvallis watershed: U.S. Forest Service, Pacific Northwest Forest and Range Expt. Sta. Research Paper 19, 15 p., 1957.

Physical properties of soil in undisturbed, disturbed-unburned, and lightly burned parts of clearcuts remained closely similar to those under adjacent timber stands. Only on the severely burned part (8 percent of the area) was the surface soil seriously affected.

Eardley, A. J.

(and Gvosdesky, Vasyl, and Marsell, R. E.). Hydrology of Lake Bonneville and sediments and soils of its basin: Geol. Soc. America Bull., v. 68, p. 1141-1201, 1957.

Information on precipitation changes and lake-level fluctuations of Great Salt Lake are included.

EARLe, J. B.

Land use changes in the Southeast: Soil Conserv., v. 22, no. 5, p. 117-119, 1956.

Land use has changed from cotton to grass and trees.

Eckstein, Отто.

Water resource development: Cambridge, Mass., Harvard Univ. Press, 300 p., 1958.

An analysis is given of the procedures for measuring benefits and costs employed by the U.S. Bureau of Reclamation and the Corps of Engineers, U.S. Army. The study is concerned with the economics of the four largest water-resource programs: flood control, navigation, irrigation, and electric power. 
Eddards, M. L.

(and Kister, L. R., and Scarcia, Glenn). Water resources of the New Orleans area, Louisiana: U.S. Geol. Survey Circ. 374, 41 p., 1956.

Water resources and present water utilization are described.

Edminster, Talcott W. See Frevert, R. K.

Edstrand, John P.

Missouri River main stem reservoirs: Mil. Engineer, v. 48, no. 321, p. 25-29, 1956.

The reservoirs and the dams are described.

Edwards, D. H.

Water tables, equipotentials, and streamlines in drained soil with anisotropic permeability: Soil Sci., v. 81, no. 1, p. 3-18, 1956.

Two-dimensional steady-state drainage problems are investigated by the method of electric analogues for a soil whose permeability is anisotropic. For the two cases of anisotropy studied, it is shown (1) how the height of the water table varies with rate of rainfall for a particular drain diameter, (2) the manner in which the drain diameter is related to water-table height for a given rainfall, and (3) how an impermeable bed below the drains influences the flow. Results are compared with published results for isotropic soils.

Eichmeier, A. H. See Ash, A. S.

EILER, JACK P. See Wolman, M. G., 2.

Ernstein, Hans A. See also Blench, T.; Brooks, N. H.; Chien, N., 1, 3.

1. (and Chien, Ning). Effects of heavy-sediment concentration near the bed on the velocity and sediment distribution: Calif. Univ. Inst. Eng. Research, M. R. D. Sediment Ser., no. 8, Aug. 1955.

It is imperative that the effects of heavy-sediment concentration near the bed on both the velocity and sediment distribution be considered and, if possible, incorporated into the theories on sediment transport.

2. (and Chien, Ning). Similarity of distorted river models with movable beds: Am. Soc. Civil Engineers Trans., v. 121, p. 440-457, 1956.

The similarity conditions for distorted river models with movable beds are derived from the theoretical and empirical equations which describe the hydraulics and the sediment transport in such rivers. A complete numerical example is used to demonstrate the method of application to a particular river. (Discussion by Thomas Blench.)

3. (and Johnson, J. W.). Proceedings, conference on sediment problems in California, Berkeley, California, Nov. 26-27, 1956: Calif. Univ. Comm. Research Water Resources, 142 p., 1956.

Several papers are included under each of the following: (1) Current research in California, (2) river and reservoir problems, and (3) coastal and tidal problems.

4. (and Li, Huon). Secondary currents in straight channels: Am. Geophys. Union Trans., v. 39, p. 1085-1088, 1958.

The existence of straight uniform flows without secondary current is studied. The conditions are given under which such flows can occur. (Discussion by C. J. Posey and R. W. Powell, Jour. Geophys. Research, v. 64, p. 861-862, 1959.)

Eisenstadt, Raymond. See Hadley, W. A.

Eley, G. W. See Quackenbush, T. H.

Eliassen, Rolf.

(and Lauderdale, Robert A.). Radioactive fallout in water supply at Portland,

Maine: Am. Water Works Assoc. Jour., v. 48, no. 6, p. 665-670, 1956. 
A description of the analytical procedures and a discussion of the results are given.

ELliotT, RoBert D.

The Santa Barbara randomized cloud seeding program: Western Snow Conf. Proc., p. 73-76, Apr. 1957.

A cooperative program for evaluating the effect of cloud seeding on precipitation is described.

Elis, Harold H.

(and Bausman, R. O.). Some legal aspects of water use in Delaware: Del. Eng. Expt. Sta. Bull., no. 314, 37 p., 1955.

The riparian doctrine is apparently in effect, but laws need clarification.

EuLIS, J. D.

The optimum use of water for power calculated by Datatron electronic computer:

Western Snow Conf. Proc., p. 53-58, Apr. 1958.

The computer, the steps in setting up a program, and the savings over hand calculation are described. (Discussion by David M. Rockwood.)

Elmendorf, Harold B. See Fletcher, H. C.

Errick, D. E. See Bourget, S. J.

Engel, F. V. A. See Kandaswamy, P. K.

ENGINEERING NEws-Record.

1. Havoc in Australia, huge floods inundate large areas in New South Wales: Eng. News-Rec., v. 154, no. 11, p. 44, Mar. 17, 1955.

The unprecedented floods are described.

2. Tributary flash floods create major disaster: Eng. News-Rec., v. 155, no. 8, p. 21-23, Aug. 25, 1955.

Hurricane floods of August 1955 in Northeastern United States are described.

3. \$100-million floods strike Western States: Eng. News-Rec., v. 156, no. 1, p. 26-27, Jan. 5, 1956.

A brief description of the floods.

4. River control affects water supplies: Eng. News-Rec., v. 156, no. 3, p. 41-42, Jan. 19, 1956.

Regulation of the Missouri River poses problems for communities using the river for water supply.

5. Eisenhower unveils water policy: Eng. News-Rec., v. 156, no. 4, p. 21-22, Jan. 26, 1956.

Proposals for modernizing and coordinating federal water-resources policies are made.

6. Skimming fresh water off salt: Eng. News-Rec., v. 156, no. 11, p. 47, Mar. 15, 1956.

Use of a horizontal collection tunnel in Hawaii.

7. World group discusses weather modification: Eng. News-Rec., v. 156, no. 20, p. 103-106, May 17, 1956.

Claims for and against the effectiveness of cloud seeding are given.

8. Evaporation losses: Eng. News-Rec., v. 156, no. 20, p. 106, May 17, 1956.

A brief statement is made of research on monomolecular films for evaporation suppression.

9. What to do about a 10-year drought: Eng. News-Rec., v. 158, no. 4, p. 43-44, Jan. 24, 1957.

A survey of conditions in south-central United States is reported. 
10. Fresh from salt at $\$ 0.42$ per 1,000 gallons: Eng. News-Rec., v. 158 , no. 7 , p. 59, Feb. 14, 1957.

A description of an electric membrane method is given.

11. States face up to water rights problem: Eng. News-Rec., v. 158, no. 19, p. 23-26, May 9, 1957.

A survey of water-rights laws in 48 States was made.

12. Water resources techniques and trends; toward unity among developers: Eng. News-Rec., v. 160, no. 7, p. 205-217, Feb. 13, 1958.

A report on development policy and procedures during 1957 is presented.

13. Flood control system nurses runoff: Eng. News-Rec., v. 160, no. 10, p. 47-48, Mar. 6, 1958.

Flood control and ground-water recharge are accomplished by dispersing flood waters.

14. State pioneers flood plain zoning: Eng. News-Rec., v. 160, no. 21, p. 45-48, May 22, 1958.

The methods used by Connecticut are described.

15. Low cost seen for desalting sea water: Eng. News-Rec., v. 161, no. 5, p. 44, July $31,1958$.

Cost of four processes are given.

16. Snow pack gaging goes modern: Eng. News-Rec., v. 161, no. 18, p. 43, Oct. $30,1958$.

Data can be taken and transmitted by radiation and radiotelemetering methods respectively.

17. Columbia Basin plan; what it means: Eng. News-Rec., v. 161, no. 25, p. 23-24, Dec. 18, 1958.

The plan of the Corps of Engineers is described.

Englebert, Ernest A. See Duke University School of Law.

ENGLehardT, Wolf von.

(and Tunn, W. L. M.). The flow of fluids through sandstones [a translation from

German, by Paul A. Witherspoon]: Ill. Geol. Survey Circ. 194, 16 p., 1955.

Results of experiments on sandstones with 1 to 5 percent clay show that the Darcy equation does not hold for water and salt solutions which flow more slowly than would be predicted from their viscosity and the air permeability. An explanation is given.

Engler, Kyle. See Bartholomew, R. P.

Erdei, Joseph F. See Hatcher, M. P.

ERICKSON, Harold D.

Artesian conditions in northeastern South Dakota: S. Dak. Geol. Survey Rept. Inv. 77, 39 p., 1955.

Eriksson, Erik.

A note on the dispersion of a salt-water boundary moving through saturated sand:

Am. Geophys. Union Trans., v. 39, p. 937-938, 1958.

This paper criticizes a recent work on this subject.

Erlich, Harry. See McGauhey, P. H., 2.

Erskine, H. M.

Losses due to ice storage in Heart River, North Dakota: Am. Soc. Civil Engineers Proc., v. 83, no. HY 3, Paper 1261, 17 p., 1957.

Water losses due to ice storage in the channel are given for various rates of flow. 
EsChNer, A. R.

(and Jones, B. O., and Moyle, R. C.). Physical properties of 134 soils in six Northeastern States: U.S. Forest Service, Northeastern Forest Expt. Sta. Paper 89, 11 p., 1957.

Texture, organic-matter content, bulk density, plasticity, and soil-moisture constants are listed.

Escoffier, Francis F.

1. Transition profiles in nonuniform channels: Am. Soc. Civil Engineers Proc., v. 82, no. HY 3, Paper 1006, 19 p., 1956.'

The concept of the transition profile as a theoretical tool for the study of watersurface profiles is developed. A practical method of constructing a transition profile is given. (Discussions by Achille Lazard, v. 82, no. HY 5, Paper 1092, p. 23-25, 1956; L. J. Tison, and author's closure, v. 83, no. HY 2, Paper 1230, p. 31-40, 1957.) 2. Graphical determination of water-surface profiles: Am. Soc. Civil Engineers Proc., v. 82, no. HY 6, Paper 1114, 13 p., 1956.

This paper presents a graphical method which facilitates use of Bresse and Bakhmeteff tabular functions in estimating water-surface profiles in uniform channels. (Discussion by Ven Te Chow, v. 83, no. HY 2, Paper 1230, p. 63-65, 1957; and author's closure, v. 83, no. HY 5, Paper 1417, p. 7-8, 1957.)

Etringer, M. B. See Ludzack, F. J., 1, 2.

Evans, Norman A.

Stratum survey techniques for drainage investigation on irrigated lands: Colo. State Univ. Expt. Sta. Tech. Bull. 67, 19 p., 1958.

The theory and use of the geophysical method are discussed in detail. Techniques and equipment needed for three boring methods are also described.

Everts, Curtiss M., Jr.

Water quality depends on good forest management: Soc. Am. Foresters Proc., p. 199-201, 1955.

Proper logging practices can maintain water quality.

Ewing, Maurice. See Donn, W. L.

Fader, Stuart W.

1. An analysis of contour maps of water levels in wells in southwestern Louisiana; 1954: La. Geol. Survey Water Resources Pamph., no. 2, 11 p., 1955.

2. An analysis of contour maps of 1955 water levels, with a discussion of salt-water problems in south-western Louisiana: La. Geol. Survey Water Resources Pamph., no. 4, 27 p., 1957.

3. Water levels and water-level contour maps for southwestern Louisiana, 1956 and spring 1957: La. Geol. Survey Water Resources Pamph., no. 5, 23 p., 1958.

Report contains mostly data, but it includes graphs of water-table elevations from 1945-57.

FAIR, Gordon M.

(and Geyer, John C.). Elements of water supply and waste-water disposal: New York, John Wiley and Sons, 615 p., 1958.

The text is intended for undergraduate students. The chapters on hydrology, collection of surface water, and collection of ground water should be of interest to hydrologists.

FANG, H. Y. See Johnson, R. W.

Farrell, J. P. See Nash, J. E., 1. 
FATHY, A.

(and Shukry, Aly S.). The problem of reservoir capacity for long-term storage:

Am. Soc. Civil Engineers Proc., v. 82, no. HY 5, Paper 1082, 27 p., 1956.

A method is suggested for the systematic analysis of hydrologic data to define fully the capacity-yield relation for long-term storage. (Discussions by Mikhail S. Hanna, M. Gamal Mostafa, Y. M. Simaika, N. Boulos, v. 83, no. HY 2, Paper 1230, p. 51-61, 1957; Harold Edwin Hurst, v. 83, no. HY 3, Paper 1283, p. 3-6, 1957; and authors' closure, v. 83 , no. HY 6, Paper 1456, p. 7-9, 1957.)

Fenwick, G. B.

Large-scale flume at Waterways Experiment Station: Civil Eng., v. 26, p. 43, Jan. 1956.

The flume is 600 feet long, 125 feet wide, and is filled with sand to simulate a movable-bed channel.

Ferguson, George E. See also Parker, G. G., 2.

The Missouri River-Water quality and quantity: Am. Water Works Assoc. Jour., v. 48, no. 8, p. 951-962, 1956.

A general description is given of the surface and ground water resources and of the chemical quality of the water.

Ferguson, H. F. See Dingman, R. J., 2.

Ferris, J. G. See Kazmann, R. G., 1.

Fesler, James W. See Duke University School of Law.

Fiedler, Albert G.

Importance of ground water in the national economy: Am. Soc. Civil Engineers Trans., v. 123, p. 776-791, 1958.

Ground water is an important resource. There is no national ground-water problem, but there are numerous widely scattered problem areas. Typical problems in six areas are reviewed, and the solution of each must rest on adequate knowledge of the character and capacity of the ground-water reservoirs involved and on comprehensive planning.

Field, William O.

Atlas of mountain glaciers in the Northern Hemisphere: Am. Geog. Soc., Dept. Explor. and Field Research, 55 p., June 1958.

Forty-eight maps show in detail the distribution of mountain glaciers of the Northern Hemisphere.

Fireman, Milton. See Gardner, W. R., 3.

Fischerstrom, N. Clates H. See Bloodgood, D. E.

Fish, R. E. See also Billingsley, G. A.

(and LeGrand, H. E., and Billingsley, G. A.). Water resources of the Yadkin-

Pee Dee River basin, North Carolina: U.S. Geol. Survey Water-Supply Paper 1415, 115 p., 1957.

The occurrence, quality, and present use of surface and ground water are described.

Fishel, V. C.

1. (and Leonard, Alvin R.). Geology and ground-water resources of Jewell County, Kansas: Kans. Geol. Survey Bull. 115 [Univ. of Kans. Pub.] 152 p., 1955.

The geography and geology are described in general; and the occurrence, movement, utilization, and chemical character of the ground water are described in some detail. 
2. Long-term trends of ground-water levels in the United States: Am. Geophys. Union Trans., v. 37, p. 429-435, 1956.

Several long records of water levels are given. The levels, in general, are correlated with precipitation.

3. (and Mason, Betty J.). Ground-water levels in observation wells in Kansas, 1956: Kans. Geol. Survey Bull. 125, 158 p., 1957.

The report contains mostly data, but includes some graphs of water-level fluctuations.

Flack, J. E. See Li, W. H., 2.

Flack, J. Earnest. See Morris, S. B., 3.

Flaxman, Elliott M.

(and Hobba, Robert L.). Some factors affecting rates of sedimentation in the

Columbia River basin: Am. Geophys. Union Trans., v. 36, p. 293-303, 1955.

A stock-pond sedimentation survey revealed that five factors account for most of variation in sedimentation. These factors are the amount of land subject to accelerated erosion, original pond capacity per square mile of watershed, age of pond, size of watershed, and amount of annual precipitation. (Discussion by Harold E. Thomas; and author's closure, v. 37, p. 110-112, 1956.)

Fleming, Robert J., Jr.

1. (and Renshaw, Clarence). Operation Noah: Mil. Engineer, v. 47, no. 320, p. $424-428,1955$.

The report describes the emergency work of the Corps of Engineers following the New England floods of August 1955 and the effect of reservoir regulation.

2. Control of New England floods: New England Water Works Assoc. Jour., v. 71, no. 3, p. 234-242, 1957.

Major floods in New England and methods of control are discussed.

Fletcher, Herbert C.

(and Elmendorf, Harold B.). Phreatophytes-a serious problem in the West, in U.S. Department of Agriculture, Water: Yearbook of Agriculture 1955, p. $423-429$.

Eradication of phreatophytes will allow salvage of at least part of the water they used. Experimental methods of eradication are described.

Fletcher, P. W.

(and McDermott, R. E.). Moisture depletion by forest cover on a seasonally saturated Ozark Ridge soil: Soil Sci. Soc. America Proc., v. 21, no. 5, p. 547-550, 1957.

Flat-topped ridges have a subsoil pan horizon 2 to 4 feet below the surface which limits root penetration and water movement. Records of wells in forested and deforested areas indicate that evapotranspiration from the forested area was 0.175 inch of water daily during rainless periods in April and May.

Flora, SNowden D.

Hailstorms of the United States: Norman, Okla., Okla. Univ. Press, 201 p., 1956. This book concerns losses from hailstorms, oddities, the cause of hailstorms, forecasting, insurance, and hazards in the individual States, and in other countries.

Florey, Q. L. See also Timblin, L. O., Jr., 2.

The lid's on evaporation. Reclamation Era, v. 44, no. 3, p. 69-72, Aug. 1958.

A general discussion of use of hexadecanol to reduce evaporation and a description 
of the test program currently undertaken by the Bureau of Reclamation are presented.

Florida Board of Conservation.

Information on excessive rainfalls in Florida: Fla. Div. Water Survey and Research Paper, no. 13, 56 p., 1955.

The report contains information on major storm rainfalls, probable maximum rainfalls in central and southern Florida, maximum recorded rainfalls, and frequencies of short and intense rainfalls.

Florida Department of Water Resources.

Legislation for water resources in Florida: Fla. Dept. Water Resources Memo. Rept. 2, 1958.

Florida Enginening and Industrial Experiment Station.

An engineering conference on water management in Florida, proceedings of the 8th Municipal and Public Health Engineering Conference, March 15, 16, 1955 : Fla. Eng. and Indus. Expt. Sta. Bull. 72, 96 p., 1955.

Report contains 19 papers on legal implications, water requirements and resources, salt-water encroachment, water conservation and reclamation, and management practices.

Florida Water Resources Study Commission.

Florida's water resources: Fla. Water Resources Study Comm., 94 p., 1956.

A study was made of the physical, administrative, and legal aspects of water problems and water management, as related to agricultural, industrial, municipal, and recreational uses.

Floyd, Billy L. See Cagle, J. W., Jr.

Folletr, C. R.

Water-level decline maps, 1956 to 1957, and water levels in observation wells in

20 counties in the southern High Plains, Texas: Texas Board Water Engineers Bull. 5705, 41 p., 1957.

Fonken, David W. See Clark, R. A.

Foote, Lours H.

The Columbia River controlled: Am. Soc. Civil Engineers Proc., v. 84, no. WW 1, Paper 1514, 20 p., 1958.

U.S. Army Corps of Engineers plans of 1948 for development have been changed to meet changed conditions and needs. These changes and problems in water-resource development are outlined. (Discussion by Roy F. Bessey, v. 84, no. WW 3, Paper 1653, p. 11-16, 1958; and author's closure, v. 84, no. WW 5, Paper 1884, p. 3, 1958.)

Ford, ERwin C. See also Weinberger, M. L.

(and Cowan, Woody L., and Holtan, H. N.). Floods-and a program to alleviate them, in U.S. Department of Agriculture, Water: Yearbook of Agriculture 1955, p. 171-176.

This paper describes the factors that influence the size of floods and the interrelated threefold program of land treatment, upstream waterflow retardation, and downstream flood-control measures to alleviate floods.

Ford, Perry M. See Koelzer, V. A., 1.

Forester, Don M. See Goodrich, R. D.

Forrest, L. A. See van Bavel, C. H. M., 5. 
Forrest, T. CARr, Jr.

Water problems in Texas: Am. Water Works Assoc. Jour., v. 50, no. 9, p. 11571160, 1958.

Evaporation, variable rainfall, increased use, and overdevelopment in some areas are factors that cause a water shortage.

Forsythe, Warren M. See Day, P. R., 3.

Fosberg, M. A. See Jordan, J. V.

Foster, Albert B.

(and Fox, Adrian C.). Teaching soil and water conservation-a classroom and field guide: U.S. Dept. Agriculture PA-341, 30 p., 1957.

A guide intended for teachers.

Foster, Edgar E. See Drinkwater, W. O.

Foster, H. Alden. See also Adams, H. W., 1; Childs, E. F.; Gilman, C. S.; Todd, D. K., 7.

1. Technical problems of flood insurance: Am. Soc. Civil Engineers Proc., v. 83, no. HY 1, Paper 1165, 12 p., 1957.

Flood insurance is outlined from the engineering standpoint with emphasis on determining flood probability, estimating mean annual damage, spreading the risk over a large number of policies, and technical problems of setting up a program. (Discussions by G. N. Alexander and Steponas Kolupaila, v. 83, no. HY 4, Paper 1348, p. 15-19, 1957; and author's closure, v. 83, no. HY 6, Paper 1456, p. 11-12, 1957.)

2. Flood insurance: Mil. Engineer, v. 49, no. 329, p. 208-210, 1957.

Flood probability, insurance companies' views, and Federal flood insurance are discussed.

Foster, John W. See also Amsbary, F. C., Jr.

Groundwater geology of Lee and Whiteside Counties, Illinois: III. Geol. Survey Rept. Inv. 194, 67 p., 1956.

This report describes the occurrence, water-yielding characteristics, and drilling conditions of the important formations.

Fournelle, Harold J.

(and Day, E. K., and Page, W. B.). Experimental ground water pollution at Anchorage, Alaska: Public Health Repts., v. 72, no. 3, p. 203-209, 1957.

Fowler, Lloyd C. See also McCain, E. H.; Schroeder, K. B.

Determination of location and rate of growth of delta formations: U.S. Army Corps Engineers, Missouri River Div., Sediment Memo., no. 6, 13 p., Nov. 1957.

The report presents an equation for suspended sediment, suggesting a simple ratio of suspended sediment concentration at any point in backwater reach to that of the open river, which ratio can be used to approximate the rate of growth, location, and volume of delta formation in a reservoir.

Fox, Adrain C. See Foster, A. B.

Fox, G. S. See Remson, I., 1, 3.

Fox, Inving K. See Duke University School of Law.

Fox, Lester.

Our farmland has stopped flooding: Rural New Yorker, p. 2, July 19, 1958.

Controlling the Pequest River with a successful watershed program, North Jersey farmers have taken the fear out of rainfall-and put water to work. 
Fox, Roy L.

(and Phelan, John T., and Criddle, Wayne D.). Design of subirrigation systems: Agr. Eng., v. 37, no. 2, p. 103-107, 1956.

Design features, requirements, advantages, and disadvantages are described.

Fox, W. E. See Kohler, M. A., 1.

Franceschini, Guy A.

A method for determining the average precipitation between curved isohyets: Am. Geophys. Union Trans., v. 39, p. 273-277, 1958.

The method is described and a nomogram presented.

Francis, C. J.

How to control a gully, in U.S. Department of Agriculture, Soil: Yearbook of Agriculture 1957, p. 315-320.

A system for disposing of water is essential to prevent gully formation.

Frank, Bernard. See also Veihmeyer, F. J., 1.

The story of water as the story of man, in U.S. Department of Agriculture, Water: Yearbook of Agriculture 1955, p. 1-8.

Man's development and the growth and expansion of human civilizations have been markedly influenced and controlled by the availability of water. With increasing populations and declining water supplies of suitable quality for man's use, problems are developing which will require all of man's ingenuity to solve.

Franzini, Joseph B. See also Linsley, R. K., Jr., 1.

Permeameter wall effect: Am. Geophys. Union Trans., v. 37, p. 735-737, 1956.

Care must be exercised in interpreting results so as to account for the wall effect.

Frederickson, Don G.

Use of snow survey data by Soil Conservation districts: Western Snow Conf. Proc., p. 32-35, Apr. 1958.

Uses in southern Idaho are described.

Fredine, C. Gordon. See Shaw, S. P.

French, John L. See Li, W. H., 2.

French, Robert R.

(and Henley, Laurel M., Weatherford, Richard L., and Larson, Thurston E.). State agency programs for monitoring radioactivity in Illinois: Am. Water Works Assoc. Jour., v. 50, no. 7, p. 859-864, 1958.

Programs of the Department of Public Health and the Water Survey Division are described.

Frevert, Rrchard K. See also Timmons, J. F.

(and Schwab, Glenn O., Edminster, Talcott W., and Barnes, Kenneth K.). Soil and water conservation engineering: New York, John Wiley and Sons, 479 p., 1955.

This book describes the effects of precipitation, infiltration, evaporation, transpiration, and runoff. Means of reducing wind and water erosion are considered on a technical basis that shows the safety factors to be used. Need for irrigation, and equipment required, land clearing, and legal aspects are also covered.

Friedman, Don G.

(and Janes, Byron E.). Estimation of rainfall probabilities: Conn. Agr. Expt. Sta. Bull. 322, 22 p., 1957. 
Friedrich, C. Allan.

Fire on the watersheds of the nation, in U.S. Department of Agriculture, Water: Yearbook of Agriculture, p. 185-191, 1955.

Severe wildfires provide conditions favorable for devastating flash floods. Controlled burning may improve vegetation and watershed values.

Fritz, Sigmund.

Solar energy on clear and cloudy days: Sci. Monthly, v. 84, no. 2, p. 55-65, 1957. Fairly good engineering approximations of the solar energy received at the ground can be made for a cloudless atmosphere. The effect of clouds must be handled by empirical relationships using cloud-amount indexes.

Fry, Albert S.

Effects of major river basin development on watershed improvement: Jour. Soil and Water Conserv., v. 12, no. 2, p. 65-70, 1957.

The accomplishments of TVA in river-basin developments and watershed improvement are described.

FSIWA Committee on Research.

1. A critical review of the literature of 1955 on water pollution: Sewage and Indus. Wastes, v. 28, no. 6, p. 731-756, 1956.

Report gives summaries of findings and includes an extensive bibliography.

2. A review of the literature of 1956 on water pollution: Sewage and Indus. Wastes, v. 29, no. 7, p. 727-756, 1957.

Report gives summaries of findings and includes an extensive bibliography.

Fuhrman, Ralph E.

Our dwindling clean water supply: Water and Sewage Works, v. 102, no. 4, p. 143-145, 1955.

How water shortages affect municipal and industrial expansion.

Fukuda, Hitoshi.

Underdrainage into ditches in soil overlying an impervious substratum: Am. Geophys. Union Trans., v. 38, p. 730-739, 1957.

Theoretical equations are derived for the quantity of water seeping into equallyspaced ditches. Several of the equations are tested and found in agreement with experimental results.

Furcron, A. S. See LeGrand, H. E., 2.

Furness, L. W.

1. Floods in Nebraska, magnitude and frequency: Nebr. Dept. Roads and Irrig. Rept., 103 p., 1955.

This report contains a comprehensive summary of the magnitude and frequency of past floods and a means of estimating the expectancy of floods in the future at both gaged and ungaged sites. Annual peak stages and discharges at 97 gaging stations are included.

2. Development of a balanced stream-gaging program for Kansas: Kans. Water Resources Board Bull., no. 4, 50 p., 1957.

The report describes the design of a program which uses long-term and short-term stations and partial-record sites, and which should provide optimum information for the cost. Development is based on a statistical study of streamflow relationships.

GaffNeY, P. C.

Water; Preliminary economic considerations of the Arizona Watershed Program: 
2d Ann. Mtg. Ariz.Watershed Management Div., Ariz.Water Resources Comm., 71 p., 1958.

Seventeen papers given at the second annual meeting.

Galbraith, W. A.

Water resources policy for the State of Washington: Am. Water Works Assoc. Jour., v. 47, no. 10, p. 987-988, 1955.

This paper describes a committee-recommended water policy.

Gallatin, M. H. See Lunin, J.; Wadleigh, C. H.

Gamage, L. A. See Hosler, C. L.

Gandolfo, Jose S. See Lane, E. W., 2.

GARDE, R. J. See Laursen, E. M., 1.

Gardner, Charles, Jr.

Hauling down more water from the sky, in U.S. Department of Agriculture, Water: Yearbook of Agriculture 1955, p. 91-95.

This is a general description of attempted weather modification and the problem of evaluating its effectiveness.

GARDNER, W. H.

(and Hsieh, J. C.). Water velocity in unsaturated porous materials: Soil Sci. Soc. America Proc., v. 20, no. 2, p. 157-161, 1956.

Direct measurements of velocity in materials simulating soils are used with moisture density measurements to obtain the rate of flow. Velocity data are being used to study the mechanies of flow under unsaturated conditions.

GardNer, W. R. See also Richards, L. A., 2.

1. (and Mayhugh, M. S.). Solutions and tests of the diffusion equation for the movement of water in soil: Soil Sci. Soc. America Proc., v. 22, no. 3, p. 197-201, 1958.

Results of the theoretical analysis are compared with laboratory results.

2. Some steady-state solutions of the unsaturated moisture flow equation with application to evaporation from a water table: Soil Sci,, v. 85, no. 4, p. 228-232, 1958.

A transformation is given which makes possible the exact solution of some steadystate unsaturated-flow problems and approximate solution of some transient problems. Steady-state evaporation from a soil in which there is a water table is examined.

3. (and Fireman, Milton). Laboratory studies of evaporation from soil columns in the presence of a water table: Soil Sci., v. 85, no. 5, p. 244-249, 1958.

The experimental rates of evaporation of water from laboratory soil columns were compared with the theoretical solutions of the steady-state unsaturated moistureflow equation. Good agreement between theory and experiment was found.

GARNER, J. M., JR.

(and Kochtitzky, Oscar W.). Radioactive sediments in the Tennessee River system: Am. Soc. Civil Engineers Proc., v. 82, no. SA 4, Paper 1051, 20 p., 1956.

The equipment and techniques for determining the concentration of radioactivity in river sediments are described.

Garstka, Walter U. See also Allen, F. C.; Moran, W. T.; Timblin, L. O., Jr., 1. 
1. Reduction of canal losses and of evaporation losses from reservoirs: Natl. Water Resources Inst., Lincoln, Nebr., 1958, Proc., p. 130-154.

Report outlines measures for canal loss reduction with discussion of types of canal linings tested on Bureau of Reclamation projects, such as concrete, asphalt, chemical soil sealants, and plastic linings. It also outlines measures for reservoir evaporation loss reduction and discusses tests using hexadecanol monomolecular layer on the water surface.

2. (and Love, L. D., Goodell, B. C., and Bertle, F. A.). Factors affecting snowmelt and streamflow: U.S. Bur. Reclamation and U.S. Forest Service, 189 p., Illus., 1958.

Relationships between snowmelt and the climatic factors of air temperature, humidity, wind, and solar radiation were exhaustively investigated and equations were formulated. The best of these are used with characteristics of antecedent streamflow in a technique developed to forecast the shape of a day's snowmelt hydrograph. Comparisons are made with other techniques, and the relation of the areal snow coverage of a watershed to the streamflow hydrograph is examined.

Gatewood, J. S.

1. Index of surface-water records to September 30, 1955, part 7, lower Mississippi River basin: U.S. Geol. Survey Circ. 387, 20 p., 1956.

An index giving drainage area and period of record is presented.

2. Index of surface-water records to September 30, 1955, part 8, western Gulf of Mexico basins: U.S. Geol. Survey Circ. 388, 25 p., 1956.

An index giving drainage area and period of record is presented.

3. Index of surface-water records to September 30, 1955, part 9, Colorado River basin: U.S. Geol. Survey Circ. 389, 31 p., 1956.

An index giving drainage area and period of record is presented.

4. Index of surface-water records to September 30, 1955, part 10, The Great Basin: U.S. Geol. Survey Circ. 390, 22 p., 1956.

An index giving drainage area and period of record is presented.

5. Index of surface water records to September 30, 1955, part 11, Pacific slope basins in California: U.S. Geol. Survey Circ. 391, 27 p., 1956.

An index giving drainage area and period of record is presented.

GAUfin, A. R.

1. (and Tarzwell, C. M.). Environmental changes in a polluted stream during winter: Am. Midland Naturalist, v. 54, no. 1, p. 78-88, 1955.

2. The effects of pollution on a midwestern stream: Ohio Jour. Sci., v. 58, p. 197, 1958.

Gauthier, F. B.

Time exposures record water current movements: Indus. Photography, v. 7, no. 3, p. 20-21, 1958.

Studies of water current action in models at Waterways Experiment Station are described.

Gay, Henry R. See Douglass, J. B.

Gentry, Robert C.

1. Wind velocities during hurricanes: Am. Soc. Civil Engineers Trans., v. 120, p. $169-180,1955$.

The structure of hurricanes, duration and distribution of wind velocity, variation of wind velocity with height, and the probability of hurricane occurrence are examined. 
2. (and Simpson, R. H.). Hurricanes: Smithsonian Inst. Pub., no. 4277, 28 p., 1957.

The report compares characteristics, covers main causes of damage, discusses advances in knowledge during the past decade, and explains the different phases of hurricane forecasting.

Georgia School of Law.

A study of the riparian and prior appropriation doctrines of water law: Ga. Univ. Inst. Law and Govt. Pub., 95 p., 1955.

This paper describes the two basic doctrines of water law and the nature of the rights of water users in the jurisdiction following each of the doctrines.

Georgia Water Laws Revision Commission.

Water in Georgia: Ga. Water Use and Conserv. Comm. Rept., 85 p., 1955.

This is a nontechnical report on the historical, physical, and legal aspects of water in Georgia.

Geurin, J. W. See also Dover, T. B.

(and Jeffery, H. G.). Chemical quality of surface waters of Arkansas, 1945-55: Ark. Univ. Eng. Expt. Sta. Bull. 25, 79 p., 1957.

Geuther, Carl E.

Legal aspects of stream pollution: Sewage and Indus. Wastes, v. 30, no. 8, p. 1050-1056, 1958.

Nature of a riparian right, nature of the remedy, statutes, interstate compacts, and federal legislation are discussed.

Geyer, John C. See Bryant, G. T.; Fair, G. M.

Grbbons, R. D. See Berndt, H. W.

Grlcrest, Bruce R.

(and Schuleen, Emil P., and Landenberger, Edgar W.). Flood control plan for the Ohio River basin: Am. Soc. Civil Engineers Proc., v. 83, no. WW 1, Paper 1209, 16 p., 1957.

The plan developed by the Corps of Engineers is described.

Grues, Gordon C.

(and Colbert, Jesse L.). Observations on the Nisqually Glacier, Washington, and Grinnell, Jackson and Sperry Glaciers, Montana: Western Snow Conf. Proc., p. 3-6, Apr. 1955.

The observations made are described.

Gillilland, E. R.

Fresh water for the future: Indus. and Eng. Chemistry, v. 47, no. 12, p. 24102422, 1955.

Using storage, reducing total evaporation, and separating water and salt from sea water are possible ways of obtaining a greater dependable supply. Desalinization methods described are multieffect distillation, vapor distillation, solar distillation, freezing, extraction and adsorption, osmosis, and ion exchange and electrodialysis.

Gilman, Charles S.

(and Peterson, Kendall R.). Northeastern floods of 1955; Meteorology of the floods: Am. Soc. Civil Engineers Proc., v. 84, no. HY 3, Paper 1661, 37 p., 1958. This paper examines the physical reasons for the occurrence of the rainfall. (Discussion by H. Alden Foster, v. 84, no. HY 6, Paper 1856, p. 89-90, 1958.)

Glaser, A. H. See Lemon, E. R., 2. 
Gleason, Clark H.

1. (and Packer, Paul E., and Hockensmith, Roy D.). Watershed damage-its signs and courses: Am. Forests v. 61, no. 6, p. 34-37, 1955.

If people learn to recognize signs of watershed abuse, they can act to prevent serious damage to the land and water resources. The authors give examples of damaged watersheds in the United States, and they relate these conditions to the land uses that were responsible.

2. Reconnaissance methods of measuring erosion: Jour. Soil and Water Conserv., v. 12 , no. 3 , p. 105-107, 1957.

Reference points, established where none are naturally available, allow more accurate determinations of the amount of erosion.

3. Watershed management--an annotated bibliography of erosion, streamflow and water yield publications by the California Forest and Range Experiment Station: U.S. Forest Service Calif. Forest and Range Expt. Sta., Tech. Paper 23, 79 p., 1958.

Report lists and describes 204 staff publications on forest influences from establishment of the experiment station in 1926 to May 1957; cites several earlier publications that helped orient early research at the station.

Glock, WaLdo S.

Tree growth and rainfall: Am. Geophys. Union Trans., v. 36, p. 315-318, 1955.

The relationship of tree growth to rainfall is obtained by analysis of growth patterns and by correlation.

Glover, Robert E. See also Allen, F. C.; Zee, C. H.

A new method for predicting transient states of salinity intrusion into the Sacramento-San Joaquin Delta: Am. Geophys. Union Trans., v. 36, p. 641-648, 1955.

The mechanism by which the tidal changes propagate salinity into the delta channels and the manner in which this propagation is opposed by the fresh water stream flows are expressed in mathematical form. These methods are used to determine a depletion curve for the Delta.

Gloyna, E. F. See Hermann, E. R.

GLymph, Louis M., JR.

Importance of sheet erosion as a source of sediment: Am. Geophys. Union Trans., v. 38 , p. $903-907,1957$.

Estimating the sources of sediment comprising sediment yield from a watershed is necessary in planning protective measures. Sheet erosion is the dominant source in most of 113 watersheds studied.

GoLd, L. W.

(and Williams, G. P.). Some results of the snow survey of Canada: Eastern Snow

Conf. Proc., v. 4, p. 42-51, 1956.

Preliminary results from the survey begun in 1947 on the physical characteristics of snow cover are given.

Goldin, Abraham S. See Setter, L. R., 1, 2; Straub, C. P.

Golze, Alfred R. See Banks, H. O., 2; Thomas, R. O., 2.

Gooch, Robert S. See Harleman, D. R. F.

Goodell, Bertram C. See also Garstka, W. U., 2.

1. (and Wilm, H. G.). How to get more snow water from forest lands, in U.S. Department of Agriculture, Water: Yearbook of Agriculture 1955, p. 228-234. 
The relation of forests to snow accumulation and melting is described, and means of increasing snow-water supplies are suggested.

2. The snow research program at the Fraser Experimental Forest, Colorado:

Western Snow Conf. Proc., p. 35-38, Apr. 1956.

Principal research is on the relation of snow accumulation, and subsequent streamflow, to forest cover.

3. A preliminary report on the first year's effects of timber harvesting on water yield from a Colorado watershed: Rocky Mtn. Forest and Range Expt. Sta. Paper 36, 12 p., 1958.

Increases in streamflow have followed the removal of half of the mature timber from the watershed of a snow-fed stream. The spring flood peak was increased the first year after cutting and decreased in comparison with the control in the second year.

4. Watershed studies at Fraser, Colorado: Soc. Am. Foresters Proc., p. 42-45, 1958. Preliminary results indicate that strip cutting of timber significantly affected water yield from the winter snowfall. The basic conditions and the statistical analysis are described.

Goodrich, Ralph D. See also Langbein, W. B., 1.

Methods of determining consumptive use of water for irrigation: Am. Soc. Civil

Engineers Trans., v. 122, p. 806-817, 1957.

Standard methods of determining rates of consumptive use are described. (Discussion by Don M. Forester.)

Goodwin, A. B. See Speer, P. R., 1.

Gordon, E. D. See Dingman, R. J., 1.

GotaAs, H. B. See Krone, R. B.

Gotrtey, Sidney. See Jenkins, D. S., 1.

Gottschalk, L. C.

1. (and Jones, Victor H.). Valleys and hills, erosion and sedimentation, in U.S.

Department of Agriculture, Water: Yearbook of Agriculture 1955, p. 135-143.

Erosion, transportation, and deposition of sediment are described; examples of reductions in sediment yields due to watershed improvements are shown.

2. Problems of predicting sediment yields from watersheds: Am. Geophys. Union

Trans., v. 38, p. 885-888, 1957.

Three methods of predicting sediment yields are described.

Gould, B. W. See Langbein, W. B., 5.

Graham, Edward H.

(and Van Dersal, William R.). Water for America: New York, Oxford Univ. Press, 112 p., 1956.

The story of water conservation is presented in a popular style.

Graham, JACK B.

1. Technical aid in ground water problems: Water Works Eng., v. 108, no. 11, p. 1054, 1955.

The ground-water geologist can apply scientific methods to a ground-water problem.

2. (and Burrill, Meredith F.). Water for industry: Am. Assoc. Adv. Sci. Pub. 45, 141 p., 1956.

Report of a symposium presented on Dec. 29, 1953, at the Boston Meeting of the American Association for the Advancement of Science. The subject area is thoroughly covered. 
Granger, D. W. See Ash, A. S.

Graves, Eugene A.

Hydraulic requirements (in Old River diversion control-a symposium): Am.

Soc. Civil Engineers Trans., v. 123, p. 1142-1159, 1958.

Record floods and record minimum flows in Mississippi, Old, and Atchafalaya Rivers are given. Proposed hydraulic structures will assist in maintaining the regimen of the Mississippi River.

Gray, Harold E. See Bouwer, H.

Greeley, Samuel A. See Schnader, W. A.; Stein, M.

Greenhalgh, William H. See Warnick, F. M.

Greenman, David W. See also Barksdale, H. C., 2.

Ground-water resources of Bucks County, Pennsylvania: Pa. Topog. and Geol. Survey Bull., 66 p., 1955.

Gregory, G. Robinson.

Economic research needs in watershed management: Soc. Am. Foresters Proc., p. 35-39, 1957.

The problems are defined.

Grenier, A. RalPh.

Water spreading pays off. Soil Conserv., v. 21, no. 8. p. 173-175, 1956.

Report is on range improvement in Nebraska.

Griffin, W. C.

(and Watkins, F. A., Jr., and Swenson, H. A.). Water resources of the Portland, Oregon, and Vancouver, Washington, area: U.S. Geol. Survey Circ. 372, 45 p., 1956.

The water supply available exceeds requirements for any foreseeable industrial expansion.

Griffith, C. A.

Development of the California water plan: Am. Water Works Assoc. Jour., v. 47, no. 4, p. 367-373, 1955.

The plan provides for the full practicable development, control, and utilization of water resources. It is based on inventories of water resources and of present water utilization and estimated future needs.

GrofF, S. L.

A summary report on the ground-water situation in Montana, with a section on Montana and the law on groundwater, by Albert Stone: Mont. Bur. Mines and Geology Inf. Circ., no. 26, 45 p., 1958.

Groot, Johan J. See Rasmussen, W. C., 2, 4, 5.

Groot, John J. See Love, C. L.

Grossman, I. G. See Asselstine, E. S.

Guess, Clair P., Jr.

Water rights policies in the Southeast: Am. Water Works Assoc. Jour., v. 47, no. 9, p. 840-844, 1955.

A description of various types of rights and the need for some form of the appropriative system are given.

Gumbel, E. J. See Moran, P. A. P. 
Gustavson, R. G.

Water, the nation's concern today-a problem tomorrow: Jour. Soil and Water

Conserv., v. 12, no. 6, p. 259-264, 1957.

The place of water in the culture of peoples is discussed.

Guyton, William F.

Groundwater investigations: Water Well Jour., v. 10, no. 5, 1956.

The paper points out the need for more basic data on ground-water supplies and describes some of these data.

Grosdesky, Vasyl. See Eardley, A. J.

Haber, David.

(and Bergen, Stephen W.). The law of water allocation in the Eastern United States: New York, Ronald Press Co., 643 p., 1958.

This volume contains the papers of a 1956 symposium sponsored by The Conservation Foundation. The symposium was arranged to consider the problem of increasing conflicts of interest over water rights and the need for revising existing laws.

HACK, JoHN T.

Studies of longitudinal stream profiles in Virginia and Maryland: U.S. Geol. Survey Prof. Paper 294-B, p. 45-97, 1957.

Measurements of stream length, drainage area, channel slope, channel cross section, and size of material on the streambed were related. Several generalizations were made.

HACKeTt, James E.

(and Bergstrom, Robert E.). Groundwater in northwestern Illinois: Ill. Geol. Survey Circ. 207, 24 p., 1956.

Possibilities for development of ground-water supplies range from poor to excellent. The report discusses ground-water principles, summarizes the geologic factors that control the availability of ground water, and describes methods of developing ground-water supplies.

Haddock, J. L. See Taylor, S. A., 2.

Hadley, R. F. See also Schumm, S. A., 3.

(and Rolfe, B. N.). Development and significance of seepage steps in slope erosion:

Am. Geophys. Union Trans., v. 36, p. 792-804, 1955.

An hypothesis is offered for the development of one type of erosional scarplets on semiarid hillsides. These scarplets, usually less than 2 feet in height, are caused by seepage of subsurface flow between the surficial mantle and the weathered bedrock. (Discussion by Don U. Deere and Dipankar Niyogi; and authors' closure, v. 37, p. 636,1956 .)

\section{HADLEY, William A.}

(and Eisenstadt, Raymond). Thermally actuated moisture migration in granular media: Am. Geophys. Union Trans., v. 36, p. 615-623, 1955.

The movement of moisture in granular media with varying temperature gradients was studied in a laboratory by means of radioactive tracers. The mode of moisture movement is controlled by a critical moisture content found theoretically and experimentally to be about 4 percent.

Hagan, R. M. See Hall, W. A., 5.

HAGEe, G. R. See Straub, C. P. 
Hahn, Charles L.

Reservoir sedimentation in Ohio: Ohio Div. Water Bull. 24, 87 p., 1955.

The report describes the causes and effects of sedimentation, the general conditions affecting sedimentation in Ohio, and studies on 85 reservoirs of varying size.

HaHN, RICHARD B.

(and Straub, Conrad P.). Determination of radioactive strontium and barium in water: Am. Water Works Assoc. Jour., v. 47, no. 4, p. 335-340, 1955.

A procedure is given from which a precision of about 10 percent was obtained.

Haise, Howard $R$.

1. How to measure the moisture in the soil, in U.S. Department of Agriculture,

Water: Yearbook of Agriculture 1955, p. 362-371.

Six general methods are described.

2. (and Donnan, William W., Phelan, John T., Lawhon, Lester F., and Shockley, Dell G.). The use of cylinder infiltrometers to determine the intake characteristics of irrigated soils: U.S. Dept. Agriculture ARS 41-7, 10 p., May 1956.

Cylinder infiltrometers that have been found suitable for use in determining the intake characteristics of irrigated soils are described and illustrated. Standardized equipment and procedures are needed so that results can be correlated between different field personnel.

Hale, Malcolm D. See Daniels, W. S.

Hale, William E.

1. Geology and ground-water resources of Webster County, Iowa: Iowa Geol. Survey Water Supply Bull. 4, 257 p., 1955.

2. Ground-water conditions in the vicinity of Rattlesnake Springs, Eddy County,

New Mexico: N. Mex. State Engineer Tech. Rept., no. 3, 55 p., 1955.

The report discusses the relation of ground water to Rattlesnake Springs and the effects of pumping from wells in the area on the flow of these springs.

Hall, G. Robert. See Larson, F. H.

HaLl, WarRen A.

1. Theoretical aspects of water spreading: Agr. Eng., v. 36, no. 6, p. 394-397, 1955. This is a theoretical discussion of the effects of variation in permeability of soil with depth on the prolonged submergence infiltration rates. A method is proposed for evaluating a prospective location for water spreading.

2. An analytical derivation of the Darcy equation: Am. Geophys. Union Trans., v. 37, p. $185-188,1956$.

The equation is derived in general form for nonisotropic porous media from Newton's basic laws of motion and viscosity.

3. Permeability and infiltration relationships in one-dimensional infiltration in a uniform soil: Am. Geophys. Union Trans., v. 37, p. 602-604, 1956.

Equations are developed and compared with experimental results. (Discussion by J. R. Philip, v. 39, p. 123-124, 1958.)

4. Perched water tables under an artificial ground-water recharge system: Am. Geophys. Union Trans., v. 38, p. 346-348, 1957.

Hydrostatic pressure measurements show the nature of the growth of perched water tables resulting from the spreading operation.

5. (and Hagan, R. M., and Axtell, J. D.). Recharging ground water by irrigation:

Agr. Eng., v. 38, no. 2, p. 98-100, 1957.

An experiment is described in which ground-water recharge was accomplished by 
applying excess irrigation water to alfalfa at those times of the year when surplus water was available.

Halpenny, L. C. See Cushman, R. L.; Wolcott, H. N.

Halstead, Maurice H.

(and Covey, Winton). Some meteorological aspects of evapotranspiration: Soil

Sci. Soc. America Proc., v. 21, no. 5, p. 461-464, 1957.

Equations based on the concept of potential evapotranspiration or consumptive use commonly assume a homogeneous soil-moisture regime of infinite horizontal extent. This assumption does not hold in irrigated areas. It is shown that a solution can be obtained from a strictly physical point of view.

Hamburg, George R. See Milligan, C. H., 2.

Hamilton, E. L. See also Sinclair, J. D.

(and Reimann, L. F.). Simplified methods of sampling rainfall on the San Dimas Experimental Forest: U.S. Forest Service, Calif. Forest and Range Expt. Sta. Tech. Paper 26, 8 p., 1958.

By refining rainfall measurement techniques and sampling methods, a 21-gage network was made more useful than a former network of 300 gages.

Hamming, Edward.

Water legislation: Econ. Geography, v. 34, no. 1, p. 42-46, 1958.

This is a general discussion.

Hanes, Francis P.

Telemetering hydrologic data: Am. Soc. Civil Engineers Proc., v. 83, no. WW 3, Paper 1365, 17 p., 1957.

Equipment for rapid and unattended reporting of river levels and precipitation amounts is described.

HANKS, R. J.

(and Woodruff, N. P.) Influence of wind on water vapor transfer through soil, gravel, and straw mulches: Soil Sci., v. 86, no. 3, p. 160-164, 1958.

Experiments are described, and the results are given.

Hanna, Mikhail S. See Fathy, A.

HANnAFord, JACK F. See also Court, A., 2.

1. Multiple-graphical correlation for water-supply forecasting: Western Snow Conf. Proc., p. 26-32, Apr. 1956.

April through July runoff is graphically related to a snowpack index and four other indexes.

2. (and Wolfe, C. G., and Miller, R. W.). Graphical method for determination of area-elevation weighting of snow course data: Western Snow Conf. Proc., p. 73-82, Apr. 1958.

The method is described for Yuba River basin. Result is a snowpack index used in forecasting.

Hansen, O. C. See Benedict, P. C., 1.

Hansen, Vaughn E. See also Zee, C. H.

Infiltration and soil water movement during irrigation: Soil Sci., v. 79, no. 2, p. 93-105, 1955.

This paper deals with the movement of water through the soil from a source of atmospheric pressure. The three basic parts of the phenomena of water movement 
are transmission zone, wetting zone, and wetting front. Theoretical developments for horizontal, upward, and downward flow are given.

Hanson, E. L.

(and Christian, N. L.). Bureau of Reclamation quality of water program: Proc. Conf. Quality Water Irrig., Davis, Calif., 1958, Proc., Contr. 14, sec. 2, p. 19-25.

Hanson, Ross.

Groundwater resources in Lee and Whiteside Counties: Ill. Water Survey Rept. Inv. 26, 67 p., 1955.

Records of 529 wells which penetrate the sandstone, limestone, and glacial drift aquifers are tabulated. Daily pumpage is estimated.

Hantush, MaHdi S.

1. (and Jacob, C. E.). Non-steady radial flow in an infinite leaky aquifer: Am. Geophys. Union Trans., v. 36, p. 95-100, 1955.

The nonsteady-drawdown distribution near a well discharging from an infinite leaky aquifer is presented. Variation of drawdown with time and distance caused by a well of constant discharge in confined sand of uniform thickness and permeability is obtained. Two forms of the solution are developed.

2. (and Jacob, C. E.). Non-steady Green's functions for an infinite strip of leaky aquifer: Am. Geophys. Union Trans., v. 36, p. 101-112, 1955.

Solutions are obtained for the nonsteady flow to a well in an infinite strip of leaky aquifer whose boundaries are maintained either at a constant head or at a vanishing flux. These solutions are used to deduce the corresponding solutions for nonleaky aquifers. Also they are used to obtain the nonsteady Green's functions for the infinite strips. Green's functions are tabulated for infinite quadrants and half planes.

3. (and Jacob, C. E.). Steady three-dimensional flow to a well in a two-layered aquifer: Am. Geophys. Union Trans., v. 36, p. 286-292, 1955.

A solution is obtained for the potential distribution induced by a well screened in uniform sand and pumped at a constant rate. This sand is overlain by another sand of different permeability. A second solution is obtained for the case where the well is screened in the upper of the two sands. The validity of earlier assumptions made to reduce three-dimensional problems to two dimensions is verified.

4. Analysis of data from pumping tests in leaky aquifers: Am. Geophys. Union Trans., v. 37, p. 702-714, 1956.

Graphical methods are outlined for determining the coefficients of transmissibility, storage, and leakage of an effectively infinite leaky aquifer. The methods are applied to data from the Roswell artesian basin in New Mexico.

Happ, Stafford C. See Lane, E. W., 1.

Happel, John. See Irmay, S.

Harbeck, G. EARL, JR. See also Thomas, N. O.

1. The effect of salinity on evaporation: U.S. Geol. Survey Prof. Paper 272-A, p. 1-6, 1955.

For a given rate of evaporation from pure water, the effect of salinity on evaporation can be determined by using the theory presented.

2. Can evaporation losses be reduced?: Am. Soc. Civil Engineers Proc., v. 84, no. IR 1, Paper 1499, 8 p., 1958.

Methods of minimizing evaporation are presented. The use of a monomolecular film on the water surface and use of ground-water reservoirs for storage warrant additional study. (Discussion by Robert O. Thomas, v. 84, no. IR 2, Paper 1615, 
p. 31-33, 1958, and author's closure, v. 85 , no. IR 1, Paper 1986, p. 69, 1959.)

3. (and Kohler, Max A., and Koberg, Gordon E.). Water-loss investigations: Lake Mead studies: U.S. Geol. Survey Prof. Paper 298, 100 p., 1958.

A comprehensive study indicated that the evaporation loss from Lake Mead during the 1953 water year was 875,000 acre-feet. Techniques were developed for the continuing determination of monthly evaporation from the reservoir.

Harder, A. $\mathrm{H}$.

(and Drescher, W. J.). Ground-water conditions in southwestern Langlade County,

Wisconsin: U.S. Geol. Survey Water-Supply Paper 1294, 39 p., 1954 [1955].

Sand and gravel deposits are the principal aquifer. The source, discharge, and use of ground water and fluctuations of the water table were determined from records on more than 300 wells.

Harder, James. See Banks, H. O., 1.

Harder, James A. See Baumann, P.

HaRdin, John R.

The general problem (in Old River diversion control-a symposium): Am. Soc.

Civil Engineers Trans., v. 123, p. 1131-1141, 1958.

This paper describes the Old River-Atchafalaya River distributary of the Mississippi River and the need for control to maintain the present distribution of flood flows between the Mississippi and Atchafalaya Rivers.

Harding, S. T.

Statutory control of ground water in the Western United States: Am. Soc. Civil Engineers Trans., v. 120, p. 490-498, 1955.

This is a discussion of the problem.

Hardison, C. H. See Langbein, W. B., 1.

Hardman, Robert L.

Irrigation in New Jersey: Am. Soc. Civil Engineers Proc., v. 84, no. IR 2, Paper 1591, 9 p., 1958.

The recent rapid growth of irrigation, the available water, and experimental studies are described. (Discussion by Frederick L. Hotes, v. 84, no. IR 3, Paper 1784, p. $39,1958$.

Hargreaves, George H.

Irrigation requirements based on climatic data: Am. Soc. Civil Engineers Proc., v. 82, no. IR 3, Paper 1105, 10 p., 1956.

Physical laws, climatic data, and theoretical considerations are used in deriving equations for determining consumptive use for any set of climatic conditions. (Discussion by M. A. Selim, v. 83, no. IR 1, Paper 1257, p. 25-28, 1957, and author's closure, v. 84, no. IR 1, Paper 1521, p. 7-8, 1958.)

Harleman, Donald R. F.

(and Gooch, Robert S., and Ippen, Arthur T.). Submerged sluice control of stratified flow: Am. Soc. Civil Engineers Proc., v. 84, no. HY 2, Paper 1584, 15p., 1958.

Results are presented of experimental and analytical studies on the selective withdrawal of water from reservoirs or rivers in which density stratifications occur.

HARPER, V. L.

What's ahead for watershed management research on forest and range lands: Soc. Am. Foresters Proc., p. 116-118, 1956. 
The problems are (1) rehabilitation of degenerated watersheds, (2) increasing the usable yield of water, and (3) preventing watershed degeneration.

Harrington, E. R.

Sinkholes, bottomless lakes, and the Pecos River: Sci. Monthly, v. 84, no. 6, p. 302-308, 1957.

Geology and ground water of the Sacramento Plain, N. Mex., are discussed.

Harris, D. Lee. See also Conner, W. C.

1. Some problems involved in the study of storm surges: U.S. Weather Bur., Natl. Hurricane Proj. Rept. No. 4, 30 p., 1956.

This report presents some case studies of the storm surge--the effect of a storm on the sea level.

2. The effect of a moving pressure disturbance on the water level in a lake (in Interaction of Sea and Atmosphere, a Group of Contributions, by A. C. Redfield, A. R. Miller, and others): Am. Meteorol. Mon., v. 2, no. 10, 1957. 3. (and Lindsay, C. V.). An index of tide gages and tide gage records for the Atlantic and Gulf coasts of the United States: U.S. Weather Bur., Natl. Hurricane Proj. Rept. No. 7, 104 p., 1957.

Tables show station location, type of gage, upper and lower limits, period of record and agency. Gage locations are also shown on maps.

4. Meteorological aspects of storm surge generation: Am. Soc. Civil Engineers Proc., v. 84, no. HY 7, Paper 1859, 25 p., 1958.

A model suitable for use in hurricane storm tide studies and an empirical relation between hurricane intensity and tide height are given. (Discussion by J. R. Bowman, v. 85, no. HY 6, Paper 2076, p. 73-74, 1959; and author's closure, v. 85, no. HY 10, Paper 2235, p. 141, 1959.)

5. Hurricane Audrey storm tide: U.S. Weather Bur., Natl. Hurricane Proj. Rept. No. 23, 19 p., 1958.

Study of the storm-tide data available leads to the conclusion that warning procedures could be more effective if information on the current state of the tide heights on the open coast were available at proper places inland.

Harris, Hobart B.

Springs in Colbert and Lauderdale Counties, Alabama: Ala. Geol. Survey Inf. Ser., 16 p., 1957.

Harris, K. F. See McAvoy, R. L.

Harrold, Lloyd L. See also King, K. M.

1. Evapotranspiration rates for various crops: Agr. Eng., v. 36, no. 10, p. 669-672, 1955.

Evapotranspiration rates for different crops vary notably throughout the growing season. These rates are presented for various crops as an aid to irrigation design, research, and operation.

2. A study of rain storms: Soil Conserv., v. 21, no. 4, p. 90-94, 1955.

Precipitation characteristics and their relation to floods are described.

3. Upstream surface-water supplies-need for facts: Jour. Soil and Water Conserv., v. 11, no. 4, p. 174-176, 1956.

Runoff characteristics of small watersheds are given, and the need for information on many streams is emphasized.

4. Minimum water yield from small agricultural watersheds: Am. Geophys. Union Trans., v. 38, p. 201-208, 1957. 
This paper presents methods of analyzing and reporting data on minimum runoff from watersheds of 29 to 17,540 acres in Ohio.

5. Effect of vegetation on soil moisture: Am. Soc. Agr. Engineers Trans., v. 1, no. 1, p. 6-8, 11, 1958.

6. Lysimeter checks on empirical evapotranspiration values: Agr. Eng., v. 39, no. 2, p. 94-97, 1958.

Estimates obtained from some empirical methods were compared with lysimeter measurements. The comparison was encouraging but improvement is needed. 7. (and Dreibelbis, F. R.). Evaluation of agricultural hydrology by monolith lysimeters 1944-55: Ohio Agr. Expt. Sta. Tech. Bull., no. 1179, 146 p., 1958.

A progress report on the lysimeter investigations carried on at the Soil and Water Conservation Research Station near Coshocton, Ohio, from 1944 through 1955. Summaries of percolation data are presented for the period 1938-55.

Harshbarger, John W.

Use of ground water in Arizona: Ariz. Univ. Bull., v. 28, no. 4, p. 51-68, 1957.

A brief resume of ground-water conditions in Arizona is given.

Hart, Henry C. See also Duke University School of Law.

The dark Missouri: Madison, Wis., Wis. Univ. Press, 260 p., 1957.

This book deals with the problems of rainfall, lack of rainfall, floods, dams, power, wind erosion, of reclaimed land and of lost land. Government programs are treated, and a new approach to governing water supplies is recommended.

Hartman, M. A.

1. (and Wilke, Richard W.). Downstream effects of upstream floodwater-retarding structures: Jour. Soil and Water Conserv., v. 10, no. 5, p. 219-222, 1955.

A summary of a study made by the U.S. Department of Agriculture is given. The computed reductions due to structures in the peaks of four representative Kansas floods are shown.

2. (and Wilke, Richard W.). Downstream effects of land treatment and upstream floodwater-retarding structures: U.S. Dept. Agriculture, SCS-TP-130, June 1956.

This study originated in 1954 to coordinate upstream watershed treatment with downstream projects. Estimated discharges of four representative floods under four present and future watershed conditions are given.

Hartung, Herbert O. See also Hatcher, M. P.

(and Palange, Ralph C., Megregian, Stephen, Cleary, Edward J., and Streicher,

Lee). Monitoring of stream water quality: Am. Water Works Assoc. Jour., v. 50, no. 9, p. 1211-1226, 1958.

A panel discussion giving the objectives, the U.S. Public Health Service program, and the procedures used on the Ohio River and Colorado River Aqueduct systems.

Harvey, Edward J.

1. Geology and ground-water resources of the Henderson area, Kentucky: U.S. Geol. Survey Water-Supply Paper 1356, 227 p., 1956.

The geography, geology, and the water-bearing formations of the area are described. Ground-water sources, movement, and discharge are deduced from records of many wells. These records are included.

2. (and Lang, J. W.). Ground-water resources of the Jackson area, Mississippiprogress report of current studies: Miss. Board Water Commissioners, 34 p., 1958.

Hassig, Elmer. See Berry, W. H. 
Hatcher, Melvin P.

(and Neel, Joe K., Erdei, Joseph F., and Hartung, Herbert O.). Effects of Missouri River basin control on water quality: Am. Water Works Assoc. Jour., v. 50, no. 9, p. 1185-1200, 1958.

A panel discussion covering conditions on the central Missouri River and at Omaha and St. Louis.

Hatchett, J. L. See Coates, D. R., 1, Krieger, R. A.

Hathaway, Gail A.

Basin-wide, multiple-purpose planning of our water resources: Civil Eng., v. 26, p. 45-47, Sept. 1956.

The advantages and requirements are discussed.

Haws, Frank W. See Lauritzen, C. W.

Hays, Orville E.

1. Factors influencing runoff: Agr. Eng., v. 36, no. 11, p. 732-735, 1955.

Effects are given of cover, temperature, time of year, and other variables on the runoff from two small cultivated watersheds and one small forested watershed.

2. (and Attoe, Osborne J.). Control of runoff and erosion on Almena silt loam in

Wisconsin: U.S. Dept. Agriculture, ARS 41-16, 19 p., 1957.

Eight years of runoff, soil loss, and yield data are presented to show the influence of row direction, stripcropping, and terracing on a gently sloping, poorly drained soil. Results indicate that contour stripcropping and terracing will reduce erosion without reducing crop yields.

Hazen, Richard.

1. Hudson River water-its characteristics and treatment: Am. Soc. Civil Engineers Proc., v. 81, Separate 644, 28 p., 1955.

This paper includes a description of the geographical and hydrological features of the Hudson River basin and summaries of stream surveys and quality data.

2. Rainfall and runoff in Eastern United States: Water Works Eng., v. 108, no. 3, p. 231-232, 1955.

A method of determining the storage required to produce a yield from a small basin is described.

3. Economics of streamflow regulation: Am. Water Works Assoc. Jour., v. 48, no. 7, p. 761-767, 1956.

Any national approach to streamflow regulation must begin with a study of the hydrology of the stream and consideration of the purpose of providing storage. Reservoirs cannot be built economically by small organizations so construction by water districts seems likely.

Heard, William L. See also Matson, H. O.

(and MacNaughton, Victor B.). The Yazoo-Little Tallahatchie flood prevention project, in U.S. Department of Agriculture, Water: Yearbook of Agriculture 1955, p. 199-205.

The account of a program in which Federal, State, and local agencies cooperated with private landowners to alleviate flooding and to improve the land.

Heath, W. A.

Cetyl alcohol for evaporation control: Water and Sewage Works, v. 105, no. 9, p. 361-362, 1958.

Costs and effectiveness of treatment on a small reservoir in Australia are given. Specifications for an acceptable form of cetyl alcohol are listed. 
Heidel, S. G.

The progressive lag of sediment concentration with flood waves: Am. Geophys. Union Trans., v. 37, p. 56-66, 1956.

An increase in streamflow usually is accompanied by an increase in sediment concentration. The sediment-concentration peak during a rise may precede, coincide with, or follow the water-discharge peak. Observations on Bighorn River show a progressive lag in peak concentration behind peak flow.

Heilman, John M.

Municipal watershed management in practice: Soc. Am. Foresters Proc., p. 32-34, 1957.

Experiences on the Pequannock watershed on which forestry management began in 1900.

Helwick, Charles $\mathrm{H}$.

(and Schosser, Frank A.). Artesian water-from a source five times greater than the Great Lakes: Water Works Eng., v. 110, no. 3, p. 236-239, 1957.

This paper describes the ground-water sources and the water system of Jacksonville, Fla.

Hembree, C. H. See Colby, B. R., 1, 2; Schroeder, K. B.

Henderson, Angus D. See Hill, R. A.

Hendricks, E. L. See Jones, P. H.

Hendrickson, A. H. See Veihmeyer, F. J., 1, 2.

Henley, A. T. See Kuder, W. B.

Henley, Laurel M. See French, R. R.

Henry, Harold R. See Tracy, H. J., 1.

HermanN, E. R.

(and Gloyna, E. F.). Waste stabilization ponds. I. Experimental investigations: Sewage and Indus. Wastes, v. 30, no. 4, p. 511-538, 1958.

Results of 4 years of experimental investigations employing laboratory models and outdoor pilot plants are reported.

Hermsmeier, L. F. See Larson, C. L.

Herndon, Louis W.

Drainage in the Mississippi River valley: Am. Soc. Civil Engineers Proc., v. 83, no. IR 2, Paper 1363, 11 p., 1957.

The relation of flood control and drainage is discussed. (Discussion by Clyde $\mathrm{P}$ Cass, Jr. and Richard T. Shen; and author's closure, v. 84, no. IR 3, Paper 1784, p. 11-16, 1958.)

Herrick, S. M. See Thomson, M. T., 2.

Hershfield, David M. See also Corn, H. M.; Linsley, R. K., 2; Potter, W. D., 2; Rowe, R. R.; Wilson, W. T., 2.

(and Weiss, Leonard L., and Wilson, Walter T.). Synthesis of rainfall intensityfrequency regimes: Am. Soc. Civil Engineers Proc., v. 81, Paper 744, 6 p., 1955. Short-duration rainfall intensities can be estimated from usually-available climatic data by the method presented. (Discussion by W. H. Sammons, v. 82, no. HY 1, Paper 881, p. 31-35, 1956; and author's closure, v. 82, no. HY 4, Paper 1041, p. 3-5 1956.)

Hert, Oral H. See Johnson, W. M. 
Hess, H. H.

(and Thurston, W. R.). Disposal of radioactive waste on land: Am. Geophys. Union Trans., v. 39, p. 467-468, 1958.

Conclusions of the National Research Council on Waste Disposal are presented.

Hess, W. B. See Swengel, R. C.

Hettick, Irene. See Larson, T. E., 1.

Heusser, Calvin J.

Variations of Blue, Hoh, and White glaciers during recent centuries: Arctic, v. 10, no. 3, p. 139-150, 1957.

A discussion is given of the activity of glaciers in the Olympic Mountains of western Washington.

Hewlett, John D.

Pine and hardwood forest water yield: Jour. Soil and Water Conserv., v. 13, no. 3, p. 106-109, 1958.

An experiment is described to detect whether there will be differences in the quantity of water flowing from a hardwood forest when converted to pine.

Hiatt, William E.

(and Schloemer, Robert W.). How we measure the variations in precipitation, in U.S. Department of Agriculture, Water: Yearbook of Agriculture 1955, p. 78-84. Methods of measuring precipitation and methods of interpreting the data for use in water resources development are described.

Highway Research BoARd.

Culvert-flow characteristics: Water Resources Council Highway Research Board Bull., no. 126, 23 p., 1956.

Report contains two papers, "Demonstration of Possible Flow Conditions in a Culvert" and "Tests on Circular-pipe-culvert Inlets."

Hildebrand, Carver E.

Lysimeter studies of snowmelt: Western Snow Conf. Proc., p. 94-105, Apr. 1957.

Processes of heat transfer are evaluated and melt coefficients derived. These coefficients were verified by comparing actual snowmelt with that computed by using the coefficients.

Hill, Raymond A. See also Robinson, A. R., Jr., 2.

(and Henderson, Angus D., Toth, A. S., and Clark, Edward J.). Controlled draft from reservoirs: Am. Water Works Assoc. Jour., v. 48, p. 341-354, 1956.

A panel discussion covering surface and underground storage, the limitary curve, and impounding reservoirs.

Hilton, George S. See Barksdale, H. C., 2.

Hinkle, D. A. See Bartholomew, R. P.

Hiser, Homer W. See also Huff, F. A., 2; Larson, B. O.; Stout, G. E.

1. Type distributions of precipitation at selected stations in Illinois: Am. Geophys. Union Trans., v. 37, p. 421-424, 1956.

Precipitation during a 10 -year period at four stations is classified according to its source from one of six major types of precipitation systems. The amount and frequency of occurrence for each type are given.

2. (and Senn, H. V., and Conover, L. F.). Rainfall measurement by radar using photographic integration techniques: Am. Geophys. Union Trans., v. 39, p. 1043-1047, 1958. 
Methods are described for estimating areal rainfall amounts as portrayed by radar. Also developed are echo-density contour maps which correlate with isohyetal maps.

3. Radar analysis of two severe storms in south Florida: Am. Meteorol. Soc. Bull., v. 39 , no. 7 , p. $353-359,1958$.

Radar photographs of two distinctly different severe storms are analyzed. Characteristics are given of the two radars used. Significant features of the storms as shown by radar are compared with findings of other researchers in different parts of the United States.

4. (and Ray, P. R., and Conover, L. F.). Investigation of rainfall measurement by radar; final report on contract CWB 9283: Miami Univ. Marine Lab., June 1958.

Hoak, Richard D.

1. Use and conservation of water resources in Eastern States: Am. Water Works Assoc. Jour., v. 47, no. 9, p. 858-864, 1955.

Future demands for water require the use of conservation measures.

2. (and Bramer, Henry C.). Natural sediment as a factor in stream pollution control: Sewage and Indus. Wastes, v. 28, no. 3, p. 311-322, 1956.

Three methods are presented for estimating the load of suspended solids in streams.

Новва, Roвert L. See Flaxman, E. M.

Hobson, T. J. See Jaeger, C.

Hockensmith, Roy D. See Gleason, C. H., 1.

Hodges, Paul V. See Tracy, H. J., 1.

Hodson, Warren G. See Stramel, G. J., 3.

Hoffman, J. F.

(and Spiegel, S. J.). Chloride concentration and temperature of water from wells in Suffolk County, Long Island, New York, 1928-53: N.Y. Water Power and Control Comm. Bull. 38, 55 p., 1958.

Hofmann, Walter.

(and Peterson, William C.). Water resources summary for southern California, 1956: U.S. Geol. Survey Circ. 399, 18 p., 1957.

This is one of a series of annual reports.

Holbrook, Stewart.

The Columbia: New York, Rinehart and Co., 393 p., 1956.

A popular account of history along the Columbia River is given.

Holland, W. D. See Wilcox, J. C.

HolLINGSWORTH, B. J.

(and Meyer, H. I.). Two-dimensional gravity drainage profiles: Am. Geophys. Union Trans., v. 39, p. 689-696, 1958.

This paper describes some studies on the shape of the fluid-fluid interface of a liquid which is draining by gravity from a saturated porous medium.

Hollis, M. D.

(and McCallum, G. E.). Federal water pollution control legislation: Sewage and Indus. Wastes, v. 28, no. 3, p. 306-310, 1956.

The main points of the legislation under consideration (1956) are briefly touched upon. 
Holmes, Henry B., Jr.

National and local aspects of water resources problems: Am. Water Works Assoc. Jour., v. 49, no. 6, p. 712-720, 1957.

This is a review of Federal, State, and local viewpoints with emphasis on Virginia.

Holmes, R. M. See Robertson, G. W.

Holmsgaard, Erik. See Wiksten, A.

Holsinger, Henry. See also Kuder, W. B.; Morris, S. B., 1.

Some legal aspects of ground water and the California water plan: Am. Water Works Assoc. Jour., v. 47, no. 4, p. 374-382, 1955.

Maintenance of utility of ground-water basins is essential to the plan.

Holtan, H. N. See also Ford, E. C.

1. Flood program-how effective?: Soil Conserv., v. 21, no. 4, p. 75-82, 1955.

Reports results obtained on Sandstone Creek watershed, Oklahoma.

2. Actual and estimated flooding on a protected watershed; Sandstone Creek, Okla.: U.S. Dept. Agriculture SCS-TP-129, 18 p., May 1956.

This report presents analyses of some of the first records of flows with a flood-reduction program in actual operation during two major storms.

Hom-ma, Masashi. See Delleur, J. W.

Hoover, Marvin D. See also Trousdell, K. B.; Price, R., 1.

Water yield research by the Rocky Mountain Forest and Range Experiment Station: Pacific Southwest Inter-Agency Comm. Minutes 56-4 (B), p. 14-20, Nov. 1956.

Report reviews results of past research and describes tests in progress.

Hoover, Robert A.

Empirical relationships of the central pressures in hurricanes to the maximum surge and storm tide: Monthly Weather Rev., v. 85, no. 5, p. 167-174, 1957.

An empirical relation arrived at by a different technique is effectively the same as the one presented by Conner and others. (See Conner, W. C.)

Hope, Clifford R.

Expanded opportunities for watershed development: Jour. Soil and Water Conserv., v. 11, no. 6, p. 271-277, 1956.

This paper discusses the need for a watershed program, legislation to support watershed development, and some dangers the program faces.

Hopkins, Charles D., Jr. See also Nash, J. E., 1.

Operation of the river forecast program in the United States: Eastern Snow Conf. Proc., v. 4, p. 35-38, 1956.

The program of U.S. Weather Bureau is described with emphasis on New England.

\section{Hopkins, David M.}

(and Karlstrom, Thor N. V.). Permafrost and ground water in Alaska: U.S. Geol. Survey Prof. Paper 264-F, p. 113-146, 1955.

The report includes a study of the interrelations of permafrost and ground water and a discussion of the role of aerial photographs in the mapping and evaluation of permafrost conditions.

Hopkins, Glen J.

(and Neel, Joe K.). Water quality in the Missouri River: Am. Soc. Civil Engineers Proc., v. 84, no. SA 1, Paper 1542, 10 p., 1958. 
Turbidity, hardness, alkilinity, and algae are examined from the standpoint of reservoir and pollutional influences. A bibliography is included.

\section{Hopkins, WALT.}

1. Cooperative financing of water management projects in California: Ariz. Watershed Program, 2d Ann. Mtg., Proc., p. 63-66, 1958.

The report reviews cooperative flood control and water supply projects in California and describes several lines of research being done with federal-state-local cooperation to protect watersheds and improve water yield.

2. More good water-research at San Dimas Experimental Forest applying fundamentals to entire watersheds: U.S. Forest Service, Calif. Forest and Range Expt. Sta. Misc. Paper No. 22, 6 p., 1958.

Progress and reorientation of San Dimas research program are discussed.

3. (and Sinclair, J. D., and Rowe, P. B.). From forest influences to applied watershed management in Southern California: Soc. Am. Foresters Proc., p. 36-38, 1958.

Research since 1933 provided the basic knowledge necessary to manage whole watersheds.

Hore, F. R. See Witherspoon, D. F., 1.

Honton, J. S. See also Carlson, C. A.

Use of electrical soil-moisture units in mountain soils: Western Snow Conf. Proc., p. 20-26, Apr. 1955.

Laboratory and field calibration of fiberglass units are described.

Hosler, C. L.

(and Gamage, L. A.). Cyclone frequencies in the United States for the period 1905

to 1954: Monthly Weather Rev., v. 84, no. 11, p. 388-390, 1956.

Monthly maps showing the average number of cyclones passing through each $5^{\circ}$ latitude-longitude grid.

Hotes, Frederick L. See Baumann, P.; Derby, R. L.; Hardman, R. L.

Houghton, Henry G.

Present position and future possibilities of weather control: Am. Meteorol. Soc. Bull., v. 38, no. 10, p. 567-570, 1957.

A general description of the present status and of the need for basic research is given.

Houk, Ivan E.

Irrigation Engineering, Vol. II: New York, John Wiley and Sons, 531 p., 1956.

This second volume includes chapters on dams and their appurtenant works, and on canals, conduits, and structures needed in distribution systems. It discusses irrigable lands, settlement of irrigation projects, maintenance of canals, and other general problems of irrigation agriculture.

Houston, Clyde E.

Consumptive use of water by alfalfa in western Nevada: Nev. Agr. Expt. Sta. Bull. 191, 20 p., 1955.

Howe, Everett D.

Progress in conversion of saline water: Am. Water Works Assoc. Jour., v. 50, no. 3, p. 319-330, 1958.

The research program of the University of California is described. Methods include using heat from nonfuel sources, reversed osmosis, application of ion exchange, distillation by pressure alone, and a thermodynamic analysis of each of the others. 
Howe, J. W. See Johnson, H. P.

Howe, Robert H. L.

1. (and Wilke, Harvey R., and Bloodgood, Don E.). Application of air photo interpretation in the location of ground water: Am. Water Works Assoc. Jour., v. 48, no. 11, p. 1380-1390, 1956.

Airphotos help in locating water-bearing sands and gravels in buried valleys, terraces, and other alluvial deposits.

2. Procedures of applying air photo interpretation in the location of ground water: Photogramm. Eng. v. 24, no. 1, p. 35-49, 1958.

Report describes a procedure which has been used and tested in the location of ground-water bearing foundations.

Howland, Wallace. See Morris, S. B., 1.

Hoyt, William G.

(and Langbein, Walter B.). Floods: Princeton, N.J., Princeton Univ. Press, 469 p., 1955.

The authors analyze the ways in which floods start, the damage they inflict, and what man can do to adapt to them, prevent them, and protect himself against them. They outline the judicial and legislative framework involved and suggest certain important changes. They describe the problems, projects and plans in every major basin in the United States and present a history of floods since 1543.

Hsien, J. C. See Gardner, W. H.

Huberty, Martin R. See also Taylor, E. H.; Swartzendruber, D., 3.

Water resources of the West, today and tomorrow: Calif. Acad. Sci. Proc., v. 28, no. 10 , p. 405-414, 1956.

The region considered includes 17 Western States and 7 major drainage basins.

Hubley, Richard C.

An analysis of surface energy during the ablation season on Lemon Creek Glacier, Alaska: Am. Geophys. Union Trans., v. 38, p. 68-85, 1957.

This is an empirical investigation of the energy transfer at an isothermal, melting snow surface and its relationship to meteorological parameters. Turbulent transfer of heat is found to be the most important factor in causing ablation on Lemon Creek Glacier.

Hudson, H. E., JR. See also Bruin, J., 1.

(and Roberts, W. J.). 1952-1955 Illinois drought, with special reference to impounding reservoir design: Ill. Water Survey Bull. 43, 52 p., 1955.

The report includes sources of supply, municipal water-supply difficulties, extent and intensity of the drought, and methods of estimating reservoir storage requirements.

Hudson, James W. See White, G. F., 2.

Huff, F. A. See also Changnon, S. A., Jr., 1.

1. Comparison between standard and small orifice rain gages: Am. Geophys. Union Trans., v. 36, p. 689-694, 1955.

Results from the small orifice gages compared closely with results from standard gages.

2. (and Hiser, H. W., and Stout, G. E.). The October 1954 storm in northern Illinois: Ill. Water Survey Rept. Inv. 27, 23 p., 1955.

A description of the unusually heavy rainstorm is given. Radar was found inadequate to accurately portray the depth and intensity of a storm. 
3. Standard versus small-orifice rain gages: Agr. Eng., v. 37, no. 2, p. 108, 1956. Three types of small gages were tested and found to be satisfactory for use in place of the standard 8-inch gage for measuring rainfall under most circumstances.

4. (and Neill, J. C.). Frequency of point and areal mean rainfall rates: Am. Geophys. Union Trans., v. 37, p. 679-681, 1956.

One-minute rainfall amounts from 19 storms at 50 sites were analyzed. (Discussion by Herbert M. Corn, and authors' closure, v. 38, p. 960-962, 1957.)

5. (and Neill, J. C., and Spock, M., Jr.). Evaluation of a low-powered 3-cm radar for quantitative rainfall measurements: Ill. Water Survey Rept. Inv.29,35 p., 1956.

An empirical relation between 1-minute areal mean rainfall and 1-minute radar data was used to obtain areal-mean rainfall depths for 28 storm periods. Results were compared with measured rainfall. Surface-rainfall data were compared with radar observations for 10 stations during 15 storms during 1953, and the results were evaluated.

6. (and Neill, J. C.). Areal representativeness of point rainfall: Am. Geophys. Union Trans., v. 38, p. 341-345, 1957.

Shower-type rainfall data in Illinois are the basis for empirical relations for average and standard errors of areal estimates for storm, weekly and monthly periods.

7. (and Neill, J. C.). Rainfall relations on small areas in Illinois: Ill. Water Survey Bull. 44, 61 p., 1957.

Data were obtained from several concentrated rain-gage networks. The many analyses include definition of variability, distribution, area-depth relations, and others. Studies are concentrated on relations during the spring to fall thunderstorm season.

8. (and Semonin, R. G., Changnon, S. A., Jr., and Jones, D. M. A.). Hydrometeorological analysis of severe rainstorms in Illinois, 1956-57, with summary of previous storms: Ill. Water Survey Div. Rept. Inv. 35, 79 p., 1958.

Detailed analyses of five storms and a summary of severe rainstorm analyses, 1948-57, are given.

Huffman, Roy E. See also Duke University School of Law.

Sharing the financial responsibility, in U.S. Department of Agriculture, Water:

Yearbook of Agriculture 1955, p. 677-681.

Activities of local groups have been responsible for most of the development of water resources.

HuFFT, JoHN C.

Laboratory study of wind waves in shallow water: Am. Soc. Civil Engineers Proc., v. 84, no. WW 4, Paper 1765, 20 p., 1958.

Results of the study are given, and relationships developed between velocity, fetch, and wave parameters for two different depths.

Hughes, Ronald D. See West, E. M.

Hull, Blanche B.

Hail size and distribution: U.S. OQG Environmental Protection Tech. Rept., no. 83, 89 p., 1957.

Basic information is provided on frequency of occurrence and geographical distribution of hail throughout the world. Principal theories of hail growth and factors which limit the maximum size of hailstones are discussed.

Hull, C. H. J. See Riddick, T. M.

Hulme, Arthur E. See Overbeck, R. M.; Rasmussen, W. C., 1, 3. 
Humpherys, Allan S. See Lauritzen, C. W.

Hurst, Harold Edwin. See Fathy, A.

Hutchins, Wells A. See also Kuder, W. B.

1. The Nevada law of water rights: Nev. State Engineer, 66 p., 1955.

This report represents a part of the revision by Hutchins of U.S. Dept. Agriculture Misc. Pub. 418, "Selected Problems in the Law of Water Rights in the West," by W. A. Hutchins, 1942, which covered 17 Western States.

2. The New Mexico law of water rights: N. Mex. State Engineer Tech. Rept., no. 4, 61 p., 1955.

This report was prepared as part of the revision of U.S. Dept. Agriculture Misc. Pub. 418, "Selected Problems in the Law of Water Rights in the West," by W. A. Hutchins, 1942, which covered 17 Western States.

3. The Oklahoma law of water rights: Okla. Div. Water Resources, 81 p., 1955.

This report was prepared as a part of the revision of U.S. Dept. of Agriculture Misc. Pub. 418, "Selected Problems in the Law of Water Rights in the West," by W. A. Hutchins, 1942, which covered 17 Western States.

4. Irrigation water rights in California: Calif. Agr. Expt. Sta. Circ. 452, 54 p., 1956.

The report was prepared as part of the revision of "Selected Problems in the Law of Water Rights in the West" which was issued in 1942 as Misc. Pub. 418 of the U.S. Department of Agriculture.

5. The Idaho law of water rights: Idaho Dept. Reclamation, 117 p., 1956.

The report was prepared as part of the revision of "Selected Problems in the Law of Water Rights in the West" which was issued in 1942 as Misc. Pub. 418 of the U.S. Department of Agriculture.

6. (and Smrha, R. V., and Smith, R. L.). The Kansas law of water rights: Kans. Div. Water Resources, 1957.

The report was prepared as part of a revision of "Selected Problems in the Law of Water Rights in the West" which was issued in 1942 by the U.S. Department of Agriculture.

Hutchinson, G. Evelyn.

A treatise on limnology. Vol. I. Geography, physics, and chemistry: New York, John Wiley and Sons, 1015 p., 1957.

The report gives as complete an account as possible of the events characteristically occurring in lakes.

Ilcewicz, Frank H. See Lucas, H. F., Jr.

Ilch, David M. See Matson, H. O.

Illinois State Water Survey Division.

Potential water resources of southern Illinois: Ill. Water Survey Rept. Inv. 31, 97 p., 1957.

A semitechnical publication which combines and analyzes available information on the water resources for the 17 southernmost counties.

Ince, Simon. See Rouse, H.

Indiana Division of Water Resources.

Water level records of Indiana: Ind. Div. Water Resources Bull. 7, 113 p., 1956.

Indiana Water Resources Study Committee.

Indiana water resources: Ind. Water Resources Study Comm., 42 p., 1956. 
This report offers the most completely coordinated survey of water resources thus far accomplished in Indiana. Supporting data are given in a technical appendix of the same name.

Ingebo, Paul A.

An instrument for measurement of the density of plant cover over snow course points: Western Snow Conf. Proc., p. 26-28, Apr. 1955.

Forest cover in a $45^{\circ}$ cone above a point is measured by a ceptometer. (Discussion by Paul E. Lemmon.)

Ingersoli, Alfred C. See Delleur, J. W.

Ingerson, Irvin M. See also Blaney, H. F., 5.

Lunar-cycle measurement of estuarine flows: Am. Soc. Civil Engineers Proc., v. 81, Paper 836, 18 p., 1955.

A method of making complete current-water measurements of oscillating tidal flows and methods of computing instantaneous values of measured fresh-water outflows are given. (Discussions by Franklin C. Craig, L. J. Tison, v. 82, no. HY 2, Paper 955, p. 41-50, 1956; John A. Roberson, v. 82, no. HY 3, Paper 1010, p. 11-12, 1956.)

INGOLS, ROBERT S.

Pollutional effects of hydraulic power generation: Sewage and Indus. Wastes, v. 29, no. 3, p. 292-297, 1957.

The storage of water for hydraulic power generation has some good features, but released water may be devoid of dissolved oxygen and may contain manganese and (or) sulfide.

Ingram, Willitam Marcus. See Ludzack, F. J., 2.

Inter-Agency Commrttee on Land Subsidence.

Progress report on land-subsidence investigations in the San Joaquin Valley, California through 1957: Inter-Agency Comm. Land Subsidence in San Joaquin Valley, Sacramento, 160 p., 1958.

Summarizes progress of investigation of subsidence of land surface of several feet in the Los Banos-Kettleman City, Tulare-Wasco, and Arvin-Maricopa areas as well as subsidence in lesser amount in other locations in California. Report discusses two chief types of subsidence giving causes of each.

Iowa Geological Survey.

Quality of surface waters of Iowa, 1886-1954: Iowa Geol. Survey Bull. 5, 351 p., 1955.

Iowa Natural Resources Council.

1. An inventory of water resources and water problems, Nishnabotna River basin, Iowa: Iowa Nat. Resources Council Bull., no. 2, 61 p., 1955.

Basin characteristics, water supply, water use, flood and sediment problems, and the development of a comprehensive water plan are discussed.

2. An inventory of water resources and water problems, Cedar River basin, Iowa: Iowa Nat. Resources Council Bull., no. 3, 93 p., 1955.

Basin characteristics, water supply, water use, floods, and development of a comprehensive water plan are discussed.

3. An inventory of water resources and water problems, Floyd-Big Sioux River basins, Iowa: Iowa Nat. Resources Council Bull., no. 4, 55 p., 1956.

Basin characteristics, water supply, water use, floods, and development of a comprehensive water plan are discussed.

4. An inventory of water resources and water problems, Skunk River basin, Iowa: Iowa Nat. Resources Council Bull., no. 5, 64 p., 1957. 
Basin characteristics, water supply, water use, floods, and the development of a comprehensive water plan are described.

5. An inventory of water resources and water problems, southern Iowa River basins: Iowa Nat. Resources Council Bull., no. 6, 70 p., 1958.

Basin characteristics, water supply, water use, flood control, and development of a comprehensive water plan are discussed.

6. An inventory of water resources and water problems, northeastern Iowa River

basins: Iowa Nat. Resources Council Bull., no. 7, 74 p., 1958.

Basin characteristics, water supply, water use, floods, and the development of a comprehensive water plan are discussed.

Ippen, Arthur T. See also Harleman, D. R. F.

1. (and Verma, Ramjee P.). Motion of particles on bed of a turbulent stream: Am. Soc. Civil Engineers Trans., v. 120, p. 921-938, 1955.

The experimental program was restricted to study of discrete particles (free to move) on a rough channel bed of fixed characteristics. Pertinent conclusions are drawn from the analytical and experimental results.

2. (and Raichlen, Frederic). Turbulence in civil engineering; measurements in free surface streams: Am. Soc. Civil Engineers Proc., v. 83, no. HY 5, Paper 1392, 27 p., 1957.

Turbulence phenomena were investigated by means of a combination of a totalhead tube and a pressure transducer. Design criteria and performance data for the instrument are given.

Irelan, Burdge. See Jones, P. H.

IrMAY, S.

On the theoretical derivation of Darcy and Forchheimer formulas: Am. Geophys. Union Trans., v. 39, p. 702-707, 1958.

Darcy's law is historically reviewed. (Discussion by John Happel; and author's reply, Jour. Geophys. Research, v. 61, p. 485-487, 1959.)

IRving, R. N.

(and Nelson, M. W.). Snow surveys made by and for water users: Soil Conserv., v. 21 , no. 8 , p. $180-183,1956$.

Water users measure snow-water content on Salmon Falls Creek basin, Idaho, and operate their farms on the basis of the water-supply forecasts.

IsAACSON, E.

(and Stoker, J. J., and Troesch, A.). Numerical solution of flow problems in rivers:

Am. Soc. Civil Engineers Proc., v. 84, no. HY 5, Paper 1810, 18 p., 1958.

New methods for dealing with flow problems in large rivers and reservoirs for periods of weeks are developed and tested.

IsHerwood, J. D.

(and Pillsbury, A. F.). Shallow ground water and tile drainage in the Oxnard Plain: Am. Geophys. Union Trans., v. 39, p. 1101-1110, 1958.

The hydrology of the shallow ground waters was studied by using a network of piezometers. The shape and rate of recession of the water table in tile-drained land and the tile effluent rate were measured. (Discussions by D. A. Kraijenhoff van de Leur, Max Bookman and R. G. Thomas; and authors' reply, Jour. Geophys. Research, v. 64 , p. 855-860, 1959.

ISRAELSEN, ORSON W.

The engineer and worldwide conservation of soil and water: Am. Soc. Civil Engineers Proc., v. 84, no. IR 3, Paper 1775, 22 p., 1958. 
The role of the engineer is emphasized, and a report on drainage systems and irrigation projects is presented.

IveY, JoHN B.

Geology and ground water in the Monroeville area, Alabama: Ala. State Geologist Bull. 66, 109 p., 1957.

The report contains detailed geologic and hydrologic data and information on the occurrence, availability, and chemical quality of the ground water.

Iwasa, Yoshiaki. See also Delleur, J. W.

Attenuation of solitary waves on a smooth bed: Am. Soc. Civil Engineers Proc., v. 83, no. HY 3, Paper 1262, 15 p., 1957.

The attenuation of solitary waves by viscous shear within the laminar boundary layer on a horizontal smooth bed is considered. (Author's corrections, v. 84, no. HY 1, Paper 1558, p. 41-42, 1958.)

Izzard, CARL F. See Kindsvater, C. E., 1; Tracy, H. J., 1.

JACKson, C. I.

Insolation and albedo in Quebec-Labrador: McGill Univ. Sub-arctic Research Lab. Paper, no. 5, 105 p., 1958.

JACOB, C. E. See Hantush, M. S., 1, 2, 3.

JaCoBsen, Thorkild.

(and Adams, Robert M.). Salt and silt in ancient Mesopotamian agriculture: Science, v. 128, no. 3334, p. 1251-1258, 1958.

Progressive changes in soil salinity and sedimentation contributed to the breakup of past civilizations.

JAEGER, C.

Economics of pumped storage: Eng. Jour., v. 41, no. 6, p. 67-74, 1958.

This paper deals with the economics of combined methods of power production and pumped storage, with a mathematical analysis of power systems. (Discussions by F. L. Lawton, I. W. McCaig, T. J. Hobson, and W. G. Lockett; and author's reply, v. 41 , no. 8 , p. $84-86,1958$.)

JAEGER, Edmund C.

The North American deserts: Stanford, Calif., Stanford Univ. Press, 308 p., 1957(?).

A survey was made of desert flora and fauna as related both to climate and topography.

JAEGER, J. C.

The measurement of thermal conductivity and diffusivity with cylindrical probes:

Am. Geophys. Union Trans., v. 39, p. 708-710, 1958.

The way which the temperature of a thermal-conductivity probe approaches its logarithmic asymptote is discussed. Previous results are questioned, and an improved method is described.

Jalichan, Nitipat. See LaMoreaux, P. E., 2.

James, George A. See Anderson, H. E.

JANES, Byron E. See Drinkwater, W. O.; Friedman, D. G.

JANSEN, Robert B.

Flow characteristics of the ogee spillway: Am. Soc. Civil Engineers Proc., v. 83, no. HY 6, Paper 1452, 11 p., 1957.

A formula for determining energy loss on an overflow spillway face is developed. A 
criterion for establishing the pattern of velocity variation along a level spillway apron is considered. (Discussion by Donald P. Thayer; and author's closure, v. 84, no. HY 6, Paper 1856, p. 25-37, 1958.)

Jeffery, H. G. See Geurin, J. W.

Jencks, Carlton E.

Analysis of February 1951 rain on snow in a densely forested area: U.S. Army Corps Engineers, North Pacific Div. Snow Inv. Research Note, no. 24, 23 p., 1955.

Jenkins, David S.

1. (and McNiesh, R. J., and Gottley, Sidney). Conversion of saline waters, in U.S. Department of Agriculture, Water: Yearbook of Agriculture 1955, p. $109-117$.

Various methods are described.

2. Developments in saline water conversion: Am. Water Works Assoc. Jour., v. 49 , no. 8 , p. $1007-1018,1957$.

The present status of several methods is described. (Discussion by Sheppard T. Powell.)

3. Fresh water from salt: Sci. Am., v. 196, no. 3, p. 37-45, 1957.

The need for more potable water and methods of desalinization are described and illustrated.

Jenkins, TARLETon A.

When the floods came again-watershed protection stood the test: Soil and Water, p. 8-11, June 1957.

The effectiveness of watershed conservation practices was demonstrated following the rains of April and May 1957.

Jochens, E. R. See Bjorklund, L. J., 3; Moulder, E. A.; Tychsen, P. C.

Johansen, R. T.

(and Dunning, H. N.). Direct evaluation of water sensitivity of reservoir rocks: U.S. Bur. Mines Rept. Invest. 5422, 9 p., 1958.

Correlations of nitrogen and water-vapor adsorption studies with clay analyses and permeability measurements show that the water-vapor adsorption method is a promising means for the direct measurement of the water sensitivity of sedimentary formations.

Johnson, Albert R. See Krutilla, J.

Johnson, Arthur. See Weld, B. A.

Johnson, Arthur H.

Conservation of ground water on Long Island: Am. Water Works Assoc. Jour., v. 47 , no. 4, p. 348-354, 1955.

A brief history of ground-water use and a description of the required practice of returning cooling water to the aquifer are given.

Johnson, Carlton R. See also Bradley, E., 2, 3.

Geology and ground-water resources of Logan County, Kansas: Kans. Geol. Survey Bull. 129, 175 p., 1958.

Johnson, Curmis E. See also Schiff, L., 2, 4.

Utilizing the decomposition of organic residues to increase infiltration rates in water spreading: Am. Geophys. Union Trans., v. 38, p. 326-332, 1957.

Results of a field experiment with various residues are given. 
Johnson, Edward A.

1. (and Dils, Robert E.). Outline for compiling precipitation, runoff, and groundwater data from small watersheds: U.S. Forest Service, Southeastern Forest Expt. Sta. Paper 68, 40 p., 1956. (Revision Tech. Note No. 34, by C. R. Hursh, 1938.)

Systematic methods and forms for compiling basic hydrologic data are given.

2. (and Kovner, Jacob L.). Effect on streamflow of cutting a forest understory: Forest Sci., v. 2, no. 2, p. 82-91, 1956.

Records were obtained of precipitation and streamflow from 1941 to 1955 on two contiguous forested basins in Coweeta Experimental Forest. In 1948 the laurelrhododendron understory was cut. Statistical analyses indicate an average annual increase in streamflow following the cutting of 4 percent. Increases were also found for the growing and dormant seasons.

Johnson, F. A. See Langbein, W. B., 1.

Johnson, H. P. See also Barnes, K. K.

(and Howe, J. W.). Infiltration frequency on Ralston Creek watershed: Am. Geophys. Union Trans., v. 37, p. 593-594, 1956.

The frequency of occurrence of infiltration rates as indicated by an infiltration index was computed.

Johnson, J. W. See Einstein, H. A., 3; Sibul, O. J.

Johnson, Oliver.

Snow hydrology summary report: Western Snow Conf. Proc., p. 42-43, Apr. 1956.

This is an outline of a Corps of Engineers report.

Johnson, P. W.

(and White, N. D., and Cahill, J. M.). Pumpage and ground-water levels in

Arizona in 1955: Ariz. Land Dept. Water Resources Rept., no. 1, 69 p., 1956.

The purpose of the water-level program is reviewed, and the data are given both in graphical and tabular form.

Johnson, R. W.

Determination of the $0.02 \mathrm{~mm}$. fraction in granular soils: Am. Soc. Civil Engineers Proc., v. 83, no. SM 3, Paper 1309, 10 p., 1957.

A method based on statistical analysis is used. Results of tests on 24 granular soils are given. (Discussions by H. Y. Fang, v. 83, no. SM 4, Paper 1430, p. 35-42, 1957; Irving Sherman, v. 84, no. SM 1, Paper 1559, p. 9, 1958; and author's closure, v. 84, no. SM 4, Paper 1828, p. 3, 1958.)

Johnson, Wendell E.

1. The Missouri River reservoir system: Am. Water Works Assoc. Jour., v. 48, no. 8, p. 942-951, 1956.

A brief description of the system is given.

2. Missouri River Basin plan in operation: Am. Soc. Civil Engineers Trans., v. 122, p. 654-665, 1957.

The effect of reservoirs on floods and droughts is shown.

JoIinson, WiLLiam M.

Water resources problems in Virginia: Am. Water Works Assoc. Jour., v. 49, no. 1, p. 68-69, 1957.

Problems were defined at public hearings throughout the State. (Discussion by

Oral H. Hert and Charles H. Bechert.)

Jones, B. O. See Eschner, A. R. 
Jones, D. A. See Rich, L. G.

Jones, D. M. A. See Huff, F. A., 8.

JoNes, DAN S.

Nebraska water legislation and associated administrative problems: Am. Water Works Assoc. Jour., v. 48, no. 8, p. 993-998, 1956.

Background, present provisions, and administrative problems related to power and irrigation are given.

Jones, Paul H.

(and Hendricks, E. L., and Irelan, Burdge). Water resources of southwestern Louisiana: U.S. Geol. Survey Water-Supply Paper 1364, 460 p., 1956.

This report describes the followirg: The rice industry in Louisiana, climate, physiography, geology, surface-water resources, ground-water resources, and quality of the water. Thirty-eight plates are in plate volume.

Jones, Victor H. See Gottschalk, L. C., 1.

JordaAn, JAN M., JR. See Chien, N., 1.

JORDAN, J. V.

(and Lewis, G. C., and Fosberg, M. A.). Tracing moisture movement in slick-spot soils with radiosulfur; Part 1: Am. Geophys. Union Trans., v. 39, p. 446-450, 1958.

Techniques based on laboratory and field experiments have been developed for studying moisture movement in slick-spot soils. The objective is control or eradication of the slick spots.

Jordan, P. R. See Mundorff, J. C.

Judson, Sheldon.

(and Osmond, J. Kenneth). Radioactivity in ground and surface water: Am. Jour. Sci., v. 253, no. 2, p. 104-116, 1955.

Values for uranium content and total radioactivity of some underground and surface waters from 77 localities are presented. Uranium content ranges from 0.02 to 460 parts per billion.

Jumikis, A. R.

The method of solution of Ruckli's frost-penetration equation: Am. Geophys. Union Trans., v. 37, p. 181-184, 1956.

A method of solving a nonlinear differential equation is given.

Kabelac, Otakar W.

Rivers under influence of terrestrial rotation: Am. Soc. Civil Engineers Proc., v. 83, no. WW 1, Paper 1208, 16 p., 1957.

The mathematical evaluation of forces involved in the formation of river beds, according to the Law of Baer, is outlined. (Discussion by Gerard Tison, Jr., v. 83, no. WW 3, Paper 1381, p. 7-11, 1957; and author's closure, v. 84, no. WW 1, Paper 1523, p. 7-11, 1958.)

Kandaswamy, P. K. See also Stall, J. B.

(and Rouse, Hunter). Characteristics of flow over terminal weirs and sills: Am. Soc. Civil Engineers Proc., v. 83, no. HY 4, Paper 1345, 13 p., 1957.

Experimental results show the variation in both discharge coefficient and nappe profile for two-dimensional flow over a sharp-crested weir as the ratio of head to depth changes from zero to unity. (Discussions by F. V. A. Engel, v. 84, no. HY 1, Paper 1558, p. 59-60, 1958; F. Paderi; and authors' closure, v. 84, no. HY 5, Paper 
1832, p. 51-54, 1958. Corrections to Paderi's discussion, v. 85, no. HY 2, Paper 1950, p. 85-86, 1959.)

Kansas Law Review.

Symposium on water law: Kans. Univ. Law Rev., v. 5, no. 4, p. 491-674, 1957. Report contains 10 papers on water policies, problems, and rights in Kansas.

Kansas Water Resources Board.

1. Report on the laws of Kansas pertaining to the beneficial use of water: Kans. Water Resources Board Bull. 3, 153 p., 1956.

2. A survey of programs of state financial participation in water projects: Kans. Water Resources Board, 34 p., 1957.

Report describes financial participation in general and specifically by States. Also included is a section on the problems and attitudes toward the proper role of the State in water projects (for 20 States).

3. Preliminary appraisal of Kansas water problems, Section 1, Marias Des Cygnes

Unit: Kans. Water Resources Board Water Plan Study, 189 p., 1958.

This report considers hydrology, present water uses and future requirements, demand versus surface-water supply, water-control problems, and water legislation.

4. Preliminary appraisal of Kansas water problems, Section 2, Cimarron Unit:

Kans. Water Resources Board Water Plan Study, 124 p., 1958.

This report considers hydrology, water use (present and future), demand versus ground-water supply, surface-water control problems, ground-water legislation, and administrative problems.

Kansas Water Resources Fact-Finding and Research Committee.

Water in Kansas, 1955: Kans. Water Resources Fact-Finding and Research Comm., 216 p., 1955.

A statewide survey-agricultural, municipal, and industrial.

Karlstrom, Thor N. V. See Hopkins, D. M.

Kaser, Paul. See also Williams, L. G., 1.

Report of investigation, ground-water levels in the vicinity of Leipsic, Ohio: Ohio Div. Water Inf. Circ. 6, 16 p., 1958.

Katz, Abraham.

Measuring yield of drilled wells without pumping: Am. Water Works Assoc. Jour., v. 47, no. 6 , p. 537-548, 1955.

The method described utilizes a bailer with an electric water-level indicator.

Kaufman, Robert I. See Mansur, C. I., 1.

KaUfMaN, WarRen J.

1. (and Orlob, G. T.). An evaluation of ground-water tracers: Am. Geophys. Union Trans., v. 37, p. 297-306, 1956.

Cationic materials, anionic radioisotopes, chloride, organic materials, and tritium were studied. None is completely satisfactory for every situation.

2. (and Orlob, Gerald T.). Measuring ground water movement with radioactive and chemical tracers: Am. Water Works Assoc. Jour., v. 48, no. 5, p. 559-572, 1956.

The various tracers used are described.

KaUtz, Harold $M$.

The story of the Sandstone Creek watershed, in U.S. Department of Agriculture,

Water: Yearbook of Agriculture 1955, p. 210-218. 
The report describes a watershed plan designed to reduce erosion and flood-water damages. Success of the plan is demonstrated by the disposition of runoff from two severe storms.

Kazmann, Raphael G. See also Loehnberg, A., 1.

1. "Safe yield" in ground water development, reality or illusion?: Am. Soc. Civil Engineers Proc., v. 82, no. IR 3, Paper 1103, 12 p., 1956.

The definition of safe yield is found inadequate. A more feasible approach to the problem of ground-water control, based on the functional utilization of aquifers, is proposed. (Discussions by C. L. McGuinness, J. G. Ferris, Meyer Kramsky, v. 83, no. IR 1, Paper 1257, p. 9-14, 1957; and author's closure, v. 83, no. IR 2, Paper 1377, p. 5-7, 1957.)

2. Problems encountered in the utilization of ground-water reservoirs: Am. Geophys. Union Trans., v. 39, p. 94-99, 1958.

Ground-water reservoirs are compared to surface-water reservoirs, and the similarities and differences are described. Examples of problems found in the utilization of ground-water reservoirs are cited. (Discussions by Harold Conkling and H. W. Thomas; and author's closure, v. 39, p. 1163-1165, 1958.)

Keifer, Clint J.

(and Chu, Henry Hsien). Synthetic storm pattern for drainage design: Am. Soc.

Civil Engineers Proc., v. 83, no. HY 4, Paper 1332, 25 p., 1957.

A method of deriving a synthetic storm pattern from local rainfall records is presented for use in the hydrograph method of drainage design. (Discussion by M. B. McPherson, v. 84, no. HY 1, Paper 1558, p. 49-51, 1958.)

Keighton, W. B. See Durfor, C. N.

Keller, M. Dean. See Carey, W. C.

Kelley, Omer J. See Salter, R. M.

Kelly, Ludwig L. See Allis, J. A.

Kempton, John P. See Selkregg, L. F.

KendREw, W. G.

(and Currie, B. W.). The climate of central Canada: Ottawa, Edmond Cloutier, Queen's Printer and Controller of Stationery, 194 p., 1955.

Report contains a general description of the area and specific descriptions of the Mackenzie Basin, the Barren Grounds, the Forest and Parkland Areas of Alberta, the Prairie Grasslands, and Manitoba. Some tabular data are included.

Kennedy, David V. See Reynolds, R. R.

Kennedy, John F. See Cariño, I. D.

Kennedy, Richard A. See Knowles, D. B.

Kenner, William E. See also Brown, D. W., 2.

(and Brown, Eugene). Interim report on surface-water resources and quality of waters in Lee County, Florida: Fla. Geol. Survey Inf. Circ., no 7, 69 p., 1956.

This report provides information on the location, variations in supply, and quality of surface waters and means for increasing this information.

Kentucky Departaent of Economic Development.

Streamflow in Kentucky: Ky. Dept. Econ. Devel., 91 p., 1956.

Report contains flood stages and discharges, annual mean discharges, minimum daily and monthly discharges, stream discharges during the drought of 1953, and temperatures of surface waters. 
Kentucky Legislative Research Commission.

Flood insurance and flood-plain zoning: Ky. Gen. Assembly, 31 p., 1957.

KerR, RAYmond E., JR.

Reservoir evaporation control: Western Snow Conf. Proc., p. 15-18, Apr. 1957.

The use of monomolecular films is reviewed.

Kidder, E. H. See Ash, A. S.

Kindsvater, Carl E.

1. (and Carter, Rolland W.). Tranquil flow through open-channel constrictions: Am. Soc. Civil Engineers Trans., v. 120, p. 955-980, 1955.

The bridge waterway is studied in the basic research described in this paper. The flow pattern due to an area restriction is not subject to a general analytical solution. A practicable solution of the discharge equation has been achieved by the application of a systematic experimental investigation to an approximate analysis. Experimental data, which extend the solution to a wide variety of boundary conditions, are presented in dimensionless graphical form. (Discussion by Emmett M. Laursen and Arthur Toch, Fred W. Blaisdell, Pin-Nam Lin, Carl F. Izzard, and Chesley J. Posey.)

2. (and Carter, Rolland W.). Discharge characteristics of rectangular thin-plate weirs: Am. Soc. Civil Engineers Proc., v. 83, no. HY 6, Paper 1453, 36 p., 1957.

A solution for discharge characteristics is based on a simple equation of discharge and experimentally derived coefficients. The solution is compared with those from other experiments and formulas. (Discussions by Turgut Sarpkaya, v. 84, no. HY 2, Paper 1616, p. 93-100, 1958; Steponas Kolupaila, Ralph W. Powell, John W. Paull, Iwao Oki, v. 84, no. HY 3, Paper 1690, p. 21-30, 1958; M. R. Carstens, v. 84, no. HY 6, Paper 1856, p. 39-41, 1958; and authors' closure, v. 85, no. HY 3, Paper 1989, p. 45-49, 1959.)

3. Selected topics of fluid mechanics: U.S. Geol. Survey Water-Supply Paper 1369-A, p. 1-51, 1958.

The fundamental equations of fluid mechanics are developed with sufficient rigor to support examinations of their applicability to problems of river hydraulics.

KING, K. M.

(and Tanner, C. B., and Suomi, V. E.). A floating lysimeter and its evaporation recorder: Am. Geophys. Union Trans., v. 37, p. 738-742, 1956.

A weighing lysimeter is described which has been used to obtain continuous values of evapotranspiration from an irrigated pasture. (Discussions by L. L. Harrold and F. R. Dreibelbis, D. B. Krimgold; and authors' closure, v. 38 , p. $765-768,1957$.

Kinnison, Phibip T.

A survey of the ground water of the State of Idaho: Idaho Bur. Mines and Geology Pamph., no. 103, 40 p., 1955.

Report describes the three ground-water environments in Idaho and the occurrence and utilization of ground water by regions.

Kirkham, Don. See also Adams, J. E.; Burrows, W. C.; Stone, J. F.; Swartzendruber, D., 1, 2.

Seepage of steady rainfall through soil into drains: Am. Geophys. Union Trans., v. 39 , p. 892-908, 1958.

A theoretical solution is developed, and the results compared with field data. Agreement is good. The analysis presents a rational foundation for the DupuitForchheimer theory. 
KIster, L. R. See Babcock, H. M.; Eddards, M. L.; Winslow, A. G., 1.

Kittredge, Joseph.

Litter and forest floor of the chaparral in parts of the San Dimas Experimental Forest, California: Hilgardia, v. 23, no. 13, 1955.

Klein, Howard.

Interim report on salt-water encroachment in Dade County, Florida: Fla. Geol. Survey Inf. Circ., no. 9, 17 p., 1957.

The effect on the ground-water resources of digging canals is described.

KLein, Louis.

Aspects of river pollution: New York, Academic Press Inc., 621 p., 1957.

The report was written primarily from the standpoint of British practice. It is a comprehensive treatment except for the subjects of corrosion and pollution of tidal waters.

KLeIN, William H.

Principal tracks and mean frequencies of cyclones and anticyclones in the northern hemisphere: U.S. Weather Bur. Research Paper No. 40, 60 p., 1957.

The background, basis for, and significance of the charts of tracks and frequencies are presented.

KLUG, Mervin L.

Geology and ground-water resources of the Alexandria area, Rapides Parish, Louisiana: La. Geol. Survey Water Resources Pamph., no. 3, 23 p., 1955.

Knapp, Robert T. See Baumann, P.

KNowles, Doyle B.

(and Kennedy, Richard A.). Ground-water resources of the Hueco Bolson northeast of El Paso, Texas: U.S. Geol. Survey Water-Supply Paper 1426, 186 p., 1958.

This reports (1) the thickness and areal extent of the bolson deposits which contain fresh water, (2) the capacity of the deposits to absorb, store, and transmit water, and (3) the chemical character of the ground water.

Knox, C. E.

1. Index of surface-water records to September 30, 1955, part 1, North Atlantic slope basins: U.S. Geol. Survey Circ. 381, 30 p., 1956.

The index gives the drainage area and period of record.

2. Index of surface-water records to September 30, 1955, part 4, St. Lawrence River basin: U.S. Geol. Survey Circ. 384, 15 p., 1956.

The index gives the drainage area and period of record.

Knox, Homer. See Williams, L. G., 1.

Koberg, Gordon E. See Harbeck, G. E., Jr., 3.

Koch, A. Arthur.

Some physical problems related to flood insurance: Am. Soc. Civil Engineers Proc., v. 83, no. HY 1, Paper 1164, 5 p., 1957.

Technical problems in the fields of meteorology, hydrology, and oceanography as related to a nation-wide flood-insurance program are described.

Kochititzky, Oscar W. See Garner, J. M., JR.

Koelzer, Victor A.

1. (and Ford, Perry M.). Effect of various hydroclimatic factors on snowmelt runoff: Am. Geophys. Union Trans., v. 37, p. 578-587, 1956. 
The influence of various climatic factors on snowmelt runoff was determined through 583 multiple correlations. The superiority of using both precipitation and snowsurvey data was indicated. (Discussions by Willard M. Snyder and Donald W. Kuehl; and authors' closure, v. 38, p. 773-777, 1957.)

2. The use of statistics in reservoir operations: Am. Soc. Civil Engineers Trans., v. 122, p. 1187-1201, 1957.

The development of annual operating plans for reservoir systems deriving their primary water supply from snowmelt, as well as progressive, seasonal modifications to these plans, is given.

3. (and Lara, Joe M.). Densities and compaction rates of deposited sediment: Am. Soc. Civil Engineers Proc., v. 84, no. HY 2, Paper 1603, 15 p., 1958.

Important work concerning density and consolidation of sediment deposited in reservoirs and applicable work in soil mechanics is reviewed.

Koeppe, Clarence E.

(and DeLong, George C.). Weather and climate: New York, McGraw-Hill Book Co., 341 p., 1958.

This is a reasonably complete nontechnical college-level treatment of modern weather principles and processes and a clear application of those principles and processes to the field of climate.

Koffman, Louis A. See Miller, J. F.

KOHLER, KARL O., JR.

Trends in the utilization of water, in U.S. Department of Agriculture, Water: Yearbook of Agriculture 1955, p. 35-40.

A general discussion of the problem is presented.

Kohler, Max A. See also Drinkwater, W. O.; Harbeck, G. E., Jr., 3; Kuiper, E.; Linsley, R. K., Jr., 3; Snyder, F. F., 2.

1. (and Nordenson, T. J., and Fox, W. E.). Evaporation from pans and lakes: U.S. Weather Bur. Research Paper, no. 38, 21 p., 1955.

An empirical relation is developed, and nomograms are presented relating lake evaporation to pertinent meteorological factors such as wind movement, elevation, water and air temperature, solar radiation, vapor-pressure gradient, and pan evaporation.

2. River and water-supply forecasting: N.Y. Acad. Sci. Trans., ser. 2, v. 18, no. 8, p. 732-745, 1956.

Methods used by the U.S. Weather Bureau in forecasting flood hydrographs at more than 1,000 localities over the Nation are given.

3. Water-supply forecasting developments, 1951-1956: Western Snow Conf. Proc., p. 62-68, Apr. 1957.

Advantages of the water-year budget over the April-September budget and suggestions for improving forecasts are given. An annotated bibliography is included.

4. Mechanical analogs aid graphical flood routing: Am. Soc. Civil Engineers Proc., v. 84, no. HY 2, Paper 1585, 14 p., 1958.

Graphical techniques for routing directly on plotted hydrographs are described. A mechanical analog has been constructed which will accommodate the use of the graphical relations. (Discussion by C. O. Clark, v. 85, no. HY 1, Paper 1919, p. 99-104, 1959; and authors' closure, v. 85, no. HY 5, Paper 2045, p. 179, 1959.)

Kohnke, Henmut. See Domby, C. W.

Kоноuт, Francis A. See also Moulder, E. A.; Torrey, A. E.

Geology and ground-water resources of the Kaycee irrigation project, Johnson 
County, Wyoming, with a section on chemical quality of the ground water, by F. H. Rainwater: U.S. Geol. Survey Water-Supply Paper 1360-E, p. 321-374, 1957.

Present conditions are described, and the effect on the ground-water table of irrigating additional land in the area is considered.

Kolb, C. R.

(and Shockley, W. G.). Mississippi Valley geology-its engineering significance:

Am. Soc. Civil Engineers Proc., v. 83, no. SM 3, Paper 1289, 14 p., 1957.

The various environments of alluvial deposition and the resulting soil formations are discussed, particularly with relation to engineering problems. (Discussion by Shu-T'Len Li, v. 83, no. SM 3, Paper 1319, p. 35-46, 1957; and authors' closure, v. 85 , no. SM 2, Paper 2011, p. 105, 1959.)

Kolupaila, Steponas. See Cariño, I. D.; Foster, H. A., 1; Kindsvater, C. E., 2; Moore, A. M.; Stevens, J. C.; Thomas, C. W.

Koopman, F. C.

Ground water in the Crow Creek-Sand Lake area, Brown and Marshall Counties, South Dakota: U.S. Geol. Survey Water-Supply Paper 1425, 125 p., 1957.

This is the report of an investigation to ascertain the extent of flooding and waterlogging in the subject area and to relate the flooding and waterlogging to the occurrence and movement of ground water.

Koranda, J. J. See Drew, J. V.

Kovner, JACoB L. See also Johnson, E. A., 2.

1. Evapotranspiration and water yields following forest cutting and natural regrowth: Soc. Am. Foresters Proc., p. 106-110, 1956.

Cutting all vegetation on a well-forested watershed produced very large increases in streamflow.

2. Evapotranspiration in forest stands of the southern Appalachian Mountains:

Ga. Acad. Sci. Bull., v. 15, no. 3, p. 80-85, 1957.

The relations of evapotranspiration to precipitation, to vegetal cover, and to time of year are described.

Kozachyn, John. See Woodburn, R., 2, 3.

Kraebel, Charles J.

Conquering Kennett's gullies: Am. Forests, v. 61, no. 12, p. 36-39, 42, 44, 1955.

The report describes the killing of forest cover by smelter fumes 50 years ago in northern California, subsequent erosion of the bared slopes, studies that developed successful methods of reforestation and erosion control, and recent application of methods on the area.

Kraft, R. H. See Conner, W. C.

Kraijenhoff van de Leur, D. A. See Boyer, M. C., 1; Isherwood, J. D.

Kramer, Harry P.

(and Moeller, Dade W., and Pecsok, Donald A.). Radioactivity in surface water:

Am. Water Works Assoc. Jour., v. 50, no. 11, p. 1516-1522, 1958.

Water monitoring is necessary to establish the natural radioactivity and to identify exposure levels from other sources.

Kramer, Paul J. See Veihmeyer, F. J., 1.

Kramsky, Meyer. See Kazmann, R. G., 1. 


\section{Krause, KeIth S.}

Water quality studies in the Arkansas and Red River basins: Am. Water Works Assoc. Jour., v. 50, no. 9, p. 1166-1170, 1958.

Data were collected in the basins for identification of waters of varying quality. Improvement of quality will be the next step. (Discussion by Dwight F. Metzler.)

Kresge, RalPh F.

1. (and Nordenson, Tor J.). Flood frequencies derived from river forecasting procedures: Am. Soc. Civil Engineers Proc., v. 81, Separate 630, 16 p., 1955.

Records of annual peak discharges are extended through use of precipitation data and a river-forecasting procedure. The extended record is used to define the magnitude-frequency relation. The result is superior to the relation defined from the unextended record.

2. Report on comparison of shielded and non-shielded precipitation gage study: Eastern Snow Conf. Proc., v. 4, p. 124-128, 1957.

This is a progress report based on data being obtained in northern Lake Michigan.

KRICK, Irving P.

1. Results of cloud-seeding operations to augment municipal water supplies: Am. Water Works Assoc. Jour., v. 48, no. 10, p. 1250-1264, 1956.

Case histories of seeding at Dallas, Oklahoma City, Springfield, and Shreveport are given.

2. A new source of underground water: Water Well Jour., v. 11, no. 11, 1957. Cloud seeding may be a feasible method of increasing ground-water supplies.

\section{Krieger, James $\mathrm{H}$.}

Progress in ground water replenishment in southern California: Am. Water Works Assoc. Jour., v. 47, no. 9, p. 909-913, 1955.

A discussion of the legal problems is presented.

Krieger, Robert A. See also Bradley, E., 2; Collier, C. R.; Cronin, J. G.; Newport, T. G.

(and Hatchett, J. L., and Poole, J. L.). Preliminary survey of the saline-water resources of the United States: U.S. Geol. Survey Water-Supply Paper 1374, 172 p., 1957.

The report gives a discussion of salinity and a compilation of measurements and chemical analyses of saline ground and surface waters, with an emphasis on their geographic and geologic distribution.

Krimgold, D. B. See also King, K. M.

(and Shahori, Ami). Design rain-aid in erosion control studies: Agr. Eng., v. 38, no. 10, p. 740-743, 1957.

The once-in-10-years runoff and erosion were reproduced by a sprinkling system in Israel.

Kristuanson, KrIs. See Krutilla, J.

Krone, R. B.

(and McGauhey, P. H., and Gotaas, H. B.). Direct recharge of ground water with sewage effluents: Am. Soc. Civil Engineers Proc., v. 83, no. SA 4, Paper 1335, 25 p., 1957.

Results are presented of a 3-year field study in which sewage effluents were injected into a confined aquifer, and the travel of pollution was observed in 23 wells. (Discussion by Ralph Stone, v. 83, no. SA 6, Paper 1466, p. 7-8, 1957.) 
Krumbein, W. C.

(and Lieblein, Julius). Geological application of extreme-value methods to interpretation of cobbles and boulders in gravel deposits: Am. Geophys. Union Trans., v. 37, p. 313-319, 1956.

Unusually large boulders in a gravel deposit are shown to be normal members of the stream-pebble population if an extreme-value distribution is assumed.

Krutilla, John, and others.

River basin development: Jour. Farm Economics, v. 40, no. 5, p. 1674-1716, 1958. The author and the title of the paper that he presented at the symposium follow: John Krutilla, "Planning and Evaluation"; Albert R. Johnson, "Discussion: Some Recent Developments in River Basin Planning for Evaluation"; Mark M. Regan, "Sharing Financial Responsibility of River Basin Development"; George S. Tolley, "Discussion: Sharing Financial Responsibility of River Basin Development"; Kris Kristjanson, "Organization for River Basin Development: The Columbia River"; Stephen C. Smith, "Discussion: Organization for River Basin Development-The Columbia River." These subjects are treated with special application to international streams.

KUDER, W. B.

Legal problems in water resources-a symposium: Calif. Law Rev., v. 45, 584 p., Dec. 1957.

The author and the title of the paper that he presented at the symposium follow: A. Moskovitz, "Water Rights and Federalism in the Western Water Rights Settlement Bill of 1957"; C. E. Corker, "Government Ownership and Trusteeship of Water"; F. J. Trelease, "Western Interstate Water Compacts"; H. R. Stinson, "The Evolution of Forms of Water Users Organizations in California"; A. T. Henley, "Procedures and Practice Before the California State Water Rights Board"; H. Holsinger, "California Ground Water: Legal Problems"; W. A. Hutchins, "Weather Modification: Water Three Cents Per Acre-Foot?" Federal, State, or local cooperation in conservation and development of water resources is discussed in the following papers: D. D. Stark, "The Role of the Federal Government"; E. F. Bennett, "The Role of the State"; P. A. Towner, "The Role of the Public Power District"; E. K. Davis, "The Role of the Private Power Company."

Kuehl, Donald W. See Koelzer, V. A., 1.

Kuenen, P. H.

Realms of water: New York, John Wiley and Sons, 327 p., 1956.

This book deals with the various features of physical geology, meteorology, oceanography, and glaciology as they apply to water and its movements. The chapters on atmospheric water, ground water, and surface water will be of most interest to hydrologists.

Kuiper, E. See also Lane, E. W., 1; Lawlor, W. F.; Matthes, G. H.

100 frequency curves of North American rivers: Am. Soc. Civil Engineers Proc., v. 83, no. HY 5, Paper 1395, 31 p., 1957.

Frequency curves of annual maximum flows are drawn as straight lines. The inclinations of the lines are functions of basin characteristics. (Discussions by H. C. Riggs, v. 84, no. HY 1, Paper 1558, p. 61-63, 1958; G. N. Alexander, Max A. Kohler, Ralph W. Powell, v. 84, no. HY 2, Paper 1616, p. 19-24, 1958; and author's closure, v. 84, no. HY 5, Paper 1832, p. 59-60, 1958.)

Kunkel, Fred. See Upson, J. E., 2. 
Kurz, Herman.

(and Wagner, Kenneth). Tidal marshes of the Gulf and Atlantic coasts of northern Florida and Charleston, South Carolina: Fla. State Univ. Studies no. 24, 168 p., 1957.

The report describes geology, elevations, soil factors, water relations, and plant zonation and succession.

Kuzmak, J. M. See Woodside, W.

Lacey, Gerald. See Chien, N., 3.

LaChapelle, E. See also Thiel, E.

Winter snow observation on Mt. Olympus: Western Snow Conf. Proc., p. 59-63, Apr. 1958.

Temperature, precipitation, snowfall, snow depth, and new-snow density are given.

Lachenbruch, Arthur H.

A probe for measurement of thermal conductivity of frozen soils in place: Am. Geophys. Union Trans., v. 38, p. 691-697, 1957.

The theory of the probe method, a description of the instrument, and results of its use are given. (Discussion by William Woodside; and author's closure, v. 39, p. $730-732,1958$.

LACKey, James B.

Effects of fertilization on receiving waters: Sewage and Indus. Wastes, v. 30, no. 11, p. 1411-1416, 1958.

A general discussion is given of the effects of introducing raw sewage on effluents from sewage-treatment plants to streams.

LaDue, Wendell R. See Belcher, P.

Lamar, William L.

1. (and Drake, Paul G.). Factors affecting the determination of fluoride in water with zirconium-alizarin: Am. Water Works Assoc. Jour., v. 47, no. 6, p. 563$572,1955$.

Methods of analysis are described for various types of samples. (Correction, v. 47 , no. 9 , p. 839,1955 .)

2. (and Collier, Charles R.). Suspended sediment characteristics of Ohio streams: Jour. Soil and Water Conserv., v. 11, no. 5, p. 233-237, 1956.

A description of sediment studies being conducted on Ohio streams is given, and their value in planning erosion control measures is described.

Lamb, Owen P. See Straub, L. G., 2.

LaMoreaux, P. E.

1. (and Toulmin, L. D., and Sutcliffe, Horace, Jr.). Interim report on the geology and ground-water resources of Wilcox County, Alabama: Ala. State Geologist Inf. Ser. 8, 17 p., 1957.

2. (and Charaljavanaphet, Jumchet; Jalichan, Nitipat; Chiengmai, Phong Phan Na; Bunnag, Din; Thavrisi, Adul; and Rakprathum, Chumphon). Reconnaissance of the geology and ground water of the Khorat Plateau, Thailand: U.S. Geol. Survey Water-Supply Paper 1429, 62 p., 1958.

This is a report of a 1954 reconnaissance with special reference to the development of ground-water supplies for public and domestic use and the location of potential sources of water for proposed industrial and irrigation use.

Lamp, George E. See Matson, H. O. 
Landenberger, Edgar W. See Gilcrest, B. R.

LANDSBERG, H. E.

Trends in climatology: Science, v. 128, no. 3327, p. 749-758, 1958.

The investigation of climates is changing from a descriptive science to one based on physics.

Lane, Charles W. See Stramel, G. J., 3.

Lane, Emory W. See also Chien, N., 2, 3.

1. The importance of fluvial morphology in hydraulic engineering: Am. Soc. Civil Engineers Proc., v. 81, Paper 745, 17 p., 1955.

The stages of development of a river, the base level to which many streams approach, and the tendency to reach channel equilibrium are features to be considered. Changes in stream profile are classified and illustrated. (Discussions by E. Kuiper, W. H. R. Nimmo, v. 82, no. HY 1, Paper 881, p. 37-41, 1956; Stafford C. Happ, v. 82, no. HY 2, Paper 955, p. 3-6, 1956, and author's closure, v. 82, no. HY 5, Paper 1092, p. 5-8, 1956.)

2. Design of stable channels: Am. Soc. Civil Engineers Trans., v. 120, p. 1234$1260,1955$.

This paper reports the results of preliminary studies by the U.S. Bureau of Reclamation to improve the design of irrigation canals constructed in earth. Future investigations are outlined. (Discussion by Serge Leliavsky, A. Nizery and G. Braudeau, N. K. Bose, and Jose S. Gandolfo.)

Lang, Joe W. See also Harvey, E. J., 2.

(and Robinson, W. H.). Summary of the water resources of the Hattiesburg,

Laurel, and Pascagoula areas, Mississippi: Miss. Board Water Commissioners Bull. 58-2, 16 p., 1958.

Lang, Solomon M. See Remson, I., 2; Barksdale, H. C., 1, 2.

Langbein, Walter B. See also Hoyt, W. G.

1. (and Hardison, C. H.). Extending streamflow data: Am. Soc. Civil Engineers Proc., v. 81, Paper 826, 13 p., 1955.

To provide more information for water projects, correlation between discharges of streams may be used. A graphical method of correlation for this purpose is developed. General use of the method will lead to redesign of the gaging-station network. (Discussions by R. D. Goodrich, Carroll F. Merriam and E. T. Schuleen, Willard M. Snyder, v. 82, no. HY 2, Paper 955, p. 33-39, 1956; F. A. Johnson, v. 82, no. HY 4, Paper 1041, p. 21-29, 1956; authors' closure, v. 83, no. HY 1, Paper 1177, p. 5-7, 1957.)

2. (and Wells, J. V. B.). The water in the rivers and creeks, in U.S. Department of Agriculture, Water: Yearbook of Agriculture 1955, p. 52-62.

Variations in runoff throughout the United States are described, and the principles of stream gaging are given.

3. (and Schumm, S. A.). Yield of sediment in relation to mean annual precipitation: Am. Geophys. Union Trans., v. 39, p. 1076-1084, 1958.

Effective mean annual precipitation is related to sediment yield from drainage basins throughout the United States. The relation of relative erosion to vegetative density and the effect of a change in precipitation on bulk density of vegetation are shown. Effects of climatic change on sediment yield are suggested.

4. Divining rods versus hydrologic data and research: Am. Soc. Civil Engineers Proc., v. 84, no. HY 5, Paper 1809, 6 p., 1958.

The divining rod as a basis for hydrologic decisions is contrasted with basic-data 
programs. Gaps in basic data are discussed, and the need for research and interpretation is emphasized. (Discussions by Ven Te Chow, v. 85, no. HY 3, Paper 1989, p. 65-66, 1959; Erhard E. Dittbrenner, V. M. Yevdjevich, v. 85, no. HY 4, Paper 2012 , p. 113-115, 1959; and author's closure, v. 85, no. HY 8, Paper 2138, p. 89, 1959.)

5. Queuing theory and water storage: Am. Soc. Civil Engineers Proc., v. 84, no. HY 5, Paper 1811, 21 p., 1958.

A method for computing the required storage for regulating streamflow is developed on the basis of analogies with queues. (Discussion by B. W. Gould, v. 85, no. HY 4, Paper 2012, p. 117-119, 1959; and author's closure, v. 85, no. HY 8, Paper 2138, p. 91-93, 1959.)

6. (and Alexander, G. N.). How to figure odds on a river project: Eng. NewsRec., v. 161, no. 9, p. 35-36, Aug. 28, 1958.

A method of relating benefits to probability is described. (Discussion by Gordon R. Williams; and author's reply, v. 161 , no. 20 , p. 6 , Nov. 13, 1958; N. J. Cochrane, v. 161 , no. 22 , p. 8 , Nov. 27,1958 .)

LANGFord, R. H. See Robinove, C. J.

LANPhERE, C. R.

Geologic source and chemical quality of public ground-water supplies in western

Tennessee: Tenn. Div. Geology Rept. Inv., no. 1, 69 p., 1955.

Report gives mostly data on quality of individual supplies.

Lansford, Wallace M. See Straub, L. G., 1.

Lara, G. Cohen de. See Petersen, J. S.

Lara, Joe M. See Chien, N., 1; Koelzer, V. A., 3.

Larson, Bernt O. See also Larson, T. E., 2, 3.

(and Hiser, Homer W., and Daniels, Warren S.). The storm of July 18-19, 1952,

Rockford, Illinois, and vicinity: Ill. Water Survey Rept. Inv. 24, 14 p., 1955.

The report includes antecedent rainfall conditions, meteorological surface and upperair charts, records of rainfall at 53 stations, and streamflow data for 7 streams in the storm area.

LaRson, C. L.

(and Hermsmeier, L. F.). Device for measuring pipe effluent: Agr. Eng., v. 39, no. 5, p. 282-284, 1958.

The water level in a slotted tube mounted vertically at or near the end of a pipe is used as an index of discharge.

Larson, D. E. See Tobiaski, R. A.

Larson, Fred H.

(and Hall, G. Robert). The role of sedimentation in watersheds: Am. Soc. Civil Engineers Proc., v. 83, no. HY 3, Paper 1263, 14 p., 1957.

Program proposals may have widely divergent effects on sediment and floodwater damages. The approach to sediment problems being undertaken by the U.S. Department of Agriculture is outlined.

Larson, Thurston E. See also French, R. R.

1. (and Hettick, Irene). Mineral composition of rainwater: Ill. Water Survey Circ. 56, p. 191-201, 1956.

Analyses of 62 rainwater samples taken near Savoy, Ill., are given. Salt from sea mist constitutes a negligible proportion of the mineral content. Presence of air pollution by fuel combustion is indicated. 
2. (and Larson, B. O.). Quality of surface waters in Illinois: Ill. Water Survey Bull. 45, 135 p., 1957.

Data are given on water quality in 19 streams and 1 lake. Samples have been analyzed for 14 to 16 constituents in each. The significance and reliability of the sampling program and data are evaluated.

3. (and Larson, Bernt O.). Mineral quality of Illinois rivers: Am. Water Works Assoc. Jour., v. 49, no. 9, p. 1213-1222, 1957.

Quality data are presented as distribution curves. In general there was little or no relation between watershed area and variability in water quality.

Larson, W. E. See Bertoni, J.

Lassen, Leon. See Veihmeyer, F. J., 1.

Latta, Bruce F.

Public and industrial ground-water supplies of the Roanoke-Salem District, Virginia: Va. Div. Geology Bull. 69, 53 p., 1956.

Lau, Leung-Ku. See Todd, D. K., 4.

Lauderdale, Robert A. See Eliassen, R.

Lauff, George H.

Some aspects of the physical limnology of Grand Traverse Bay: Mich. Univ. Inst. Great Lakes Research Pub., no. 2, 56 p., 1957.

Observations and samples obtained on a 2-day survey of the Bay are described.

Lauritzen, Cyril W. See also Robinson, A. R., Jr., 2.

(and Haws, Frank W., and Humpherys, Allan S.). Plastic film for controlling seepage losses in farm reservoirs: Utah State Agr. Coll. Bull. 391, 18 p., July 1956.

During the past 2 years, polyethylene, vinyl, and other plastic films have been tested to determine resistance to weathering and other factors which influence durability of these films as linings for farm reservoirs.

Laursen, Emmetт M. See also Kindsvater, C. E., 1; Neville, J. F.; Schroeder, K. B. 1. The total sediment load of streams: Am. Soc. Civil Engineers Proc., v. 84, no. HY 1, Paper 1530, 36 p., 1958.

Proposed relationships give the quantity and quality of the total, suspended, and bedloads as functions of the stream and sediment characteristics. A correlation of laboratory and field data was obtained. (Discussions by R. J. Garde and M. L. Albertson, D. C. Bondurant, John L. Bogardi, v. 84, no. HY 6, Paper 1856, p. 59-79, 1958; and author's closure, v. 85, no. HY 3, Paper 1989, p. 51-52, 1959.)

2. Sediment-transport mechanics in stable-channel design: Am. Soc. Civil Engineers Trans., v. 123, p. 195-203, 1958.

Three requisites for a stable alluvial channel are given, the similarity of many sediment-transport formulas is demonstrated, and the general method of applying formulas to design is illustrated. (Discussion by Sam Shulits.)

Laverty, Finley B.

1. (and van der Goot, Herbert A.). Development of a fresh-water barrier in southern California for the prevention of sea water intrusion: Am. Water Works Assoc. Jour., v. 47, no. 9, p. 886-908, 1955.

Construction and operation of a recharge system are described.

2. Recharging ground water with reclaimed sewage effluent: Civil Eng., v. 28, p. 49-51, Aug. 1958. 
Tests show the practicability of water spreading and injection through wells of treated sewage effluent. Purpose is to prevent salt-water intrusion in the aquifers.

Law, William P., JR.

(and Renfro, George M., Jr.). Water is where the irrigator finds it, in U.S. Department of Agriculture, Water: Yearbook of Agriculture 1955, p. 333-340.

Streamflow with or without storage, natural lakes, or ground water may be used in Eastern United States. Methods of defining the usable supply are described.

Lawhon, Lester F. See Haise, H. R., 2; Quackenbush, T. H.

LAWLOR, WALTER F.

Flood control in the middle Mississippi: Am. Soc. Civil Engineers Proc., v. 81, Paper 803, 9 p., 1955.

The problem is described, and the means of protection are suggested. (Discussion by E. Kuiper, v. 82, no. WW 1, Paper 913, p. 15, 1956; and author's closure, v. 82, no. WW 4, Paper 1068, p. 7, 1956.)

Lawton, F. L. See Jaeger, C.

Lazard, Achille. See Escoffier, F. F., 1.

League of Women Voters of the United States.

On the water front: Washington League Women Voters United States Pub., no. 242, 20 p., 1957.

A nontechnical description of water problems is given.

Lee, Charles H. See Baumann, P.

LEE, K. Y.

1. Geology and shallow-water resources of the Blue Blanket Valley and Hoven Outwash, Potter County, South Dakota: S. Dak. Geol. Survey Rept. Inv., no. 80,57 p., 1956.

2. Geology and shallow-water resources between Hoven and Bowdle, South Dakota: S. Dak. Geol. Survey Rept. Inv. 83, 58 p., 1957.

3. Geology and shallow-ground-water resources of the Brookings area, Brookings County, South Dakota: S. Dak. Geol. Survey Rept. Inv. 84, 62 p., 1958.

Surficial deposits comprise chiefly drift of three subdivisions of the Wisconsin. During 1957 about 364,000 acre-feet of ground water was stored in outwash deposits of sand and gravel. The quality of the water is generally satisfactory for human consumption.

LEGGAT, E. R.

1. Geology and ground-water resources of Lamb County, Texas: Texas Board of Water Engineers Bull. 5704, 181 p., 1957.

2. Geology and ground-water resources of Tarrant County, Texas: Texas Board of Water Engineers Bull. 5709, 181 p., 1957.

Legget, R. F. See Crawford, C. B.

LEGGETTE, R. M.

Modern methods of developing ground-water supplies: Am. Soc. Civil Engineers Proc., v. 81, Separate 627, 9 p., 1955.

Methods and procedures used in developing ground-water resources are discussed. Suggestions for desirable observation and maintenance programs after development are given.

LeGrand, H. E. See also Fish, R. E.

1. Brackish water and its structural implications in Great Carolina Ridge, North 
Carolina: Am. Assoc. Petroleum Geologists Bull., v. 39, no. 10, p. 2020-2037, 1955.

The finding of surficial brackish water in Bladen County, N.C., led to a study of the Great Carolina Ridge.

2. (and Furcron, A. S.). Geology and ground-water resources of central-east Georgia, with a chapter on the surface-water resources by R. F. Carter and A. C. Lendo: Ga. Dept. Mines, Mining, and Geology Bull., no. 64, 174 p., 1956.

The geology and distribution of important minerals and rocks are discussed. A major part of the report concerns water resources.

3. Ground-water resources in North Carolina: N.C. Div. Mineral Resources Bull., no. 69, 20 p., 1956.

A popular account is given.

4. Chemical character of water in the igneous and metamorphic rocks of North

Carolina: Econ. Geology, v. 53, no. 2, p. 178-189, 1958.

Two normal types of ground water occur. One, associated with felsic rocks, is characterized by low concentrations of dissolved solids, low hardness, $\mathrm{pH}$ less than 7 , about equal amounts of sodium and calcium, and a considerable percentage of silica. The other is associated with mafic rocks and is characterized by a higher concentration of dissolved solids, greater hardness, $\mathrm{pH}$ greater than 7 , a greater amount of calcium than sodium, and a comparable content of silica.

Lehane, J. J. See Staple, W. J.

Leliavsky, Serge. See Lane, E. W., 2; Mostafa, M. G.

Lemmon, Paul E. See also Ingebo, P. A.

A spherical densiometer for estimating forest overstory density: Forest Sci., v. 2, no. 4, p. 314-320, 1956.

The report describes an instrument to make measurements of overstory density easily and accurately.

LEMON, E. R.

1. The potentialities for decreasing soil moisture evaporation loss: Soil Sci. Soc. America Proc., v. 20, no. 1, p. 120-125, 1956.

Mechanisms of soil moisture evaporation and methods for reducing the evaporation rate are described.

2. (and Glaser, A. H., and Satterwhite, L. E.). Some aspects of the relationship of soil, plant, and meteorological factors to evapotranspiration: Soil Sci. Soc. America Proc., v. 21, no. 5, p. 464-468, 1957.

Examples are given of the effects of soil, plant, and meteorological factors on measured evapotranspiration. Attempts to predict evapotranspiration without considering all three factors will not be completely successful.

Lendo, A. C. See LeGrand, H. E., 2.

Lenz, Arno T. See Zoller, J. H.

Leonard, Alvin R. See Fishel, V. C., 1.

Leopold, Luna B. See also Wolman, M. G., 1.

1. (and Miller, John P.). Ephemeral streams--hydraulic factors and their relation to the drainage net: U.S. Geol. Survey Prof. Paper 282-A, p. 1-37, 1956.

Measured hydraulic factors in conjunction with an analysis of drainage-basin configuration are used to determine the generalized interrelation of stream order and hydraulic variables. 
2. Water and the conservation movement: U.S. Geol. Survey Circ. 402, 12 p., 1958.

Two addresses on water problems are given.

LeRoux, E. F.

Geology and ground-water resources of Outagamie County, Wisconsin: U.S.

Geol. Survey Water-Supply Paper 1421, 57 p., 1957.

This report includes a discussion of the geology of the area, the occurrence of ground water, the hydrologic properties of the aquifers, and the chemical quality of the water.

Lester, R. I. See Roark, C. L.

Leutze, Willard P. See Wyrick, G. G.

Leve, Gilbert W.

Interim report on the ground-water resources of Putnam County, Florida: Fla.

Geol. Survey Inf. Circ., no. 15, 33 p., 1958.

Ground water occurs under both artesian and nonartesian conditions; chloride content is variable.

Levine, Gilbert. See Bouwer, H.

Lewis, G. C. See Jordan, J. V.

LI, Huon. See Einstein, H. A., 4.

Li, Shu-T'Ien. See Kolb, C. R.

Li, Wen-Hsiung. See also Petersen, J. S.

1. Open channels with nonuniform discharge: Am. Soc. Civil Engineers Trans., v. 120 , p. 255-274, 1955.

An equation based on the principle of conservation of momentum is derived. For cases in which the loss of energy because of friction is of secondary importance, solutions are obtained for prismatic channels. The hydraulic behavior of flow is described, and the validity of the theory verified. (Discussion by Turgut Sarpkaya.)

2. (and Patterson, Calvin C.). Free outlets and self-priming action of culverts: Am. Soc. Civil Engineers Proc., v. 82, no. HY 3, Paper 1009, 22 p., 1956.

Data on the effective position of the hydraulic gradeline at the free outlet of fullflowing culverts and on the conditions for self-priming of culverts with a sharpcornered entrance are presented. (Discussions by Fred W. Blaisdell, v. 82, no. HY 6, Paper 1131, p. 5-8, 1956; J. E. Flack, John L. French, v. 83, no. HY 1, Paper 1177, p. 23-40, 1957; and authors' closure, v. 83, no. HY 4, Paper 1348, p. $3-5,1957$.

LichtLeR, W. F.

Ground-water resources of the Stuart area, Martin County, Florida: Fla. Geol. Survey Inf. Circ., no. 12, 47 p., 1957.

The principal source of ground-water supplies, a shallow nonartesian aquifer, is described in detail.

Lieblein, Julius. See Krumbein, W. C.

LigDA, M. G. H.

The use of radar in severe storm detection, hydrology, and climatology; final report on contract CWB 8716: Texas A. and M. Research Found., Oct. 1956.

Lillard, J. H. See Burford, J. B.; van Bavel, C. H. M., 6. 
Lin, Pin-Nam. See Brooks, N. H.; Kindsvater, C. E., 1.

Lincoln, Russelu L. See Decker, F. W.

Lindh, C. OтTo.

Watershed management on the national forests of the South: Soc. Am. Foresters Proc., p. 113-115, 1956.

A general description is given.

Lindsay, C. V. See Harris, D. L., 3.

Linehan, Daniel.

The geohydrology of New England: New England Water Works Assoc. Jour., v. 72 , no. 2, p. 149-159, 1958.

A general description of geohydrology is given.

Linsley, Ray K., JR. See also Rowe, R. R.

1. (and Franzini, Joseph B.). Elements of hydraulic engineering: New York, McGraw-Hill Book Co., 582 p., 1955.

Hydraulic engineering is dealt with as a unified field; first the fundamentals common to all fields are discussed, then the special aspects of each field are reviewed. Part I deals with the hydrologic and legal aspects common to almost all hydraulic projects. Part II discusses the structures required for hydraulic projects, and Part III the special problems found in this field.

2. Correlation of rainfall intensity and topography in Northern California: Am. Geophys. Union Trans., v. 39, p. 15-18, 1958.

The 2-year, 1-hour rainfall intensity is related to topographic and climatic parameters. This relation permits intensity to be shown in greater detail than would be possible from observed data. (Discussion by W. T. Wilson and D. M. Hershfield, v. 39, p. 970-972, 1958.)

3. (and Kohler, Max A., and Paulhus, Joseph L. H.). Hydrology for engineers: New York, McGraw-Hill Book Co., 340 p., 1958.

This book provides a sound theoretical background in hydrology and at the same time emphasizes practical, well-tested methods for the application of hydrology in engineering. Techniques are stressed which utilize correlation methods and eliminate judgment to the maximum possible extent. Many problems and references are included.

Littleton, R. T. See also Rapp, J. R.

(and Crosthwaite, E. G.). Ground-water geology of the Bruneau-Grand View area,

Owyhee County, Idaho: U.S. Geol. Survey Water-Supply Paper 1460-D, p. 147-198, 1957.

Geologic factors that affect the ground-water supply are emphasized. A preliminary, qualitative appraisal of the ground-water resources of the area is given.

Liu, Hsin-Kuan. See also Brooks, N. H.; Carey, W. C.; Chien, N., 1; Mostafa, M. G.

1. Mechanics of sediment-ripple formation: Am. Soc. Civil Engineers Proc., v. 83, no. HY 2, Paper 1197, 23 p., 1957.

The literature is reviewed, and the primary cause of ripple formation is described. An experimental criterion is given to predict the formation of sediment ripples and d unes. (Discussions by Thomas Maddock, Jr., v. 83, no. HY 5, Paper 1417, p. 9-11, 1957; Vito A. Vanoni and Norman H. Brooks, E. Roy Tinney, M. L. Albertson and D. B. Simons and E. V. Richardson, v. 84, no. HY 1, Paper 1558, p. 17-32, 1958; John L. Bogardi; and author's closure, v. 84, no. HY 5, Paper 1832, p. 3-31, 1958. Corrections to discussion by Bogardi and to author's closure, v. 84, no. HY 7, Paper 1880, p. 3-4, 1958.) 
2. (and Bradley, J. N., and Plate, E. J.). Backwater effects of piers and abutments: Colo. State Univ. Dept. Civil Eng., 364 p., 1957.

This is a report on a study of backwater effects and related problems for clear water flowing through a constriction caused by bridge abutments with or without piers in an open channel with a rigid boundary. Results are given for a variety of bridge crossing conditions.

3. A note on the differential equation of steady, gradually non-uniform flow in open channels: Am. Geophys. Union Trans., v. 39, p. 939-940, 1958.

This note is intended to clarify a sign convention. (Discussion by Ven Te Chow, Jour. Geophys. Research, v. 64, p. 487-488, 1959; and author's reply, Jour. Geophys. Research, v. 64, p. 1346, 1959.)

Livesey, Robert H. See also McCain, E. H.

Reconnaissance report, deposition in Ft. Randall Reservoir, Missouri River, South Dakota: U.S. Army Corps Engineers, Missouri River Div., Sediment Memo., no. 5, 12 p., Sept. 1955.

Lockett, W. G. See Jaeger, C.

Loehnberg, Alfred.

1. Water supply and drainage in semi-arid countries: Am. Geophys. Union Trans., v. 38, p. 501-510, 1957.

Drainage cannot be separated from water supply for land development in hill-plain border regions. A total inventory of surface and subsurface waters is required. Methods of development are described. (Discussion by Raphael G. Kazmann; and author's closure, v. 39, p. $736-737,1958$.)

2. Aspects of the sinking of Mexico City and proposed countermeasures: Am. Water Works Assoc. Jour., v. 50, no. 3, p. 432-440, 1958.

The sinking resulted from removal of ground water. Artificial positive groundwater levels obtained by recharge are proposed as a solution.

LoHr, E. W.

Chemical character of public water supplies of the larger cities of Alaska, Hawaii, and Puerto Rico, 1954: U.S. Geol. Survey Water-Supply Paper 1460-A, p. 1-39, 1957.

The data consist of the population (1950) of the selected cities, the population served, ownership source and treatment of supplies, capacity of treatment plants, storage facilities, and channel analyses of the water.

LoNG, A. T.

Ground-water geology of Real County, Texas: Texas Board Water Engineers Bull. 5803, 46 p., 1958.

Long, Gordon L. See Rowe, R. R.

Long, L. W.

(and Conner, N. W.). Tests on a broad-crested weir with two different surface adhesion conditions: N.C. State Coll. Dept. Eng. Research Bull., no. 61, 26 p., 1956.

Measurements of the coefficient of discharge in 6- and 41/2-inch channels with clear glass and paraffin-coated surfaces were made.

Long, William A.

What's happening to our glaciers: Sci. Monthly, v. 81, no. 2, p. 57-64, 1955.

The glaciers of Washington State are described and information on changes in their terminal positions is given. 
LORENz, H. W.

(and McMurtrey, R. G.). Geology and occurrence of ground water in the Townsend valley, Montana, with a section on chemical quality of the ground water, by H. A. Swenson: U.S. Geol. Survey Water-Supply Paper 1360-C, p. 171-290, 1956.

The geography, geology, and ground-water characteristics are described. Some of the land is waterlogged. Water generally is hard but only moderately mineralized.

Louisiana Department of Public Works.

Water: La. Dept. Public Works Spec. Rept. to the La. Legislature, 56 p., 1956. This paper discusses the occurrence, use, developments, investigations, and problems of surface and ground waters on a statewide basis.

\section{Louisiana Engineering Experiment Station.}

1. Proceedings of the 4th annual Water Symposium, March 22-23, 1955: La. Eng. Expt. Sta. Bull., no. 51, 118 p., 1955.

The report includes papers on water-resources developments, water-quality standards, utilization of ground water, role of surface waters, pollution, salt-water disposal, and water problems.

2. Proceedings of the 5th annual Water Symposium, Feb. 21-22, 1956: La. State Univ. Eng. Expt. Sta. Bull., no. 55, 116 p., 1956.

The report contains papers on artificial rainmaking, water resources of the South, and several on waste treatment.

3. Proceedings of the 6th annual Water Symposium, Feb. 19-20, 1957: La. Eng. Expt. Sta. Bull., no. 59, 75 p., 1957.

Seven papers generally relating to waste disposal and pollution control are presented.

Louisiana Legislative Council.

Water problems in the Southeastern States: La. Legislative Council Research Study No. 11, 110 p., 1955.

This is a revision of Research Study No. 5. It is a factual presentation with respect to water problems.

Love, Claude L.

(and Singewald, Joseph T., Jr., Groot, John J., and Pendleton, Wendell). Water law in Eastern United States: Am. Water Works Assoc. Jour., v. 49, no. 6, p. 721-742, 1957.

A symposium describing water law in North Carolina and other Atlantic States, Maryland, Delaware, and Iowa.

Love, L. D. See also Garstka, W. U., 2; Renner, F. G.

1. (and Renner, F. G.). Management of water on western rangelands, in U.S. Department of Agriculture, Water: Yearbook of Agriculture 1955, p. 415-423.

The importance of holding rain where it falls for the growth of forage plants for livestock is discussed; also the report summarizes some of the supplemental measures which might be applied to rangelands to increase water absorption and forage production.

2. The effect on stream flow of the killing of spruce and pine by the Engelmann spruce beetle: Am. Geophys. Union Trans., v. 36, p. 113-118, 1955.

Analyses show an increase in streamflow after the killing of the mature spruce and pine had been completed. (Discussions by Conrad D. Bue, and Milton T. Wilson and Eugene L. Peck, v. 36, p. 1087-1089, 1955.) 
3. High dams and upstream storage. Part 1B. Can watershed management alleviate the need for large storage projects?: Mont. State Univ. 2d Ann. Water Resources Conf. Proc., 1957, p. 14-21, 1958.

The results of forest, range, and watershed research in the central Rockies of Colorado are outlined. The report points out how these activities supplement the need for large storage projects. The extent to which the streamflow hydrograph is altered by watershed management activities dictates the size of the projects.

4. Rangeland watershed management: Soc. Am. Foresters Proc., p. 198-200, 1958.

Some of the concepts are pointed out.

Love, S. K. See Parker, G. G., 2.

Lowry, Gerald L.

Estimating permanent wilting point in the field by a direct laboratory calibration: Soil Sci. Soc. America Proc., v. 22, no. 2, p. 95-98, 1958.

A method is described whereby soils may be calibrated with fiberglass soil moisture units at 15 atmospheres tension using the pressure membrane apparatus. Resistance readings are related to the wilting range.

LowRy, WILLIAM P.

Evaporation from forest soils near Donner Summit, California, and a proposed field method for estimating evaporation: Ecology, v. 37, p. 419-430, 1956.

Two standard field methods for estimating evaporation rates based on the vapor pressure deficit concept are reviewed and applied to data. Reliability of the methods compares well with that found by other investigations.

LUCas, Henry F., JR.

(and Ilcewicz, Frank H.). Natural radium 226 content of Illinois water supplies:

Am. Water Works Assoc. Jour., v. 50, no. 11, p. 1523-1532, 1958.

Concentration was measured in samples from 159 municipal supply sources.

Ludzack, F. J. See also Straub, C. P.

1. (and Ettinger, M. B.). Biological oxidation of hexadecanol under laboratory conditions: Am. Water Works Assoc. Jour., v. 49, no. 7, p 849-858, 1957.

Biological destruction of a hexadecanol monolayer is large enough to be considered in economies of use for suppressing evaporation.

2. (and Ingram, William Marcus, and Ettinger, M. B.). Characteristics of a stream composed of oil refinery and activated sludge effluents: Sewage and Indus. Wastes, v. 29, no. 10, p. 1177-1189, 1957.

Conditions on Ottawa River, Ohio, are described.

Lueck, B. F. See also Scott, R. H.

(and Wiley, A. J., Scott, Ralph H., and Wisniewski, T. F.). Determination of stream purification capacity: Sewage and Indus. Wastes, v. 29, no. 9, p. 1054$1065,1957$.

A generalized definition for stream purification capacity is proposed. The effects of temperature and rate of reaction are discussed.

Lull, How ard W. See also Pierce, R. S., 2; Reigner, I. C., 1; Trimble, G. R., Jr., 2; Tripp, N. R.; Veihmeyer, F. J., 1.

1. Water supplies and our forests: Pa. Forests, v. 45, p. 58-60, 1955.

Problems of demand and supply and the need for forest watershed management research are given.

2. (and Reinhart, K. G.). Soil-moisture measurement: U.S. Forest Service, Southern Forest Expt. Sta. Occasional Paper 140, 56 p., 1955. 
The report reviews the various methods of measuring soil moisture and evaluates those used currently. It also describes a study carried on by the Vicksburg Infiltration Project to determine variations in amount of soil moisture at several sites. 3. (and Marquis, Ralph W.). Forests guard the Potomac: Interstate Comm. Potomac River Basin, 19 p., 1957.

The effects of forests on streamflow, with reference to Potomac Basin are discussed. 4. (and Storey, Herbert C.). Factors influencing streamflow from two watersheds in northeaštern Pennsylvania: Jour. Forestry, v. 55, p. 198-200, Mar. 1957.

The difference in variability of flow from two gaged watersheds is shown and is explained in terms of the differing land use and soil types.

5. (and Reigner, Irvin C.). A program of watershed-management research on forest lands in the upper Delaware and Susquehanna River Basins: U.S. Forest Service, Northeastern Forest Expt. Sta. Paper 92, 33 p., 1957.

Forest and water resources, problems by regions, and a proposed research program are discussed.

6. Forest watershed management research in Pennsylvania: Pa. Forests, v. 37, p. $41-42,1957$.

Development and results of research are given.

7. What they said about forests and floods in Pennsylvania 50 to 75 years ago: Pa. Forests, v. 37, p. 91-92, 107, 1957.

This is a survey of early literature.

8. Municipal watersheds in the Northeast: Am. Water Works Assoc. Jour., v. 50, no. 7 , p. $979-982,1958$.

A survey of the size and location of watersheds and the problems of forest and water management are presented.

9. (and Axley, John H.). Forest soil-moisture relations in the Coastal Plain sands of southern New Jersey: Forest Sci., v. 4, no. 1, p. 2-19, 1958.

Soil moisture measurements during the growing season on upland sites indicated that stands of shortleaf pine and scrub oak used about the same amount of water at about the same rate from the upper 5 feet of soil. Evapotranspiration for a 7 -month period was 26.2 inches from a pine-pole plot. Of this, 20.8 inches came from depths less than 5 feet.

10. Better water through forest management; in Better water through forestry and engineering: Interstate Comm. Potomac River Basin, p. 10-19, 1958.

Adequacy of forest protection in Potomac Basin, management program, and research needs are discussed.

11. (and Tripp, Norman R.). The management of forested watersheds in New England: New England Water Works Assoc. Jour., v. 72, no. 4, p. 341-349, 1958.

The effects of forests on water yield and quality are discussed, and tentative recommendations for management are suggested.

Lunetta, Anthony M.

Flood plain aspects of river planning: Am. Soc. Civil Engineers Proc., v. 82, no. HY 4, Paper 1040, 7 p., 1956.

Flood-plain regulations must be based on an examination of the hydraulic, hydrologic, economic, and social aspects of the problem. (Discussion by Robert L. Smith, v. 82, no. HY 4, Paper 1041, p. 31-33, 1956.)

Lunin, J.

(and Gallatin, M. H.). Brackish water for supplemental irrigation: Soil Conserv., v. 23 , no. 6 , p. 117-119, 1958.

Six factors must be considered in determining the feasibility of using brackish water. 
Luthin, James N. See also Burgy, R. H., 1; Day, P. R., 2; Zee, C. H. (and Day, Paul R.). Lateral flow above a sloping water table: Soil Sei. Soc. America Proc., v. 19, no. 4, p. 406-410, 1955.

Lateral movement of water above a water table has been studied under steady-state conditions. Experimental results agree with the solution of the nonlinear Laplace equation.

MaAsland, M. See Werner, P. W.

McAleer, John B.

(and Townsend, George E.). Hurricane protection planning in New England:

Am. Soc. Civil Engineers Proc., v. 84, no. HY 4, Paper 1726, 36 p., 1958.

Basic data and engineering methods used in a hurricane survey of New England are given.

McAvor, R. L.

(and Harris, K. F.). Chemical and physical character of surface waters of North Carolina, 1954-55: N.C. Div. Water Resources, Inlets, and Coastal Waterways Bull. 52, v. 11, 120 p., 1956.

Factors which influence the quality of surface waters are described. Chemical analyses and water temperatures are presented graphically and in tables.

McCaIG, I. W. See Jaeger, C.

McCaIn, E. H.

Measurement of sedimentation in TVA reservoirs: Am. Soc. Civil Engineers Proc., v. 83, no. HY 3, Paper 1277, 12 p., 1957.

Equipment assembled or developed by the TVA for sediment investigations is described. (Discussion by Lloyd C. Fowler and Robert H. Livesey, v. 83, no. HY 5, Paper 1417, p. 37-46, 1957.)

McCallum, G. E. See Hollis, M. D.

McCarren, Edward F. See Rasmussen, W. C., 2.

MacCary, L. M. See Pree, H. L.

MacCready, Paul B., Jr. See Todd, C. J.

McCullough, Charles A. See Willets, D. B.

McCune, Donald L. See Meyer, L. D.

McCutchan, Arthur I. See Carlson, E. J.

McDermotr, R. E. See Fletcher, P. W.

McDonald, Harris R.

Irrigation aspects (in Ground water development-a symposium): Am. Soc. Civil Engineers Trans., v. 122, p. 443-457, 1957.

The advantages of ground-water pumping to reduce losses, to prevent and reduce drainage problems, and to irrigate additional lands are cited.

McDonald, James E.

1. Variability of precipitation in an arid region; a survey of characteristics for Arizona: Ariz. Univ. Inst. of Atmospheric Physies Tech. Repts. Meteorology and Climatology Arid Regions, no. 1, 88 p., 1956.

2. A note on the precision of estimation of missing precipitation data: Am. Geophys. Union Trans., v. 38, p. 657-661, 1957.

Errors of 25 percent must be expected in seasonal totals estimated from two index stations. 
3. A critical evaluation of correlation methods in climatology and hydrology: Ariz. Univ. Inst. Atmospheric Physics, Sci. Rept., no. 4, 36 p., 1957.

The author suggests that because of nonnormality of data, the simpler significance tests are as good as the more rigorous ones. For nonnormal data he proposes use of Spearman's rank correlation coefficient instead of the product-moment correlation coefficient.

McDodgald, J. M. See Wilcox, J. C.

McFarland, John W. See Morris, S. B., 1.

McGauhey, P. H. See also Krone, R. B.

1. Theory of sedimentation: Am. Water Works Assoc. Jour., v. 48, no. 4, p. 437$448,1956$.

This paper gives the origins and relationships of the laws of sedimentation commonly reported in engineering literature.

2. (and Erlich, Harry). Economic evaluation of water, Part 1, A search for criteria: Calif. Univ. Water Resources Center Contr., no. 13, 237 p., 1957.

A search for broad economic criteria by which the economic good of alternate beneficial uses of water may be judged.

McGuinness, C. L. See Kazmann, R. G., 1.

McGuinness, J. L. See Potter, W. D., 1.

McIntosh, RoBert P.

Fog drip, an anticipation of ecology: Ecology, v. 39, p. 159, 1958.

Two quotations describing precipitation from fog drip under trees are given.

Mack, Leshie E.

Evaluation of a conducting-paper analog field plotter as an aid in solving groundwater problems: Kans. Geol. Survey Bull. 127, pt. 2, 47 p., 1957.

A potentiometric model, which utilizes the analogy between fluid flow and electriccurrent conduction, may be used to obtain rapid solutions to complex twodimensional ground-water flow problems. The model (plotter) cannot be applied accurately to any three-dimensional steady-state ground-water flow problems.

MACK, Sermodr.

Geology and ground-water features of Scott Valley, Siskiyou County, California:

U.S. Geol. Survey Water-Supply Paper 1462, 98 p., 1958.

This report describes the water-bearing deposits, the relation of geology to the occurrence of ground water, and the chemical character of the water. An estimate of the ground-water storage capacity of the area is made.

McKean, Roland N.

Efficiency in government through system analysis: New York, John Wiley and Sons, 336 p., 1958.

This presentation, which emphasizes water resources development, is meant to be suitable for cost-benefit analysts, operations researchers, government personnel and those in academic circles who are interested in evaluating alternative courses of action, and persons in general who are concerned about economy in government.

MacKichan, Kenneth A.

1. Estimated use of water in the United States: Am. Water Works Assoc. Jour., v. 49 , no. 4 , p. $369-391,1957$. 
This report presents an estimate of the quantity of water withdrawn during 1955 from ground and surface sources.

2. Estimated use of water in the United States, 1955: U.S. Geol. Survey Circ. 398, 18 p., 1957.

Withdrawal use of water is estimated for five types of use.

McLaughlin, Thad G.

1. Geology and ground-water resources of Baca County, Colorado: U.S. Geol. Survey Water-Supply Paper 1256, 232 p., 1954 [1955].

This report describes the geology particularly as it affects the ground-water aquifers. Depths to the water table, sources of recharge to the aquifers, and direction of movement of the ground water are given.

2. Hydrologic aspects of ground water law: Am. Water Works Assoc. Jour., v. 47, no. 5 , p. $447-452,1955$.

The difficulties encountered in classifying water for legal purposes are discussed.

MacLeman, Everett L.

Yield of impounding reservoirs: Water and Sewage Works, v. 105, no. 4, p. 144-149, 1958.

Several approaches to the problem of determining the safe yield of impounded water supplies, and examples of each, are given.

McLeod, KeIth T.

Weather modification in Canada: Eastern Snow Conf. Proc., p. 64-73, 1958.

History of cloud seeding in Canada is discussed. The effectiveness has not been established.

McMurtrey, R. G. See Lorenz, H. W.

McNall, Dorothy R. See Nichols, M. S.

McNamara, E. F. See Reigner, I. C., 1, 2.

McNaughton, A. G. L.

Problems of development of international rivers: Eng. Jour., v. 39, no. 11, p. 1493$1503,1956$.

The jurisdictional, topographical, and hydrological conditions and problems at issue in the Pacific watershed of Canada and the United States are indicated. The solution proposed in the Canadian portion of the basin of the Columbia is described as an example. (Author's supplement, v. 39, no. 12, p. 1692, 1956.)

MacNaughton, Victor B. See Heard, W. L.

McNiesh, R. J. See Jenkins, D. S., 1.

McPherson, M. B. See Keifer, C. J.; Stevens, J. C.

MaQueen, I. S. See Nace, R. L., 2.

MoQurukIn, W. E. See Reigner, I. C., 1.

Maddock, Thomas, Jr. See Liu, H. K., 1.

Maffitt, Dale L.

Missouri River basin development: Am. Water Works Assoc. Jour., v. 47, no. 5, p. 419-425, 1955.

A general description is given.

Malm, Donald E. G. See Chorley, R. J. 
Malmberg, Glenn T.

(and Downing, H. T.). Geology and ground-water resources of Madison County, Alabama: Ala. Geol. Survey County Rept. 3, 225 p., 1957.

This is a report of an investigation to study the relations of the occurrence, quality, and availability of ground water to the geology of Madison County.

Maloney, Frank E.

Laws of Florida governing water use: Am. Water Works Assoc. Jour., v. 47, no. 5, p. 440-446, 1955.

Legal decisions related to the use of surface and ground water and suggestions for legislation are given.

Maner, Sam B.

Factors affecting sediment delivery rates in the Red Hills physiographic area: Am. Geophys. Union Trans., v. 39, p. 669-675, 1958.

Relief and maximum length of watershed are more closely correlated with sedimentdelivery rates than size of sediment-contributing area.

MaNn, John F., JR.

Primary water: Water Well Jour., v. 9, no. 3, 1955.

Some water does originate deep in the earth, but it is not much good for anything.

Manohar, Madhav. See also Stevens, J. C.

Mechanics of bottom sediment movement due to wave action: U.S. Beach Erosion Board Tech. Memo., no. 75, 121 p., 1955.

Results are presented from an analytical and experimental investigation of motion of sediment, induced by action of surface waves, in relatively deep water.

Manson, Philip W.

(and Miller, Dalton G.). Ground water fluctuations in certain open and forested bogs of northern Minnesota: Minn. Agr. Expt. Sta. Bull. 217, 28 p., 1955.

Mansur, Charles I.

1. (and Kaufman, Robert I.). Underseepage, Mississippi River levees, St. Louis

District: Am. Soc. Civil Engineers Trans., v. 122, p. 985-1008, 1957.

This paper describes the underseepage problem and the procedures used to design seepage control measures.

2. Laboratory and in-situ permeability of sand: Am. Soc. Civil Engineers Trans., v. 123, p. $868-882,1958$.

Results of laboratory tests on remolded sand samples are compared with permeabilities obtained from field pumping tests. Laboratory tests did not give reliable permeability coefficients.

Marine, Ira Wendell.

(and Rasmussen, William Charles). Preliminary report on the geology and groundwater resources of Delaware: Del. Geol. Survey Bull., no. 4, 336 p., 1955.

This report is concerned primarily with the occurrence, quantity, and quality of ground water. Its purpose is to acquaint the people of Delaware with the water resources of their State. Geology and hydrology of both large and small areas are discussed.

Mark, Frederick A.

Meeting Washington's small watersheds problems: Jour. Soil and Water Conserv., v. 13 , no. 6 , p. $259-268,1958$.

A detailed description of the problems in eastern and in western Washington is given. 
Marquis, RalPh W. See Lull, H. W., 3.

Marriage, Lowell D. See Burt, W. B.

MARrIS, A. W.

Fluid turbulence and suspended sediment: Canadian Jour. Technology, v. 33, no. 6 , p. $470-493,1955$.

A derivation is given of a formula for concentration of fine sediment for a stream of infinite width flowing turbulently over a smooth bed.

Marsell, R. E. See Eardley, A. J.

Marsh, Albert W. See Abd-El-Samie, A. G.

Marston, Richard B. See also Veihmeyer, F. J., 1.

1. Infiltration rates of two waterspreading projects, Davis County, Utah: U.S. Forest Service Intermountain Forest and Range Expt. Sta. Research Note 25, 5 p., 1955.

The report describes two kinds of waterspreading projects and presents data on the total amount of water handled by each project as well as the maximum rates of infiltration.

2. Is the world's rainiest rain forest in southern Davis County, Utah?: Utah Acad. Sci., Arts, and Letters, 1955.

Maximum rates of infiltration of water in an oakbrush patch in Utah are compared with rates reported for a water-spreading project at Seabrook Farms, N.J.

3. The Davis County Experimental Watershed story: U.S. Forest Service, Intermountain Forest and Range Expt. Sta. Brochure, 39 p., 1958.

The report sketches flood history of the area and explains significance of successful flood-control measures.

4. Parrish Canyon, Utah; a lesson in flood sources: Jour. Soil and Water Conserv., v. 13, no. 4, p. 165-167, 1958.

Results are given of the effect of restoring vegetal cover in a basin that produced four severe mud-rock floods in 1930 .

5. Use of a nuclear soil moisture meter in studies of evapotranspiration on mountain soils: Soc. Am. Foresters Proc., p. 39-41, 1958.

Measurements made with the meter are of an exploratory nature.

Martin, Robert O. R. See Dingman, R. J., 2; Rasmussen, W. C., 2.

Martin, Roscoe C. See Duke University School of Law.

Marx, George W.

Quality of Arizona municipal supplies: Am. Water Works Assoc. Jour., v. 47, no. 1, p. 65-70, 1955.

The fluoride content is emphasized.

Maryland Special Commission.

Water in Maryland: Spec. Comm. Study Water Resources Md., 50 p., 1956.

A preliminary report on the water resources problem in Maryland is given.

Mason, Arnold C. See Wentworth, C. K.

Mason, Betty J. See Fishel, V. C., 3.

Massachusetts.

Special commission on ground-water supplies in Bristol and Plymouth Counties;

Report, January 1955; Mass, Senate Doc, 620, 22 p., 1955, 
Mateer, C. C.

A preliminary estimate of the average insolation in Canada: Canadian Jour. Agr. Sci., v. 35, no. 6, p. 579-594, 1955.

Monthly charts are presented based on instrumental observations supplemented by estimates derived from empirical equations relating average insolation to average sunshine or cloudiness.

Matejka, Donald Q. See Benedict, P. C., 1.

Mather, John R. See Thornthwaite, C. W., 1, 2, 3, 4; Veihmeyer, F. J., 1.

Mathews, W. H.

Physical limnology and sedimentation in a glacial lake: Geol. Soc. America Bull., v. 67, p. 537-552, 1956.

A study of limnology and bottom sediment in Garibaldi Lake, British Columbia, indicates that the causes of overflows or underflows in the lake are related to temperature and sediment load of the meltwater streams. These streams provide most of the bottom sediment.

Matson, Howard O.

(and Heard, William L., Lamp, George E., and IIch, David M.). The possibilities of land treatment in flood prevention, in U.S. Department of Agriculture, Water: Yearbook of Agriculture 1955, p. 176-179.

Land treatment supplemented by small waterflow-retarding structures and streamchannel improvements can provide protection in the headwater areas from floods that occur once in 10 years or oftener.

Matthai, H. F.

1. Index of surface-water records to September 30, 1955, part 5, Hudson Bay and upper Mississippi River basins: U.S. Geol. Survey Circ. 385, 26 p., 1956.

An index giving drainage area and period of record is presented.

2. Index of surface-water records to September 30, 1955, part 6, Missouri River basin: U.S. Geol. Survey Circ. 386, 44 p., 1956.

An index giving drainage area and period of record is presented.

3. (and Back, William, Orth, R. P., and Brennan, Robert). Water resources of the San Francisco Bay area, California: U.S. Geol. Survey Circ. 378, 55 p., 1957.

This report summarizes data on availability and use of surface and underground waters.

Matthes, Gerard H.

River surveys in unmapped territory: Am. Soc. Civil Engineers Trans., v. 121, p. 739-752, 1956.

Shortcut methods adapted to exploratory surveys for estimating river discharge and river gradients and methods of providing reliable surveys of specific local areas are given. (Discussion by Frederic T. Mavis, T. H. F. Nevins, Chesley J. Posey, and Edward Kuiper.)

Matzke, Stan.

Drouth proves value of storage water: Jour. Soil and Water Conserv., v. 12, no. 3, p. 129-132, 1957.

The drought years of 1934 and 1936 are compared with recent ones to illustrate the value of stored water.

Mavis, Frederic T. See Matthes, G. H. 
Mayer, Harold M. See White, G. F., 2.

Mayhugh, M. S. See Gardner, W. R., 1.

Мech, Steven L. See Veihmeyer, F. J., 1.

MedLock, O. C.

Improved water-disposal systems: Better Crops with Plant Food, v. 38, no. 8, p. 13, Oct. 1955.

The report describes the development of improved water-disposal systems in which most of the terraces are parallel.

Meeк, John F. See Davis, K. C.

Meginnis, H. G.

1. Forestry and water resource development in the South: Forest Farmer, v. 16, no. 2 , p. $12-13,28-30,31-32,1956$.

The report discusses some water-supply needs and prospective regional developments in the South and how they may affect forestry enterprises there.

2. Principles of watershed management based on current research: Proc. of fall meeting of the Interstate Comm. Potomac River Basin, p. 15-19, 1956.

This is a review of accomplishments in watershed research, and principles and concepts developing out of it with particular reference to plant-soil-water relationships.

Megregian, Stephen. See Hartung, H. O., Palange, R. C.

MeIER, M. F.

(and Simons, W. D.). An application of snow survey data to glacier research:

Western Snow Conf. Proc., p. 59-62, Apr. 1957.

Special snow-survey techniques are needed. The objectives of glacier research are (1) an understanding of the hydrology and (2) the use of glaciers as indicators of climate.

Meigs, Peveril.

(and de Percin, Fernand). Frequency of cold-wet climatic conditions in the United

States: Monthly Weather Rev., v. 85, no. 2, p. 45-52, 1957.

Frequency maps of occurrence of cold-wet conditions by months for the contiguous United States are presented. A table of the same information for 61 stations is also included. Cold-wet condition is here defined by the Quartermaster Corps on a physicophysiological personal experience basis.

\section{Melton, Mark A.}

1. An analysis of the relations among elements of climate, surface properties, and geomorphology: Columbia Univ. Dept. Geology Tech. Rept., no. 11, 102 p., 1957.

The topographic texture and average valley side slopes are related to the causative and determinative factors of climate and lithology for 80 basins in Western United States.

2. List of sample parameters of quantitative properties of landforms; their use in determining the size of geomorphic experiments: Columbia Univ. Dept. Geology Tech. Rept., no. 16, 17 p., 1958.

List of sample sizes, means, variances, and coefficients of variation determined from measurements of various elements of landforms are given. These may be useful in experimental design.

3. Geometric properties of mature drainage systems and their representation in an E4 phase space: Jour. Geology, v. 66, no. 1, p. 35-54, 1958. 
Basin characteristics are described quantitatively.

Mermel, T. W.

Register of dams in the United States: New York, McGraw-Hill Book Co., 429 p., 1958.

The report includes data on all dams more than 50 feet in height, photographs of 300 dams, an index of reservoir names, and lists of the 100 highest dams, the 100 largest dams, and the 100 greatest reservoirs created by dams. This work was sponsored by the United States Committee of the International Commission on Large Dams.

Merriam, Carroll F. See also Langbein, W. B., 1.

Potential value of ground-water data: Am. Geophys. Union Trans., v. 37, p. 463467, 1956.

Potential value justifies cost of collecting data.

Merryfield, Fred.

Review of Oregon water law: Am. Water Works Assoc. Jour., v. 49, no. 8, p. 986-992, 1957.

Provisions of the law and activities of the Resources Board are given.

Metzger, D. G.

Geology and ground-water resources of the Harquahala Plains area, Maricopa and Yuma Counties, Arizona: Ariz. Land Dept. Water Resources Rept., no. 3, 40 p., 1957.

A reconnaissance study yielding qualitative results.

Metzler, Dwight F. See also Krause, K. S.

1. Effect of drought on Kansas water supply practice: Am. Soc. Civil Engineers Proc., v. 81, Paper 780, 14 p., 1955.

Problems of maintaining the bacterial and chemical quality of water after the severe rainfall deficiency of 1952-54 are discussed. Comments on the effect of drought on waterworks design are made.

2. Recommended action against effects of severe droughts in Kansas: Am. Water Works Assoc. Jour., v. 48, no. 8, p. 999-1004, 1956.

The causes of droughts are described. Future measures include hydrologic research, pollution abatement, increased degree of development, use of ground-water storage, and reduction of wastage.

3. Improvement of water quality in Kansas: Am. Water Works Assoc. Jour., v. 50, no. 9, p. 1180-1184, 1958.

Sewage treatment and oil brine pollution abatement have improved quality. Storage has reduced turbidity downstream. Chemical quality investigation of surface waters is continuing.

Meyer, H. Arthur. See Worley, D. P.

Meyer, H. I. See Hollingsworth, B. J.

Meyer, L. Donald.

(and McCune, Donald L.). Rainfall simulator for runoff plots: Agr. Eng., v. 39, no. 10 , p. $644-648,1958$.

The report describes a portable machine to provide simulated high-intensity rainstorms for test plots as an aid in erosion and runoff studies.

Meyer, R. R. See also Rasmussen, W. C., 1.

(and Turcan, A. N., Jr.). Geology and ground-water resources of the Baton Rouge 
area, Louisiana: U.S. Geol. Survey Water-Supply Paper 1296, 138 p., 1955.

Large quantities of fresh ground water are available, but water levels have declined and some salt-water contamination is found. The potential supply is described.

Meyner, Robert B.

(and Baumer, William H., and Capen, Charles H.). New Jersey water supply development: Am. Water Works Assoc. Jour., v. 49, no. 8, p. 969-985, 1957.

A panel discussion concerned principally with a committee report on the Raritan basin.

Michigan Water Resources Commission.

1. Report on water resources conditions and uses in Paw Paw River basin: Mich. Water Resources Comm., 41 p., 1955.

The report includes a general description, surface and ground-water resources, uses, pollution status, and recommendations for management of the water resources.

2. Report on water resources conditions and use in the Huron River basin: Mich. Water Resources Comm., 149 p., 1957.

Middleton, Foster H.

An ultrasonic current meter for estuarine research: Jour. Marine Research, v. 14, no. 2, p. 176-186, 1955.

An instrument that measures the velocity and direction of water flow in estuaries is described.

Midgley, A. R.

Water table studies in some Vermont soils: Vt. Agr. Expt. Sta. Bull. 597, 19 p., 1957.

Millar, G.

International Passamaquoddy tidal power project: Eng. Jour., v. 41, no. 10, p. 67-74, 1958.

Joint investigations suggest a 2-pool arrangement which will provide continuous power varying between 100,000 and 375,000 kilowatts.

Miller, A. R. See Redfield, A. C.

Miller, Carl R. See Borland, W. M., 1; Mostafa, M. G.

Miller, Dalton G. See Manson, P. W.

Miller, David H.

1. Snow cover and climate in the Sierra Nevada, California: Berkeley, Calif., Calif. Univ. Press, 1955.

2. The influence of open pine forest on daytime temperature in the Sierra Nevada: Geog. Rev., v. 46, p. 209-218, Apr. 1956.

The warmth of the climate over deep snow is explained by the reaction of trees to radiation.

Miller, J. D., JR.

1. Ground water in the vicinity of Bryce State Hospital, Tuscaloosa County, Alabama: Ala. Geol. Survey Inf. Ser. 12, 7 p., 1958.

2. (and Causey, L. V.). Geology and ground-water resources of Tuscaloosa County, Alabama; and interim report: Ala. Geol. Survey Inf. Ser. 14, 71 p., 1958.

Miluer, John F. See also Paulhus, J. L. H.

(and Paulhus, J. L. H.). Rainfall-runoff relation for small basins: Am. Geophys. Union Trans., v. 38, p. 216-218, 1957. 
A graphical rainfall-runoff relation for a basin of 4.1 square miles is derived and is found to be applicable to other small basins. (Discussion by Louis A. Koffman, and authors' closure, v. 39, p. 128-129, 1958.)

Miller, John P. See also Leopold, L. B., 1.

High mountain streams; effects of geology on channel characteristics and bed material: N. Mex. Bur. Mines and Mineral Resources Mem. 4, 51 p., 1958.

The purpose of the reported study was to test the range of validity of certain conclusions reached in investigations of graded streams. Measurements of channel dimensions, bed material, and other properties were made on streams in Sangre de Cristo Range, N. Mex. Efforts to segregate specific effects of geology on stream characteristics are described, and the problem of equilibrium in mountain streams is considered.

Miller, Lynn M. See Bechert, C. H.

Mille R, R. D. See Bolt, G. H.

Miller, Robert W. See also Hannaford, J. F., 2.

Ceilings unlimited: Western Snow Conf. Proc., p. 69-70, Apr. 1957.

The use of helicopters in snow surveying is described.

Milligan, Cleve H.

1. Pumping ground water for irrigation and drainage: Am. Soc. Civil Engineers Trans., v. 122, p. 228-234, 1957.

Planned utilization of ground water produces both irrigation and drainage benefits.

2. The use of Fourier series in streamflow forecasting: Western Snow Conf. Proc., p. 45-52, Apr. 1957.

A method utilizing Fourier series is applied to forecasting the runoff of Logan River. Variations of the method are suggested. (Discussion by George R. Hamburg and H. Boyd Phillips.)

\section{Milmoe, Wheeler.}

(and Van Lare, Frank E.). New York State water law would create regional planning units: Water Works Eng., v. 111, no. 11, p. 1020-1021, 1958.

A preliminary bill introduced in the 1958 session of the legislature for study purposes only is described.

Milne, J. A. S. See Arden, R. S.

Miner, Norman H.

(and Trappe, James M.). Snow interception, accumulation, and melt in lodgepole pine forests in the Blue Mountains of eastern Oregon: U.S. Forest Service, Pacific Northwest Forest and Range Expt. Sta. Research Note 153, 4 p., 1957.

The report discusses 1 year's data from snow courses and precipitation gages within a lodgepole pine stand and in adjacent openings.

Mississippi BoARd of Water Commissioners.

Facts about Mississippi's water resources: Miss. Board Water Comm., 59 p., 1958.

A nontechnical report covering water laws, facts about surface and ground-water supplies, opportunities for water storage, and activities of the Board of Water Commissioners.

\section{Mississippi River Commission.}

Annual maximum, minimum, and mean discharges of the Mississippi River and its outlets and tributaries to 1953: U.S. Army Corps Engineers, Miss. River Comm., 140 p., 1955. 
Mississippi Water Resources Policy Commission.

Water for the future in Mississippi: Miss. Water Resources Policy Comm., 55 p., 1955 .

This report to the legislature includes climate, surface and ground-water supplies, present and prospective water use, water laws, problems of imbalance, and recommendations.

Mitchell, C. G. See Connor, J. G.

Mitchell, J. Murray, Jr.

The weather and climate of Alaska: Weatherwise, v. 11, no. 5, p. 151-160, 1958.

A general description with maps and tables is given.

Mitchell, William D.

Flow duration of Illinois streams: Ill. Div. Waterways Pub., 189 p., 1957.

This report provides flow-duration data at gaging stations and a means of estimating the probable data for ungaged areas.

Moeller, Dade W. See Kramer, H. P.

Molansky, S. See Schoner, R. W.

Moltke, AL.

Integrated management of timber, water, forage and wildlife experience as practiced by lumber companies: Jour. Range Management, v. 9, no. 3, p. 111-112, May 1956.

The practices of an Oregon lumber company are described.

Mondrillo, George.

Thermodynamics of transpiration in heavy forest during active snow melt: Western Snow Conf. Proc., p. 20-25, Apr. 1956.

Actual and potential evapotranspiration are equal during a snowmelt period. Computations for an energy balance are given.

Mondschein, Herman F. See Ray, W. E.

Monson, O. W. See also Dusenberry, H. L.

(and Quesenberry, J. R.). Putting flood waters to work on rangelands: Mont. Agr. Expt. Sta. Bull. 543, 39 p., 1958.

Montana State Engineer.

1. Water resources survey, Deer Lodge County, Montana: Mont. State Engineer, 18 p., 1955.

2. Water resources survey, Silver Bow County, Montana: Mont. State Engineer, 22 p., 1955.

3. Water resources survey, Broadwater County, Montana: Mont. State Engineer, 19 p., 1956.

4. Water resources survey, Jefferson County, Montana: Mont. State Engineer, 29 p., 1956.

Montana University School of Law.

Is a preference among distributors of federal power justified?: Missoula, Mont. State Univ. Press, 207 p., 1957.

Proceedings of the first annual water resources conference at Montana State University are reported. Six papers with discussions are given.

Montgomery, J. H. See Breeding, S. D.

Moody, W. T. See Stevens, J. C. 


\section{Mook, Conrad P.}

Surface streamlines associated with the torrential rains of August 18-19, 1955 in the Northeastern United States: Monthly Weather Rev., v. 83, no. 8, 1955.

Streamline patterns reveal a marked zone of convergence which lay close to the subsequent path of the storm center.

\section{Moore, A. M.}

Measuring streamflow under ice conditions: Am. Soc. Civil Engineers Proc., v. 83, no. HY 1, Paper 1162, 12 p., 1957.

Effects of ice formation on stage-discharge relationships are explained and the occurrence and effect of surface, frazil, and anchor ice are described. The accuracy of ice-affected records is appraised. (Discussions by Charles E. Behlke, Steponas Kolupaila, v. 83, no. HY 4, Paper 1348, p. 9-14, 1957, author's closure, v. 84, no. HY 1, Paper 1558, p. 5-6, 1958.)

Moore, Charlie M. See Renfro, G. W.

Moore, Jerrold A.

Planning for flood damage prevention: Ga. Eng. Expt. Sta. Spec. Rept. 35, 61 p., 1958.

Moran, P. A. P.

The statistical treatment of flood flows: Am. Geophys. Union Trans., v. 38, p. 519-523, 1957.

The estimation of return periods of floods is considered from the point of view of mathematical statistics. Confidence limits for 100- and 1,000-year floods on River Murray are given. (Discussions by E. J. Gumbel and G. N. Alexander, and author's closure, v. 39, p. 732-736, 1958.)

Moran, Willis T. See also Timblin, L. O., Jr., 1.

(and Garstka, Walter U.). The reduction of evaporation through the use of monomolecular films. Internat. Comm. Irrig. and Drainage, 3d Cong., San Francisco, Calif., 1957, v. 4, rept. 29, p. 1-16.

The report describes the progress that has been made in the technique of reducing evaporation losses through the use of monomolecular films on water surfaces, and it discusses the physical chemistry of the mechanism of the monomolecular layers and the hydrologic and biologic implications.

Moreejl, Ben.

Our nation's water resources, policies and politics: Chicago Univ. Law School, 266 p., 1956.

Lectures given at the University of Chicago, April and May 1956, and a foreword by Herbert Hoover are presented.

Morgan, Edward J.

Honolulu water supply: Am. Water Works Assoc. Jour., v. 49, no. 11, p. 1402-1413, 1957.

History, underground sources, mountain gravity sources, water quality, research and investigation, and long-range considerations are covered.

Morgan, Robert J. See Duke University School of Law.

Morisawa, Marie.

Accuracy of determination of stream lengths from topographic maps: Am. Geophys. Union Trans., v. 38, p. 86-88, 1957.

Stream lengths from topographic maps were obtained in two ways: (1) using only 
streams printed in blue and (2) including streams inserted into the drainage net wherever there are $V$-shaped contours. The second is preferred.

Morris, Samuel B.

1. (and Powers, Harold J., Banks, Harvey O., Holsinger, Henry, McFarland, John W., Berry, William L., Allen, Bruce F., Cassidy, William F., Spencer, Clyde H., and Howland, Wallace). The California water plan and its administration: Am. Water Works Assoc. Jour., v. 49, no. 2, p. 89-147, 1957.

The State's water problems and proposed solutions are discussed.

2. Conflicting demands for water: Eng. News-Rec., v. 158, no. 23, p. 57-58, June 6, 1957.

Many conflicts exist but there are ways to resolve or avoid them.

3. Resolving conflicting demands for water: Am. Soc. Civil Engineers Proc., v. 84, no. IR 1, Paper 1501, 8 p., 1958.

In some arid areas, irrigation use creates major international problems. Domestic and industrial use can give the most benefits. (Discussion by J. Earnest Flack, v. 84, no. IR 3, Paper 1784, p. 27-31, 1958, and author's closure, v. 85, no. IR 1, Paper 1986, p. 71-72, 1959.)

Morse, Richard M.

(and Rattra, Maurice, Pacquette, R. G., Barnes, C. A.). The measurement of transports and currents in small tidal streams by an electromagnetic method: Wash. Univ. [Seattle] Dept. Oceanography Tech. Rept., no. 57, 70 p., 1958.

Potentials associated with saline water moving through the earth's magnetic field were measured across tidal streams, and potentials in relation to water transport and calibration with independent transport or velocity measurements were considered.

Morse, Roy W. See Bechert, C. H.

Moskovitz, A. See Kuder, W. B.

Mostafa, M. Gamal. See also Brooks, N. H.; Fathy, A.

River-bed degradation below large-capacity reservoirs: Am. Soc. Civil Engineers Trans., v. 122, p. 688-695, 1957.

A method of predicting the condition of equilibrium attained by a riverbed subject to degradation is presented. The rate of degradation may be computed by a trial method. (Discussion by Whitney M. Borland and Carl R. Miller, Maurice L. Albertson and Hsin-Kuan Liu, and Serge Leliavsky.)

\section{Moulder, E. A.}

(and Kohout, F. A.). Ground-water factors affecting drainage in the First Division, Buffalo Rapids Irrigation Project, Prairie and Dawson Counties, Montana, with a section on chemical quality of the water, by E. R. Jochens: U.S. Geol. Survey Water Supply Paper 1424, 198 p., 1958.

The detailed hydrologic studies on which this report is based have revealed the causes of poor drainage. Possible means of alleviating the waterlogging are suggested.

Moulton, E. Q.

The acid mine-drainage problem in Ohio: Ohio State Univ. Studies, Eng. Ser., v. 26, no. 5, 158 p., 1957.

An annotated bibliography on acid-mine drainage and allied subjects is given.

Mower, R. W. See also Nace, R. L., 1.

(and Nace, R. L.). Water consumption by water-loving plants in the Malad valley, 
Oneida County, Idaho: U.S. Geol. Survey Water-Supply Paper 1412, 33 p., 1957. A study of plant species and their distribution in relation to the geology and hydrology of their environment is reported.

MoYers, W. H.

OFS Mines defeat salt water problem: Eng. and Mining Jour., v. 159, no. 1, p. 84-87, 1958.

The report describes an electrodialysis-process installation for reducing total dissolved solids from 4,000 to 1,000 parts per million in South Africa.

Moyle, R. C. See Eschner, A. R.

Muckel, Dean C. See also Blaney, H. F., 3; Robinson, A. R., Jr., 2.

1. Pumping ground water so as to avoid overdraft, in U.S. Department of Agriculture, Water: Yearbook of Agriculture 1955, p. 294-301.

A discussion of the occurrence and movement of ground water and the problem of planned utilization of ground-water reservoirs is given.

2. (and Schiff, Leonard). Replenishing ground water by spreading, in U.S. Department of Agriculture, Water: Yearbook of Agriculture 1955, p. 302-310.

Four spreading methods and the advantages and disadvantages of each are described.

Muegge, O. J.

Artificial recharging of water-bearing formations: Am. Water Works Assoc. Jour. v. 50, no. 2, p. 168-174, 1958.

A general description of practices and experiences is given, and proposed research in, Wisconsin is outlined.

Mueller, E. A.

Study on intensity of surface precipitation using radar instrumentation; final report on Contract DA-36-039 SC-64723: Ill. Water Survey, Mar. 1958.

Muilenburg, Garretr A.

The 1954 drought and its effect on ground water: Am. Soc. Civil Engineers Proc., v. 82, no. SA 3, Paper 1016, 10 p., 1956.

A cumulative deficiency in precipitation of 22.77 inches in 2 years was responsible for the disastrous drought conditions of 1954 in Missouri.

Mundorff, J. C.

(and Jordan, P. R.). Fluvial sediment in Whitehead watershed and Whitehead reservoirs, Nebraska, April 1955 to September 1956: U.S. Geol. Survey Circ. 406, 21 p., 1958.

This report describes the characteristics of the suspended sediment transported into and discharged from the reservoirs.

Muntz, Alfred Philir.

Recent glacier activity in the Taku Inlet area, southeastern Alaska: Arctic, v. 8, no. 2, p. 83-95, 1955.

This paper discusses the significant features of recent fluctuations of the lower Norris and Taku glaciers.

Murphy, John F.

Uranium-bearing water in the Crow Creek and Muskrat Creek areas, Fremont County, Wyoming: Wyo. Geol. Survey Rept. Inv., no. 5, 15 p., 1956.

Water samples contain as much as 150 parts per billion uranium from Crow Creek and as much as 340 parts per billion from Muskrat Creek. 
Murphy, J. J. See Rasmussen, W. C., 3.

Murphy, Warren T. See Brown, C. B., 1.

MURRAY, RAYMOND C.

Recent sediments of three Wisconsin lakes: Geol. Soc. America Bull., v. 67, p. 883-910, 1956.

Analysis of sediments in Lake Mendota indicates an abrupt change in sedimentation in the recent past. It is postulated that the change began in the last century with the development of the city of Madison and the surrounding farm community.

Musgrave, George W.

1. How much of the rain enters the soil?, in U.S. Department of Agriculture, Water: Yearbook of Agriculture 1955, p. 151-159.

Infiltration rates vary with the type and condition of the soil and with the amount of ground cover. Methods of measuring infiltration are described, and the increased infiltration resulting from wise land management is shown.

2. If it rains: Soil Conserv., v. 20, no. 6, p. 123-126, 1955.

An explanation of infiltration and of moisture loss from the soil is given.

3. When the rains come: Soil Conserv., v. 20, no. 11, p. 243-245, 1955.

Effects of tillage practices on the infiltration rate and water-holding capacity of soil are discussed.

4. How does vegetation affect water yield: Soil Conserv., v. 22, no. 6, p. 126-128, 1957.

General principles are outlined, but more research is needed.

Musgrove, Rufus $\mathrm{H}$.

Flood of June 9, 1957, at Perry, Florida: Fla. Geol. Survey Inf. Circ., no. 17, 12 p., 1958.

Rainfall, peak-flow and flood-elevation data are given.

Mussey, Orville D.

1. Water requirements of the pulp and paper industry: U.S. Geol. Survey WaterSupply Paper 1330-A, p. 1-71, 1955.

Manufacturing processes are described with emphasis on the amount and quality of water required.

2. Water requirements of the rayon and acetate-fiber industry: U.S. Geol. Survey Water-Supply Paper 1330-D, p. 141-179, 1957.

Manufacturing processes are described, and the quantity and quality of water required are given.

Mutz, Philip B. See Powell, W. J., 2.

NACE, R. L. See also Mower, R. W.

1. (and West, S. W., and Mower, R. W.). Feasibility of ground-water features of the alternate plan for the Mountain Home project, Idaho: U.S. Geol. Survey Water-Supply Paper 1376, 121 p., 1957.

The alternate plan would divert water from Boise River to the project. Part of the diverted water would be replaced by pumping ground water in the Boise valley.

2. (and McQueen, I. S., and Van't Hul, Arthur). Records of springs in the Snake River valley, Jerome and Gooding Counties, Idaho, 1899-1947: U.S. Geol. Survey Water-Supply Paper 1463, 62 p., 1958.

This report includes descriptive data, a brief history of work done, and all obtainable records for the period 1899-1947. 
3. (and Bieber, P. P.). Ground-water resources of Harrison County, West Virginia: W. Va. Geol. and Econ. Survey Bull., no. 14, 55 p., 1958.

The report describes public water supplies; occurrence, availability, and use of gound water; stratigraphic units and their water-bearing properties, and groundwater conditions in local areas.

Namias, Jerome.

Some meteorological aspects of drought-with special reference to the summers of 1952-54 over the United States: Monthly Weather Rev., v. 83, no. 9, p. 199-205, 1955.

Some climatologic charts are shown illustrating how drought conditions differed from the normal situation. The hope is expressed that the future may bring a general solution to the drought problem.

NAsh, J. E.

1. (and Farrell, J. P.). A graphical solution of the flood-routing equation for linear storage-discharge relation: Am. Geophys. Union Trans., v. 36, p. 319-320, 1955.

The method is described. (Discussion by Charles D. Hopkins, Jr., v. 37, p. 500-501, 1956.)

2. Frequency of discharges from ungaged catchments: Am. Geophys. Union Trans., v. 37, p. 719-725, 1956.

The frequency of discharges from ungaged catchments is related to rainfall frequency and the unit hydrograph for the catchment. Application of the method to catchments in Ireland is demonstrated.

Nazir, Mohammad. See Petersen, J. S.

Nees, Joe K. See Hatcher, M. P.; Hopkins, G. J.

Nerll, J. C. See Huff, F. A., 4, 5, 6, 7.

Nelson, Arthur W., JR.

Getting a watershed management program started on a municipal watershed-the experience of Meridian, Mississippi: Soc. Am. Foresters Proc., p. 34-36, 1958.

Watershed management for both water and timber is suggested.

Nelson, C. Emil.

(and Domingo, Clifford E.). Data on weather from 1924-1957 at the irrigation experiment station near Prosser, Washington: Wash. Agr. Expt. Sta. Bull. 593, 37 p., 1958.

A compilation of temperature, precipitation, wind-speed, evaporation, and frost data is presented.

Nelson, Gerald H.

Flow regimes of a drop-inlet spillway: Agr. Eng., v. 37, no. 3, p. 177-179, 1956.

Hydraulic-model tests show that the flow into a drop-inlet spillway tower may be governed by five head-discharge relationships.

Nelson, Herbert C. See Straub, L. G., 1.

Nelson, M. W. See also Irving, R. N.

(and Simons, W. D.). A modern forecast for Columbia River at Birchbank, B. C.:

Western Snow Conf. Proc., p. 8-11, Apr. 1956.

The April through September runoff is related by multiple-regression techniques to snow conditions, base flow, and precipitation. 


\section{Nelson, Robert E.}

Soil-vegetation survey of a central Sierra snow zone watershed: U.S. Forest Service, Calif. Forest and Range Expt. Sta. Misc. Paper 21, 43 p., 1957.

The report maps and describes the timber stands, vegetation, and soils of the Castle Creek watershed (Central Sierra Snow Laboratory) as a basis for studying methods of improving water yield.

Netboy, Anthony.

Salmon of the Pacific Northwest: Portland, Oreg., Binfords and Mort, 122 p., 1958. The conflict between fish and dams is described.

Neville, John F.

Is the writing of flood insurance feasible?: Am. Soc. Civil Engineers Proc., v. 83, no. HY 2, Paper 1202, 7 p., 1957.

This paper explains why privately sponsored flood insurance is unfeasible and reviews the offer of industry to assist in putting into effect the Federal Flood Insurance Act of 1956. (Discussions by E. M. Laursen and A. Toch, v. 83, no. HY 5, Paper 1417, p. 29-30, 1957; and author's closure v. 84, no. HY 1, Paper 1558, p. 39, 1958.)

Nevins, T. H. F. See Matthes, G. H.

New England-New York Inter-Agency Committee.

Land and water resources of the New England-New York region: Senate Doc. 14, U.S. 85th Cong., 1st sess., v. 2, 1957.

This is a comprehensive report of the interagency committee appointed by the President of the United States. Part 1 is the general report. Part 2 is the technical report, with detailed studies of the river basins and special subjects.

New Mexico State Engineer.

1. Climatological summary, New Mexico-temperature, frost and evaporation: N. Mex. State Engineer Tech. Rept., no. 5, 277 p., 1956.

The following information is given: Monthly and annual temperatures, 1850-1954; average and extreme frost dates, 1850-1954; and monthly and annual evaporation, 1912-54.

2. Climatological summary, New Mexico, precipitation 1849-1954: N. Mex. State Engineer Tech. Rept., no. 6, 407 p., 1956.

Monthly and annual values are given.

New York State.

1. Our lands, forests, waters and air: New York State Joint Legislative Comm. Nat. Resources, 285 p., 1955.

This report to the legislature includes two papers on forests and water yields and a section on conserving our water resources.

2. Report of the temporary State commission on irrigation: N.Y. Legislative Doc. 27, 119 p., 1957.

The report describes economic importance of irrigation, legal aspects, methods of development, and conditions on Long Island and along the Erie Barge Canal.

Newcome, Roy, JR.

1. Ground water in the Central Basin of Tennessee-a progress report: Tenn. Div. Geology Rept. Inv., no. 4, 81 p., 1958.

Ground water occurs chiefly in solution channels in limestone. Well yields are low and water quality poor. Records of 600 wells are given. 
2. (and Smith, Ollie, Jr.). Ground-water resources of the Cumberland Plateau in Tennessee-a reconnaissance report: Tenn. Div. Water Resources, 72 p., 1958.

Ground water occurs almost exclusively in fractured sandstone beds and is under artesian pressure. Well yields of $\mathbf{5 0}$ gallons per minute or greater are rare. Water is generally potable.

Newpont, Thomas G. See also Cronin, J. G.

Reconnaissance of the ground-water resources of the Elkhorn River basin above Pilger, Nebraska, with a section on chemical quality of the water, by Robert A. Krieger: U.S. Geol. Survey Water-Supply Paper 1360-I, p. 715-754, 1957. The reconnaissance was made to determine the possibility of expanding the use of ground water for irrigation. The quantity and chemical quality are adequate to permit additional development.

Newton, J. G. See Sutcliffe, H., Jr.

Nichols, M. StaRr.

(and McNall, Dorothy R.). Strontium content of Wisconsin municipal waters:

Am. Water Works Assoc. Jour., v. 49, no. 11, p. 1493-1498, 1957.

Analyses of 380 waters showed a strontium content ranging from less than 0.1 to 39.1 parts per million.

Nichols, Marvin C.

Action on Texas water problems: Am. Water Works Assoc. Jour., v. 50, no. 9, p. 1160-1165, 1958.

Water district, municipal, and State programs are described.

Nielsen, Donald R. See Adams, J. E.

Niles, Thomas M.

Dispersal of pollution by tidal movements: Am. Soc. Civil Engineers Proc., v. 83, no. SA 5, Paper 1408, 18 p., 1957.

Calculation of the total load which can be put on tidal waters is a major problem. An approach to the problem is given, with data on the Potomac and Delaware Rivers. (Discussions by D. I. H. Barr, v. 84, no. SA 2, Paper 1614, p. 5-6, 1958; Alex N. Diachishin, v. 84, no. SA 3, Paper 1688, p. 5-7, 1958.)

Nrmmo, W. H. R. See Lane, E. W., 1.

NingaRd, L. G.

Watershed control in Maryland: Am. Water Works Assoc. Jour., v. 48, no. 2, p. 166-170, 1956.

The program used on forested land is described. (Discussion by R. C. Willson.)

Niyogi, Dipankar. See Hadley, R. F.

Nizery, A. See Lane, E. W., 2.

Noble, E. L. See Clark, L. K.

Nordenson, Tor J. See Kohler, M. A., 1; Kresge, R. F., 1.

NoRDYKe, LewIS.

Farming with sewage: Soil and Water, v. 4, no. 7, p. 14-17, 1955.

A successful operation in Texas is reported.

Norris, Stanley E.

1. Sand at the top of the Niagara group as a source of water in west-central Ohio:

Ohio Jour. Sci., v. 56, no. 2, p. 93-100, 1956.

Geology and ground-water yields are described. 
2. Characteristics of limestone and dolomite aquifers in western Ohio: Am. Water

Works Assoc. Jour., v. 49, p. 464-468, 1957.

An investigation to appraise these rocks quantitatively as aquifers is described.

3. Groundwater investigations: Water Well Jour., v. 11, no. 7, 1957.

The problems facing ground-water investigators in Ohio are described.

4. (and Spicer, H. Cecil). Geological and geophysical study of the preglacial Teays

Valley in west-central Ohio: U.S. Geol. Survey Water-Supply Paper 1460-E, p. 199-232, 1958.

Earth-resistivity methods were used to locate the buried valley and to trace its course. Test holes revealed the depth of the buried valley, gradient and configuration, and the character of the valley-fill deposits.

North Carolina Board of Water Commissioners.

1. First biennial report of the North Carolina Board of Water Commissioners:

N.C. Board Water Commissioners, 85 p., 1956.

The report describes water use and includes many water facts.

2. Second biennial report of the North Carolina Board of Water Commissioners:

N.C. Board Water Commissioners, 34 p., 1958.

The report describes briefly the available water supply, uses, problems, small watershed protection, and flood-plain zoning.

North Carolina Division of Water Resources, Inlets, and Coastal WaterWAYS.

1. Water resources of North Carolina: N.C. Div. Water Resources, Inlets, and Coastal Waterways, v. 1, 185 p., 1955.

This report covers for the State as a whole, regional characteristics, shortages of water, uses of water, quality of water, streamflow, abatement of stream pollution, soil conservation, watershed management, navigation, flood control, and other subjects.

2. Water resources of North Carolina, Neuse River basin: N.C. Div. Water Resources, Inlets, and Coastal Waterways, v. 2, 104 p., 1955.

This is a comprehensive report on surface and ground-water occurrence, chemical quality of the water, water use, pollution abatement, soil conservation, watershed management, navigation, and flood control.

3. Water resources of North Carolina, Yadkin-Pee Dee River basin: N.C. Div.

Water Resources, Inlets, and Coastal Waterways, v. 3, 142 p., 1955.

This is a comprehensive report on surface and ground-water occurrence, chemical quality of the water, water use, pollution abatement, soil conservation, watershed management, navigation, and flood control.

4. Water resources of North Carolina, Chowan River basin: N.C. Div. Water

Resources, Inlets, and Coastal Waterways, v. 4, 60 p., 1955.

This is a comprehensive report on surface and ground-water occurrence, chemical quality of the water, water use, pollution abatement, soil conservation, watershed management, navigation, and flood control.

5. State and federal water laws and considerations affecting future legislation:

N.C. Dept. Conserv. and Devel., 151 p., 1956.

The report consists entirely of an assembly of material from several sources.

North Carolina Stream Sanitation Commitree.

Classifications and water quality standards assigned to the waters of the White Oak

River basin: N.C. Board Health, 11 p., 1956.

North Dakota Water Conservation Commission.

North Dakota stream flow data: N. Dak. Water Conserv. Comm., 245 p., 1957. 
A summary of monthly and annual mean discharge and of yearly extremes through 1955 is given.

Northcraft, Martin.

(and Westgarth, Warren C.). Water quality data inventory supplement: Oreg. Water Resources Board Bull. 1, 71 p., 1957.

Norton, Robert A.

Connecticut Flood Planning Session, IV-Application to bridges: Conn. Soc. Civil Engineers, 73d ann. rept., p. 103-107, 1957.

The report describes the methods used to determine the design flood for bridge design.

Nupen, Wilhelm.

(and Rigby, Malcolm). Annotated bibliography on tropical cyclones, hurricanes and typhoons: Meteorol. Abstracts and Bibliography, v. 7, no. 9, p. 1115-1163, Sept. 1956.

NutT, David C.

Explorations in Labrador: Eastern Snow Conf. Proc., v. 3, p. 99-106, 1955.

A description of the physical geography is given.

O'Brrne, John C. See Timmons, J. F.

O'Connor, Donald J.

(and Dobbins, William E.). The mechanism of reaeration in natural streams: Am.

Soc. Civil Engineers Proc., v. 82, no. SA 6, Paper 1115, 30 p., 1956.

Turbulent flow theory has been used to formulate a theory of reaeration. Results of laboratory and field studies were used to substantiate the theoretical formulas. (Discussions by Thomas R. Camp, v. 83, no. SA 2, Paper 1227, p. 9-14, 1957; Alex N. Diachishin, A. Pasveer, M. C. Rand, v. 83, no. SA 3, Paper 1288, p. 3-13, 1957; and authors' closure, v. 84, no. SA 1, Paper 1557, p. 3-7, 1958.)

O'Connor, Howard G.

Ground-water resources of Osage County, Pt. 3 of Geology, mineral resources, and ground-water resources of Osage County, Kansas: Kans. Geol. Survey Repts., v. 13, 50 p., 1955.

The report gives a brief discussion of the principles of the occurrence of ground water and data on the occurrence, quality, quantity, and availability of ground water in Osage County.

Ogata, Gen. See Richards, L. A., 2.

Ogrosky, Harold O. See also Ackermann, W. C., 2.

1. Treatment of small watersheds: Land and Water, v. 1, no. 3, 1955.

This paper describes how a watershed is planned for treatment and the need for cooperation in the planning and installation of a watershed program.

2. The hydrologist looks upstream: Soil Conserv., v. 20, no. 8, p. 171-175, 1955.

The complex problems of a hydrologist engaged in watershed studies are described.

3. Treatment of small watersheds: Land Water, v. 2, no. 1, p. 13-15, 1956.

In order to develop watershed programs that will produce the greatest benefit for each dollar expended, we must study the watershed characteristics and develop a program to fit its particular needs.

Ohio Legislative Service Commission.

1. Water rights in Ohio: Ohio Legislative Service Comm. Research Rept., no. 1, 44 p., 1955. 
This is a report of an inquiry into water-rights law and the physical and economic problems which relate to water supply.

2. Drainage laws in Ohio: Ohio Legislative Service Comm. Research Rept., no. 2, 13 p., 1955.

3. Water pollution control in Ohio: Ohio Legislative Service Comm. Research Rept., no. 3, 19 p., 1955.

OKI, Iwao. See Kindsvater, C. E., 2.

Olson, EarL F. See Seigworth, K. J.

Onellion, Frank E.

1. (and Criner, James H., Jr.). Ground-water resources of Chicot County, Arkansas: Ark. Geol. and Conserv. Comm. Water Resources Circ. 3, 27 p., 1955.

2. Geology and ground-water resources of Drew County, Arkansas: Ark. Geol. and Conserv. Comm. Water Resources Circ. 4, 32 p., 1956.

Orlob, Gerald T. See also Kaufman, W. J., 1, 2.

1. (and Radhakrishna, G. N.). The effects of entrapped gases on the hydraulic characteristics of porous media: Am. Geophys. Union Trans., v. 39, p. 648$659,1958$.

Experiments with prepared porous media indicate that a 10 percent increase in air content of media voids may produce a 15 percent reduction in "effective porosity," a 35 percent decrease in permeability, and a 50 percent reduction in hydraulic dispersion.

2. (and Butler, Robert G.). Soil lysimeters in waste water reclamation studies: Am. Soc. Civil Engineers Trans., v. 123, p. 116-136, 1958.

The behavior of five previous agricultural soils under water and sewage spreading conditions is evaluated, and a comparison is made between field and lysimeter performance for two of these soils. Lysimeters are shown to provide an economical means of predicting full-scale field spreading performance. (Discussion by Ralph Stone.)

3. Eddy diffusion in open channel flow: Calif. Univ. Water Resources Center Contr., no. 19, 144 p., 1958.

Experimental investigation of fundamental mechanisms of eddy diffusion was undertaken with two major objectives: (1) to determine effect of characteristics of flow, such as eddy size, turbulence intensity velocity, depth, Reynolds number, and others on magnitude of eddy diffusion coefficient; and (2) to obtain solution for problem of diffusion from a line source in a two-dimensional turbulent stream.

ORR, How ARD K.

Effects of plowing on some forage production and hydrologic characteristics of a subalpine range in central Utah: U.S. Forest Service Intermountain Forest and Range Expt. Sta. Research Paper 47, 23 p., 1957.

Treatments improved quality and quantity of forage and are expected to provide control of overland flow and erosion as plant cover increases.

ORSANCO Aquatic Life Advisory Commitree.

1. Aquatic life water quality criteria: Sewage and Indus. Wastes, v. 27, no. 3, p. 321-331, 1955 .

The report gives the recommendations of the committee as to a practical definition of what constitutes waters capable of maintaining fish and other aquatic life.

2. Aquatic life water quality criteria: Sewage and Indus. Wastes, v. 28, no. 5, p. $678-690,1956$. 
In this second report, the committee states its findings and conclusions with regard to temperature, dissolved solids, settleable solids, chloride ion, fluoride ion and color.

Orth, R. P. See Matthai, H. F., 3.

Orville, Howard T.

1. What is weather modification?: Soil and Water, v. 5, no. 11, p. 12-13, 1956.

The work of the Advisory Committee on Weather Control is described.

2. Work accomplished to date by the Advisory Committee on Weather Control:

Western Snow Conf. Proc., p. 33-34, Apr. 1956.

This is a progress report.

3. Some aspects of weather modification (cloud seeding): Eastern Snow Conf. Proc., v. 4, p. 113-116, 1957.

The work of the Advisory Committee on Weather Control is described.

4. Weather modification-problems and possibilities of increasing water supplies: Jour. Soil and Water Conserv., v. 12, no. 5, p. 237-241, 1957.

The cloud-seeding evaluation programs undertaken by the Advisory Committee on Weather Control are described.

Osborn, Ben.

How rainfall and runoff erode soil, in U.S. Department of Agriculture, Water: Yearbook of Agriculture 1955, p. 126-135.

Splash erosion, scour erosion, and their effects are described.

Osmond, J. Kenneth. See Judson, S.

Ostre, B. See Army, T. J.

OtTon, E. G.

Ground-water resources of the southern Maryland coastal plain: Md. Dept. Geology, Mines, and Water Resources Bull. 15, 347 p., 1955.

Chemical analyses, well records, and well logs are included in this comprehensive report.

Outlaw, Donald E. See Barksdale, H. C., 2.

Overbeck, Robert M.

(and Slaughter, Turbit H., and Hulme, Arthur E.). The water resources of Cecil, Kent, and Queen Annes Counties: Md. Dept. Geology, Mines, and Water Resources Bull. 21, 478 p., 1958.

The report describes the occurrence, availability, quality, and use of the ground and surface-water resources. Many data are included.

Owen, George E.

Legal implications of stream pollution: Sewage and Indus. Wastes, v. 27, no. 4, p. 487-493, 1955.

This paper is concerned with the topic of riparian rights.

Packer, Paul E. See also Gleason, C. H., 1.

1. Watershed management problems and research needs in the Region 1 area:

U.S. Forest Service Watershed Management Conf. Northern Region Proc., 106 p., 1956.

Characteristics of lands giving rise to problems are discussed and research needed to provide solutions is suggested.

2. Management of forest watersheds and improvement of fish habitat: Am. Fisheries Soc. Trans., v. 87, p. 392-397, 1958.

The report discusses important hydrologic processes that operate on watersheds. 
It emphasizes protection and management in relation to streamflow quality to maintain desirable fish habitat.

Pacquette, R. G. See Morse, R. M.

Paderi, F. See Kandaswamy, P. K.

PAFFord, R. J., JR.

Operation of Missouri River main stem reservoirs: Am. Soc. Civil Engineers Proc., v. 83, no. WW 3, Paper 1370, 1957.

Operation of the system of six multiple-use reservoirs and the development of operating plans are discussed.

PAgE, J. B. See Bloodworth, M. E., 1, 2, 3.

PAGE, W. B. See Fournelle, H. J.

Pagenhart, T. H. See Anderson, H. W., 4.

Pagon, W. Watters. See Prugh, B. J., 1.

Painter, R. H.

Direction control in deep-well drilling: Agr. Eng., v. 37, no. 8, p. 548-549, 1956.

Methods of measuring deflection during drilling in deep water-well holes are given.

Pair, Claude H. See Criddle, W. D., 2.

Palange, Ralph C. See also Hartung, H. O.

(and Megregian, Stephen). A national water quality basic data program: Am. Soc. Civil Engineers Proc., v. 84, no. SA 2, Paper 1606, 6 p., 1958.

The Public Health program for obtaining chemical, biological, and radiological analyses of the nation's water resources on a long-term basis is described.

Palmer, Harold S.

Origin and diffusion of the Herzberg principle with especial reference to Hawaii: Pacific Sci., v. 11, no. 2, p. 181-189, 1957.

A history of the Herzberg principle is given, and the application of the principle to understanding the artesian conditions at Honolulu is discussed.

Palmer, Robert S.

Agricultural drought in New England: N. H. Univ. Agr. Expt. Sta., Tech. Bull. 97, 51 p., 1958.

The Blaney-Criddle formula has been used to determine the seasonal soil moisture requirements of crops at 15 locations within the region. Crop moisture needs have been correlated with the effective seasonal rainfall to determine the seasonal soil moisture deficiency.

Panofsky, Hans A.

(and Brier, Glenn W.). Some applications of statistics to meteorology: Pa. State Univ., Coll. Mineral Indus., 224 p., 1958.

The first part is devoted to "classical" statistics. The second discusses relationships between variables, time series, space variation, and applications to weather forecasting.

Paquette, Robert G. See Bader, R. G.

Parizer, Elden J. See Woodruff, J. F.

Parker, Frank L.

Radioactive tracers in hydrologic studies: Am. Geophys. Union Trans., v. 39, p. 434-439, 1958. 
Experiments were made in lakes to determine eddy diffusion coefficients and in rivers to determine average velocity of stream and the dilution in streams. A mathematical formulation for general use in determining dilution and dispersion in streams was established.

Parker, Garald G.

1. The encroachment of salt water into fresh, in U.S. Department of Agriculture,

Water: Yearbook of Agriculture 1955, p. 615-635.

The general nature of salt-water encroachment is described, and specific details of encroachment and salt-contamination problems in the United States are given. 2. (and Ferguson, G. E., and Love, S. K.). Water resources of southeastern Florida, with special reference to the geology and ground water of the Miami area: U.S. Geol. Survey Water-Supply Paper 1255, 948 p., 1955.

This is a comprehensive report describing the climate, geology, geomorphology, ground water, surface water, salt-water encroachment, and water quality and including a section on hydrologic studies.

Parsons, Donald A.

Coshocton-type runoff samplers: U.S. Dept. Agriculture, ARS-41-2, 10 p., 1955.

The report gives the results of a cooperative effort to determine and correct, if possible, the causes for the relatively poor showing of the Coshocton Samplers in the field.

Partridge, Everett P.

Your most important raw material: Am. Soc. Testing Materials, 27 p., 1958.

This lecture was presented before the sixtieth annual meeting of the American

Society for Testing Materials.

Pasveer, A. See O'Connor, D. J.

Patterson, Calvin C. See Li, W. H., 2.

Patterson, J. R. See Williams, L. G., 1.

Patton, C. P.

Climatology of summer fogs in the San Francisco Bay area: Berkeley, Calif. Univ. Press, 1956.

Paulhus, Joseph L. H. See also Linsley, R. K., Jr., 3; Miller, J. F.; Snyder, F. F., 2. (and Miller, John F.). Flood frequencies derived from rainfall data: Am. Soc.

Civil Engineers Proc., v. 83, no. HY 6, Paper 1451, 18 p., 1957.

A long record of peak discharges may be synthesized for a basin if the available streamflow record is long enough to derive a unit hydrograph and to test the rainfallrunoff relation. (Discussions by H. C. Riggs and Manuel A. Benson, v. 84, no. HY 3, Paper 1690, p. 11-19, 1958; C. O. Clark; and authors' closure, v. 84, no. HY 6, Paper 1856, p. 13-23, 1958. Addendum to authors' closure, v. 85, no. HY 2, Paper 1950, p. 93-97, 1959.)

PaUll, John W. See Kindsvater, C. E., 2.

Paulson, Q. F.

(and Powell, J. E.). Geology and ground-water resources of the Upham area,

McHenry County, North Dakota: N. Dak. Geol. Survey Ground-Water Studies, no. 26, 66 p., 1957.

Peak, George W.

Forecasting natural runoff in relation to pumping for irrigation: Western Snow Conf. Proc., p. 14-16, Apr. 1955. 
Development and use of a forecasting equation in Mission Valley, Mont. are described.

Pearce, D. C. See Penrod, E. B.

Peck, Eugene L. See Love, L. D., 2.

Pecos River Commission.

Initial development, water salvage and salinity alleviation action programs, Pecos

River basin: Pecos River Comm., 1955.

The problems of recurring droughts, decreasing tributary flows, losses from phreatophytes, poor quality of water, destructive floods, sedimentation, and deterioration of irrigation works are defined. Programs to alleviate these problems are proposed.

Pecsok, Donald A. See Kŕramer, H. P.

Peek, Harry M.

1. (and Anders, Robert B.). Interim report on the ground-water resources of Manatee County, Florida: Fla. Geol. Survey Inf. Circ., no. 6, 38 p., 1955.

2. Ground-water resources of Manatee County, Florida: Fla. Geol. Survey Rept. Inv., no. 18, 99 p., 1958.

3. Record of wells in Manatee County, Florida: Fla. Geol. Survey Inf. Circ., no. 19, 199 p., 1958.

Peele, T. C. See van Bavel, C. H. M., 5.

Peirce, Laurence B.

Hydrology and surface-water resources of east-central Alabama, with a section on quality of water, by Eugene Brown: Ala. Geol. Survey Spec. Rept. 22, 318 p., 1955 .

The report describes water use and control, climate, topography, and geology of the area. Monthly and annual runoff in inches and a summary of yearly discharge are given for each gaging station. Flow-duration tables are given for stations having longer records. Chemical analyses are tabulated for 28 locations on major rivers. A section treats regional frequency studies, runoff-rainfall correlations, and evapotranspiration.

Pelletier, Charles J.

Connecticut Flood Planning Session, III-Application to channel lines: Conn. Soc. Civil Engineers, 73d ann. rept., p. 98-102, 1957.

A design flow, based on the Connecticut flood-flow formula, is used as a basis for locating encroachment lines.

Pendleton, Wendell. See Love, C. L.

Penman, H. L.

Estimating evaporation: Am. Geophys. Union Trans., v. 37, p. 43-46, 1956.

Evaporation rate is expressed as a function of duration of bright sunshine, air temperature, air humidity, and wind speed. The evaporation rate is converted to potential evapotranspiration rate from a short green crop cover never short of water. (Discussion by Harry F. Blaney and H. G. Wilm.)

Pennsylvania Department of Forests and Waters.

Forest and water research project, Delaware-Lehigh Experimental Forest: $\mathrm{Pa}$. Dept. Forests and Waters Rept. 3, 44 p., 1955.

Pennsyluania Topographic and Geologic Survey.

Ground water: Pa. Topog. and Geol. Survey Inf. Circ. 10, 10 p., 1958. 
Penrod, E. B.

(and Walton, W. W., and Terrell, D. V.). A method to describe soil temperature variation: Am. Soc. Civil Engineers Proc., v. 84, no. SM 1, Paper 1537, 21 p., 1958.

Variation of temperature with time for any soil depth is defined by an equation based on observed data. Calculated and observed temperatures are compared. (Discussion by D. C. Pearce, v. 84, no. SM 2, Paper 1657, p. 45, 1958; correction, v. 84, no. SM 4, Paper 1828, p. 21, 1958; and authors' closure, v. 85, no. SM 1, Paper 1951, p. 39-40, 1959.)

Pepper, JACK W.

Mississippi water rights law: Am. Water Works Assoc. Jour., v. 50, no. 8, p. 9971001, 1958.

The Mississippi Water Rights Act of 1956 is described.

\section{Perrey, Joseph I.}

1. Use of zoning principles in flood plain regulation: Am. Soc. Civil Engineers Proc., v. 82, no. HY 2, Paper 957, 10 p., 1956.

Zoning ordinances should prohibit all encroachments that would limit the required capacity of a floodway.

2. (and Corbett, D. M.). Hydrology of Indiana lakes: U.S. Geol. Survey WaterSupply Paper 1363, 347 p., 1956.

The following are discussed: Origin and gradual extinction of the lakes, surface temperatures and temperature profiles, evaporation, ice conditions, and stabilization of lakes. Basic data on lake levels and lake temperatures are given.

Perry, Robert.

Nebraska law affecting water resources: Am. Water Works Assoc. Jour., v. 50, no. 2 , p. 278-280, 1958.

Laws relating to ground water are discussed.

Peters, D. B.

(and Bartelli, Lindo J.). Soil moisture survey of some representative Illinois soil types: U.S. Dept. Agriculture, ARS 41-21, 40 p., 1958.

This report contains basic soil moisture characteristics of 30 soil types in 22 counties.

Petersen, Jack S.

(and Rohwer, Carl, and Albertson, Maurice L.). Effect of well screens on flow into wells: Am. Soc. Civil Engineers Trans., v. 120, p. 563-584, 1955.

A theoretical relation between loss of head and the characteristics of the well screen is developed. Screen coefficients were determined for specific screens. (Discussion by Wen-Hsiung Li, Arthur L. Collins, Mohammad Nazir and Nazir Ahmad, Matthew I. Rorabaugh, Dean F. Peterson, Jr., G. Cohen de Lara, and Gérard Tison, Jr.)

Peterson, Dean F., Jr. See also Petersen, J. S.; Zee, C. H.

Hydraulics of wells (in Ground water development-a symposium): Am. Soc. Civil Engineers Trans., v. 122, p. 502-517, 1957.

The development of theoretical well hydraulics and certain aspects of the application of these developments to practical problems are reviewed.

Peterson, Kendall R. See also Gilman, C. S.

Precipitation rate as a function of horizontal divergence: Monthly Weather Rev., v. 85 , no. 1 , p. $9-10,1957$.

Nomograms are presented showing rate of precipitation as a function of surface 
convergence and the 1,000-millibar temperature for 2 models-(1) pseudoadiabatically ascending air, assuming constant convergence with height, (2) same, but assuming a linear decrease of convergence with height to zero at 4.5 kilometers.

Peterson, William C. See also Hofmann, W.

Water resources summary for southern California, 1957: U.S. Geol. Survey Circ. 404, 19 p., 1958.

This is one of a series of annual reports.

Petitt, Ben M., JR.

(and Winslow, Allen G.). Geology and ground-water resources of Galveston County, Texas: U.S. Geol. Survey Water-Supply Paper 1416, 157 p., 1957.

Ground water was used almost entirely until 1948 when a surface-water supply was provided. Water-level changes, land subsidence, salt-water encroachment, and the need for additional study are covered.

Phelan, John T. See Haise, H. R., 2; Fox, R. L.

Philip, J. R. See also Hall, W. A., 3; Woodside, W.

1. (and de Vries, D. A.). Moisture movement in porous materials under temperature gradients: Am. Geophys. Union Trans., v. 38, p. 222-232, 1957.

A theory of moisture movement is developed which explains apparently discordant experimental information.

2. Evaporation and moisture and heat fields in the soil: Jour. Meteorology, v. 14, no. 4, p. 354-366, 1957.

A mathematical analysis, confined to steady conditions, suggests that desiccation of bare soil takes place in three phases: (1) so long as soil is sufficiently moist, evaporation is indistinguishable from that from a saturated surface, (2) at intermediate moisture contents, evaporation depends only on soil-moisture distribution, and (3) when surface layers are sufficiently dry, evaporation is sensitive to the heat flux in the soil. The theoretical developments provide a guide for future experimentation.

3. The theory of infiltration; 1 . The infiltration equation and its solution: Soil Sci., v. 83, no. 5, p. 345-357, 1957.

This paper describes the development of the infiltration equation, provides the numerical methods for its solution, and gives an illustrative solution.

4. The theory of infiltration; 2 . The profile of infinity: Soil Sci., v. 83 , no. 6, p. 435-448, 1957.

This second paper considers the problem of what happens during infiltration into a semi-infinite column as time approaches infinity.

5. The theory of infiltration; 3. Moisture profiles and relation to experiment: Soil Sci., v. 84, no. 2, p. 163-178, 1957.

In this third paper of the series, the basic assumptions of the mathematical analysis discussed in earlier papers are critically examined, and a simplification of the analysis is made for initially "dry" media. An investigation of the effect on the moisture profile during infiltration of the diffusivity and conductivity functions is made. From this the effects of soil texture and initial moisture content follow. 6. The theory of infiltration; 4 . Sorptivity and algebraic infiltration equations: Soil Sci., v. 84, no. 3, p. 257-264, 1957.

Work in the three preceding papers is used as the basis for a study of the available (generally empirical) infiltration equations used in applied hydrology. A new physical property of porous media, sorptivity, is proposed. 
7. The theory of infiltration; 5. The influence of the initial moisture content: Soil Sci., v. 84, no. 4, p. 329-339, 1957.

Previous papers in this series dealt with the mathematical analysis of infiltration. This paper treats in further detail the influence on infiltration of the initial moisture content of the soil.

8. The theory of infiltration; 6. Effect of depth of water over soil: Soil Sci., v. 85, no. 5, p. 278-286, 1958.

This sixth paper extends the mathematical analysis of the infiltration problem to the case where the depth of water over the soil is nonzero and so enables the effect of water depth on infiltration to be studied in some detail.

9. The theory of infiltration; 7: Soil Sci., v. 85, no. 6, p. 333-337, 1958.

This last paper of the series points out some implications of this approach to soil water problems and directions in which the work might be extended.

Philuips, H. Boyd. See Milligan, C. H., 2.

Picton, Walter L.

The water picture today: Water Well Jour., v. 10, no. 4, 1956.

A national summary of ground-water use and a projection to 1975 are given.

Pierce, L. T.

Estimating seasonal and short-term fluctuations in evapotranspiration from meadow crops: Am. Meteorol. Soc. Bull., v. 39, no. 2, p. 73-78, 1958.

Based on lysimeter data in Ohio, a revised curve for potential evapotranspiration was drawn, and corrections were developed to allow for the level of soil dryness and the stage of crop development.

Pierce, Robert S. See also Trimble, G. R., Jr., 4.

1. The effect of land use on the depth and duration of soil freezing in the Northeast: Eastern Snow Conf. Proc., v. 4, p. 12-16, 1956.

Data collected during two winters established the order of land-use types with respect to depth and duration of freezing.

2. (and Lull, Howard W. and Storey, Herbert C.). Influence of land use and forest condition on soil freezing and snow depth: Forest Sci., v. 4, no. 3, p. 246-263, 1958.

During two winters, biweekly observations of soil freezing and snow depths were made in six areas in the northeast. Results are given for frost depth, frost occurrence, accumulated frost depth, and snow depth for coniferous forest, hardwood forest, and open conditions.

Pierson, Royale K.

Range waterspreading as a range improvement practice: Jour. Range Management, v. 8, no. 4, p. 155-158, July 1955.

The objectives of waterspreading are the control of erosion and the conservation of moisture. Current studies and waterspreading methods are described.

Pillsbury, A. F. See also Isherwood, J. D.

(and Weeks, L. O., Spencer, J. R., and Reeve, R. C.). Discharge of tile drainage systems in an irrigated area of California: Am. Geophys. Union Trans., v. 37, p. 474-476, 1956.

Based on measurements of discharge from drains, the maximum discharge is related to length of tile.

Pitman, Arnold W.

The springs run again: Soil Conserv., v. 21, no. 7, p. 163-164, 1956.

Reforestation of hillsides restored spring flow in Vermont. 
Plate, E. J. See Liu, H. K., 2.

Pogorzelski, Henry A. See Chorley, R. J.

Poland, Joseph F. See also Davis, G. H.

1. (and Davis, G. H.). Subsidence of the land surface in the Tulare-Wasco (Delano) and Los Banos-Kettleman City area, San Joaquin Valley, California: Am. Geophys. Union Trans., v. 37, p. 287-296, 1956.

Subsidence of land surface has exceed 10 feet in 2 areas. The maximum rate approaches 1 foot per year. Decline in artesian pressure appears to be the major cause.

2. Land subsidence due to ground-water development: Am. Soc. Civil Engineers Proc., v. 84, no. IR 3, Paper 1774, 11 p., 1958.

Problems that have developed in subsidence areas in California are discussed.

Pollitt, Keith.

Status of ground-water studies in Canada: Royal Soc. Canada Trans., v. 51, ser. 3 , sec. 4 , p. 87-92, 1957.

History and present status are given.

Pomeroy, C. R. See Burgy, R. H., 3.

Poole, J. L. See Krieger, R. A.

Porges, Ralph.

Waste treatment in the Missouri River basin: Sewage and Indus. Wastes, v. 29, no. 11, p. 1215-1224, 1957.

A summary of 1956 inventory data of municipal and industrial waste facilities in the basin is presented.

Portman, Donald J.

Conductivity and length relationships in heat-flow transducer performance: Am. Geophys. Union Trans., v. 39, p. 1089-1094, 1958.

Errors in measuring heat conduction in soil will occur if the transducer has thermal properties different from those of the soil. An analysis of these errors is made. Results will be used to estimate error in measurements made during a field program.

Posey, Chesley J. See Einstein, H. A., 4; Kindsvater, C. E., 1; Matthes, G. H.; Powell, R. W.; Straub, L. G., 1.

Posz, H. M. See Allen, F. C.

PotTer, J. G.

Annual snowfall in eastern Canada: Eastern Snow Conf. Proc., v. 3, p. 36-47, 1955.

Percentage probabilities of seasonal and monthly snowfall limits are given.

Potter, LoRen D.

Yearly soil temperatures in eastern North Dakota: Ecology, v. 37, p. 62-70, 1956.

Soil temperatures at depths ranging from 1 inch to 6 feet were determined at 5 sites varying in cultural practice and snow cover.

PotTer, W. D.

1. The effect of nonrepresentative sampling on linear regressions as applied to runoff: Am. Geophys. Union Trans., v. 38, p. 333-340, 1957.

Based on linear multiple regressions, it is concluded that the precision of such an equation as an estimator depends more on the representativeness of the sample than on the sample size. (Discussions by N. J. Cochrane, J. L. McGuinness and D. L. Brakensiek, Manuel A. Benson; and author's closure, v. 39, p. 497-500, 1958.) 
2. Upper and lower frequency curves for peak rates of runoff: Am. Geophys. Union Trans., v. 39, p. 100-105, 1958.

Flood-frequency curves are defined by two straight lines designated as upper and lower frequency curves. A high degree of correlation is found between these curves for 10- and 50-year recurrence intervals. (Discussions by W. T. Wilson and D. M. Hershfield, Manuel A. Benson, R. Robinson Rowe; author's closure, v. 39, p. 1165-1170, 1958; and G. N. Alexander, Jour. Geophys. Research, v. 64, p. 132, 1959.)

Potrer, W. E.

Water resources of North Central States: Mil. Engineer, v. 47, no. 316, p. 85-89, 1955.

Resources of the area, water usage, industrial expansion, river development for navigation, and Missouri Basin multiple-purpose development are described.

Powell, James David. See Priddy, R. R., 1.

Powell, J. E. See also Paulson, Q. F.

Geology and ground-water resources of the Hankinson area, Richland County, North Dakota: N. Dak. Geol. Survey Ground-Water Studies, no. 25, 45 p., 1956.

Powell, Ralph W. See also Einstein, H. A., 4; Kindsvater, C. E., 2; Kuiper, E. (and Posey, C. J.). Tests of the flow of water in a smooth $\mathbf{V}$-shaped flume: Rocky Mtn. Hydraulic Lab. Rept., no. 21, 9 p., 1957.

Tests made to explore the effects of the variables influencing open-channel flow are described.

Powell, Sheppard T. See also Jenkins, D. S., 2.

Conversion of saline water into fresh water: Water Works Eng., v. 111, no. 10, 1958.

This is a nontechnical explanation.

Poweld, William J. See also Robinson, W. H.

1. (and Reade, H. L., and Scott, J. C.). Interim report on the geology and groundwater resources of Montgomery, Alabama, and vicinity: Ala. Geol. Survey Inf. Ser. 3, 108 p., 1957.

2. Ground-water resources of the San Luis Valley, Colorado, with a section on an inflow-outflow study of the area, by Philip B. Mutz: U.S. Geol. Survey Water-Supply Paper 1379, 284 p., 1958.

The investigation on which this report is based was concerned primarily with the determination of the probable quantity and quality of ground water that would be intercepted by a proposed closed-basin drain and with the determination of the ground-water conditions in an irrigated area.

Power, B. A. See Denison, P. J.

Powers, Harold J. See Morris, S. B., 1.

Pree, H. L.

(and Walker, W. H. and MacCary, L. M.). Geology and ground-water resources of the Paducah area, Kentucky: U.S. Geol. Survey Water-Supply Paper 1417, 214 p., 1957.

The area described is in the northeastern part of the Mississippi embayment of the Gulf Coastal Plain.

Prescott, Glenn C., JR.

Geology and ground-water resources of Graham County, Kansas: Kans. Geol, Survey Bull. 110, 98 p., 1955 . 
Geography and geology are described in general, and the occurrence, movement, utilization, and chemical character of the ground water are described in some detail.

Preston, Howard A.

(and Rydell, Louis E.). Coexistence of fish and dams: Am. Soc. Civil Engineers

Proc., v. 83, no. PO 5, Paper 1414, 21 p., 1957.

The conflict between maintenance of the Columbia River salmon fishery and the program for river development is discussed. (Discussion by M. H. Benson, v. 84, no. PO 2, Paper 1618, p. 7-8, 1958; and authors' closure, v. 84, no. PO 5, Paper 1830, p. 13-14, 1958.)

Price, Raymond.

1. (and Hoover, M. D.). Watershed management research in Arizona conducted by the Forest Service: Sept. 23, 1957, meeting Ariz. Watershed Program Proc., p. 5-10, 1957.

The report gives the highlights of countrywide and regional watershed management research and a brief description of current research in Arizona, by vegetation types.

2. Watershed management research in the Southwest: Am. Forestry Assoc., 33 p., 1958.

A review of the literature is presented.

Price, Wiluiam E., JR. See also Baker, J. A., 2.

Geology and ground-water resources of the Prestonsburg quadrangle, Kentucky:

U.S. Geol. Survey Water-Supply Paper 1359, 140 p., 1956.

This paper describes the geography, geology, and ground water of the area with emphasis on the water-bearing properties of the principal geologic formations. Many data are included.

Priddy, Richard Randall.

1. (and Crisler, Robert Malcolm, Jr., Sebren, Clarence Paul, Powell, James David, and Burford, Hugh). Sediments of Mississippi Sound and inshore waters: Miss. Geol. Survey Bull. 82, 54 p., 1955.

Investigations of inshore bottoms of parts of Mississippi Sound were made to determine the physical and chemical nature of the bottom materials with reference to the distribution, mortality, and abundance of oysters, shrimp, fish, and other organisms.

2. Fresh water strata of Mississippi as revealed by electrical log studies: Miss. Geol. Survey Bull. 83, 71 p., 1955.

The probable lateral distribution of subsurface fresh-water-bearing sands and their stratigraphic distribution were determined by a study of 500 electric logs. Descriptions of fresh-water aquifers are reported.

PRIDE, R. W.

Interim report on surface water resources of Baker County, Florida: Fla. Geol. Survey Inf. Circ., no. 20, 31 p., 1958.

Available data on the resources are summarized and evaluated. Factors which influence the design of shallow reservoirs on small streams are discussed.

Priest, Melville S. See Amein, A. M.

Prichard, D. W. See Todd, D. K., 4.

Prout, W. E.

Adsorption of radioactive wastes by Savannah River plant soil: Soil Sci., v. 86, no. 1, p. 13-17, 1958. 
Laboratory investigations defined the behavior of low-level radioactive wastes discharged to ground. The affects of cation concentration and acidity were determined. A typical application is discussed.

Prugh, Brron J.

1. Dewatering Miami's Biscayne aquifer: Am. Soc. Civil Engineers Proc., v. 83, no. SM 3, Paper 1299, 15 p., 1957.

Dewatering a deep excavation by use of wellpoints and the soils found in the excavation are described. (Discussion by W. Watters Pagon, v. 83, no. SM 4, Paper 1430, p. 33, 1957.)

2. Pressure relief system tames Florida boil: Civil Eng., v. 28, p. 46-48, Aug. 1958. An unexpected ground-water condition and the method of dewatering an excavation are described.

Pryor, Wayne A.

1. Groundwater geology in southern Illinois, a preliminary geologic report: Ill. Geol. Survey Circ. 212, 25 p., 1956.

This report summarizes the geologic conditions controlling the occurrence and availability of ground water and suggests efficient ways to obtain it. Likelihood of finding supplies ranges from poor in bedrock formation to excellent in sand and gravel deposits in major valley systems.

2. Quality of groundwater estimated from electric resistivity logs: Ill. Geol. Survey Circ. 215, 15 p., 1956.

Resistivity of ground water is estimated from electric well logs by a formula, and the resistivity is converted to sodium chloride solution equivalent. Graphs relate the sodium chloride solution equivalent and measured total solids in water.

3. Groundwater geology of White County, Illinois: Ill. Geol. Survey Rept. Inv. 196, 50 p., 1956.

\section{Public Administration Service.}

Public water policy in Tennessee: Public Adm. Service, 175 p., 1956.

A report to the Tennessee Water Policy Commission comprising Tennessee law relating to water, availability of water, withdrawal uses of water, uses requiring modification and control of streams, and a water policy for Tennessee.

Pumphrey, H. L.

Water-power resources in upper Carson River basin, California-Nevada: U.S. Geol. Survey Water-Supply Paper 1329-A, 29 p., 1955.

Potential power with storage is estimated for East and West Forks of Carson River. Development for power purposes only is not considered economically feasible.

Quackenbush, T. H.

(Renfro, G. M., Beauchamp, K. H., Lawhon, L. F., and Eley, G. W.). Conservation irrigation in humid areas: U.S. Dept. Agriculture Handb., no. 107, 52 p., 1957.

Principles and methods of irrigation designed for typical humid conditions are given.

Quesenberry, J. R. See Monson, O. W.

RAder, Earle M.

Salt water encroachment into well water in the Miami area: Am. Soc. Civil Engineers Proc., v. 81, Separate 669, 11 p., 1955.

Unwise drainage works partly depleted the ground-water supplies of the Miami area and led to intrusion of sea water. Projects have largely cured the trouble.

Radhakrishna, G. N. See Orlob, G. T., 1.

Ragotzkie, Robert A. See Bryson, R. A., 1. 
Raichlen, Frederic. See Ippen, A. T., 2.

Rainwater, Frank H. See Bradley, E., 1; Brown, D. W., 1; Colby, B. R., 2; Kohout, F. A.; Schreurs, R. L.; Sniegocki, R. T.

Rakprathum, Chumphon. See LaMoreaux, P. E., 2.

Rand, M. C. See also O'Connor, D. J.

Concepts of surface reaeration-a critical review: Sewage and Indus. Wastes, v. 29, no. 11, p. 1282-1300, 1957.

This paper examines various formulas for the effects of surface reaeration, and it evaluates the present status of our understanding of the subject.

Randolph, J. R. See Remson, I., 5.

Raney, W. A. See Allison, F. E.; Thorne, M. D.

RANTZ, S. W.

(and Stafford, H. M.). Floods of 1952 in California: U.S. Geol. Survey WaterSupply Paper 1260-D, p. 531-575, 1956.

This paper describes the flood of January 1952 in the South San Francisco Bay region and the snowmelt flood of 1952 in Kern River, Tulare Lake, and San Joaquin River basins.

Rao, B. Subba.

The water balance of the Ohio River Basin: Am. Meteorol. Soc. Bull., v. 39, no. 3, p. 153-154, 1958.

The total evapotranspiration from Ohio River basin for 1949 as computed from Thornthwaite's 1955 method is shown to be in good agreement with estimates based on hydrological considerations.

RAPP, J. R.

(and Visher, F. N., and Littleton, R. T.). Geology and ground-water resources of Goshen County, Wyoming, with a section on chemical quality of the ground water, by W. H. Durum: U.S. Geol. Survey Water-Supply Paper 1377, 145 p., 1957.

This 2,186-square mile area lies in southeastern Wyoming and is crossed by the North Platte River.

Rasmussen, Wrultam C. See also Andreasen, G. E.; Marine, I. W.

1. (and Slaughter, T. H., Meyer, R. R., Bennett, R. R., and Hulme, A. E.). The water resources of Somerset, Wicomico, and Worcester Counties: Md. Dept. Geology, Mines, and Water Resources Bull. 16, 533 p., 1955.

The report describes the ground and surface-water resources.

2. (and Groot, Johan J., Martin, Robert O. R., and McCarren, Edward F.). The water resources of northern Delaware, with a section on problems of water management, by Vaughn C. Behn: Del. Geol. Survey Bull., no. 6, 223 p., 1957.

This report evaluates the potential water resources, those available for use if maximum practicable storage capacity were constructed and if wells were spaced to obtain the optimum yield. The portion of New Castle County north of the Chesapeake and Delaware Canal is considered.

3. (and Slaughter, Turbit H., Hulme, Arthur E., and Murphy, J. J.). The water resources of Caroline, Dorchester, and Talbot Counties: Md. Dept. Geology, Mines, and Water Resources Bull. 18, 465 p., 1957.

The report contains sections on ground water, surface water, and salinity studies in estuaries of the Eastern Shore.

4. (and Groot, J. J., and Depman, A. J.). High-capacity test well developed at the 
Air Force Base, Dover, Delaware: Del. Geol. Survey Rept. Inv., no. 2, 36 p., 1958.

Results of the well tests indicate that the aquifer penetrated promises to become a valuable source of water in the Dover area.

5. (and Groot, J. J., and Beamer, N. H.). Wells for the observation of chloride and water levels in aquifers that cross the Chesapeake and Delaware canal:

Del. Geol. Survey Rept. Inv., no. 3, 22 p., 1958.

Three test wells were drilled near the canal banks to determine whether salt water from the canal entered the aquifer. Quality of water in the wells was fairly constant and did not correlate with variations of salinity in the canal. Enlargement of the canal may enhance the opportunity for salt-water encroachment.

Rattra, Maurice. See Morse, R. M.

RAUDSEPP, WALTER.

Runoff characteristics of the Columbia and Kootenay Rivers in British Columbia:

Western Snow Conf. Proc., p. 1-7, Apr. 1956.

Data are presented in graphical and tabular forms. Emphasis is on summer runoff.

RaUzi, Frank.

1. Water-infiltration studies in the Bighorn National Forest: Wyo. Univ. Agr. Expt. Sta. Mimeo. Circ., no. 58, 10 p., 1955.

Infiltration studies were conducted on 85 plots having each of the major soil typesand different kinds and amounts of plant cover. Simulated rainfall was applied with a mobile raindrop applicator.

2. Water-infiltration studies in the Bighorn National Forest: Wyo. Univ. Agr. Expt. Sta. Mimeo. Circ., no. 62, 7 p., 1956.

Water-infiltration rates were measured on 30 pasture plots of one soil type. Simulated rainfall was used.

Rawlins, G. S. See Bergen, S. W.

RaWN, A. M.

(and Bacon, Vinton W.). Philosophy of water pollution control in California: Sewage and Indus. Wastes, v. 27, no. 11, p. 1302-1309, 1955.

This paper gives (1) a brief description of the administrative organization, (2) discussion of basic concepts of water pollution control legislation, and (3) statement on how the water-pollution control program enters into proposals for the California Water Plan and for a State department of water.

RAY, P. R. See Hiser, H. W., 4.

RaY, William E.

(and Mondschein, Herman F.). A method of forecasting stages on flat rivers:

Am. Geophys. Union Trans., v. 38, p. 698-707, 1957.

A new approach used in conjunction with a modification of standard routing procedures was developed for Illinois River.

RAYMOND, J. R.

(and Bierschenk, W. H.). Hydrologic investigations at Hanford: Am. Geophys. Union Trans., v. 38, p. 724-729, 1957.

Records from several hundred wells show that discharge to ground of cooling water has raised the water table locally about 80 feet. Pumping test data are also given.

Rayner, Frank A.

1. Records of water-level measurements in Collingsworth, Hemphill, Roberts, and 
Wheeler Counties, Texas, 1937 through July 1958: Texas Board Water Engineers Bull. 5806, 23 p., 1958.

2. Records of water-level measurements in Jackson, Matagorda, and Wharton Counties, Texas, 1934 to April 1958: Texas Board Water Engineers Bull. 5804, 34 p., 1958.

ReAD, A. A. See Stone, J. F.

Reade, H. L. See Powell, W. J., 1.

REDField, Alfred C.

Water levels accompanying Atlantic Coast hurricanes (in Interaction of Sea and Atmosphere, a Group of Contributions, by A. C. Redfield, A. R. Miller, and others): Am. Meteorol. Soc. Meteorol. Mon., v. 2, no. 10, 1957.

The report describes the abnormal elevations of the sea surface accompanying hurricanes which cross the eastern coast of the United States from the sea. The study is based on data for Hurricanes Carol, Edna, and Hazel.

REE, W. O.

Hydraulic research: Soil Conserv., v. 22, no. 11, p. 246-249, 1957.

Research on the flow of water over agricultural lands and in grassed waterways is described.

REED, E. C.

(and Svoboda, R. F.). Nebraska deep well records: Nebr. Geol. Survey Bull. 17, 138 p., 1957.

REed, Edwin W.

(and Schoff, Stuart L., and Branson, Carl C.). Ground-water resources of Ottawa County, Oklahoma: Okla. Geol. Survey Bull. 72, 203 p., 1955.

The report describes geography, geology, water-bearing characteristics of geologic formations and their occurrence, and behavior and utilization of ground water.

REeder, H. O.

Ground water in Animas Valley, Hidalgo County, New Mexico: N. Mex. State Engineer Tech. Rept., no. 11, 101 p., 1957.

Ground water for irrigation is obtained from saturated sand and gravel beds. Depth to water table ranges from 15 to more than 200 feet and has increased yearly. Water is of suitable quality.

Reeve, R. C. See Allison, L. E.; Pillsbury, A. F.

Regan, Mark M. See Krutilla, J.

Reigner, Irvin C. See also Lull, H. W., 5.

1. (and McQuilkin, W. E., McNamara, E. F., and Lull, Howard W.). Report No. 3. Forest and water research project: Delaware-Lehigh Experimental Forest, Pa. Dept. Forests Waters, 44 p., 1956.

This is a progress report on cooperative watershed and scrub oak conversion studies. A tabulation of climatic, ground water, and streamflow data is given.

2. (and Byrnes, William R., and McNamara, E. F.). Forest watershed management research in the ridge and valley section of Pennsylvania: Northeastern Forest Expt. Sta., 7 p., 1958.

The report describes cooperative research being carried out at the Leading Ridge Experimental Watersheds by the Commonwealth, The Pennsylvania State University, and the Northeastern Forest Experiment Station of the U.S. Forest Service.

Remann, L. F. See Hamilton, E. L. 
Reinhart, Kenneth G. See also Carlson, C. A.; Lull, H. W., 2; Weitzman, S., 2. Calibration of five small forested watersheds: Am. Geophys. Union Trans., v. 39, p. 933-936, 1958.

Methods of calibrating streamflows from the watersheds are described. After calibration, four watersheds will be cut over and one will be used as a control. Effects of treatment on streamflow can then be measured.

\section{REMSON, IRWin.}

1. (and Fox, G. S.). Capillary losses from ground water: Am. Geophys. Union Trans., v. 36, p. 304-310, 1955.

A method is presented for estimating the discharge of ground water by evapotranspiration of water rising from the water table by capillarity. Essential agreement between theoretical and empirical profiles of capillary potential is found.

2. (and Lang, S. M.). A pumping-test method for the determination of specific yield: Am. Geophys. Union Trans., v. 36, p. 321-325, 1955.

Specific yield may be determined during the course of an equilibrium pumping test by comparing the volumes of water and unwatered material. Equations were developed theoretically and were tested using data in the literature.

3. (and Fox, G. S.). The displacement of calibration curves for electrical soilmoisture units: Am. Geophys. Union Trans., v. 36, p. 821-826, 1955.

Tests indicate the general unreliability of laboratory calibrations when compared with field calibrations of soil-moisture blocks. (Discussion by F. R. Dreibelbis, and authors' closure, v. 37, p. 497-499, 1956.)

4. (and van Hylckama, T. E. A.). Nomographs for the rapid analysis of aquifer tests: Am. Water Works Assoc. Jour., v. 48, no. 5, p. 511-516, 1956.

The nomographs described permit determinations of transmissibility and storage while the test data accumulate.

5. (and Randolph, J. R.). Application of statistical methods to the analysis of ground-water levels: Am. Geophys. Union Trans., v. 39, p. 75-83, 1958.

The time-series and functional-equation approaches are applied to New Jersey well records. Applicability of the results is shown.

Renfro, G. M. See Quackenbush, T. H.

Renfro, George M., Jr. See Law, W. P., Jr.

Renfro, Graham W.

(and Moore, Charlie M.). Sedimentation studies in the western Gulf States: Am. Soc. Civil Engineers Proc., v. 84, no. HY 5, Paper 1806, 15 p., 1958.

Results of Soil Conservation Service reservoir sedimentation surveys, methods used to determine sediment yields, and the effect of watershed-protection measures are presented.

Renner, F. G. See also Love, L. D., 1.

(and Love, L. D.). Management of water on western rangelands, in U.S. Department of Agriculture, Water: Yearbook of Agriculture 1955, p. 415-423.

Various conservation practices are used to keep the water on the land.

Renshaw, Clarence. See Fleming, R. J., 1.

Renshaw, Edward F.

Toward responsible government; An economic appraisal of federal investment in water resource programs: Chicago, Ill., Idyia Press, 164 p., 1957.

A critical study of the Federal programs for power, navigation, flood control, watershed protection, and irrigation is given. 
Retzer, J. L.

Physical environmental effects on beavers in the Colorado Rockies: Western Assoc. State Game and Fisheries Comm., 35th Ann. Conf. Proc., p. 279-287, 1955.

The report discusses physical suitability of mountain streams for beaver occupancy and the effect of beavers on the stability of those streams.

\section{Reynolds, Robin R.}

(and Kennedy, David V.). Water supply planning for multipurpose reservoir operation: Western Snow Conf. Proc., p. 1-4, Apr. 1957.

Rice, R. M. See Anderson, H. W., 6, 7.

RICH, L. R.

Relation of plant cover to watershed management: Ariz. Cattlelog, v. 11, no. 12, p. $34-36,1956$.

The report discusses the effect of reduction in plant cover under different grazing treatments upon surface runoff, seepage flow, total water yield, and soil loss.

RICH, LinviL G.

(and Jones, D. A.). Cost analysis of stream pollution surveys: Va. Polytech. Inst. Eng. Expt. Sta. Ser., no. 103, 30 p., 1955.

RICHARDs, L. A.

1. Retention and transmission of water in the soil, in U.S. Department of Agriculture, Water: Yearbook of Agriculture 1955, p. 144-151.

A description of the forces acting on water in the soil is given. Profiles representing static equilibrium, downward movement of water, and upward movement of water are illustrated and described.

2. (and Gardner, W. R., and Ogata, Gen). Physical processes determining water loss from soil: Soil. Sci. Soc. America Proc., v. 20, no. 3, p. 310-314, 1956.

Analysis of field observation lends encouragement to the view that flow and distribution of water in bare soil can be reduced to a problem in hydraulics providing certain other conditions are known.

3. (and Richards, S. J.). Soil moisture, in U.S. Department of Agriculture, Soil: Yearbook of Agriculture 1957, p. 49-60.

The efficient use of the available supply of soil moisture is usually a major aspect of soil management.

Richards, S. J. See Richards, L. A., 3.

Richardson, E. V. See Liu, H. K., 1.

Richardson, R. M. See also DeBuchananne, G. D.

Tidal fluctuations of water level observed in wells in East Tennessee: Am. Geophys.

Union Trans., v. 37, p. 461-462, 1956.

Semidiurnal water-level fluctuations of tidal period have been observed in wells completed in limestone.

Richheimer, Clarence E. See Smith, D. B., 1, 2, 3.

Richter, Raymond C. See Banks, H. O., 1.

Riddick, Thomas M.

Forced eirculation of large bodies of water: Am. Soc. Civil Engineers Proc., v. 84, no. SA 4, Paper 1703, 21 p., 1958.

Use of a floating aerator in a reservoir resulted in breaking stratification and oxidizing and precipitating iron and manganese. (Discussion by C. H. J. Hull, v. 85, no. SA 1, Paper 1921, p. 21-23, 1959.) 


\section{Ridgeway, Marian E.}

The Missouri Basin's Pick-Sloan Plan: Urbana, Ill. Univ. Press, 403 p., 1955.

This study reveals the policy formulation process by which the legislation known as the Pick-Sloan Plan was developed and some of the happenings which resulted after enactment of the plan.

Rigard, M. Jean. See Stevens, J. C.

Rigby, Malcolm. See Nupen, W.

RIgGs, H. C. See Kuiper, E.; Paulhus, J. L. H.; Zoller, J. H.

Riley, B. G. See Schaller, F. W.

Rima, Donali R.

Ground-water resources of the Lansdale area, Pennsylvania: Pa. Topog. and Geol. Survey Prog. Rept. 146, 24 p., 1955.

ROARK, CAL L.

(and Lester, R. I.). Ponds don't have to go bad: Farm and Ranch, v. 88, no. 3, p. 19, Mar. 14, 1958.

Methods are presented to help establish permanent vegetative cover on dams.

Roberson, John A. See Ingerson, I. M.

RoBerts, C. M.

(and Widman, L. E., and Brown, P. N.). Water resources of the Indianapolis area, Indiana: U.S. Geol. Survey Circ. 366, 45 p., 1955.

This report describes the water resources and present water use.

ROBERTS, K. L.

Water unlimited: Garden City, N.Y., Doubleday and Co., 285 p., 1957.

The story of the achievements of a corporation formed in 1950 to direct and develop Henry Gross' alleged ability to find water with a dowsing rod.

Roвerts, W. J. See also Hudson, H. E., Jr.

Evaporation suppression from water surfaces: Am. Geophys. Union Trans., v. 38, p. 740-744, 1957.

A discussion of the use of monomolecular films and the results of research by Illinois State Water Survey are given.

Roberts, Walter OrR.

Sun clouds and rain clouds: Sci. Am. v. 196, no. 4, p. 138-148, 1957.

The earth intercepts, at average intervals of a month, a swarm of corpuscles ejected by the sun. There is new evidence that these corpuscles affect the weather.

Robertson, David A., Jr. See Cleary, E. J., 2.

Robertson, George W.

(and Holmes, R. M.). Estimating irrigation water requirements from meteorological data: Canada Dept. Agriculture, Experimental Farms Service, 19 p., 1956.

The black Bellani plate atmometer, when exposed to sunshine and the free flow of air, shows variations of latent evaporation that agree closely with variations of potential evapotranspiration as computed by Penman's equation. A meteorological budget system may be developed for defining an irrigation schedule.

Robertson, James M. See Chow, V. T., 2; Straub, L. G., 1. 


\section{RoBinove, C. J.}

(and Langford, R. H., and Brookhart, J. W.). Saline-water resources of North

Dakota: U.S. Geol. Survey Water-Supply Paper 1428, 72 p., 1958.

The report describes the principal saline-water aquifers and surface-water bodies, and gives available analyses.

Robinson, Art. See Ulrich, A. A.

Robinson, August R., JR.

1. Seepage measurement and its relation to drainage and canal lining programs: Jour. Soil and Water Conserv., v. 11, no. 2, p. 79-81, 1956.

Methods of measuring seepage in the field are described.

2. (and Rohwer, Carl). Measurement of canal seepage: Am. Soc. Civil Engineers Trans., v. 122, p. 347-363, 1957.

Existing methods of measuring seepage have been investigated, and a method of analysis was developed for using the well permeameter test results in forecasting seepage. (Discussion by Raymond A. Hill, Dean C. Muckel, Calvin C. Warnick, N. Szalay, and Cyril W. Lauritzen.)

3. Parshall measuring flumes of small sizes: Colo. A. and M. Coll., Agr. Expt. Sta. Tech. Bull. 61, 12 p., Jan. 1957.

The design allows use of standard calibration curves. Construction details of the flumes are given.

Robinson, T. W.

Phreatophytes: U.S. Geol. Survey Water-Supply Paper 1423, 84 p., 1958.

This is a comprehensive report on phreatophytes; and their effects on water resources.

Robinson, W. H. See also Lang, J. W.

(and Powell, W. J., and Brown, Eugene). Water resources of the Mobile area, Alabama: U.S. Geol. Survey Circ. 373, 45 p., 1956.

Water resources and present water utilization are described.

Rockwood, David M. See also Ellis, J. D.

1. Columbia Basin streamflow routing by computer: Am. Soc. Civil Engineers

Proc., v. 84, no. WW 5, Paper 1874, 15 p., 1958.

A new routing technique, made possible by use of a digital computer, is described. (Discussion by Willard M. Snyder, v. 85, no. WW 2, Paper 2078, p. 145-155, 1959; and author's closure, v. 85, no. WW 3, Paper 2184, p. 285-286, 1959.)

2. Columbia Basin streamflow routing by computer: Civil Eng., v. 28, p. 66-69, May 1958.

A new procedure for streamflow forecasting is developed. The procedure utilizes a new technique for streamflow routing which is made practical by the capabilities of an electronic computer.

Rodebush, Worth H. See Buswell, A. M., 1, 2.

Rohwer, Carl. See Blaney, H. F., 2, 5; Petersen, J. S.; Robinson, A. R., Jr., 2. Rolfe, B. N. See Hadley, R. F.

Roller, E. M. See Allison, F. E.

Rorabaugh, Matthew I. See also Petersen, J. S.

1. Prediction of ground-water levels on basis of rainfall and temperature correlations: Am. Geophys. Union Trans., v. 37, p. 436-141, 1956.

The annual change in water level is correlated with winter precipitation, winter temperature, and loss of water to Ohio River. 
2. Ground water in northeastern Louisville, Kentucky, with reference to induced infiltration: U.S. Geol. Survey Water-Supply Paper 1360-B, p. 101-169, 1956.

This paper reports on a detailed investigation of the ground-water resources of a 3 -square-mile area along the Ohio River. The theory of induced infiltration is given, and the maximum infiltration supplies that could be developed under various conditions are estimated.

Rosa, J. M.

1. Forest snowmelt and spring floods: Jour. Forestry, v. 54, p. 231-235, Apr. 1956.

A hydrograph is estimated from basin and climatic parameters. The method may permit estimating the probable effect of forests on spring floods.

2. (and Croft, A. R.). Water yield and public land management: Jour. Soil and Water Conserv., v. 11, no. 4, p. 157-161, 1956.

Available records do not show any significant change in total annual streamflow which could be attributed to land-use changes. Examples are taken from Utah and adjacent States.

Rose, H. Glen.

(and Smith, H. F.). Particles and permeability: Water Well Jour., v. 11, no. 3, 1957.

A method of determining permeability and specific capacity from effective grain size is given.

Roseberry, C. R.

Gross and groundwater: Water Well Jour., v. 9, no. 2, 1955.

Henry Gross and Kenneth Roberts witch for water at Albany, N.Y.

Rosenshein, Joseph S.

Ground-water resources of Tippecanoe County, Indiana: Ind. Div. Water Resources Bull., no. 8, 38 p., 1958.

Rosenthal, Barnet L.

Radioactive rainfall found in Massachusetts: Water Works Eng., v. 108, no. 3, p. 224, 1955.

High radioactivity was found in rainfalls and in stream water 2 days after a nuclear detonation in Nevada. The reduction in radioactivity with time is presented.

Rothrock, E. P.

Ground water reservoirs near Aberdeen, South Dakota: S. Dak. Geol. Survey Rept. Inv., no. 78, 47 p., 1955.

Rouse, Hunter. See also Chow, V. T., 2; Kandaswamy, P. K.

(and Ince, Simon). History of hydraulics: Iowa Inst. Hydraulic Research, 269 p., 1957.

The report covers the period from antiquity to the present.

Rowe, P. B. See also Hopkins, W., 3.

1. Effects of the forest floor on disposition of rainfall in pine stands: Jour. Forestry, v. 53, p. 342-348, May 1955.

The influence of the forest floor on evaporation, runoff, and percolation was determined from studies in a pine forest.

2. Possible ways of increasing streamflow yield of the Salt River drainage by watershed modification in pt. 2, Recovering rainfall: Ariz. Watershed Program, p. 197-207, 1956.

Rowe discusses means of increasing streamflow without regard to the effects that possible land treatments may have upon the land, floods, or soil erosion. 
3. Research by the U.S. Forest Service, San Dimas Research Center: Conf. Sediment Problems Calif., Comm. Research Water Resources, Calif. Univ. Proc., p. 23-25, 1956.

The report describes erosion problems of southern California mountain watersheds, erosion research at the San Dimas Research Center, and research needed.

4. (and Colman, E. A.). Uses of soil-vegetation survey information in watershed management: Soil Sci. Soc. America Proc., v. 21, no. 1, p. 112-114, 1957.

Kinds of information required, need for improved methods of measuring hydrologic characteristics of soils, and a description of three wild land soils in California are given.

5. Tests of applied watershed management to increase water yield-San Dimas Experimental Forest: Ariz. Watershed Program Proc. 2d Ann. Mtg., p. 59-62, 1958.

The report discusses soil moisture--brush conversion plot results and applied wateryield studies in Big Dalton Canyon.

Rowe, Paul P.

Difference approximations to partial derivatives for uneven spacing in the network:

Am. Geophys. Union Trans., v. 36, p. 995-1008, 1955.

Difference expressions are developed, which do not require even spacing in the network. The errors involved in replacing the derivatives with three difference expressions are investigated.

Rowe, R. Robinson. See also Potter, W. D., 2.

(and Long, Gordon L., and Royce, Thomas C.). Flood frequency by regional synthesis: Am. Geophys. Union Trans., v. 38, p. 879-884, 1957.

Long records for an average stream for a region have been synthesized so as to derive factors for extrapolation of frequency curves for each stream in the region. Reliability of the method is tested. (Discussions by Manuel A. Benson, Ray K. Linsley, and David M. Hershfield; and authors' closure, v. 39, p. 974-980, 1958.)

Rowland, JoHN B.

Features shown on topographic maps: U.S. Geol. Survey Circ. 368, 23 p., 1955. This paper describes the three main categories of map information and the methods by which they are shown.

Royce, Thomas C. See Rowe, R. R.

Rubey, HaRRy.

Irrigation-drainage-climatology for flat humid land: Mo. Univ. Bull., v. 59, no. 15, 10 p., 1957.

Ruggles, F. H. See Simpson, E. S.

Ruhe, Robert V. See Smith, G. D.

Runkles, J. R. See Shaw, R. H.

Rupani, Navinchandra L. See Chien, N., 1; Stall, J. B.

Russeli, M. B.

(and Danielson, R. E.). Time and depth patterns of water use by corn: Agronomy Jour., v. 48, no. 4, p. 163-165, 1956.

Corn utilized water to a depth of 5 feet. Rainfall and irrigation affected the soil moisture profile to a depth of only 2 feet. Rate of water disappearance from corn plots exceeded substantially the open-pan evaporation rate during the period of rapid corn development when sufficient soil moisture was present. 
Ruth, Robert H. See Dyrness, C. T.

Rydell, Louis E. See Preston, H. A.

SaAltink, H. J. See Clinch, R. L.

SAlmond, G. R.

(and Croft, A. R.). The management of public watersheds, in U.S. Department of Agriculture, Water: Yearbook of Agriculture 1955, p. 191-198.

The extent, administration, and methods of management are discussed.

SAlter, Robert M.

(and Kelley, Omer J.). Research, a key to the future, in U.S. Department of Agriculture, Water: Yearbook of Agriculture 1955, p. 694-700.

Research must solve the problems of water that pertain to all agricultural lands, problems that are related to crop production, and problems on watersheds.

Salzman, Michael $\mathrm{H}$.

Where does groundwater come from?: Eng. News-Rec., v. 159, no. 21, p. 32-33, Nov. 28, 1957.

A brief, general description of sources is given.

Sammons, W. H. See Hershfield, D. M.

Sandals, KIrk M. See Steele, H. A.

Sanford, Thomas H., JR.

Interim report on ground-water studies in the Huntsville area, Alabama, to Feb. 1957: Ala. Geol. Survey Inf. Ser. 9, 131 p., 1957.

Sargent, Lestie, Jr. See Trimble, G. R., Jr., 3.

Sarpkaya, Turgut. See also Kindsvater, C. E., 2 ; Li, W. H., 1.

Oscillatory gravity waves in flowing water: Am. Soc. Civil Engineers Trans., v. 122 , p. 564-586, 1957.

The purposes of this paper are to define conditions of stability of progressive and oscillatory gravity waves and to evaluate the effect on wave propagation of viscous shear, turbulent mixing shear, and nonuniform velocity distribution. Results of the laboratory and theoretical investigations are compared.

Sartz, Richard S. See also Trimble, G. R., Jr., 4.

1. (and Trimble, George R., Jr.). Snow storage and melt in a northern hardwoods forest: Jour. Forestry, v. 54, p. 499-502, Aug. 1956.

Observations of snow depths, water contents, and snow densities on experimental plots in New Hampshire indicate significant differences between open and forested areas. The pattern of snowmelt is related to shading and this suggests the possibility of increasing water yield by selective cutting.

2. Snow and frost measurements in a watershed management research program:

Eastern Snow Conf. Proc., v. 4, p. 97-103, 1957.

Measurements on a 40-acre plot in New Hampshire are described.

3. Influence of land use on time of soil freezing and thawing in the Northeast: Jour.

Forestry, v. 55, p. 716-718, Oct. 1957.

Based on observations on plots in five areas, it was found (1) that open-land soils froze before softwood forest soils, (2) that softwood forest soils froze before hardwood forest soils, (3) that open-land soils thawed before softwood forest soils but after hardwood forest soils.

4. Snow and frost measurements in a watershed-management research program:

U.S. Forest Service, Northeastern Forest Expt. Sta. Paper 96, 9 p., 1957. 
Results of $1955-56$ studies are described.

SASMAN, RoBERT T.

The water-level problem at Crystal Lake, McHenry County: Ill. Water Survey Rept. Inv. 32, 27 p., 1957.

Water-level fluctuations of as much as 4 feet are related to shallow ground-water movement, precipitation, and evaporation. Methods of stabilizing the lake level are considered.

Satterwhite, L. E. See Lemon, E. R., 2.

Savage, Rudolph P.

Wave run-up on roughened and permeable slopes: Am. Soc. Civil Engineers Proc., v. 84, no. WW 3, Paper 1640, 38 p., 1958.

Runup on various beach slopes is related to wave steepness, slope roughness, and slope permeability on the basis of results of laboratory tests.

Scalapino, Ralph A.

Artificial recharge of ground water reservoirs: Am. Water Works Assoc. Jour., v. 47 , no. 3 , p. 230-234, 1955.

Practices in the southwestern United States are described.

Scarcia, Glenn. See Eddards, M. L.

ScEva, JACK E.

Geology and ground-water resources of Kitsap County, Washington: U.S. Geol.

Survey Water-Supply Paper 1413, 178 p., 1957.

Kitsap County oceupies a peninsula and several islands in the Puget Sound waterways in the central part of western Washington.

Schafer, Francis T. See Zoller, J. H.

Schaller, F. W.

(and Riley, B. G.). The water problem in Iowa: Iowa Agr. Expt. Sta. Bull. P 122, 24 p., 1957.

SCHEIDEgGER, A. E.

1. The physics of flow through porous media: New York, MacMillan Co., 231 p., 1957.

The general physical aspects of the phenomenon are described theoretically, and solutions to basic problems given by examples. Properties of porous media (both isotropic and anisotropic) and the behavior of fluids are discussed. Permeability and multiple-phase flow are treated extensively.

2. Typical solutions of the differential equations of statistical theories of flow through porous media: Am. Geophys. Union Trans., v. 39, p. 929-932, 1958.

Methods of describing the miscible displacement process in porous media are modified to allow for autocorrelation. The effect of considering autocorrelation is shown.

Schiff, Leonard. See also Burgy, R. H., 1; Muckel, D. C., 2.

1. The status of water spreading for ground-water replenishment: Am. Geophys.

Union Trans., v. 36, p. 1009-1020, 1955.

Methods of spreading water on land surfaces are reviewed, and some results are given.

2. (and Bliss, Eldred S., and Johnson, Curtis E.). Spreading water to conserve it: Soil Conserv., v. 20, no. 12, p. 267-272, 1955.

The problem of underground water storage is discussed. 
3. Proceedings, Conference on Water Spreading for Ground-Water Recharge, Davis, California, March 19, 1957: Calif. Univ. Comm. Research Water Resources, 80 p., 1957.

4. (and Johnson, Curtis E.). Some methods of alleviating surface clogging in water spreading with emphasis on filters: Am. Geophys. Union Trans., v. 39, p. 292-297, 1958.

Methods are described (1) for preventing clogging of soil pores when spreading water on soil surfaces for aquifer recharge, and (2) for removing clogging materials. Past experimental work is reviewed, and the use of filters is discussed.

Schipf, R. G. See Billingsley, G. A.

Schlange R, S. O.

(and Brookhart, J. W.). Geology and water resources of Falalop Island, Ulithi Atoll, western Caroline Islands: Am. Jour. Sci., v. 253, no. 10, p. 553-573, 1955.

Rainfall percolates readily to the water table where fresh water floats on top of sea water. A small supply of potable water can be obtained from wells.

Schlommer, Robert W. See also Hiatt, W. E.

An empirical index of seasonal variation of intense precipitation over large areas:

Monthly Weather Rev., v. 83, no. 12, p. 302-313, 1955.

The report presents a series of maps for the east half of the United States showing the percent of maximum value of seasonal variation of precipitation over large areas and an index of intense precipitation.

SchmidT, James J.

The water resources of Ross County, Ohio: Ohio Div. Water Inf. Circ. 4, 25 p., 1955.

Schmidt, Robert W. See Vaughn, J. C.

Schnader, William A.

(and Greeley, Samuel A.). The Delaware River water problem, discussion of a difficult allocation decision: Eng. News-Rec., v. 154, no. 2, p. 35-40, Jan. 13, 1955.

Problems in apportionment of the river water are described.

Schneider, Robert. See also Straka, G. C.

Correlation of ground water levels and air temperatures in the winter and spring in Minnesota: Minn. Div. Waters Tech. Paper, no. 1, 17 p., 1958.

Hydrographs of two wells indicate that the water level declines when air temperature is below $32^{\circ} \mathrm{F}$ but that it increases during the spring as does the temperature. Correlation is used in the geological, not the statistical sense.

Schneider, WrLliam J.

Relation of geology to streamflow in the upper Little Miami basin: Ohio Jour. Sci., v. 57 , no. 1 , p. 11-14, 1957.

The variation in low-flow indices for streams is controlled principally by the variation in the glacial geology of the basins.

Schoff, Stuart L. See Reed, E. W.

SchoNeR, R. W.

(and Molansky, S.). Rainfall associated with hurricanes: U.S. Weather Bur., Natl. Hurricane Research Proj. Rept., no. 3, 305 p., 1956.

A listing of major storms in the North Atlantic, South Atlantic, and Gulf Coast regions. Most of the entries consist of a short text summary of the meteorological situation and isohyetal maps of the total-storm rainfall and of the large 24-hour 
amounts. Maximum depth-area-duration values are tabulated from "Storm Rainfall in United States," Corps of Engineers.

Schoppenhorst, Charles E.

Floods of June-July 1957 in Indiana: U.S. Geol. Survey Circ. 407, 32 p., 1958.

Flood stages and discharges are given.

Schosser, Frank A. See Helwick, C. H.

Schrader, W. D. See Bertoni, J.

SchreURS, R. L.

Geology and ground-water resources of Buffalo County and adjacent areas, Nebraska, with a section on chemical quality of the ground water, by Frank $\mathbf{H}$.

Rainwater: U.S. Geol. Survey Water-Supply Paper 1358, 175 p., 1956.

The geography and geology of the area, the ground-water movement, fluctuations of the water table, ground-water recharge and discharge, and present use and chemical quality of ground water are given.

SchroEder, K. B.

(and Hembree, C. H.). Application of the modified Einstein procedure for computation of total sediment load: Am. Geophys. Union Trans., v. 37, p. 197$212,1956$.

A method that enables good estimates to be made of total sediment load has been tested with data from several western streams. (Discussions by Emmett M. Laursen and Lloyd C. Fowler, and authors' closure, v. 38, p. 768-773, 1957.)

\section{Schuetz, J.}

(and Stout, G. E.). RHI radar observation of a tornado: Ill. Water Survey Circ. 70, p. 591-595, 1958.

Preceding the development of a tornado at the ground, a fingerline projection developed on the PPI in the southwest corner of an echo. The tornado occurred simultaneously with the merging of a new cell with the finger.

Schuleen, E. T. See Langbein, W. B., 1.

Schuleen, Emil P. See also Gilcrest, B. R.

Flood plain zoning as supplement to flood control: Am. Soc. Civil Engineers Proc. v. 82, no. HY 2, Paper 954, 6 p., 1956.

The limitations and ineffectiveness of various types of flood-control measures are such that flood-plain zoning is a needed supplement.

Schulman, Edmund.

Dendroclimatic changes in semiarid America: Tucson, Ariz. Univ. Press, 142 p., 1956.

The report describes development of the longest significant chronologies of year-byyear rainfall and riverflow available from the annual growth-rings of the oldest suitable trees.

Schultz, A. M. See Biswell, H. H.

Schultz, Edward A.

1. Sediment sampling in tidal waterways: Am. Soc. Civil Engineers Trans., v. 120, p. $687-696,1955$.

This paper reports on a series of studies made in Charleston, S.C. harbor to determine (1) accuracy of sediment-sampling procedures and (2) the value of performing only a few, rather than many, operations. 
2. (and Simmons, H. B.). Fresh water-salt water density currents, a major cause of siltation in estuaries: U.S. Army Corps Engineers Comm. Tidal Hydraulics, Tech. Bull., no. 2, 28 p., 1957.

Schumm, Stanley A. See also Langbein, W. B., 3.

1. The role of creep and rainwash on the retreat of badland slopes: Am. Jour. Sci., v. 254, no. 11, p. 693-706, 1956.

Two types of topography have developed near Wall, S. Dak. The formation of one is attributed to rainwash erosion. Erosion ranging from 0.8 to 1.5 inches under 32 inches of rainfall during a $251 / 2$-month period was measured.

2. Evolution of drainage systems and slopes in badlands at Perth Amboy, New Jersey: Geol. Soc. America Bull., v. 67, p. 597-646, 1956.

This is a report on a detailed study of geomorphic processes and landforms.

3. (and Hadley, R. F.). Arroyos and the semiarid cycle of erosion: Am. Jour. Sci., v. 255, no. 3, p. 161-174, 1957.

Data obtained on small drainage basins in Wyoming and New Mexico suggest that the origin and location of discontinuous gullies within these valleys may be dependent on the gradient of the valley fill, and that any hypothesis of arroyo cutting must take into consideration the character of the drainage basin itself.

Schuppert, K. See Selleck, G. W.

Schwab, Glenn O. See Frevert, R. K.

Schwalen, H. C.

(and Shaw, R. J.). Ground water supplies of Santa Cruz Valley of southern Arizona between Rillito Station and the international boundary: Ariz. Agr. Expt. Sta. Bull., 119 p., 1957.

This report includes a condensation of data collected and results of ground-water studies made in the area over a period of years. A history of the development of ground water, changes in ground-water table, and a touch of hydrology are given.

Schwob, Carl E.

Pollution-a growing problem of a growing nation, in U.S. Department of Agriculture, Water: Yearbook of Agriculture 1955, p. 636-643.

Sources, control, sewage treatment, laws, and Federal and community responsibilities are covered.

Schwob, Harlan H.

Low-flow characteristics of Iowa streams: Iowa Nat. Resources Council Bull., no. 9, 111 p., 1958.

This report presents results of a study of the occurrence of low flow on Iowa's interior streams.

Scott, HaRold A.

Water control in central and southern Florida: Am. Soc. Civil Engineers Trans., v. 122, p. 211-227, 1957.

The report contains data on the hydrology of the areas.

Scotт, John C. See also Powell, W. J., 1.

Ground-water resources of Lowndes County, Alabama-a reconnaissance report: Ala. Geol. Survey Inf. Ser. 6, 80 p., 1957.

Scotт, R. C. See Barker, F. B., 1; Crosthwaite, E. G., 1.

Scott, RaLPh H. See also Lueck, B. F.

(and Wisniewski, T. F., Lueck, B. F., and Wiley, A. J.). Aeration of stream flow at power turbines: Sewage and Indus. Wastes, v. 30, no. 12, p. 1496-1505, 1958. 
The effects on stream aeration and on turbine operation of admitting air to a turbine are described.

ScotT, V. H.

1. Relative infiltration rates of burned and unburned upland soils: Am. Geophys. Union Trans., v. 37, p. 67-69, 1956.

Burned soils had higher rates following a fire. One year later the results were similar with one exception.

2. (and Burgy, R. H.). Effects of heat and brush burning on the physical properties of certain upland soils that influence infiltration: Soil Sci., v. 82, no. 1, p. 63-70, 1956.

The results reported indicate that heat and brush burning on Hugo soil resulted in measurable changes in aggregation and permeability in the surface layers, and consequently increases in infiltration rates. Less pronounced effects were found on Aiken soil.

Scruton, G. H. See Cavadias, G. S., 1.

SEARCY, J. K.

Floods in Missouri, magnitude and frequency: U.S. Geol. Survey Circ. 370, 126 p., 1955.

Two curves are given from which a flood-frequency relation may be obtained for a site anywhere in the State. Records of annual floods are included.

Sebren, Clarence Padl. See Priddy, R. R., 1.

SeigWorth, Kenneth J.

(and Olson, Earl F.). Infiltration changes resulting from forest protection and management: Jour. Soil and Water Conserv., v. 12, no. 6, p. 279-282, 1957.

Fire protection, grazing control, and reforestation as provided on TVA controlled watersheds have increased the infiltration capacities of the soils.

Selim, M. A. See Hargreaves, G. H.

Selkregg, Lidia F.

(and Kempton, John P.). Groundwater geology in east-central Illinois-a preliminary geologic report: Ill. Geol. Survey Circ. 248, 36 p., 1958.

Probabilities for developing usable ground-water supplies range from poor to excellent. Ground-water principles, geologic factors that control the availability of ground water, and methods of developing ground-water supplies are treated. Maps show the areal distribution and water-yielding character of the aquifers.

Selleck, G. W.

(and Schuppert, K.). Some aspects of microclimate in a pine forest and in an adjacent prairie: Ecology, v. 38, p. 650-653, 1957.

Evaporation from soil in pans in the open was four times that from pans in the forest. The experiment was designed to test the Lowry method of measuring water loss from the soil.

Semonin, R. G. See Huff, F. A., 8.

Senn, H. V. See Hiser, H. W., 2.

Servisi, James A.

Project Glacier, an improved method of recording a glacial advance: Photogramm.

Eng., v. 23, no. 3, p. 550-552, 1957.

Use of terrestrial photogrammetry is described. 
Setter, Lloyd R.

1. (and Goldin, Abraham S.). Measurement of low-level radioactivity in water: Am. Water Works Assoc. Jour., v. 48, no. 11, p. 1373-1379, 1956.

One reliable method is described.

2. (and Goldin, A. S.). Radioactive fallout in surface waters: Indus. and Eng. Chem., v. 48, no. 2, p. 251-255, 1956.

The 1954 radioactive rainout in Cincinnati, Ohio, was about 0.5 microcuries per square meter. Nearly half of the radioactivity was associated with filterable solids, and only 4 percent of the rain activity was found in pond water.

3. (and Straub, Conrad P.). The distribution of radioactivity from rain: Am. Geophys. Union Trans., v. 39, p. 451-458, 1958.

Without precipitation there is little fallout. Over 90 percent of the suspended and dissolved fallout becomes associated with soil and vegetation rather than appearing in surface waters. The fallout at Cincinnati, Ohio, is estimated.

Shahori, Ami. See Krimgold, D. B.

Shanks, R. E. See Drew, J. V.

Shannon, John W. See Blaney, H. F., 5 .

Sharp, Robert P.

1. Glaciers in the Arctic: Arctic, v. 9, nos. 1 and 2, p. 78-117, 1956.

The size, nature, and distribution of arctic and subarctic glaciers are treated descriptively in this compilation.

2. The latest major advance of Malaspina Glacier, Alaska: Geog. Rev., v. 48, no. 1, p. 16-26, 1958.

Field data indicate that the latest major advance overrode a mature spruce forest $200 \pm 50$ years ago.

SHaw, E. W.

Snow research in the Colorado alpine: Prism, Colo. State Univ., p. 11-12, Winter 1958.

Popular photostory on the station's alpine research.

Shaw, R. H. See also Thom, H. C. S., 2.

(and Runkles, J. R.). Soil moisture and water utilization in Iowa: Agronomy Jour., v. 48, no. 7, p. 313-318, 1956.

Average water loss per day by runoff, percolation, and evapotranspiration was 0.04 to 0.05 inch in winter and 0.18 to 0.20 inch in summer from soil samples. Change in soil moisture throughout the year was defined.

Shaw, R. J. See Schwalen, H. C.

Shaw, Samuel P.

(and Fredine, C. Gordon). Wetlands of the United States: U.S. Fish and Wildlife Service Circ. 39, 67 p., 1956.

Wetlands are classified in 20 types, and the area of each in the United States is shown. Purpose of the report is to point out the relative values of the different types to waterfowl.

Shea, Paul H.

Unusual foundation conditions in the Everglades: Am. Soc. Civil Engineers Trans., v. 120 , p. 92-102, 1955.

This paper describes high rates of flow in permeable limestone.

Sheaffer, John R. See White, G. F., 2. 
Shelton, M. J.

Need for planning in utilizing water resources: Am. Water Works Assoc. Jour., v. 49 , no. 8, p. 993-1000, 1957.

A brief history of planning in California, a statement of new problems, and the need for State action and group cooperation are given.

Shen, Richard T. See Herndon, L. W.

Shepherdson, IsaAc. See Witzigman, F. S., 1.

Sherman, Irving. See Johnson, R. W.

SHERROD, JoHN, JR.

1. A review of the first 10,000 abstracts prepared by the SIPRE bibliography project: Western Snow Conf. Proc., p. 2-3, Apr. 1955.

The project of the Snow, Ice, and Permafrost Research Establishment, U.S. Army Corps of Engineers is described.

2. A review of the first 15,000 abstracts prepared by the SIPRE bibliography project: Eastern Snow Conf. Proc., v. 4, p. 122, 1957.

Bibliography is being prepared by Snow, Ice, and Permafrost Research Establishment, U.S. Army Corps of Engineers.

Shiн, Yang-Ch'Eng.

American water resources administration: New York, Bookman Associates, v. 2, 1373 p., 1956.

A comprehensive collection of information and references is presented.

Shocklex, Dale R.

Capacity of soil to hold moisture: Agr. Eng., v. 36, no. 2, p. 109-112, 1955.

Evidence exists that 25 to 50 percent of available soil moisture is not readily available for crop growth. The total readily available moisture is found to vary with total available moisture and with the depth zone.

Shockley, Deli G. See Criddle, W. D., 2; Haise, H. R., 2.

Shockley, W. G. See Kolb, C. R.

SHOEMAKer, R. R.

(and Thorley, T. J.). Problems of ground subsidence: Am. Water Works Assoc. Jour., v. 47, no. 4, p. 412-418, 1955.

Causes, effects, and remedies are described.

Shor, Arthur. See Vaughn, J. C.

Shukry, Aly S. See Fathy, A.

Shulits, SAM. See also Carlson, E. J.; Laursen, E. M., 2.

Graphical analysis of trend profile of a shortened section of river: Am. Geophys. Union Trans., v. 36, p. 649-654, 1955.

The effect on the profile of shortening a reach of river by cutoffs is analyzed graphically.

Sibley, Alden K.

1. Flood control in New England: Am. Soc. Civil Engineers Proc., v. 84, no. WW 1, Paper 1517, 31 p., 1958.

Methods employed for protection against both river and tidal flooding are described.

2. Passamaquoddy-Power from the tides?: Civil Eng., v. 28, p. 66-69, Dec. 1958.

The investigations of the Corps of Engineers are described. 
SibuL, O. J.

(and Johnson, J. W.). Laboratory study of wind tides in shallow water: Am. Soc. Civil Engineers Proc., v. 83, no. WW 1, Paper 1210, 32 p., 1957.

Wind tides and wave conditions were studied in a laboratory channel under variable conditions of wind velocity and bottom roughness.

Silberman, Edward. See Straub, L. G., 1.

Simaika, Y. M. See Fathy, A.

Simmons, Henry B. See also Schultz, E. A., 2.

Some effects of upland discharge on estuarine hydraulics: Am. Soc. Civil Engineers Proc., v. 81, Paper 792, 20 p., 1955.

This paper describes the broad relationships between the volume of discharge into estuaries and their hydraulic and shoaling regimens.

Srmons, D. B. See Liu, H. K., 1.

Srmons, W. D. See Meier, M. F.; Nelson, M. W.

Simpson, E. S.

(and Beetem, W. A., and Ruggles, F. H.). Radiotracer experiments in the Mohawk River, New York, to study sewage path and dilution: Am. Geophys. Union Trans., v. 39, p. 427-433, 1958.

Sewage dosed with a radiotracer was discharged into the river, and its pattern of diffusion was measured. The path of the sewage was influenced by density differences and temperature.

Simpson, R. H. See Gentry, R. C., 2.

Sinclair, J. D. See also Hopkins, W., 3.

(and Hamilton, E. L.). Streamflow reactions of a fire-damaged watershed: Am. Soc. Civil Engineers Proc., v. 81, Separate 629, 17 p., 1955.

Analyses of rainfall and streamflow records in Southern California show that peak flows and storm discharges from a damaged watershed were greatly increased by the effects of the fire.

Singer, Irving A.

(and Brown, Robert M.). The annual variations of sub-soil temperature about a 600-foot circle: Am. Geophys. Union Trans., v. 37, p. 743-748, 1956.

Analysis of 1 year of data showed that differences in ground cover have an appreciable effect on the temperature at all measuring depths.

Singewald, Joseph T., Jr. See Love, C. L.

Sinnott, Allen.

(and Tibbitts, G. Chase, Jr.). Records of selected wells on the eastern shore peninsula, Virginia: Va. Div. Geology Mineral Resources Circ., no. 3, 39 p., 1955.

Well logs and chemical analyses of ground water are included.

Siple, George E.

Ground water in the South Carolina coastal plain: Am. Water Works Assoc. Jour., v. 49, no. 3, p. 283-300, 1957.

This paper discusses the geology, ground-water hydrology, fluctuations of well levels, and the chemistry of the water. (Corrections, v. 49, no. 4, p. 456, 1957; v. 49 , no. 6, p. 742,1957 .) 
Sisson, W. H.

Recharge operations at Kalamazoo: Am. Water Works Assoc. Jour., v. 47, no. 9, p. 914-922, 1955.

A successful recharge operation using ponds is described.

Stvadjian, Joseph.

Hygrophotographic method for depicting soil moisture: Soil Sci., v. 83, no. 2, p. 109-112, 1957.

Use of a special photographic plate which is sensitive to moisture is described.

Skibitzke, H. E. See Wolcott, H. N.

Skinner, Thomas C.

Climatic influences on crop water requirements: Am. Soc. Civil Engineers Proc., v. 83, no. IR 2, Paper 1379, 11 p., 1957.

Work done to date in the field of crop water requirements is discussed.

Slaughter, Turbir H. See Overbeck, R. M.; Rasmussen, W. C., 1, 3.

Smiley, Terah L.

Geochronology, with special reference to southwestern United States: Ariz. Univ. Bull., v. 26, no. 2, 200 p., 1955.

The report covers geochemistry and radiochemical dating, stratigraphy, paleontology, pollen analysis, varve studies, the carbon-14 method of dating, dendrochronology, paleoclimatology, and others.

Sмiтh, C. E. See Bloodgood, D. E.

Smith, Charles J. See Whisler, B. A.

Smith, Davio B.

1. (and Richheimer, Charles E.). Cost estimates favor electrodialysis for treatment of saline waters: Civil Eng., v. 26, p. 60-63, Apr. 1956.

Several methods of obtaining fresh water from saline water and the relative cost by each method are given.

2. (and Richheimer, Charles E.). Recovery of usable water from saline water: Fla. Univ. Eng. and Indus. Expt. Sta., 63 p., 1956.

3. (and Richheimer, Charles E.). Recovery of usable water from saline water: Am. Soc. Civil Engineers Trans., v. 122, p. 556-563, 1957.

Methods of recovery of usable water from saline water are given, and the economics of each method developed.

Sмrтн, Dwight D. See also Wischmeier, W. H., 2, 3.

1. Storage pond design: Agr. Eng., v. 36, no. 11, p. 743-746, 1955.

Design factors are consumptive use, evaporation and seepage losses, and watershed yield. Data collected on two small areas in Missouri are given.

2. (and Wischmeier, Walter H.). Factors affecting sheet and rill erosion: Am. Geophys. Union Trans., v. 38, p. 889-896, 1957.

The two principal processes by which sheet erosion occurs and the six factors which affect the magnitude of the losses are given. The relative effectiveness of three conservation practices is presented. The factors and practices are combined in an equation for field soil loss.

Sмrтн, F. A.

Logs of test holes; Antelope, Boone, Knox, and Pierce Counties, Nebraska: Nebr. Univ. Conserv. and Survey Div. Pub. Suppl. 59, 75 p., 1958. 
Smith, F. B.

The effect of organic matter on aggregation, permeability, and runoff: Jour. Soil and Water Conserv., v. 10, no. 2, p. 76-77, 1955.

Organic matter increases permeability and decreases runoff and erosion losses.

Smith, Guy D.

(and Ruhe, Robert V.). How water shaped the face of the land, in U.S. Department of Agriculture, Water: Yearbook of Agriculture 1955, p. 121-126.

Erosion, infiltration, and solution alter the landscape.

Sмiтh, H. A.

The Chestuee watershed project: Soc. Am. Foresters Proc., p. 110-113, 1956.

An experiment in small watershed development by local agencies and the TVA is described.

Sмrтh, H. F. See Rose, H. G.

Sмгтн, H. V.

The climate of Arizona: Ariz. Agr. Expt. Sta. Bull. 279, 101 p., 1956.

A summary of the climatic data of nearly 300 weather observing stations is given.

SMith, JAMES L.

(and Crabb, George A., Jr.). Patterns and classes of rainfall at East Lansing, Michigan, and their effect upon surface runoff: Mich. Agr. Expt. Sta. Quart. Bull., v. 39, no. 1, p. 47-62, 1956.

Some of the relationships found to exist between patterns and classes of rainfall and the occurrence of surface runoff from the watersheds are presented.

Smiti, Ollie, JR. See Newcome, R., Jr., 2.

Smith, R. C. See Stringfield, V. T.

SMrTh, R. E.

Geology and ground-water resources of Torrance County, New Mexico: N. Mex. Bur. Mines and Mineral Resources Ground-Water Rept. 5, 186 p., 1957.

The report describes the area, general principles of geology and ground water, quality of ground water, rock units, geology and ground water by areas, and community supplies.

Smith, Robert L. See Hutchins, W. A., 6; Lunetta, A. M.

Smith, Stephen C. See Ciriacy-Wantrup, S. V.; Krutilla, J.

Smith, Waldo. See Weickmann, H.

Smrita, R. V. See Hutchins, W. A., 6.

SNIDER, RoberT G.

Your share of tomorrow's water: Agronomy Jour., v. 49, no. 4, p. 167-172, 1957.

The present situation, the future, the problems, and possible solutions are discussed.

SNIEgockI, R. T.

Ground-water resources of the Prairie Creek unit of the lower Platte River basin,

Nebraska, with a section on chemical quality of ground water, by F. H. Rainwater:

U.S. Geol. Survey Water-Supply Paper 1327, 133 p., 1955.

Aquifers in this area of cultivated land are described geologically and with respect to physical and hydrologic properties. Ground-water occurrence, movement, quality, and use are given.

Snow, Beveruy C.

Eastern water shortage and drought problems, growth of eastern irrigation demands: 
Am. Water Works Assoc. Jour., v. 47, no. 3, p. 226-229, 1955.

This paper describes the increased demands for water and legal aspects of use in the Carolinas.

SNyder, C. M. See Wiegel, R. L.

SNyder, Franklin F.

1. (and Clark, Robert H.). Regulation of Lake Ontario: Am. Soc. Civil Engineers Proc., v. 84, no. HY 3, Paper 1660, 25 p., 1958.

A section on the hydrology of Lake Ontario is included.

2. Synthetic flood frequency: Am. Soc. Civil Engineers Proc., v. 84, no. HY 5, Paper 1808, 22 p., 1958.

A method is presented for computing the flood discharge probability associated with a given rainfall-duration-frequency pattern on various types of areas. (Discussions by Ven Te Chow, J. L. H. Paulhus, v. 85, no. HY 3, Paper 1989, p. 57-64, 1959; Max A. Kohler, v. 85, no. HY 4, Paper 2012, p. 109-111, 1959; and author's closure, v. 85 , no. HY 10, Paper 2235, p. 133-140, 1959.)

\section{SNyder, J. Herbert.}

Ground water in California, the experience of Antelope Valley: Calif. Univ. Agr. Expt. Sta. Giannini Found. Ground Water Studies, no. 2, 171 p., 1955.

The economic and social problems arising from dependence on ground water were investigated.

Snyder, Willard M. See also Cooper, A. J.; Koelzer, V. A., 1; Langbein, W. B., 1; Rockwood, D. M., 2.

Hydrograph analysis by the method of least squares: Am. Soc. Civil Engineers Proc., v. 81, Paper 793, 25 p., 1955.

Hydrographs of 10 storms were analyzed. By iterative solution, coefficients of distribution of total runoff and estimates of the total runoff volume were obtained simultaneously.

Soil Conservation Society of America.

1. The nation's available water resources: Jour. Soil and Water Conserv., v. 10, no. 3, p. 133-136, 1955.

A general description is given.

2. The nation's water resource problems: Jour. Soil and Water Conserv., v. 10, no. 4, p. 197-200, 1955.

Erosion, flooding, sediment, water shortages, drainage, and irrigation are discussed.

Sowder, Arthur M.

The age-old debate about a forked stick, in U.S. Department of Agriculture, Water:

Yearbook of Agriculture 1955, p. 118-119.

Some of the pro and con arguments are reviewed.

SPANSKI, RoBert F.

Geophysical techniques in the location of new sources of water: Am. Water Works Assoc. Jour., v. 50, no. 2, p. 175-178, 1958.

The seismic and electrical-resistivity methods are described and compared.

Spar, Jerome.

A weather control experiment in the Eastern United States: N.Y. Acad. Sci. Trans., ser. 2, v. 17, no. 8, p. 621-626, 1955.

The report describes a cloud-seeding experiment off the east coast. The effect, if any, was too small to be detected. 
Spector, Albert H. See Albert, F. A.

SPEeR, P. R.

1. (and Goodwin, A. B.). Index of surface-water records to September 30, 1955, part 2, South Atlantic slope and eastern Gulf of Mexico basins: U.S. Geol. Survey Circ. 382, 24 p., 1956.

This index gives drainage area and period of record.

2. Index of surface-water records to September 30,1955, part 3, Ohio River basin: U.S. Geol. Survey Circ. 383, 28 p., 1956.

This index gives drainage area and period of record.

Spencer, Clyde H. See Morris, S. B., 1.

Spencer, J. R. See Pillsbury, A. F.

Spicer, H. Cecil. See Norris, S. E., 4.

Spiegel, S. J. See Hoffman, J. F.

Spiegel, Zane.

Geology and ground-water resources of northeastern Socorro County, New Mexico:

N. Mex. Bur. Mines and Mineral Resources Ground-Water Rept. 4, 99 p., 1955.

The report presents results of an investigation to determine how and where ground water occurs in the area, in what quantities, and of what quality.

Spock, M., JR. See Huff, F. A., 5.

Stackhouse, J. L.

Problems of snow removal in mountain passes for 1955-1956: Western Snow Conf. Proc., p. 13-15, Apr. 1956.

The report contains data on accumulated snowfall and on snow depths in the Cascade Mountains.

Stafford, H. M. See Rantz, S. E.

Stage, A. R.

Some runoff characteristics of a small forested watershed in northern Idaho: Northwest Sci., v. 31, p. 14-27, 1957.

It is concluded from 16 years of record that two-thirds of the annual runoff of Benton Creek occurs in the period April through June. Average annual runoff and evapotranspiration losses are estimated for a 45 -year period.

Stall, J. B. See also Chien, N., 1.

(and Rupani, N. L., and Kandaswamy, P. K.). Sediment transport in Money

Creek: Am. Soc. Civil Engineers Proc., v. 84, no. HY 1, Paper 1531, 27 p., 1958.

Money Creek flows into Lake Bloomington. Sediment surveys were made of the lake in 1948, 1952, and 1955. The total quantity of bed material moved by the creek immediately upstream from the lake was calculated using each of three sediment transport relationships.

Stallings, J. H.

Soil Conservation: Englewood Cliffs, N.J., Prentice-Hall, 575 p., 1957.

The major parts are introduction, fundamental considerations of soil conservation, conservation practices, and farm and watershed planning.

Stallman, Robert W.

Numerical analysis of regional water levels to define aquifer hydrology: Am. Geophys. Union Trans., v. 37, p. 451-460, 1956. 
Water-level altitudes are analyzed using finite difference approximations of the basic differential equation which describe ground-water flow.

\section{Stanford Research Institute.}

Economic consideration in the formulation and repayment of California water plan projects: Los Angeles, Calif., Haynes Foundation, 124 p., 1958.

This is a research report intended to be of use to the State.

\section{Stanley, Lewis A.}

State versus federal control of Western waters: Am. Soc. Civil Engineers Proc., v. 84, no. IR 3, Paper 1753, 7 p., 1958.

The Supreme Court decision in the Pelton Dan case is examined for its effect on State control of nonnavigable waters.

Staple, W. J.

(and Lehane, J. J.). The influence of field shelterbelts on wind velocity, evaporation, soil moisture and crop yield: Canadian Jour. Agr. Sci., v. 35, no. 5, p. 440-453, 1955.

Shelterbelts probably have no appreciable effect on soil moisture conservation based on 5 years of measurements.

Stark, D. D. See Kuder, W. B.

Starosolszky, O. See Thomas, C. W.

Steece, Fred V.

Geology and shallow ground water resources of the Watertown-Estelline area, South Dakota: S. Dak. Geol. Survey Rept. Inv., no. 85, 36 p., 1958.

Steele, Harry A.

(and Sandals, Kirk M.). A law that puts responsibility at home, in U.S. Department of Agriculture, Water: Yearbook of Agriculture 1955, p. 165-170.

The Watershed Protection and Flood Prevention Act-events leading to its development and passage, and its provisions.

Steele, J. G. See Blakely, B. D.

Stein, Murray.

Proposed changes in eastern water use policies: Am. Soc. Civil Engineers Proc., v. 84, no. SA 5, Paper 1777, 6 p., 1958.

Changing uses of water in the Eastern States are compared with uses of water in the Western States. Work needed on a "Model Water Use Act" is considered. (Discussions by Thomas R. Camp, v. 84, no. SA 6, Paper 1855, p. 25-27, 1958; Samuel A. Greeley, v. 85, no. SA 1, Paper 1921, p. 33-34, 1959; Howard M. Turner, v. 85, no. SA 2, Paper 1985, p. 113-114, 1959; Thomas M. Stetson, v. 85, no. SA 3, Paper 2044, p. 83-85, 1959.)

Stephens, John C.

Subsidence of organic soils in the Florida Everglades: Soil Sci. Soc. America Proc., v. 20 , no. 1, p. $77-80,1956$.

Subsidence is related to depth to water table and averages about $1 \frac{1}{4}$ inches per year.

\section{Stephens, UeL.}

Research and experiments in evaporation reduction: Am. Water Works Assoc. Jour., v. 50, no. 7, p. 816-854, 1958.

Results indicate that ways will be developed shortly for reducing evaporation from small ponds as much as 40 percent by applying a monomolecular film. 
Sterling, Clarence I., Jr.

A water-resource program for Massachusetts: New England Water Works Assoc. Jour., v. 71, no. 4, p. 313-327, 1957.

Water-resource problems and the establishment and operation of a Water Resources Commis sion are described.

Stetson, 'Thomas M. See Stein, M.

Stevens, Henry W.

Data on ice thickness: Eastern Snow Conf. Proc., v. 3, p. 8-19, 1955.

Available data for North America are summarized.

Stevens, J. C. See also Bethlahmy, N., 3.

Flow th:ough circular weirs: Am. Soc. Civil Engineers Proc., v. 83, no. HY 6, Paper 1455, 24 p., 1957.

A form la for theoretical flow through sharp-crested circular weirs is presented. (Discussions by Madhav Manohar, Fred W. Blaisdell, W. T. Moody, M. Jean Rigard, M. B. McPherson, Steponas Kolupaila, v. 84, no. HY 3, Paper 1690, p. 33-53, 1958; and author's closure, v. 85, no. HY 1, Paper 1919, p. 85-98, 1959.)

Stewart, Gordon L.

(and Taylor, Sterling A.). Field experience with the neutron-scattering method of measuring soil moisture: Soil Sci., v. 83, no. 2, p. 151-158, 1957.

Two yecrs of field experience in the development of instruments and techniques is reported.

Stinson, :I. R. See Kuder, W. B.

Stoeckerin, Joseph H. See also Thames, J. L., 1.

(and Thames, J. L.). The Lake States penetrometer for measuring depth of soil freezing: Soil Sci., v. 85, no. 1, p. 47-50, 1958.

This paper reports on the design and use of a steel probe penetrometer useful for rapid reıonnaissance of depth of concrete type of frost where depth of soil freezing is comperatively shallow.

Stoker, J. J. See Isaacson, E.

Stoltenb.r., N. L. See Veihmeyer, F. J., 1.

Stouzy, L. H. See also Weeks, L. V.

(and Ca coon, G. A.). A field-calibrated portable neutron rate meter for measuring soil moisture in citrus orchards: Soil Sci. Soc. America Proc., v. 21, no. 6, p. $571-575,1957$.

The eqt ipment used and the method of calibration have given very satisfactory results.

STONe, A W.

High da ns and upstream storage: Missoula, Mont. State Univ. Press, 175 p., 1958.

The rep ort gives the proceedings of the second annual water resources conference which was dedicated to public education on the merits and demerits of upstream water and reservoir proposals, particularly with regard to the upstream state. Fourtee: 2 papers are included.

Stone, Aj.BERT. See Groff, S. L.

Stone, J. F.

(and Ki:kham, D., and Read, A. A.). Soil moisture determination by a portable neutron scattering moisture meter: Soil Sci. Soc. America Proc., v. 19, no. 4, p. 41!-423, 1955. 
The device and its use are described, and field data are presented. Only one calibration curve is required, and reliable results have been obtained.

Stone, Ralph. See Krone, R. B.; Orlob, G. T., 2.

Storey, Herbert C. See also Lull, H. W., 4; Pierce, R. S., 2.

Frozen soil and spring and winter floods, in U.S. Department of Agriculture, Water:

Yearbook of Agriculture 1955, p. 179-184.

The effects of each of four characteristics of frozen soil on floods are described.

Stout, G. E. See also Huff, F. A., 2; Schuetz, J.

(and Hiser, H. W.). Radar scope interpretations of wind, hail, and heavy rain storms between May 27 and June 8, 1954: Am. Meteorol. Soc. Bull., v. 36, no. 10, p. 519-527, 1955.

Detailed field data and radar observations were studied for a period in which five out of eight storms produced considerable damage. Radar appears useful in shortrange forecasting, but limitations are noted.

\section{Strahler, Arthur N.}

1. Quantitative slope analysis: Geol. Soc. America Bull., v. 67, p. 571-596, 1956. A method is developed to determine slope mean and variance and general form of slope distribution within small limits. This allows objective tests of differences between regions.

2. Quantitative analysis of watershed geomorphology: Am. Geophys. Union Trans., v. 38, p. 913-920, 1957.

Quantitative geomorphic methods provide means of measuring size and form properties of drainage basins. Two general classes of descriptive numbers and examples of each are given.

3. Dimensional analysis applied to fluvially eroded landforms: Geol. Soc. America Bull., v. 69, p. 279-300, 1958.

Dimensional analysis provides a systematic means of describing and comparing the form elements of the landscape. Many such dimensions are given.

Straka, G. C.

(and Schneider, Robert). Graphs of ground-water levels in Minnesota through 1956: Minn. Div. Water Bull. 9, 42 p., 1957.

Stramel, G. J.

1. Progress report on the ground-water hydrology of the Equus Beds area, Kansas: Kans. Geol. Survey Bull. 119, pt. 1, 59 p., 1956.

This report describes an investigation of the general hydrology and the availability of ground water in the well field of the city of Wichita.

2. The hydraulic properties of the Ordovician rocks at Pittsburg, Kansas: Kans.

Geol. Survey Bull. 127, pt. 5, p. 153-178, 1957.

Average values of the coefficients of transmissibility and storage computed from aquifer tests were 250,000 gallons per day per foot and $4.6 \times 10^{-4}$, respectively. The general regional decline of water level is discussed.

3. (and Lane, Charles W., and Hodson, Warren G.). Geology and ground-water hydrology of the Ingalls area, Kansas: Kans. Geol. Survey Bull. 132 [Univ. Kans. Pub.], 154 p., 1958.

Straub, Conrad P. See also Hahn, R. B.; Setter, L. R., 3.

(and Ludzack, F. J., Hagee, G. R., and Goldin, A. S.). Time of flow studies, Ottawa River, Lima, Ohio: Am. Geophys. Union Trans., v. 39, p. 420-426, 1958. Chemical, colorimetric, and radioactive tracer techniques were used to measure the 
time of flow of the river. All tracers gave similar results. The equipment, facilities, tests, costs, and limitations are described.

Straub, Lorenz G.

1. (and Silberman, Edward, and Nelson, Herbert C.). Some observations on open channel flow at small Reynolds numbers: Am. Soc. Civil Engineers Proc., v. 82, no. EM 3, Paper 1031, 28 p., 1956.

This paper contains summaries and correlations of results of studies of open-channel flow for Reynolds numbers less than $4 \times 10^{4}$. (Discussions by Wallace M. Lansford, James M. Robertson, C. J. Posey, v. 83, no. EM 1, Paper 1154, p. 5-13, 1957; corrections and authors' closure, v. 83, no. EM 3, Paper 1311, p. 5-6, 1957.)

2. (and Lamb, Owen P.). Studies of air entrainment in open-channel flows: Am.

Soc. Civil Engineers Trans., v. 121, p. 30-44, 1956.

This paper describes the results of experimental observations of self-aerated flows in an open channel for various slopes.

3. (and Anderson, Alvin G.). Experiments on self-aerated flow in open channels: Am. Soc. Civil Engineers Proc., v. 84, no. HY 7, Paper 1890, 35 p., 1958.

Air content of water in high-velocity flow can be related to flow characteristics and described by turbulence concepts. (Discussion by Michele Viparelli, v. 85, no. HY 6, Paper 2076, p. 75-78, 1959; and authors' closure, v. 85, no. HY 11, Paper 2269, p. 119-121, 1959.)

Strauss, Fred A. See Burns, J. I.

Streicher, LeE. See also Hartung, H. O.

Effects of water quality on various metals: Am. Water Works Assoc. Jour., v. 48, no. 3, p. 219-238, 1956.

The report describes corrosion studies in six waters furnished by Metropolitan Water District of Southern California.

STRINGFIELD, V. T.

(and Smith, R. C.). Relation of geology to drainage, floods, and landslides in the Petersburg area, West Virginia: W. Va. Geol. and Econ. Survey Rept. Inv., no. 13,19 p., 1956.

The report describes the record-breaking flood of June 17-18, 1949, and relates its effects to geology.

STULL, KEEFER S.

Ultrasonic phase meter measures water velocity: Electronics, v. 28, no. 9, p. 128$131,1955$.

Magnitude and direction of subsurface water currents at remote locations are automatically measured and recorded by instrument incorporating phase measurement circuit.

Subitzky, Seymour.

Summary of geology and ground-water conditions in the Fredericksburg district, eastern Spotsylvania County, Virginia-a preliminary report: Va. Div. Geology Mineral Resources Circ., no. 4, 32 p., 1955.

Sundstrom, R. W.

Ground water resources in Texas: Am. Water Works Assoc. Jour., v. 47, no. 7, p. 695-702, 1955.

The resources and present use are described.

Suom, V. E. See also King, K. M.

(and Tanner, C. B.). Evapotranspiration estimates from heat-budget measure- 
ments over a field crop: Am. Geophys. Union Trans., v. 39, p. 298-304, 1958. The evapotranspiration from a crop can be estimated from the disposition of solar and sensible energy a vailable at the earth-air interface. A suitable measurement of the heat budget will account for the fraction of solar energy used for evapotranspiration. The theory, the experimental equipment, and some illustrative measurements are discussed.

Sutcliffe, Horace, Jr. See also LaMoreaux, P. E., 1.

(and Newton, J. G.). Interim report on the geology and ground-water resources of Marengo County, Alabama: Ala. Geol. Survey Inf. Ser. 1, 64 p., 1957.

Suter, Max.

1. The Peoria recharge pit; Its development and results: Am. Soc. Civil Engineers Proc., v. 82, no. IR 3, Paper 1102, 17 p., 1956.

Research on artificial recharge by the Illinois State Water Survey led to a method for maintaining a high rate of inflow to the aquifer.

2. High-rate recharge of ground water by infiltration: Am. Water Works Assoc. Jour., v. 48, no. 4, p. 355-360, 1956.

A recharge pit with the high rate of $20-25$ million gallons per day per acre was achieved.

Sutton, John G.

Appraising our drainage job: Land Improvement, p. 7-10, Apr. 1958.

Drainage is one of the essential water management practices in comprehensive watershed and soil conservation programs.

SvobodA, R. F. See Reed, E. C.

Swanson, R. W. See van Bavel, C. H. M., 3.

Swantue, H.

Photogrammetric methods in reforestation surveys: Photogramm. Eng., v. 23, no. 3, p. 789-790, 1957.

Photogrammetric methods are cheaper and give more information than field-sampling methods.

Swartz, B. W.

1. Records of water levels in Bastrop and Caldwell Counties, Texas, 1937 through Dec. 1956: Texas Board Water Engineers Bull. 5702, 22 p., 1957.

2. Records of water levels in Aransas and San Patricio Counties, Texas, 1938 through Dec. 1956: Texas Board Water Engineers Bull. 5703, 24 p., 1957.

Swartzendruber, Dale.

1. (and Kirkham, Don). Capillary fringe and the flow of water in soil: Soil Sci., v. 81 , no. 6 , p. $473-484,1956$.

Two different theoretical cases which elucidate observed capillary flow phenomena are discussed. A capillary fringe may either increase or decrease the flow which would occur without the fringe. The conditions which determine whether an increase or a decrease will occur are described.

2. (and Kirkham, Don). Capillary fringe and flow of water in soil; II. Experimental results: Soil Sci., v. 82, no. 1, p. 81-95, 1956.

In a previous paper the authors solved a two-dimensional capillary flow problem. In this paper an experimental flow model is tested and the results are found to agree well with the theory. It is demonstrated that a substantial contribution to flow from the capillary region can exist. The experiments also revealed that the shape of the water table depends on the size of the capillary region. 
3. (and Huberty, M. R.). Use of infiltration equation parameters to evaluate infiltration differences in the field: Am. Geophys. Union Trans., v. 39, p. 84-93, 1958.

Constants in an infiltration equation are tested for their usefulness in characterizing infiltration in field basins. A product parameter is recommended.

SwaYne, W. W.

Quantitative analysis and forecasting of winter rainfall patterns: Monthly Weather Rev., v. 84, no. 2, p. 53-65, 1956.

The analysis procedure describes the horizontal transport of saturated air through a stationary temperature field. The forecast procedure is based on short period extrapolations of the moisture, motion, and temperature fields and the volumetric flow of moisture across the Gulf Coast. The rainfall center is located by the position of maximum moisture advection. Results of a systematic test of the forecasts are included.

SweET, JAMES S.

1. American-Russian, Russian-American hydrologic vocabulary: U.S. Weather Bur., 1958.

A vocabulary of about 300 words most frequently used in the American and Russian hydrologic literature is given.

2. American-Spanish, Spanish-American hydrologic vocabulary: U.S. Weather Bur., 1958.

A vocabulary of about 330 terms most frequently used in the United States and the Spanish language hydrologic literature is given.

SWENGeL, R. C.

(and Hess, W. B., and Waldorf, S. K.). Principles and application of the ultrasonic flowmeter: Am. Inst. Elec. Engineers Trans., v. 74, no. 17, pt. 3, p. 112-118, 1955.

In hydroelectric turbine testing, a single ultrasonic flow measurement and calculation is made in about 15 minutes.

Swensen, Edmond I. See Thames, J. L., 2.

Swenson, Frank A.

1. Geology and ground-water resources of the Missouri River valley in northeastern Montana, with a section on the quality of the ground water, by Walton $\mathrm{H}$. Durum: U.S. Geol. Survey Water-Supply Paper 1263, 128 p., 1955.

The various aquifers are located and described, and the yield and quality of the ground water from each aquifer are generalized from well records.

2. Geology and ground water, Heart Mountain and Chapman Bench Divisions, Shoshone irrigation project, Wyoming, with a section on chemical quality of the water, by Herbert A. Swenson: U.S. Geol. Survey Water-Supply Paper 1418, 55 p., 1957.

After irrigation has been practiced for some time, a shallow body of ground water will probably form.

3. Geology and ground-water resources of the Lower Marias irrigation project, Montana, with a section on chemical quality of the ground water, by Herbert A.

Swenson: U.S. Geol. Survey Water-Supply Paper 1460-B, p. 41-98, 1957.

The occurrence and chemical quality of the ground water are related to the geology of the area.

Swenson, Herbert A. See also Bjorklund, L. J., 2; Dingman, R. J., 1; Griffin, W. C.; Lorenz, H. W.; Swenson, F. A., 2, 3; Torrey, A. E. 
(and Colby, B. R.). Chemical quality of surface water in Devils Lake basin, North Dakota: U.S. Geol. Survey Water-Supply Paper 1295, 82 p., 1955.

Hydrologic changes that may have caused Devils Lake to alter from a large, moderately deep lake of fresh water to a small, shallow body of brackish water are discussed and evaluated. Chemical and physical characteristics of the Lake water are given, and probable concentrations are computed for the condition that the lakes are filled by diversions from outside the basin.

Sylvester, Robert O.

Water-quality studies in the Columbia River Basin: U.S. Fish and Wildlife Service Spec. Sci. Rept., Fisheries no. 239, 134 p., 1958.

Water-quality constituents evaluated were those that might relate to the productivity of the River Basin fishery. Water quality has experienced a significant change in the past 45 years through construction of dams.

Symons, George E.

1. Properties of water-I: Water and Sewage Works, v. 103, no. 12, p. 537-541, 1956.

The report describes the fundamental physical properties of water.

2. Properties of water-II: Water and Sewage Works, v. 104, no. 3, p. 105-108, 1957.

The report describes the chemical properties of water.

Szalay, N. See Robinson, A. R., Jr., 2.

TanNehill, Ivan R.

1. Is weather subject to cycles?, in U.S. Department of Agriculture, Water: Yearbook of Agriculture 1955, p. 84-90.

No clear-cut cycle has been found.

2. Hurricanes, their nature and history: Princeton, N. J., Princeton Univ. Press, 308 p., 1956.

A historical account is given of hurricanes, their tracks, characteristics, and the damage resulting (to 1955).

3. The hurricane: Washington, U.S. Govt. Printing Office, 22 p., revised 1956.

Paper defines a hurricane and gives information concerning history of hurricanes, cause and formation, regions of formation, motions of storms, irregular movements, wind system of hurricanes, the "eye of the storm," barometric pressure, rainfall, storm surges, the law of storms, dimensions of the hurricane, precursory signs, frequency, and hurricane warnings.

TANner, C. B. See also Bourget, S. J.; King, K. M.; Suomi, V. E.

Factors affecting evaporation from plants and soils: Jour. Soil and Water Conserv., v. 12 , no. 5 , p. 221-227, 1957.

The three factors which affect evapotranspiration from crops are climate, soil moisture availability, and the physiological reaction of the plant to the difference between moisture availability and the evaporation demand.

TanNer, Wiluiam F.

Parallel slope retreat in humid climate: Am. Geophys. Union Trans., v. 37, p. 605-607, 1956.

One hundred forty-five slope measurements in Northern Alabama were studied.

Tarble, Richard D. See Allen, F. C.; Bigler, S. G.

Tarrant, Robert F.

Soil moisture conditions after chemically killing manzanita brush in central Oregon: 
U.S. Forest Service, Pacific Northwest Forest and Range Expt. Sta. Research Note 156, 4 p., 1957.

Killing manzanita brush with chemical greatly reduced soil moisture loss during the summer drought. The amount of moisture saved was about the same, whether dead brush was removed or left standing.

Tarver, George R.

Interim report on the ground-water resources of St. Johns County, Florida: Fla. Geol. Survey Inf. Circ., no. 14, 36 p., 1958.

Artesian pressure head fluctuates through a range of 5 feet per year. Chloride content increases with depth.

Tarzwell, C. M. See Gaufin, A. R., 1.

TAtor, B. A.

The aerial photograph and applied geomorphology: Photogramm. Eng., v. 24, no. 4 , p. 549-561, 1958.

Application of geomorphological principles by the trained field geologist utilizing stereoscopic aerial photography is producing fruitful results in the analysis of low-relief terrains.

TAYLOR, E. H.

(and Huberty, M. R.). Water resources research in the University of California:

Calif. Univ. Water Resources Center Contr., no. 10, 78 p., 1957.

The report gives the proceedings of a conference and contains five papers each on water supply and on distribution and uses.

TAYLOR, RoBert E.

Some properties of 144 soils from three Intermountain States: U.S. Forest Service, Intermountain Forest and Range Expt. Sta. Misc. Pub. 7, 15 p., 1956.

The report presents data on mechanical composition, organic matter, stone content, $\mathrm{pH}$, and plasticity constants.

Taylor, Sterling A. See also Stewart, G. L.; Veihmeyer, F. J., 1.

1. Field determinations of soil moisture: Agr. Eng., v. 36, no. 10, p. 654-659, 1955. Several methods of measuring moisture are compared. None of the presently available field methods are completely satisfactory.

2. (and Haddock, J. L.). Soil moisture availability related to power required to remove water: Soil Sci. Soc. America Proc., v. 20, no. 2, p. 284-288, 1956.

Some theoretical predictions are made and partially verified by experiment.

Tedrow, J. C. F. See Drew, J. V.

Tenny, Alfred. See Vaughn, J. C.

Terreli, D. V. See Penrod, E. B.

Terrell, Pete W.

(and Borland, Whitney M.). Design of stable channels and channels in erodible material: Am. Soc. Civil Engineers Trans., v. 123, p. 101-115, 1958.

Factors that must be considered in the design of a canal are listed and examined. Methods by which the propər size and shape of a channel can be computed are presented, and practical considerations and field experience in channel-stability problems are given.

Tesner, Irving $\mathrm{H}$.

Sample study and correlation of three wells in Chautauqua County, New York; 
a report from the New York State Geological Survey: N.Y. State Mus. and Sci. Service Bull., no. 362, 20 p., 1957.

\section{Texas Board of Water Engineers.}

1. Water rights: Soil and Water, v. 5, no. 7, p. 22-24, 1956.

This is an information release.

2. Surface water reservoirs of Texas, Dec. 1956: Texas Board Water Engineers, 1957.

Reservoirs having capacities of 200 acre feet or more are included. For each reservoir the name, stream, location, storage capacity in acre-feet, and use are given. 3. Texas floods, April-May-June, 1957: Texas Board Water Engineers, 1957. The floods were outstanding both because of the large geographical area which experienced flood conditions and because of the large volume of runoff produced. This report includes general descriptions of the floods and rainfall information. Streamflow and reservoir contents records at 97 sites throughout the State are also included.

4. Estimated use of groundwater in watersheds of Texas: Texas Board Water Engineers, 12 p., 1957.

Annual use for rural, irrigation, industrial, and municipal purposes for 13 major basins is given.

5. Compilation of surface water records in Texas through September 1957: Texas Board Water Engineers Bull. 5807-A, 503 p., 1958.

Monthly and yearly mean discharge in cubic feet per second, runoff in acre-feet are given, and yearly extremes are given for regular streamflow stations in Texas.

6. Texas index of surface water records-discharge, sediment, chemical quality, and water temperature: Texas Board Water Engineers Bull. 5807-B, 59 p., 1958.

Records are shown graphically.

7. Water developments and potentialities of the State of Texas: U.S. 85th Cong., 2d sess., Senate Doc. 111, 175 p., 1958.

A joint report of the Board of Water Engineers, U.S. Corps of Engineers, Soil Conservation Service, and Bureau of Reclamation which reviews the general overall Texas water situation, the scope of intrabasin water-resource planning and development to date, the opportunity for interbasin water-resource projects, and the responsibilities and capabilities of the agencies involved.

Texas Society of Professional Engineers.

Water: Texas Soc. Prof. Engineers, 67 p., 1955.

A plain statement of some of the problems involved in the development of Texas water resources, with some recommendations for their solution.

Texas University School of Law.

Proceedings, Water Law Conference, May 25-26, 1956: Texas Univ. School Law, 192 p., 1956.

The report contains several papers on each of the following: Financing water development, special procedures for adjudication of water rights and supervision of diversion, selected Texas problems of current importance, and ground-water rights and control.

Thames, John L. See also Stoeckeler, J. H.; Ursic, S. J.

1. (and Stoeckeler, Joseph H., and Tobiaski, Robert). Soil moisture regime in some forest and non-forest sites in northern Wisconsin: Soil Sci. Soc. America Proc., v. 19, no. 3, p. 381-384, 1955. 
In a paired set of sites, there was less available soil moisture in the surface 1 to 2 feet of the forested site than of the site in a hay crop. In two forested sites the amount of water in the surface fost was greater in the site with the higher water table.

2. (and Swensen, Edmond I.). Properties of 160 soils of four north central States: U.S. Forest Servi ze, Lake States Forest Expt. Sta. Paper 38, 15 p., 1956.

The report characterizes the individual sample sites and summarizes theinformation on properties of soils at 160 sites in Iowa, Minnesota, Wisconsin, and Illinois.

3. Hydraulic inserter for soil-moisture units: Soil Sci., v. 86, no. 3, p. 156-159, 1958.

The construction and operation are described.

Thingrisi, Adul. See LaMoreaux, P. E., 2.

Thayer, Donald P. See Jansen, R. B.

Theis, Charles V. See Bean, R. T.

Thiel, E.

(and LaChapelle, E., and Behrendt, J.). The thickness of Lemon Creek Glazier, Alaska, as determined by gravity measurements: Am. Geophys. Union Trans., v. 38, p. 745-749, 1957.

Results of a geophysical exploration are presented on cross-section diagrams and an isopach map.

Tном, H. C. S.

1. Climatological analysis of snowfall thresholds: Eastern Snow Conf. Proc., v. 3, p. 20-29, 1955.

The threshold is the first day in the fall on which $d$-inches or more of snowfall occurs. Thresholds are approximately normally distributed. If the threshold does not occur every year a mixed distribution is used.

2. (and Shaw, R. H.). Climatological analysis of freeze data for Iowa: Monthly Weather Rev., v. 86, no. 7, p. 251-257, 1958.

A set of freeze thresholds is defined to replace the loosely defined element killing frost. A simple form of freeze-free period distribution is found and presented.

Thomas, Charles W.

Common errors in measurement of irrigation water: Am. Soc. Civil Engineers Proc., v. 83, no. IR 2, Paper 1362, 24 p., 1957.

Errors are discussed which result from use of measurement devices having nonstandard dimensions, settings, flow patterns, and other factors. (Discussion by O. Starosolszky, Steponas Kolupaila, Armando Balloffet, v. 84, no. IR 2, Paper 1615, p. 23-30, 1958, and author's closure, v. 84, no. IR 3, Paper 1784, p. 7-10, 1958.)

Thomas, Harold E. See also Critchlow, H. T.; Flaxman, E. M.; Thomas, R. O., 1; Waite, H. A.

1. Underground sources of our water, in U.S. Department of Agriculture, Water: Yearbook of Agriculture 1955, p. 62-78.

The sources, occurrence, and movement of ground water are described.

2. Factors influencing the establishment of a national water policy: Jour. Soil and Water Conserv., v. 12, no. 6, p. 265-268, 1957.

Previous development stressed individual solutions. Emphasis now is on cooperation, collaboration, and coordination.

3. (and White, D. E.). Can we identify non-hydrologic water?: Eng. News-Rec., v. 160, no. 24, p. 55, June 12, 1958. 
The origin of juvenile water and the problems of identification are discussed.

Thomas, Mendall P. See Bigwood, B. L., 1, 2.

Thomas, Nathan O.

(and Harbeck, G. Earl, Jr.). Reservoirs in the United States: U.S. Geol. Survey Water-Supply Paper 1360-A, p. 1-99, 1956.

Descriptive data are given for reservoirs having a capacity of 5,000 acre-feet or more and for natural lakes having a usable capacity of 5,000 acre-feet or more. Included are reservoirs and lakes completed as of Jan. 1, 1954, and reservoirs under construction on that date.

Thomas, R. G. See Isherwood, J. D.

Thomas, Robert O. See also Criddle, W. D., 3 ; Harbeck, G. E., Jr., 2; Willets, D. B.

1. Planned utilization (in Ground water development, a symposium): Am. Soc. Civil Engineers Trans., v. 122, p. 422-433, 1957.

The legal status of ground waters in California is reviewed and recommendations to obtain full beneficial control and use of water supplies are made. (Discussion by Harold E. Thomas and Frank B. Clendenen.)

2. Water-a limiting resource?: Am. Soc. Civil Engineers Proc., v. 84, no. IR 3, Paper 1754, 13 p., 1958.

Availability of water is compared with anticipated demands. (Discussions by Douglas R. Woodward, Alfred R. Golze, Donald McCord Baker, v. 85, no. IR 1, Paper 1986, p. 77-85, 1959; and author's closure, v. 85, no. IR 2, Paper 2073, p. 31-34, 1959.)

Thompson, C. B.

Importance of phreatophytes in water supply: Am. Soc. Civil Engineers Proc., v. 84, no. IR 1, Paper 1502, 17 p., 1958.

The occurrence and spread of salt cedar in New Mexico, its water use, and methods of eradication and control are described.

Thompson, Morris M.

Photogrammetric mapping of sand beds in a hydraulic test flume: Photogramm.

Eng., v. 24, no. 3, p. 468-475, 1958.

The results obtained indicate that the mapping system described can produce 0.01foot contour maps that meet high standards of accuracy.

Thомs, H. W. See Kazmann, R. G., 2.

Thomson, M. T.

1. (and Carter, R. F.). Surface water resources of Georgia during the drought of 1954, part 1, streamflow: Ga. Dept. Mines, Mining, and Geology Inf. Circ., no. 17,79 p., 1955.

This circular describes the effects of the drought, compares the 1954 drought with others, and includes hydrographs for June through November for gaging stations. Measurements of low flow at many partial-record sites are given.

2. (and Herrick, S. M., and Brown, Eugene). The availability and use of water in Georgia: Ga. Dept. Mines, Mining, and Geology Bull., no. 65, 329 p., 1956.

This report summarizes the existing information on the water resources of Georgia and appraises the availability, chemical quality, and present and future utilization. The report is intended to assist in determining whether additional water-resource legislation is needed.

3. Water in Georgia; resources, utilization, legislation; General aspects: Ga. Acad. Sci. Bull., v. 15, no. 3, p. 71-79, 1957. 
A nontechnical discussion is presented.

Thordey, T. J. See Shoemaker, R. R.

Thorne, M. D.

(and Raney, W. A.). Soil moisture evaluation: U.S. Dept. Agriculture, ARS 41-6, 10 p., May 1956.

Methods for the evaluation of soil moisture are reviewed, and the advantages and disadvantages are given.

Thornthwaite, C. W.

1. (and Mather, J. R.). The water budget and its use in irrigation, in U.S. Department of Agriculture, Water: Yearbook of Agriculture 1955, p. 346-358.

The measurement and computation of evaporation and transpiration are described. The difference between requirements and supply is that amount needed for irrigation.

2. (and Mather, J. R.). The water balance: Lab. Climatology, Pubs. Climatology, v. 8, no. 1, 1955.

A review of the authors' and their colleagues' work in the past decade on evapotranspiration-and its complexities and its applications. An extensive bibliography of articles from all parts of the world on evapotranspiration is included.

3. (and Mather, John R.). Instructions and tables for computing potential evapotranspiration and the water balance: Lab. Climatology, Pubs. Climatology, v. 10, no. 3, 1957.

4. (and Mather, John R. and Carter, Douglas B.). 3 water balance maps of eastern North America: Washington, Resources For The Future, Inc., 47 p., 3 maps, 1958.

The text discusses the measurement of evapotranspiration and means of computing the water balance. Maps show potential evapotranspiration, water surplus, and water deficit for North America east of long $87^{\circ} \mathrm{W}$. and south of lat $55^{\circ} \mathrm{N}$.

Thorpe, T. W. See Bergen, S. W.

Thurston, W. R. See Hess, H. H.

Tibbitts, G. Chase, Jr. See Sinnott, A.

Timblin, Lloyd O., JR.

1. (and Moran, Willis T., and Garstka, Walter U.). Use of monomolecular layers for reservoir evaporation reduction: Am. Water Works Assoc. Jour., v. 49, no. 7 , p. 841-848, 1957.

Early fundamental and field studies, the Bureau of Reclamation study, and the need for reliable methods for film detection and for application and maintenance are described.

2. (and Florey, Q. L.). Evaporation loss reduction by monomolecular films, progress report: Four States Irrig. Council, Proc., 7th Ann. Mtg., Denver, Colo., 1958, p. 62-68.

This is a progress report on projects related to use of hexadecanol, such as effect on water quality, techniques of film application and maintenance, and methods of film detection.

Timmons, John F.

(and O'Byrne, John C., and Frevert, Richard K.). Iowa's water resourcessources, uses, and laws: Ames, Iowa State Coll. Press, 225 p., 1956.

Thirty-six papers dealing with many phases of water problems and remedial measures are included. 
Tinney, E. Ror. See Liu, H. K., 1.

Tipron, M. J.

Geology and hydrology of the Parker-Centerville outwash (Turner and Clay

Counties): S. Dak. Geol. Survey Rept. Inv. 82, 19 p., 1957.

The investigation is part of a program to develop the shallow-water resources of South Dakota. Development of the Parker-Centerville outwash can be of great value to the State.

Tison, Gerard, Jr. See Kabelac, O. W.; Petersen, J. S.

Tison, L. J. See Escoffier, F. F., 1; Ingerson, I. M.

Tobiaski, R. A.

(and Larson, D. E.). The development of methods for predicting soil moisture content; Report on the Fairbanks, Alaska, extension: U.S. Army Corps Engineers, Waterways Expt. Sta., Misc. Paper 4-135, 68 p., 1955.

Report describes the Vicksburg Infiltration Project study of the wetting and drying of soils near Fairbanks, Alaska. Relations were developed which allow the prediction of soil-moisture content in similar Arctic soils where only soil and vegetation information and a rain record are available.

Tobiaski, Robert. See Thames, J. L., 1.

Toch, Arthur. See Kindsvater, C. E., 1; Neville, J. F.

Todv, A. R. See Douglass, J. B.

Topd, C. J.

(and MacCready, Paul B., Jr.). Research required to make cloud seeding a quantitative science: Western Snow Conf. Proc., p. 79-83, Apr. 1957.

Solutions to rainfall rate problems are needed.

Todd, David K.

1. Investigating ground water by applied geophysics: Am. Soc. Civil Engineers Proc., v. 81, Separate 625, 14 p., 1955.

Summaries of useful geophysical approaches are presented. Basic principles, methods, applications, and examples, and a selective bibliography are included. 2. Ground-water flow in relation to a flooding stream: Am. Soc. Civil Engineers Proc., v. 81, Separate 628, 20 p., 1955.

This study utilized model measurements to obtain information on the time distribution of ground-water flow during flood periods. Results of the model analogy are interpreted in terms of bank storage volume and distribution, and the magnitude and time distribution of ground-water flow.

3. Flow in porous media studied by Hele-Shaw channel: Civil Eng., v. 25, p. 51, Feb. 1955.

The laboratory channel is described, and its use explained.

4. (and Lau, Leung-Ku). On estimating streamflow into a tidal estuary: Am. Geophys. Union Trans., v. 37, p. 468-473, 1956.

A method of estimating streamflow is described based on continuous salinity recorder data, tidal data, and current tables. The procedure is illustrated by computing streamflows from Sacramento-San Joaquin Valley entering San Francisco Bay. (Discussion by D. W. Pritchard, and authors' closure, v.38, p. 581-584, 1957.) 5. (and Clendenen, Frank B.). Proceedings, Conference on the California Groundwater Situation, Berkeley, California, Dec. 3-4, 1956: Calif. Univ. Comm. Research Water Resources, 212 p., 1956. 
Papers are included on the ground-water resources; progress through research; quality considerations in utilization; and legal, economic, and administrative aspects.

6. (and Ateshian, K. H.). Estimation of flood peaks in the Sierra Nevada Mountains, California: Calif. Univ. Inst. Eng. Research Ser. 102, Issue no. 1, 88 p., 1956.

Ten-year floods were related to drainage area and precipitation intensity.

7. Frequency analysis of streamflow data: Am. Soc. Civil Engineers Proc., v. 83, no. HY 1, Paper 1166, 18 p., 1957.

Frequency analysis is reviewed, and computational procedures are outlined. A list of references is given. (Discussions by H. Alden Foster, v. 83, no. HY 3, Paper 1283, p. 9-10, 1957; M. A. Benson, v. 83, no. HY 4, Paper 1348, p. 21-30, 1957; author's closure, v. 84, no. HY 1, Paper 1558, p. 7, 1958.)

Tolley, George S. See Krutilla, J.

Torrey, Alfred E.

(and Kohout, Francis A.). Geology and ground-water resources of the lower Yellowstone River valley between Glendive and Sidney, Montana, with a section on chemical quality of the water, by Herbert A. Swenson: U.S. Geol. Survey Water-Supply Paper 1355, 92 p., 1956.

This reports an investigation to evaluate the recharge, discharge, storage, and direction of movement of ground water, and to correlate these factors with present and potential irrigation problems.

Tотн, A. S. See Hill, R. A.

Toulmin, L. D. See LaMoreaux, P. E., 1.

Towner, P. A. See Kuder, W. B.

Townsend, George E. See McAleer, J. B.

Tracy, Hubert J.

1. (and Carter, Rolland W.). Backwater effects of open channel constrictions: Am. Soc. Civil Engineers Trans., v. 120, p. 993-1006, 1955.

A method of computing the nominal backwater due to open-channel constrictions was sought. A practicable solution, based on an empirical discharge coefficient and a laboratory investigation of the influence of channel roughness, has been reached. The effects of channel shape and constriction geometry were also investigated in the laboratory. (Discussion by Paul V. Hodges, Carl F. Izzard, and Harold R. Henry.)

2. Discharge characteristics of broad-crested weirs: U.S. Geol. Survey Circ. 397, 15 p., 1957.

Discharge characteristics defined by laboratory tests are described.

Trappe, James M. See Miner, N. H.

Trask, Parker D.

Proceedings, conference on geological engineering problems of water in California, Berkeley, California, March 18-19, 1957: Calif. Univ., Water Resources Center Contr., no. 6, 162 p., 1957.

Papers on various aspects of each of the following general subjects are included: (1) Geological problems of dams, tunnels, and canals, (2) special geological engineering problems, (3) ground water and landslides, and (4) panel discussions of geological engineering problems of water resources.

Trelease, F. J. See Kuder, W. B. 
Trimble, George R., JR. See also Bjorkbom, J. C.; Sartz, R. S., 1; Weitzman, S. 1. Watershed research begins in New Hampshire: Forest Notes, v. 46, p. 22-25, 1955.

The report describes research project at the Hubbard Brook Experimental Forest, West Thornton, N.H.

2. (and Lull, Howard W.). The role of forest humus in watershed management in New England: U.S. Forest Service, Northeastern Forest Expt. Sta. Paper 85, 34 p., 1956.

Characteristics, functions and classifications of forest humus, and research problems are discussed.

3. (and Barraclough, K. E., Breon, Theodore F., and Sargent, Leslie, Jr.). New Hampshire guides for logging roads and skid trails: N.H. Univ. Ext. Folder 35, 4 p., 1957.

Practical guides are given for locating, constructing and maintaining logging roads and skid trails to prevent runoff and erosion.

4. (and Sartz, Richard S., and Pierce, Robert S.). How type of soil frost affects infiltration: Jour. Soil and Water Conserv., v. 13, no. 2, p. 81-82, 1958.

Concrete frost is impermeable, but in the forest it was traversed by large open holes. Granular frost was more permeable than unfrozen soil.

Tripp, Norman R. See also Lull, H. W., 11; Whelan, D. E., 1.

(and Lull, Howard). Management problems and opportunities on forested watersheds in the Northeast: Soc. Am. Foresters Proc., p. 30-32, 1957.

A general discussion is given.

Troesch, A. See Isaacson, E.

Trousdell, Kenneth B.

(and Hoover, Marvin D.). A change in ground-water level after clearcutting of loblolly pine in the Coastal Plain: Jour. Forestry, v. 53, p. 493-498, July 1955.

An experiment in North Carolina showed a considerable rise in ground-water level following clearcutting.

Troxell, Harold C.

Water resources of southern California with special reference to the drought of 1944-51: U.S. Geol. Survey Water-Supply Paper 1366, 139 p., 1957.

This paper discusses hydrologic factors and describes the cultural development of the area with emphasis on water. Water requirements and reserves in eight regions are given.

Tunn, W. L. M. See Von Englehardt, W.

Turcan, A. N., JR. See Meyer, R. R.

Turner, Howard M. See Dalrymple, T.; Stein, M.

Turner, Kenneth M. See Blaney, H. F., 5.

Twichell, Trigg.

Investigations of the hydrology of small watersheds in Texas: Am. Soc. Civil Engineers Proc., v. 82, no. SA 4, Paper 1050, 18 p., 1956.

Basic data are needed to evaluate (1) the natural occurrence, quantity, and quality of water for a region through extended climatic cycles, (2) the interrelationships of surface and ground water, and (3) the effects of man's developments on the water resources. A method of obtaining these data is given.

Trchsen, P. C.

(and Vorhis, R. C.). Reconnaissance of geology and ground water in the lower 
Grand River Valley, South Dakota, with a section on chemical quality of the ground water, by E. R. Jochens: U.S. Geol. Survey Water-Supply Paper 1298, 33 p., 1955.

The area described is the flood plain of Grand River and bordering benchlands. The amount of ground water available from wells and its quality are estimated for each formation.

Uhland, R. E. See Wischmeier, W. H., 2.

ULRICh, A. A.

Chloride contamination of ground water in Ohio: Am. Water Works Assoc. Jour., v. 47 , no. 2, p. 151-152, 1955.

Contamination from highly mineralized wastes may persist for a decade or more in fresh-water aquifers. (Discussion by Art Robinson.)

Underwood, Newton. See van Bavel, C. H. M., 3.

\section{United Nations.}

1. Multiple-purpose river basin development: U.N. Econ. Comm. for Asia and the Far East, Manual River Basin Plan., pt. 1, 79 p., 1955.

The manual deals with the general aspects of planning for multiple-purpose river basin development, with the general reference to Asia and the Far East. Part 2A describes water-resource development in Ceylon, China, Taiwan, Japan, and the Philippines.

2. Integrated river basin development: U.N. Dept. Econ. and Social Affairs Rept., 60 p., 1958.

This report was written specifically for use in water-resource planning in less developed areas of the world.

United Nations Review.

Water and the world today: U.N. Rev., 40 p., July and August 1956.

A brief popular discussion is given.

University of California.

1. Report on recent and current research in water resources: Calif. Univ. Comm. Research Water Resources, Water Resources Center Contr. 12, 90 p., 1957.

The field is surveyed, with special reference to California. Specific studies are identified only by reference.

2. Report on suggestions for research in water resources: Calif. Univ. Water Resources Center Contr. 18, 48 p., 1958.

UNIVERSITY OF KANSAS.

The Kansas basin; pilot study of a watershed: Lawrence, Kans. Univ. Press, 103 p., 1956.

The report describes the Kansas Basin Project.

\section{UNIVERSITY OF MARYLAND.}

Fresh water from the sea; conversion of salt and brackish water: Md. Univ. Bur. Business and Econ. Research, Studies in Business and Economics, v. 12, no. 3, 12 p., 1958.

The report includes technical factors, methods of desaltation, cost factors, and future development.

University of Missouri.

Water: Mo. Univ. Agr. Expt. Sta. Bull. 681, 40 p., 1957.

Talks from the 8th annual Missouri Farm Forum are given. 
UNIVERSITY OF NEBRASKA.

Nebraska Water Conference, February 28-March 1, 1957: Nebr. Univ., 139 p., 1957.

The report is a compilation of papers on water needs, use, resources, law, and problems in Nebraska.

UNIVERSITY OF OKLAHOMA.

Proceedings of the Conference on Water Quality Control for Subsurface Injection held at the University of Oklahoma, Dec. 11, 12, 1956: Okla. Univ., 138 p., 1957.

Upson, Joseph E.

1. Ground water sources on Long Island: Am. Water Works Assoc. Jour., v. 47, no. 4, p. 341-347, 1955.

This paper describes the geologic formations that yield about 260 million gallons per day.

2. (and Kunkel, Fred). Ground water of the Lower Lake-Middletown area, Lake County, California: U.S. Geol. Survey Water-Supply Paper 1297, 83 p., 1955.

The present and potential ground-water development in nine large valleys and in several small valleys are described.

URsic, S. J.

(and Thames, J. L.). An inexpensive rain gage: Jour. Soil and Water Conserv., v. 13, no. 5, p. 231-232, 1958.

A gage made from a no. 10 can was found to produce reliable results.

\section{U.S. Army Corps of Engineers.}

1. Waves and wind tides in shallow lakes and reservoirs: U.S. Army Corps Engineers, Jacksonville Dist., Proj. CW-167, 46 p., June 1955.

General summary of the waves and wind-tide investigation conducted on Lake Okeechobee is given.

2. Report on storms and floods of spring 1947 in Missouri, Iowa, and adjoining States: U.S. Army Corps Engineers, Missouri River Div., 3 v., May 1955.

The report contains text and appendices on hydrology, meteorology, and storm studies.

3. Lysimeter studies of snowmelt: U.S. Army Corps Engineers, North Pacific Div., Snow Inv. Research Note 25, 41 p., Mar. 1955.

Runoff from an unforested 600-square foot snow-lysimeter area is used as a measure of snowmelt quantities. The component melts due to radiation, convection, and condensation are computed from measured meteorological parameters and compared with the gaged runoff. Appendix: Theory of turbulent exchange.

4. Coordination of flood-volume-frequency statistics: U.S. Army Corps Engineers, Sacramento Dist., Proj. CW-151, Rept. no. 2, July 1955.

5. Streamflow volume-duration-frequency studies: U.S. Army Corps Engineers, Wash. Dist. Tech. Rept., no. 1, 1955.

The report emphasizes runoff-duration-frequency of flood flows. Data are included. 6. Summary report of the snow investigations; snow hydrology: U.S. Army

Corps Engineers, North Pacific Div., 437 p., June 1956.

The report summarizes results of work of Cooperative Snow Investigations and indicates applications. It contains data on the snow laboratories, precipitation and snow accumulation, melting of the snowpack, snowmelt indexes, areal snow cover, effect of snowpack condition on runoff, hydrograph synthesis, design flood determination, seasonal runoff forecasting, and reservoir regulation. 
7. Flood volume frequency statistics for Pacific Coast streams: U.S. Army Corps Engineers, Sacramento Dist., Proj. CW-151, Rept. no. 3, Mar. 1956.

8. Report on sedimentation for period Dec. 1949-April 1951: U.S. Army Corps Engineers, Seattle, 29 p., Mar. 1956.

Data and analyses at three sites are given.

9. Development and test performance of radioisotope-radiotelemetering snow-gage equipment: U.S. Army Corps Engineers, South Pacific Div., Proj. CWI-170, 47 p., Apr. 1956.

The report describes the theory, construction, testing, and performance of the equipment.

10. Suspended sediment in the Missouri River: U.S. Army Corps Engineers, Missouri River Div., 1957.

The report summarizes suspended sediment records for the water years 1949 through 1954 for all stations in the Missouri River basin where regular suspended sediment sampling has been performed by the Corps of Engineers.

11. Ten year storm precipitation in California and Oregon coastal basins: U.S. Army Corps Engineers, Sacramento Dist., Proj. CW-151, Rept. no. 4, May 1957.

12. Telemetering networks: U.S. Army Corps Engineers, Ohio River Div., Proj. CW-173, Tech. Bull. no. 1, June 1957.

The report discusses the general considerations for a telemetering network, equipment development, results of field tests, and recommendations.

13. Long-duration runoff volumes: U.S. Army Corps Engineers, Sacramento Dist., Proj. CW-151, Rept. no. 5, July 1958.

14. Report of sedimentation resurvey, Canton Reservoir, North Canadian River, New Mexico, Texas, and Oklahoma, 1953, Arkansas River Basin: U.S. Army Corps Engineers, Tulsa. Dist. Rept., 24 p., 1958.

The report describes basin, reservoir, method of survey, and amount and types of sediment deposited.

U.S. Bureau of Reclamation.

1. Report on Esquatzel Coulee channel as a project wasteway, Columbia Basin Project, Washington: Comm. Office, Denver, Colo., 221 p., Mar. 1955.

The stable channel problems associated with using the Esquatzel Coulee channel as the main drain from irrigated lands are outlined, and a solution is presented.

2. Method of estimating the magnitude and occurrence of return flow: Comm. Office, Denver, Colo., 8 p., June 1955.

This study derives a set of design flow-duration curves from an analysis of the return flows of the existing North Platte and Riverton Projects.

3. Step method for computing total sediment load by the modified Einstein procedure: U.S. Bur. Reclamation, Sediment Sec., 10 p., July 1955.

A simplified computational outline is presented, for use by personnel not familiar with the theory behind this precedure, for computation of total sediment loads.

4. Resistivity field tests in the Othello Area-Columbia Basin Project, Washington:

Comm. Office, Denver, Colo., U.S. Bur. Reclamation, Geol. Rept. G-129, 3 p., June 24, 1955.

Field tests of the resistivity method indicate that, where drilling is available to establish control, the resistivity method will, in many cases, provide an economical means of supplementing other types of subsurface investigations in connection with drainage problems.

5. Geophysical investigations in connection with ground-water studies in the East Shore Area-Weber Basin Project, Utah: Comm. Office, Denver, Colo., 
Geol. Rept. G-130, 19 p., Jan. 16, 1956.

Geophysical investigations using the seismic reflection method were employed to measure the depth, thickness, and continuity of aquifers for use in a comprehensive ground-water study of the East Shore Area.

6. Erosion studies on sandstone through which the Glen Canyon Dam diversion tunnels will pass-Glen Canyon Dam-Colorado River Storage Project: Comm. Office, Denver, Colo., Hydraulic Lab. Rept. HYD-423, 5 p., Dec. 24, 1956.

The studies determine the resistance to erosion by flowing water of the sandstone material from the damsite.

7. Erosion studies on the earth material from the site of the proposed unlined emergency spillway at Foss Dam, Washita Project, Oklahoma: Comm. Office, Denver, Colo., Hydraulic Lab. Rept. HYD-426, 3 p., Oct. 22, 1956.

The studies determine the general erosion characteristics of a firm lean, layered clay, through which a proposed unlined emergency spillway would pass.

8. Preliminary evaporation reduction studies-Lake Hefner, Oklahoma City, Oklahoma: Comm. Office, Denver, Colo., 18 p., 1957.

Results of a test of the effect of hexadecanol on the biological and limnological factors in a 6-acre lake are reported.

9. Progress report of canal erosion and tractive force study, lower-cost canal lining program: Comm. Office, Denver, Colo., Gen. Rept. 21, 14 p., Mar. 1, 1957.

A test flume with a soil seepage section is used to determine the effectiveness of bentonite in preventing canal seepage losses.

10. Water quality studies with hexadecanol, Kids Lake, Oklahoma City, Oklahoma. Report of Committee of Collaborators; Comm. Office, Colo., Apr. 15, 1957:

The Kids' Lake study failed to disclose any major detrimental effect on water quality that would preclude the use of hexadecanol for large scale evaporation reduction investigations.

11. Determination of the presence and degree of compression of a monomolecular layer using indicator oils: Comm. Office, Denver, Colo., U.S. Bur. Reclamation, Chem. Eng. Lab. Rept. SI-13, 5 p., June 3, 1957.

Laboratory and field tests were made to develop a feasible method of applying and maintaining a monomolecular layer of hexadecanol. The first series of tests show that indicator oils gave consistant and reasonable measurements of the hexadecanol film pressure.

12. Guide for computing water-surface profiles: U.S. Bur. Reclamation, Sediment Sec., 164 p., Nov. 1957.

This guide is a compilation of various methods of computing water surface profiles in natural channels and was designed primarily to aid field personnel in the computation of tail-water and back-water curves.

13. The effect of surface tension upon the flotation of small beads of hexadecanol: Comm. Office, Denver, Colo., U.S. Bur. Reclamation, Chem. Eng. Lab. Rept. SI-8, 12 p., Aug. 1, 1957.

Laboratory and analytical studies indicate that the reason for hexadecanol in flake form outperforming that in beaded form is the near submergence of the beads by surface tension.

14. Reservoir evaporation reduction with monomolecular and similar films-progress report March 1955 through March 1956: Comm. Office, Denver, Colo., Chem. Eng. Lab. Rept. SI--9, 36 p., Jan. 29, 1957.

The report presents an annotated bibliography of references relating to evaporation control using surface films and reports progress on pilot tests using cetyl alcohol and 
on screening tests using various film-producing agents.

15. Preliminary toxicity studies with hexadecanol, reservoir evaporation reduction: Comm. Off., Denver, Colo., Chem. Eng. Lab. Rept. SI-10, 14 p., Mar. 15, 1957.

Laboratory tests were made of the effect of hexadecanol on fish life, plant life, wild fowl, and gas transfer through the film. Tests showed no acute gross or severe toxicity to fish, plants, or wild fowl, and no deleterious effects upon the diffusion of oxygen or carbon dioxide through the water surface.

16. Density measurement of saturated submersed sediment by gamma ray scattering: Comm. Office, Denver, Colo., Chem. Eng. Lab. Rept. SI-11, 34 p., Mar. 25, 1957.

Laboratory and field tests were made using a probe containing cobalt-60 as a source of gamma rays and a self-reading ionization chamber for the detector. Results indicate that the dry density of submersed saturated sediments can be adequately determined by utilizing the phenomenon of gamma-ray scattering, and that the equipment used in this investigation could, with certain minor modifications, be used to measure the density of the upper few feet of submersed saturated sediments. 17. Reservoir evaporation control-screening tests on monolayers and duplex films: Comm. Office, Denver, Colo., Chem. Eng. Lab. Rept. SI-12, 12 p., July 8, 1957.

The results of screening tests indicate that 5 of the oils and 4 of the surface-active agents tested appear worthy of additional tests both alone and in combination at various concentrations.

18. Hydraulic flume tests using bentonite to reduce seepage. Comm. Office, Denver, Colo., Hydraulic Lab. Rept. HYD-417, 9 p., Mar. 8, 1957.

A test flume with a soil seepage section is used to determine the effectiveness of bentonite in preventing canal seepage losses.

19. Hydraulic model studies to develop a sediment control arrangement for Angostura Diversion-Middle Rio Grande Project, New Mexico: Comm. Office, Denver, Colo., Hydraulic Lab. Rept. HYD-419, 12 p., Feb. 21, 1957.

The report presents a study of the overhanging sill, curved guide wall, and vortex tube methods of minimizing sediment intake into a cansl.

20. Design, assembly, and use of a portable vane shear tester: Comm. Office, Denver, Colo., Hydraulic Lab. Rept. HYD-434, 5 p., June 21, 1957.

The report describes a vane shear tester developed to determine the in-place resistance to shear of soils near the bottom of unlined canals as part of a program to relate shear resistance and erosion resistance of earth canals.

21. (and California Department of Water Resources). 1957 joint hydrology study, Sacramento River and Sacramento-San Joaquin Delta: Calif. Dept. Water Resources, 353 p., 1958.

22. Carbohydrate reserves in tamarisk (salt cedar) - progress report No. 1, July 1957 through July 1958: Comm. Office, Denver, Colo., U.S. Bur. Reclamation, Chem. Eng. Lab. Rept. SI-19, 19 p., Oct. 17, 1958.

The Task Force, Phreatophyte Subcommittee, Pacific Southwest Inter-Agency Committee decided that a limited study on the seasonal trend of carbohydrate reserves in tamarisk would be worthwhile as a possible guide in the timing of control methods. Initial analysis of data gathered thus far, indicates there are well-defined periods of low carbohydrate reserves in roots and stems of tamarisk.

23. Interim report, total sediment transport program, Lower Colorado River basin: U.S. Bur. Reclamation, Sediment Sec., 175 p., Jan. 1958.

A sampling program to determine total-sediment load transport at selected locations 
was initiated in July and September 1955 in two reaches of the lower Colorado River. This report analyzes the data and computation results (Modified Einstein computations), arrives at preliminary figures on sediment quantities, and recommends revisions in the sediment sampling program.

24. Sedimentation resurvey of Guernsey Reservoir, 1957, North Platte Project, Wyoming and Nebraska: U.S. Bur. Reclamation, Sediment Sec., 65 p., Aug. 1958.

The report presents the results of an investigation of reservoir sedimentation in Guernsey Reservoir near Guernsey, Wyo. Total loss of reservoir capacity during the period 1927-57 was 39.3 percent with an average sediment yield rate of 0.23 acre feet per square mile per year to the reservoir. Other results of the resurvey are presented and discussed.

U.S. Commission on Organization of the Executive Branch of the Government (1953-55).

Water resources and power; a report to the Congress: Washington, U.S. Govt. Printing Office, 2 v. in 1, 1955.

The report of the task force includes (1) the magnitude of the problem, national water policies and administrative organization problems common to the four major Federal activities, (2) reclamation and irrigation, (3) flood control, (4) navigation, and (5) power. Separate statements of the commissioners are included.

U.S. Department of Agriculture.

Water, The Yearbook of Agriculture: U.S. Dept. Agriculture, 723 p., 1955.

This book contains 96 individual articles on the need for water, sources of water, and the relation of water to soil, vegetation, and wildlife. Many are listed separately in this bibliography.

U.S. Department of the Army.

Flood prediction techniques: U.S. Dept. Army Tech. Bull., no. 5-550-3, Washington, U.S. Govt. Printing Office, 215 p., 1957.

U.S. Federal Power Commission.

Hydroelectric power resources of the United States, developed and undeveloped, 1957: U.S. Federal Power Comm. F.P.C. P-32, 196 p., Jan. 1, 1957.

The report presents compilations and summaries of data as of Jan. 1, 1957, on the water resources of the United States as related to the development of hydroelectric power. The compilations bring together data on existing hydroelectric plants and undeveloped power sites grouped and arranged by major drainages and river basins and by geographic divisions and States.

U.S. Geological Survey.

1. Floods of April 1952 in the Missouri River basin: U.S. Geol. Survey WaterSupply Paper 1260-B, p. 49-302, 1955.

The floods were the greatest ever observed in parts of the basin and were caused by rapid melting of an unusually heavy accumulation of snow. Detailed records of stages and discharges and information on damages are given.

2. Floods of 1952 in the basins of the Upper Mississippi River and Red River of the

North: U.S. Geol. Survey Water-Supply Paper 1260-C, p. 303-529, 1955.

These floods were generally smaller than those of 1881. Some were larger and some smaller than the floods of 1951. Detailed records of stages and discharges are given. 3. Quality of surface water for irrigation, Western United States, 1951: U.S. Geol. Survey Water-Supply Paper 1264, 153 p., 1954 [1955].

This paper contains records of chemical analyses, other physical measurements, and discharge at 78 stations west of the Mississippi River.

4. Compilation of records of surface waters of the United States through September 
1950, part 7, lower Mississippi River basin: U.S. Geol. Survey Water-Supply Paper 1311, 606 p., 1955.

The report contains records of monthly and yearly mean discharges, monthly and yearly runoff, and yearly extremes.

5. Compilation of records of surface waters of the United States through September 1950, part 9, Colorado River basin: U.S. Geol. Survey Water-Supply Paper 1313, 749 p., 1954 [1955].

The report contains records of monthly and yearly mean discharges, monthly and yearly runoff, and yearly extremes.

6. Compilation of records of surface waters of the United States through September 1950, part 12, Pacific slope basins in Washington and upper Columbia River

basin: U.S. Geol. Survey Water-Supply Paper 1316, 592 p., 1955.

The report contains records of monthly and yearly mean discharges, monthly and yearly runoff, and yearly extremes.

7. Quality of surface waters for irrigation, Western United States, 1952: U.S. Geol. Survey Water-Supply Paper 1362, 179 p., 1955.

Records of chemical analyses, other physical measurements, and discharge are given for 78 irrigation network stations west of the Mississippi River.

8. Compilation of records of surface waters of the United States through September 1950, part 13, Snake River basin: U.S. Geol. Survey Water-Supply Paper 1317, 566 p., 1956.

The report contains records of monthly and yearly mean discharges, monthly and yearly runoff, and yearly extremes.

9. Floods of June 1953 in northwestern Iowa: U.S. Geol. Survey Water-Supply Paper 1320-A, 68 p., 1955 [1956].

The magnitude and areal extent of the June floods are unmatched. The floods are described, and detailed records of stages and discharges are given.

10. Floods of August 1955 in the Northeastern States: U.S. Geol. Survey Circ. 377,76 p., 1956.

This is an advance report describing the floods and presenting detailed stage and discharge data.

11. Floods of December 1955-January 1956 in Far-Western States; peak discharges: U.S. Geol. Survey Cire. 380, 15 p., 1956.

A compilation of peak discharges is given.

12. Floods of April-June 1952 in Utah and Nevada: U.S. Geol. Survey WaterSupply Paper 1260-E, p. 577-686, 1957.

Record floods resulted from melting of the heaviest snow cover ever recorded. Flood damages are described and detailed stage and discharge records listed.

13. Compilation of records of surface waters of the United States through 1950, part 3-A, Ohio River basin except Cumberland and Tennessee River basins: U.S. Geol. Survey Water-Supply Paper 1305, 652 p., 1957.

The report contains records of monthly and yearly mean discharges, monthly and yearly runoff, and yearly extremes.

14. Floods of May-June 1953 in Missouri River basin in Montana: U.S. Geol. Survey Water-Supply Paper 1320-B, 153 p., 1957.

The floods are described and detailed records of stages and discharges are given.

15. Compilation of records of quantity and quality of surface waters of Alaska through September 1950: U.S. Geol. Survey Water-Supply Paper 1372, 262 p., 1957.

This report contains all published streamflow records for Alaska prior to 1946 
summarized on a monthly and yearly basis; records of daily and monthly discharge, and miscellaneous discharge measurements, which were collected during the years 1946-50; and records of chemical quality and temperature for the period 1948-50. 16. Quality of surface waters for irrigation, Western United States, 1953: U.S. Geol. Survey Water-Supply Paper 1380, 203 p., 1957.

Records of chemical analyses, other physical measurements, and discharge are given for 84 irrigation network stations.

17. Summary of floods in the United States during 1951: U.S. Geol. Survey WaterSupply Paper 1227-D, p. 279-298, 1957 [1958].

The report contains a short description by States and a table of flood stages and discharges.

18. Floods of $1950-51$ in the Catskill Mountain Region, New York: U.S. Geol. Survey Water-Supply Paper 1227-C, p. 201-275, 1958.

Two notable floods occurred within a period of 4 months. Descriptions, detailed tables of stages and discharges, and a section on flood frequency are given. Two previous floods in the region are also described.

19. Compilation of records of surface waters of the United States through September 1950, part 2-A, South Atlantic slope basins, James River to Savannah River:

U.S. Geol. Survey Water-Supply Paper 1303, 325 p., 1958.

The report contains records of monthly and yearly mean discharges, monthly and yearly runoff in inches, and yearly extremes.

20. Compilation of records of surface waters of the United States through September 1950, part 3-B, Cumberland and Tennessee River basins: U.S. Geol. Survey Water-Supply Paper 1306, 353 p., 1958.

The report contains records of monthly and yearly mean discharges, monthly and yearly runoff, and yearly extremes.

21. Compilation of records of surface waters of the United States through September 1950, part 4, St. Lawrence River basin: U.S. Geol. Survey Water-Supply Paper 1307, 397 p., 1958.

The report contains records of monthly and yearly mean discharges, monthly and yearly runoff, and yearly extremes.

22. Compilation of records of surface waters of the United States through September 1950, part 6-B, Missouri River basin below Sioux City, Iowa: U.S. Geol. Survey Water-Supply Paper 1310, 619 p., 1958.

The report contains records of monthly and yearly mean discharges, monthly and yearly runoff, and yearly extremes.

23. Compilation of records of surface waters of the United States through September 1950, part 14, Pacific slope basins in Oregon and lower Columbia River basin:

U.S. Geol. Survey Water-Supply Paper 1318, 550 p., 1958.

The report contains records of monthly and yearly mean discharges, monthly and yearly runoff, and yearly extremes.

24. Quality of surface waters for irrigation, Western United States, 1954: U.S.

Geol. Survey Water-Supply Paper 1430, 205 p., 1958.

Records of chemical analyses, other physical measurements, and discharge are given for 82 irrigation network stations west of the Mississippi River.

25. Quantity and quality of surface waters of Alaska, October 1950 to September

1953: U.S. Geol. Survey Water-Supply Paper 1466, 243 p., 1958.

The report contains the results of measurements of the flow and the chemical and physical quality of streams.

26. Quantity and quality of surface waters of Alaska, October 1953 to September 1956: U.S. Geol. Survey Water-Supply Paper 1486, 229 p., 1958. 
The report contains the results of measurements of the flow and the chemical and physical quality of the streams.

U.S. Inter-Agency Committee on Water Resources.

1. Inventory of published and unpublished chemical analyses of surface water in Western United States, 1947-55: Washington, U.S. Govt. Printing Office, Notes on hydrologic activities, Bull. 9, 113 p., 1956.

The inventory includes references to all available analyses of surface waters west of the Mississippi River, exclusive of the main stem of the Mississippi.

2. Summary of reservoir sedimentation surveys made in the United States through 1953: U.S. Inter-Agency Comm. Water Resources, Sedimentation Bull., no. 6, U.S. Govt. Printing Office, 47 p., 1957.

Information relative to location, drainage area, rates of sediment accumulation, and related information of general interest is given for 704 reservoirs.

3. The development and calibration of the visual-accumulation tube: U.S. Inter-Agency Comm. Water Resources, Subcomm. Sedimentation, Rept. no. 11, 109 p., 1957.

This report describes the visual-accumulation-tube method and apparatus for determining the size frequency distribution of sand samples on the basis of fall velocity or fall diameter. Tests to calibrate the method for use with natural sediments are described.

4. Some fundamentals of particle size analysis: U.S. Inter-Agency Comm. Water Resources, Subcomm. Sedimentation, Rept. no. 12, 55 p., 1957.

Some basic concepts, definitions, and relations essential to particle size analysis are discussed, fall velocity is emphasized, and techniques which may be useful in further studies are described.

5. Proposed practices for economic analysis of river basin projects: Washington,

U.S. Govt. Printing Office, 56 p., 1958.

An interim revision of the May 1950 report is given.

U.S. Presidential Advisory Committee on Water Resources Policy.

Water resources policy: Washington, U.S. Govt. Printing Office, 35 p., 1955.

This is a report to the President.

U.S. Soll Conservation Service.

1. How to recognize erosion in the northeast: U.S. Dept. Agriculture, Agriculture Inf. Bull., no. 27, 16 p., 1956.

Different types of erosion are illustrated in the report.

2. Water rights and soil and water conservation: U.S. Dept. Agriculture PA-306, 8 p., 1957.

Water rights relating to storage, detention, diversion, use, and disposal must be considered in planning soil and water conservation measures.

3. Water facts: U.S. Dept. Agriculture PA-337, 1957.

Sources, supply, needs, uses, losses, floods, and conservation are described.

4. Farm pond survey-Texas, July 1957: U.S. Dept. Agriculture, Soil Conserv.

Service, Temple, Tex., 12 p., 1958.

The total number, average surface area, average drainage area, and average depth of ponds were determined in order to define the effects of these ponds on downstream water yields. This report describes methods used, areas involved, findings, and a few conclusions.

U.S. Tennessee Valuey Authority.

Influences of reforestation and erosion control upon the hydrology of the Pine Tree 
Branch watershed, 1941 to 1950: U.S. TVA Tech. Mon., no. 86, 95 p., 1955. Investigations were conducted on the 88-acre watershed over a 10 -year period to determine the effects of reforestation and erosion control measures on the hydrology of the watershed. Definite changes are reported.

U.S. Weather Bureau.

1. Rainfall intensity-duration-frequency curves. For selected stations in the United States, Alaska, Hawaiian Islands, and Puerto Rico: U.S. Weather Bur., Tech. Paper, no. 25, 53 p., 1955.

Curves of rainfall intensity versus duration for return periods of $2,5,10,25,50$ and 100 years are presented for each of 203 U.S. Weather Bureau first-order stations. 2. Hurricane rains and floods of August 1955, Carolinas to New England: U.S.

Weather Bur. Tech. Paper, no. 26, 148 p., 1956.

An analysis is presented of the meteorological conditions which produced the heavy rains associated with hurricanes Connie and Diane together with a compilation of the basic hydrometeorological data for the affected areas, including isohyetal maps, mass rainfall curves, and river-stage hydrographs. Hourly and daily amounts of precipitation recorded at stations from the Carolinas to New England during the month of August 1955 are tabulated.

3. Rainfall intensities for local drainage design in Western United States: U.S.

Weather Bur. Tech. Paper, no. 28, 46 p., 1956.

The report presents isopluvial maps of precipitation amounts for a return period of 2 years for the area west of $105^{\circ}$ for durations of 1, 6, and 24 hours. Maps of the corresponding 100-year to 2-year ratios are included together with nomograms for obtaining rainfall values for return periods from 1 to 100 years and durations from 20 minutes to 24 hours.

4. Monthly normal temperatures, precipitation, and degree days: U.S. Weather Bur. Tech. Paper no. 31, 39 p., 1956.

Tabulated values are given of 1921-50 normals of temperature, precipitation and degree days for U.S. stations.

5. Survey of meteorological factors pertinent to reduction of loss of life and property in hurricane situations: U.S. Weather Bur., Natl. Hurricane Proj. Rept., no. 5,87 p., 1957.

The report summarizes and discusses hurricane frequencies in coastal areas, correlation of excessive rainfall and hurricane characteristics and tidal effects, and warning plans.

6. Rainfall intensity-frequency regime: U.S. Weather Bur. Tech. Paper, no. 29, Part I-The Ohio Valley, 44 p., 1957; Part II - Southeastern United States, 51 p., 1958; Part III-The Middle Atlantic Region, 38 p., 1958.

Isopluvial maps are presented showing precipitation amounts for the 2-year return period and for durations of 1,6 , and 24 hours. Charts and nomograms are included to obtain precipitation values for return periods from 2 to 100 years and for durations of 1 to 24 hours. Depth-area curves enable adjustment of the point rainfall data to areas up to 400 square miles.

7. Maximum station precipitation for 1, 2, 3,6, 12, and 24 hours: U.S. Weather Bur. Tech. Paper, no. 15, Part XI-North Carolina, 81 p., 1955; Part XII-Oregon, 106 p., 1955; Part XIII-Kentucky, 71 p., 1955; Part XIV-Louisiana, 54 p., 1955; Part XV-Alabama, 54 p., 1955; Part XVI-Pennsylvania, 146 p., 1956; Part XVII-Mississippi, 70 p., 1956; Part XVIII-West Virginia, 49 p., 1956; Part XIX-Tennessee, 82 p., 1956; Part XX-Indiana, 97 p., 1956; Part XXI-Illinois, 99 p., 1958; Part XXII-Ohio, 137 p., 1958. 
A tabulation' is given of the highest observed values of record for each month at every recording-gage station with at least 10 years of record.

8. Rainfall and floods of April, May, and June 1957 in the South-Central States: U.S. Weather Bur. Tech. Paper, no. 33, 350 p., 1958.

The report analyzes the meteorological conditions which produced these heavy rains, presents basic hydrometeorological data, and includes discussion of the use of radar in flood forecasting.

Vallentyne, J. R.

Principles of modern limnology: Am. Scientist, v. 45, no. 3, p. 218-244, 1957.

The occurrences within a lake are discussed in terms of principles and generalities. The paper is divided into physics and metabolism.

van Bavel, C. H. M. See also Veihmeyer, F. J., 1.

1. (and Verlinden, F. J.). Agricultural drought in North Carolina: N.C. Agr. Expt. Sta., Tech. Bull., no. 122, 60 p., 1956.

This paper reports a study to determine the number of days of drought in past seasons in North Carolina, and from this information to estimate the expected number of days of drought in future seasons.

2. Estimating soil moisture conditions and time for irrigation with the evapotranspiration method: U.S. Dept. Agriculture, ARS 41-11, 16 p., 1956.

This report presents information which is needed to estimate soil moisture content through the use of climatological data.

3. (and Underwood, Newton, and Swanson, R. W.). Soil moisture measurement by neutron moderation: Soil Sci., v. 82, no. 1, p. 29-41, 1956.

A report is given on the use of a portable instrument to measure soil moisture by measurement of slow neutron density in soils.

4. (and Carreker, John R.). Agricultural drought in Georgia: U.S. Dept.

Agriculture, Tech. Bull. N. S. 15, 40 p., 1957.

A study of evapotranspiration and precipitation in Georgia justifies the conclusion that average soil moisture conditions in Georgia are not adequate to insure maximum crop production. This inadequacy in dry years becomes quite serious, and occasionally it reaches near disaster conditions.

5. (and Forrest, L. A., and Peele, T. C.). Agricultural drought in South Carolina:

U.S. Dept. Agriculture, Bull. 447, 36 p., 1957.

The factors of temperature, humidity, sunshine percentage, extraterrestrial radiation, windspeed, precipitation, and the capacity of the soil to store water in a form available for plant growth have all been considered in determining the agricultural drought probabilities in South Carolina.

6. (and Lillard, J. H.). Agricultural drought in Virginia: Va. Agr. Expt. Sta., Tech. Bull. 128, 38 p., 1957.

The probability of droughts throughout Virginia is based on past climatic records. 7. Measurement of soil moisture content by the neutron method: U.S. Dept. Agriculture, ARS 41-24, 29 p., 1958.

The method and the equipment are described, and the advantages and limitations of the method as well as pertinent information on precision and calibration are presented.

van der Goot, Herbert A. See Laverty, F. B., 1.

Van Dersal, William R. See Graham, E. H.

Van Doren, C. A.

(and Bartelli, L. J.). A method of forecasting soil loss: Agr. Eng., v. 37, no. 5, p. 335-341, 1956. 
A method for determining soil loss from various Illinois soils under different management and conservation programs is presented.

VAN Horn, O. B.

Evolution in derivation of seasonal streamflow forecast procedures: Western Snow Conf. Proc., p. 82-90, Apr. 1958.

Experiences in developing forecast equations by an electronic computer are described.

van Hylckama, T. E. A. See also Beaumont, R. T., 2; Remson, I., 4.

1. The water balance of the earth: Lab. Climatology, Pubs. Climatology, v. 9, no. 2, p. 53-117, 1956.

2. Modification of the water balance approach for basins within the Delaware Valley: Lab. Climatology, Pubs. Climatology, v. 11, p. 271-302, 1958.

Van Lare, Frank E. See Milmoe, W.

Vanlier, K. E. See also Deutsch, M., 2.

1. (and Deutsch, Morris). Reconnaissance of the ground-water resources of Chippewa County, Michigan: Mich. Geol. Survey Div. Rept., no. 17, 56 p., 1958.

The report summarizes the general occurrence, availability, quantity, and quality of ground water.

2. (and Deutsch, Morris). Reconnaissance of the ground-water resources of Mackinac County, Michigan: Mich. Geol. Survey Div. Rept., no. 19, 82 p., 1958.

The report summarizes the sources, occurrence, availability, and geochemistry of the ground water in the Peninsula.

Vanoni, Vito A. See also Carey, W. C.; Liu, H. K., 1.

(and Brooks, Norman H.). Laboratory studies of the roughness and suspended load of alluvial streams: Calif. Inst. Technology Sedimentation Lab. Rept.,no. E-68, 121 p., 1957.

Variation of the friction factor caused by changing bed configuration and the damping effect of suspended sediment was studied in the laboratory. The relation between the sediment transportation rate and the hydraulic variables was also investigated. Laboratory data are compared with similar data for natural streams, and literature on resistance of sediment-laden streams is critically reviewed.

Van't Hul, Arthur. See Nace, R. L., 2.

van't Woudt, Bessel D.

1. On a hillside moisture gradient in volcanic ash soil, New Zealand: Am. Geophys. Union Trans., v. 36, p. 419-424, 1955.

Data on a moisture gradient in the surface soil on a slope of about $30^{\circ}$ and about 50 feet long are given.

2. Observations of the efficiency of sub-irrigation in heavy soils: Am. Geophys. Union Trans., v. 37, p. 588-592, 1956.

Results of a field experiment indicate that subirrigation in heavy soils can be successful if supplemented by natural rain.

VARNey, Gilbert L.

Factors affecting runoff from forest land under extreme climatic conditions: Jour. Soil and Water Conserv., v. 11, no. 3, p. 132-136, 1956.

Examples are given of runoff from several areas under heavy hurricane precipitation.

VAUGHN, JaMES C.

(and Schmidt, Robert W., Tenny, Alfred, and Shor, Arthur). Studies of radio- 
activity in the Chicago water supply: Am. Water Works Assoc. Jour., v. 50, no. 5, p. 581-589, 1958.

Chicago Bureau of Water has monitored water for radioactivity since 1950. The three phases are continuous monitoring, regular sampling and counting raw and treated water, and sampling and counting of precipitation. No high activity has been found but changes have been observed.

Veatch, F. M. See Codd, A. R.

VeIHMEYer, F. J.

1. (and Hendrickson, A. H.). Does transpiration decrease as the soil moisture decreases?: Am. Geophys. Union Trans., v. 36, p. 425-428, 1955.

Tests on trees grown in tanks and in fields indicate that the rate of moisture extraction from the soil is not influenced by the amount of water in the soil so long as the latter is above the permanent wilting percentage. (Discussion by E. A. Colman, C. H. M. van Bavel, R. B. Marston, H. A. Wadsworth, Steven L. Mech, A. R. Croft, C. M. Woodruff, N. L. Stoltenberg, L. D. Doneen, J. R. Mather, Sterling A. Taylor, Leon Lassen and Howard W. Lull and Bernard Frank, and Paul J. Kramer.)

2. (and Hendrickson, A. H.). Rates of evaporation from wet and dry soils and their significance: Soil Sci., v. 80, no. 1, p. 61-67, July 1955.

A laboratory method of determining the rate of evaporation is described. It is concluded that the rate is as rapid from dry soil as from wet soil down to the permanent wilting percentage.

Verlinden, F. J. See van Bavel, C. H. M., 1.

Verma, Ramjee P. See Ippen, A. T., 1.

Verville, George J.

Geology, mineral resources, and ground-water resources of Elk County, Kansas: Kans. Geol. Survey Rept. 14 [Univ. Kans. Pub.], 56 p., 1958.

Viparelli, Michele. See Straub, L. G., 3.

Virginia Advisory Legislative Council.

Water resources of Virginia; report to the Governor and General Assembly of Virginia: Va. Advisory Legislative Council, Div. Purchase and Printing, House Doc. 12, 139 p., 1955.

Virginia Legislative Council.

Water resources in Virginia; a report: Va. Legislative Council, Div. Purchase and Printing, House Doc. 28, 45 p., 1958.

Visher, F. N. See also Rapp, J. R.

Geology and ground-water resources of Quinn River valley, Humboldt County, Nevada: Nev. State Engineer Bull. 14, 55 p., 1957.

VISHER, STEPHEN S.

Climatic contrasts in the United States: Sci. Monthly, v. 81, no. 3, p. 115-122, 1955.

Temperature, precipitation, evaporation, wind, and sunshine contrasts are described and shown on maps of the United States.

VISSER, S. W.

The 27-day period in United States temperatures: Am. Geophys. Union Trans., v. 39, p. 835-844, 1958.

Daily maximum temperatures during two series of regular 27-day periods are harmonically analyzed. 


\section{Vogel, Herbert D.}

An engineer's view of TVA: Mil. Engineer, v. 48, no. 322, p. 87-93, 1956.

The aims, purposes, and accomplishments of TVA are presented.

Volk, Donald J. See White, G. F., 2.

von Buttlar, Haro.

1. (and Wendt, Immo). Ground-water studies in New Mexico using tritium as a tracer: Am. Geophys. Union Trans., v. 39, p. 660-668, 1958.

Inferences as to the rate of flow of aquifers and the size of recharge reservoirs can be made using tritium. The feasibility of a proposed method was tested.

2. Investigating ground water by analysis of atmospheric tritium: Am. Water Works Assoc. Jour., v. 50, no. 11, p. 1533-1538, 1958.

The method is based on the radioactivity of water due to cosmic ray action and H-bomb explosions.

Von Eschen, G. F.

Climatic trends in New Mexico: Weatherwise, v. 11, no. 6, p. 191-195, 1958.

Records indicate that northeastern New Mexico has been getting progressively drier and warmer for many years.

Vorhis, Robert C. See also Tychsen, P. C.

Bibliography of publications relating to ground water prepared by the Geological Survey and cooperating agencies, 1946-55: U.S. Geol. Survey Water-Supply Paper 1492, 203 p., 1957.

WADLETGH, C. H.

(and Wilcox, L. V., and Gallatin, M. H.). Quality of irrigation water: Jour. Soil and Water Conserv., v. 11, no. 1, p. 31-33, 1956.

This report is limited to discussion of water quality as affected by naturally occurring solutes.

Wadsworth, H. A. See Veihmeyer, F. J., 1.

Wagner, Kenneth. See Kurz, H.

Watte, H. A.

(and Thomas, H. E.). Effect of current drought upon water supplies in Cedar City

Valley, Utah: Am. Geophys. Union Trans., v. 36, p. 805-812, 1955.

Ground-water levels are lowest of record but resources may not be overdeveloped.

Waldorf, S. K. See Swengel, R. C.

Walker, Eugene H.

1. Reserves of ground water in Iowa: Am. Water Works Assoc. Jour., v. 48, no. 5, p. 499-510, 1956.

A description of the resources and present use is given.

2. Reservoir capacity of Mississippian limestones in the Hopkinsville quadrangle, Kentucky: Geol. Soc. America Bull., v. 67, p. 1431-1440, 1956.

The ground-water reservoir stores less than an inch of water in the interval between high and low water levels (based on well and stream records).

3. Ground-water resources of the Hopkinsville quadrangle, Kentucky: U.S. Geol. Survey Water-Supply Paper 1328, 98 p., 1956.

Ground water is obtained almost wholly from wells drilled in limestone. Yield is highly variable. Recharge, discharge, fluctuation of water levels, and contamination are described.

4. The deep channel and alluvial deposits of the Ohio Valley in Kentucky: U.S. Geol. Survey Water-Supply Paper 1411, 25 p., 1957. 
The reportisa compilation of information on the deposits that form one of the most productive aquifers in Kentucky.

WALKer, G. E. See Cleary, E. J., 3.

WALKER, RAY.

Effects of 1957 storms on Oklahoma watersheds: Jour. Soil and Water Conserv., v. 13 , no. 5, p. 223-225, 1958.

Benefits from upstream flood prevention works were shown by the effects of a 100 year frequency storm.

Walker, Theodore R. See Bergstrom, R. E., 2.

Walker, W. H. See Pree, H. L.

WALKINSHAW, W. M.

Ground-water problems in south-western Ontario: Eng. Jour., v. 39, no. 2, p. 120-126, 1956.

The author discusses the present situation, reviews future developments and demands, and suggests various approaches towards the resolution of the inherent difficulties.

\section{Wallace, Donatd S.}

Eastern water shortage and drought problems, 1954 drought in Virginia: Am. Water Works Assoc. Jour., v. 47, no. 3, p. 222-225, 1955.

The report presents part of a symposium describing effects of the drought on municipal supplies.

WALSh, KenNETH J.

New meteorological and snow studies in the Central Sierra: Western Snow Conf. Proc., p. 43-45, Apr. 1957.

Meteorological and snow physics studies are being resumed at the Central Sierra Snow Laboratory by the U.S. Forest Service.

\section{W Alters, KenNeth $\mathbf{L}$.}

Geology and ground-water resources of Rawlins County, Kansas: Kans. Geol. Survey Bull. 117 [Univ. of Kans. Pub.], 100 p., 1956.

Geography and geology are described in general, and the occurrence, movement, utilization, and chemical character of the ground water are described in some detail.

Walton, W. W. See Penrod, E. B.

Walton, William C.

Ground-water hydraulics as an aid to geologic interpretation: Ohio Jour. Sci., v. 55 , no. 1 , p. $13-20,1955$.

From pumping tests of wells, the water-bearing properties of a rock unit can be evaluated.

$\mathrm{W}_{\mathrm{ARD}}, \mathrm{W} . \mathrm{W}$.

Planned watershed management improves small city supply: Water Works Eng., v. 108 , no. 1 , p. $36-38,1955$.

The reforestation and scientific management of abandoned field on a Pennsylvania watershed are described.

\section{WARDLE, J. M.}

A major power plan for Yukon River waters in the Canadian Northwest: Eng. Jour. v. 40, no. 11, p. 1638-1646, 1957.

The plan is described, and political and physical problems are discussed. 
Wargo, Joseph G.

Drainage patterns in the Alambre Valley, Arizona: Ohio Jour. Sci., v. 55, p. 263266, 1955.

Stream patterns were influenced by the arrangement of platy elements present in some granitic rocks.

WARING, F. H.

Public water supplies and control of water pollution in Ohio: Ohio State Univ. Eng. Expt. Sta. Circ., no. 57, 36 p., 1955.

A historical and statistical summary is given.

Warnick, Calvin C. See also Robinson, A. R., Jr., 2.

Rime ice and snow capping on high altitude precipitation gages: Western Snow Conf. Proc., p. 24-34, Apr. 1957.

A résumé of research in Idaho is presented. Heated and unheated gages were used.

WARNICK, F. M.

(and Greenhalgh, William H.). Ground water and drainage problems of the Weber Basin Project, Utah: Am. Soc. Civil Engineers Proc., v. 81, Separate 619, 7 p., 1955. Control of leakage from confined ground-water basins and disposal of seepage from irrigation are necessary. The problems and the investigations are described.

Washicher, JACk N. See Stockwell, H. J., 1, 2, 3, 4, 5, 6.

Washington Department of Conservation and Development.

Monthly and yearly summaries of hydrographic data in the State of Washington, to Sept. 1953: Wash. Dept. Conserv. and Devel. Water Supply Bull., no. 6, 836 p., 1955.

The report includes a description of each gaging station, a table of monthly and yearly mean discharge, a table of minimum daily mean discharge which occurred each month and year, and a water-year summary table which includes annual momentary maximums.

Water for Texas Conference.

Water for Texas: Texas A. and M. Coll., Proc. Ann. Conf., 43 p., 1955.

Water Works Engineering.

1. What State legislatures are doing about water problems: Water Works Eng., v. 108 , no. 6 , p. $527-528,1955$.

Proposals and actions are summarized.

2. Ohio's underground water laws; common law vs. riparian rights: Water Works Eng., v. 111, no. 2, 1958.

Ohio is a riparian rights jurisdiction and applies the reasonable use doctrine.

3. New England area has 50-year water supply: Water Works Eng., v. 111, no. 9, p. 842-845, 1958.

The report gives excerpts from a voluminous report by the Director of the Bureau of the Budget to the Congress of the United States.

Waterways Experiment Station.

Velocity forces on submerged rocks: U.S. Army Corps Engineers, Waterways Expt. Sta. Misc. Paper, no. 2-265, 11 p., 1958.

Various formulas pertaining to bedload movement, rock-filled dams, breakwaters, and drag coefficients are studied.

Watkıns, F. A., JR. See Griffin, W. C.

WATSON, K. S.

Need for water management program in industry: Am. Water Works Assoc. Jour., v. 47 , no. 10 , p. $973-981,1955$. 
Water resources must be preserved. Methods of conserving and reusing water in industry are suggested by examples.

Weatherford, Richard L. See French, R. R.

Weaver, Frank L.

Outlook for hydroelectric development: Atomic Energy in Industry, Natl. Indus. Conf. Board, Inc., 5th Ann. Conf., 1957, p. 8-10.

A discussion is given of the prospects for future hydroelectric development in the United States and its probable cost.

Weers, L. O. See Pillsbury, A. F.

WEEKS, L. V.

(and Stolzy, L. H.). The use of portable neutron equipment to measure the quantity of water in large soil columns: Soil Sci. Soc. America Proc., v. 22, no. 3, p. 201-203, 1958.

The total water content in 4 soil columns was estimated periodically from readings taken with portable neutron equipment. Results were comparable with those obtained by other methods.

Weickmann, Helmut.

(and Smith, Waldo). Artificial stimulation of rain: New York, Pergamon Press, 427 p., 1957.

Proceedings of the first conference on the physics of cloud and precipitation particles at Woods Hole Oceanographic Institution, 1955 are given. The report contains 52 papers under four headings: Aerosals, condensation and coagulation, melting and freezing, and crystal growth and nucleation.

WEINBERger, M. L.

(and Ford, Erwin C.). Protecting watersheds-ways and whys, in U.S. Department of Agriculture, Land: Yearbook of Agriculture 1958, p. 356-363.

A big program to improve and develop watersheds has been started because of the realization that watershed protection results in usable water and productive land rather than floods, erosion, and sediment.

Weiss, Leonard L. See also Hershfield, D. M.

1. A nomogram based on the theory of extreme values for determining values for various return periods: Monthly Weather Rev., v. 83, no. 3, p. 69-71, 1955.

A convenient nomogram for quickly performing a Gumbel analysis on meteorologic or hydrologic data when the mean and standard deviation of the annual maximums for a given period of record are known. Basic equations and constants for the extreme-value distribution are included.

2. A nomogram for log-normal frequency analysis: Am. Geophys. Union Trans., v. 38, p. 33-37, 1957.

A nomogram is presented for determining log-normal return-period amounts directly from the mean and standard deviation of the annual-maximum series values. The log-normal return-period amounts are compared with those from a Gumbel analysis. (Discussion by Ven Te Chow, and author's closure, v. 38, p. 962-963, 1957.)

3. (and Wilson, Walter T.). Snow-melt degree-day ratios determined from snowlab data: Am. Geophys. Union Trans., v. 39, p. 681-688, 1958.

Degree days above $32^{\circ}$ was found to be more closely related to snowmelt than other cumulative temperature indexes. The relation changed according to the amount of forest cover. 
Weitzman, Sidney. See also Dunford, E. G., 1.

1. (and Trimble, G. R., Jr.). Integrating timber and watershed management in mountain areas: Jour. Soil and Water Conserv., v. 10, no. 2, p. 70-75, 1955.

Methods of logging are recommended that will greatly reduce damage to water quality.

2. (and Reinhart, Kenneth G.). Water yields from small forested watersheds: Jour. Soil and Water Conserv., v. 12, no. 2, p. 56-59, 1957.

The rainfall-streamflow pattern in a part of West Virginia is described.

WELD, B. A.

(and Asselstine, E. S., and Johnson, Arthur). Reports and maps of the Geological

Survey released only in the open files, 1957: U.S. Geol. Survey Circ. 403, 10 p., 1958.

Wells, Joseph V. B. See also Langbein, W. B., 2.

1. The program of surface water investigations in the West: Western Snow Conf. Proc., p. 16-19, Apr. 1955.

The program includes gaging-station operation, compilation of data, release of records currently, evaluation reports, hydrologic analyses, and equipment development.

2. Surface water resources: Am. Soc. Civil Engineers Trans., v. 123, p. 1206-1213, 1958.

The average annual runoff of a stream during a period of years tends to conform to a characteristic geographic pattern, whereas year-to-year runoff varies widely. Annual runoff from 1953-56 is analyzed briefly. Rapid expansion of irrigation in Eastern United States is described. The need for hydrologic analyses and legislation to meet problems is emphasized.

WeLSCH, E. Fred.

Conservation of ground water: Water and Sewage Works, v. 103, no. 10, p. 468$473,1956$.

The geology and hydrology of Long Island and methods of recharging the groundwater aquifer to prevent salt-water intrusion are described.

Welsch, W. Fred.

Ground water pollution from industrial wastes: Sewage and Indus. Wastes, v. 27, no. 9 , p. $1065-1069,1955$.

The discharge of plating wastes is creating a hazardous situation in sections of Long Island. (Discussion by Maxim Lieber.)

Wendt, Immo. See von Buttlar, H., 1.

WENGERT, Norman.

Natural resources and the political struggle: Garden City, N. Y., Doubleday and Co., 68 p., 1955.

An analysis is presented of the way in which political processes operate with respect to natural-resources questions. Several examples are drawn from the waterresource field.

WENT, F. W.

Fog, mist, dew, and other sources of water, in U.S. Department of Agriculture,

Water: Yearbook of Agriculture 1955, p. 103-109.

The importance of those sources to plants in certain areas is described.

Wentworth, Chester K.

(and Mason, Arnold C., and Davis, Dan A.). Salt-water encroachment as induced 
by sea-level excavation on Angaur Island: Econ. Geology, v. 50, no. 7, p. 669$680,1955$.

Angaur Island provides a model of the operations of a Ghyben-Herzberg freshwater lens on an oceanic island. When inland mining excavations were extended below sea level, contamination of fresh-water supplies by salt water resulted from tidal pulsations through fissured rock. Continuing observations were made of water levels; amplitude and lag of tidal fluctuations; and mineral content, $\mathrm{pH}$, and temperature of the lens.

WERNER, P. WIrh.

Some problems in non-artesian ground-water flow: Am. Geophys. Union Trans., v. 38, p. 511-518, 1957.

Two cases are treated, the flow between two reservoirs and the flow between a water divide and a reservoir. Water-table conditions are assumed and replenishment from the ground surface is an additional factor. (Discussion by M. Maasland, and author's closure, v. 39, p. 738-741, 1958.)

West, A. J. See Anderson, H. W., 6, 7.

West, Eugene M.

(and Hughes, Ronald D.). The development and use of hydraulic models in a study of culvert performance: Ky. Eng. Expt. Sta. Bull. 41, 56 p., 1956.

West, S. W. See Nace, R. L., 1.

Westgarth, Warren C. See Northcraft, M.

Wetzel, Barton F. See Decker, J. P.

WEXLER, $\mathrm{H}$.

Modifying weather on a large scale: Science, v. 128, no. 3331, p. 1059-1063, 1958.

Current proposals are either impractical or likely to produce cures that are worse than the ailment.

Whelan, Donald E.

1. (and Tripp, Norman R.). A method for determining surface runoff from watersheds: Jour. Soil and Water Conserv., v. 10, no. 3, p. 129-131, 1955.

The method is a mathematical computation in which the storm rainfall is timed as it passes through the soil. Runoff and precipitation records and soil surveys are needed to establish the relations.

2. Effects of land use on streamflow: Ala. Acad. Sci. Jour., v. 29, no. 4, p. 55-60, 1957.

Theories are presented of infiltration, runoff, ground-water flow, and evapotranspiration in relation to land use and vegetation.

Whisler, Benjamin A.

(and Smith, Charles J.). The estimation of the frequency of rare floods: Am. Soc.

Civil Engineers Proc., v. 83, no. HY 2, Paper 1200, 10 p., 1957.

A method of estimating the frequency of annual peak flows from recorded monthly peak flows is suggested. (Discussions by Gordon R. Williams, v. 83, no. HY 3, Paper 1283, p. 11-12, 1957; Leo R. Beard, Manuel A. Benson, v. 83, no. HY 5, Paper 1417, p. 21-26, 1957, and authors' elosure, v. 84, no. HY 2, Paper 1616, p. 7,1958 .)

White, D. E. See Thomas, H. E., 3.

White, Donald E.

1. Thermal waters of volcanic origin: Geol. Soc. America Bull., v. 68, p. 1637-1658, 1957. 
Based on a study of selected hot springs, it is concluded that the contribution of water of direct volcanic origin is probably no more than 5 percent in typical sodiumchloride springs.

2. Magmatic, connate, and metamorphic waters: Geol. Soc. America Bull., v. 68, p. 1659-1682, 1957.

This paper reviews the characteristics of the different kinds of "deep" water. Tentative criteria are proposed to distinguish waters of different origins.

White, Gilbert F.

1. The future of arid lands: Am. Assoc. Adv. Sci., 464 p., 1956.

The book contains papers and recommendations of 69 scientists from 17 countries. The problem of water resources is given much attention.

2. (and Calef, Wesley C., Hudson, James W., Mayer, Harold M., Scheaffer, John R., and Volk, Donald J.). Changes in urban occupance of the flood plains of the United States: Chicago Univ., Dept. Geography Research Paper, no. 57, 235 p., 1958.

An exploratory study of the urban flood problem is made, and an assessment of the change in 17 flood-plain areas from 1936 to 1957 is given. Estimates of flood losses are given, and protection and abatement programs described. Maps of flood-plain occupance are included.

White, N. D. See Johnson, P. W.

Widman, L. E. See Roberts, C. M.

WIEGEL, R. L.

(and Snyder, C. M., and Williams, J. B.). Water gravity waves generated by a moving low pressure area: Calif. Univ. Wave Research Lab., ser. 99, no. 2, 13 p., 1957.

The coupled water gravity waves generated by a moving low pressure area, such as a hurricane, have been studied in a towing tank. The results agreed with the comparable effects of Hurricane Carol.

Wikramanayake, V. E. A. See Ayers, H. D., 2.

Wiksten, Ake.

Review of Tree-ring Analyses of Danish Forest Trees, by Erik Holmsgaard: Forest Sci., v. 2, p. 105-106, 1956.

The original doctorate dissertation is written in Danish. Of interest to hydrologists is the significant correlation of precipitation and temperature with the width of tree rings for the period $1900-1949$.

Wilcox, J. C.

(and Holland, W. D., and McDougald, J. M.). Relation of elevation of a mountain stream to reaction and salt content of water and soil: Canadian Jour. Soil Sci., v. 37 , no. 1 , p. 11-20, 1957.

Water samples in Okanagan basin had a higher $\mathrm{pH}$ and salt content at low elevation than at high elevation.

Wilcox, L. V. See Wadleigh, C. H.

Wiley, A. J. See Lueck, B. F.; Scott, R. H.

Wilke, Harvey R. See Howe, R. H. L., 1.

Wilke, Richard W. See Hartman, M. A., 1, 2.

Wilkinson, JaCkson H.

Study of rainfall station locations in South Chickamauga Creek watershed: Am. 
Geophys. Union Trans., v. 36, p. 1021-1028, 1955.

The number and location of rainfall stations needed for streamflow prediction purposes on a 428 -square-mile watershed is determined.

Willets, David B.

(and McCullough, Charles A.). Salt balance in ground water reservoir operation:

Am. Soc. Civil Engineers Proc., v. 83, no. IR 2, Paper 1359, 10 p., 1957.

Operation of ground-water reservoirs for cyclic water storage requires maintenance of suitable mineral quality. A method of computing the quality is described. (Discussion by Robert $O$. Thomas, v. 84, no. IR 2, Paper 1615, p. 9-12, 1958, and authors' closure, v. 85, no. IR 1, Paper 1986, p. 65, 1959.)

Williams, D. A.

1. Soil and water conservation in action: Soil Conserv., v. 20, no. 11, p. 249-251, 1955.

The program and objectives of the Soil Conservation Service are given.

2. Soil and water for the future: Soil Conserv., v. 21, no. 5, p. 115-119, 1955.

The report is based on an address at the 1955 annual meeting of the National Reclamation Association.

3. Water for everyone: Plant Food Rev., v. 3, no. 4, Winter 1957.

If we are to continue to have water for everyone, a program that will control the water from the time it falls on the land until it has passed through all feasible uses is needed.

4. It's the rain you keep that counts: Soil Conserv., v. 23, no. 3, p. 60-64, 1957. Moisture penetration under different cover types and conservation practices is given.

5. Our fresh water supply. Nation's newest critical resource: United Fresh Fruit and Vegetable Assoc. 1958 Yearbook, p. 160-163, 1958.

The Nation's water supply shapes the pattern of population growth and industrial development. Solutions to water problems depend on control and management of the local water resource.

Williams, G. P. See also Gold, L. W.

1. A field determination of free water content in wet snow: Western Snow Conf. Proc., p. 16-20, Apr. 1956.

A good relation was found between free water content and compacted density.

2. Evaporation from snow covers in eastern Canada: Eastern Snow Conf. Proc., p. 19-30, 1958.

Field measurements were compared with calculated values.

Williams, Gordon R. See Adams, H. W., 2; Childs, E. F.; Langbein, W. B., 6; Whisler, B. A.

Williams, J. B. See Wiegel, R. L.

Williams, Jerome.

The sediment probe: Johns Hopkins Univ., Chesapeake Bay Inst. Tech. Rept. 10, 5 p., 1956.

The probe consists of a 2-prong fork, one side containing a bank of photocells and the other containing a light source to illuminate the cells.

Williams, Leon G.

1. (and Knox, Homer, Kaser, Paul, and Patterson, J. R.). Eastern water shortage and drought problems, conditions in Ohio: Am. Water Works Assoc. Jour., v. 47 , no. 3 , p. 203-212, 1955. 
This article reports the effect of the drought, immediate counter-measures taken, and the long-range solutions advocated.

2. Water supply from upland storage: Am. Water Works Assoc. Jour., v. 49, no. 3, p. 277-282, 1957.

Advantages, disadvantages, and a typical installation are described.

Williams, Melvin R.

Water resources and water developments in Alabama: Am. Soc. Civil Engineers Proc., v. 83, no. PO 6, Paper 1459, 4 p., 1957.

Water resources are evaluated, and the increasing demands on the supply are described.

WillinghaM, J. W.

The indirect determination of forest stand variables from vertical aerial photographs: Photogramm. Eng., v. 23, no. 5, p. 892-893, 1957.

Age or growth rate of trees may be determined indirectly from variables that can be measured, such as tree height or crown cover.

Willson, R. C. See Ningard, L. G.

Wilm, H. G. See also Goodell, B. C., 1; Penman, H. L.

1. The training of men in forest hydrology and watershed management: Jour. Forestry, v. 55, p. 268-272, Apr. 1957.

A committee report with recommendations for on-the-job and college training is presented.

2. Forest watershed problems in New York State: Soc. Am. Foresters Proc., p. 28-29, 1957.

Carefully regulated manipulation of vegetation may provide greater benefits to watershed values than does complete forest protection.

Wilson, Milton T. See also Love, L. D., 2.

Variations in streamflow from different hydrologic zones: Western Snow Conf. Proc., p. 53-57, Apr. 1957.

The double-mass diagram and streamflow correlations are used to show variation between zones. (Discussion by F. B. Blanchard.)

Wilson, Walter T. See also Burgy, R. H., 1; Corn, H. M.; Hershfield, D. M.; Linsley, R. K., 2; Potter, W. D., 2; Weiss, L. L., 3.

1. Recent trends in improvement of winter precipitation measurements: Eastern Snow Conf. Proc., v. 3, p. 4-6, 1955.

New methods of measuring water content of snow are described and evaluated.

2. (and Hershfield, D. M.). Frequency analysis of rainfall intensity data: Agr. Eng., v. 39, no. 6, p. 344-347, 1958.

This paper describes the seasonal variation and other characteristics of the rainfall intensity regime and the Weather Bureau's work along these lines.

WingFieLD, D. W.

Trees versus water and grass: Jour. Range Management, v. 8, no. 4, p. 149-150, July 1955.

Optimum yields of water, grass, and trees can be obtained from rangeland by removing scrub trees and brush.

Winslow, Allen G. See also Petitt, B. M., Jr.

1. (and Kister, L. R.). Saline-water resources of Texas: U.S. Geol. Survey Water-Supply Paper 1365, 105 p., 1956. 
This report outlines the occurrence, quantity, and quality of available saline waters. This information will help in determining where particular saline-water conversion processes may be feasible.

2. (and Doyel, William W., and Wood, Leonard A.). Salt water and its relation to fresh ground water in Harris County, Texas: U.S. Geol. Survey WaterSupply Paper 1360-F, p. 375-407, 1957.

Large withdrawals of fresh ground water in the Houston area have reversed the direction of the hydraulic gradient, and salt water has begun to move slowly toward the center of pumping. Continuous observation in existing wells and in wells that should be drilled is suggested.

Wischmeier, Walter H. See also Smith, D. D., 2.

1. Punched cards record runoff and soil-loss data: Agr. Eng., v. 36, no. 10, p. 664666, 1955.

A program of U.S. Department of Agriculture, Agricultural Research Service for editing, coding, and recording runoff and soil-loss data collected during the past quarter century is described. Use of data in punched cards is described.

2. (and Smith, D. D., and Uhland, R. E.). Evaluation of factors in the soil-loss equation: Agr. Eng., v. 39, no. 8, p. 458-462, 1958.

Recent developments add to the information available to serve as a basis for factors comprising the soil-loss estimating equation.

3. (and Smith, Dwight D.). Rainfall energy and its relationship to soil loss: Am. Geophys. Union Trans., v. 39, p. 285-291, 1958.

A method is presented for computation of kinetic energy of a rainstorm from information on a recording-raingage chart. Rainfall energy is described by an equation as a function of rainfall intensity. By regression analyses, soil loss is related to energy and intensity.

Wise, William S.

Pollution control in New England: Sewage and Indus. Wastes, v. 30, no. 1, p. 86-92, 1958.

Experiences in New England and the influence of the New England Interstate Water Pollution Control Commission are discussed.

Wisemen, John W.

Potential conflicts between supplemental irrigation and pollution abatement programs: Sewage and Indus. Wastes, v. 27, no. 11, p. 1284-1287, 1955.

In Eastern United States irrigation demands come at times of low streamflow and complicate the pollution abatement problem.

Wisniewski, T. F. See Lueck, B. F.; Scott, R. H.

Witherspoon, D. F.

1. (and Hore, F. R.). Design of a proportional weir for use in a flowmeter: Agr. Eng., v. 38 , no. 12 , p. $867,1957$.

The weir is described.

2. (and Ayers, H. D.). Measuring watershed runoff in Ontario: Agr. Eng., v. 39, no. 7, p. 403-405, 1958.

The report describes 20 -acre experimental plots on which precipitation, solar radiation during the snowmelt period, and runoff were measured.

Witmer, T. Richard.

Documents on the use and control of the waters of interstate and international streams: U.S. Dept. Interior, 760 p., 1956.

The report contains all the interstate compacts presently in force among the States 
which apportion or govern the use or control of the waters of interstate streams. Treaties between the United States and Canada or Mexico also are included.

Witzigman, Frederick S.

1. (and Shepherdson, Isaac). 1954 aggradation surveys in Garrison reservoir, Missouri River, North Dakota: U.S. Army Corps Engineers, Missouri River Div., Sediment Memo., no. 2, 4 p., Jan. 1955.

2. Observations of rate of change in sediment concentration with respect to changing hydraulic conditions at head of a reservoir: U.S. Army Corps Engineers, Missouri River Div., Sediment Memo., no. 4, 5 p., Feb. 1955.

3. Degradation below Garrison Dam; observations in 1954: U.S. Army Corps Engineers, Missouri River Div., Sediment Memo., no. 3, 11 p., Apr. 1957.

The report covers the study made on 23 degradation ranges established for observing rate and magnitude of degradation of the river due to operation of the reservoir. Other observations made include: water surface profiles, a continuous record of normal readjustments of the riverbed at a given section, shift in stage-discharge relation curve at gaging stations, riverbed material grain size, and suspended sediment load and grain size.

WolcotT, H. N.

(and Skibitzke, H. E., and Halpenny, L. C.). Water resources of Bill Williams River valley near Alamo, Arizona: U.S. Geol. Survey Water-Supply Paper 1360-D, p. 291-319, 1956.

An investigation was made to determine the availability of water for a manganese mine. During a period of several months in almost every year the available supply is less than the estimated requirements. Three solutions to the problem are suggested.

Wolfe, C. G. See Court, A., 2; Hannaford, J. F., 2.

Wolman, Abel.

1. Basic principles of a national water resources policy; Am. Water Works Assoc. Jour., v. 49, no. 7, p. 825-830, 1957.

Report of a committee of the AWWA (American Water Works Association). A statement of the AWWA policy is included.

2. A fresh approach to water law: Am. Water Works Assoc. Jour., v. 50, no. 10, p. 1279-1284, 1958.

Problens of water use are not technical; they are human.

Wolman, M. Gordon.

1. (and Leopold, Luna B.). River flood plains; some observations on their formation: U.S. Geol. Survey Prof. Paper 282-C, p. 87-109, 1957.

The flood plain usually consists of channel and overbank deposits. Detailed studies of flood plains and observations indicate that overbank deposition contributes only a minor part of the material constituting the flood plain.

2. (and Eiler, Jack P.). Reconnaissance study of erosion and deposition produced by the flood of August 1955 in Connecticut: Am. Geophys. Union Trans., v. 39, p. 1-14, 1958.

A large area in the valley bottons in Connecticut was inundated by the flood of August 1955. Relative to the total area flooded that part permanently modified by the flow was small. Channel and flood plain modifications at specific sites are described.

Wood, Leonard A. See also Winslow, A. G., 2.

1. Pumpage of ground water and changes in water levels in Galveston County, 
Texas, 1952-57: Texas Board Water Engineers Bull. 5808, 23 p., 1958. 2. Pumpage of ground water and fluctuations in water levels in the Houston district and the Baytown-La Porte area, Texas, 1955-57: Texas Board Water Engineers Bull. 5805, 40 p., 1958.

Woodbridge, David D.

A storm analysis of the Tillamook Burn cloud-seeding operation: Am. Meteorol. Soc. Bull., v. 36, no. 1, p. 22-26, 1955.

Previously-typed storms were compared with similar storm types that passed through the area during the seeding period of the summer of 1951. Only one occasion occurred where cloud-seeding might possibly have caused rain.

WoodbuRn, RUSSELx.

1. Sediment production in small watersheds: Agr. Eng., v. 36, no. 7, p. 467-470, 1955.

This paper discusses sediment-yield studies of 1949-54 in Yazoo basin, Mississippi, on small gullied areas, partly gullied areas as much as 500 acres, and 1 watershed of 12 square miles.

2. (and Kozachyn, John). A study of relative erodibility of a group of Mississippi gully soils: Am. Geophys. Union Trans., v. 37, p. 749-753, 1956.

Erodibility was measured in the laboratory and in the field. Although different soils show widely different erosion rates, no acceptable laboratory method of measuring relative erodibility was found.

3. (and Kozachyn, John). Sediment problem studied in Yazoo watershed: Miss. Farm Research, v. 19, no. 5, p. 1, 8, 1956.

These studies were planned to evaluate the effect of mulch, trees, and kudzu separately or in appropriate combination on sediment production by gullied areas.

Woodrufr, C. M. See Veihmeyer, F. J., 1.

WoodrufF, JAMES F.

(and Parizek, Eldon J.). Influence of underlying rock structures on stream courses and valley profiles in the Georgia Piedmont: Annals Assoc. Am. Geographers, v. 46 , no. 1, p. 129-139, 1956.

Lithology and structure strongly influence valley shapes and stream courses.

Woodruff, N. P. See Hanks, R. J.

Woodside, Wirriam. See also Lachenbruch, A. H.

(and Kuzmak, J. M.). Effect of temperature distribution on moisture flow in porous materials: Am. Geophys. Union Trans., v. 39, p. 676-680, 1958.

Based on model studies, the average temperature gradient in the pore spaces was found to be six times the overall applied gradient. (Discussion by D. A. de Vries and J. R. Philip, Jour. Geophys. Research, v. 64, p. 386-388, 1959; and authors' reply, Jour. Geophys. Research, v. 64, p. 2035-2036, 1959.)

Woodward, Douglas R. See also Thomas, R. O., 2.

Availability of water in the United States with special reference to industrial needs by 1980: U.S. Indus. Coll. Armed Forces, 74 p., 1957.

A general evaluation of the availability of raw water, by regions, is given.

Work, R. A. See also Codd, A. R.

1. Measuring snow to forecast water supplies, in U.S. Department of Agriculture, Water: Yearbook of Agriculture 1955, p. 95-102.

Methods of measuring the snowpack and forecasting seasonal runoff are described. Examples of specific benefits are cited. 
2. Western States snow surveys and seasonal water-supply forecasts: Eastern Snow Conf. Proc., v. 3, p. 93-97, 1955.

A general description is given.

3. Measurement and management of watershed snow packs: Soc. Am. Foresters Proc., p. 195-198, 1955.

Measurement of the snow resource is described, and research in management of watershed snow packs is shown to be necessary.

4. (and Beaumont, R. T.). Basic data characteristics in relation to runoff forecast accuracy: Western Snow Conf. Proc., p. 45-53, Apr. 1958.

The weighted-precipitation method and the snow-survey method of forecasting runoff are evaluated. The latter method is generally more accurate.

Worley, David P.

(and Meyer, H. Arthur). Measurements of crown diameter and crown cover and their accuracy for 1:13,000 photographs: Photogramm. Eng., v. 21, no. 3, p. $372-375,1955$.

More accurate results were obtained with the shadow wedge than with the dot comparison.

Wright, Bern. See Douglass, J. B.

Wright, KenNeth R. See also Zoller, J. H.

Model approach to a ground water problem: Am. Soc. Civil Engineers Proc., v. 84, no. IR 4, Paper 1862, 9 p., 1958.

Models can be used to determine directions of flow, velocities, location of hydraulic divides, and to forecast future conditions.

Wyckoff, Pete.

Snow surveys from the snow surveyor's side: Western Snow Conf. Proc., p. 57-59, Apr. 1957.

Problems of collecting data are discussed.

Wyoming Natural Resource Board.

Wyoming's water resources: Wyo. Nat. Resource Board, 76 p., 1956.

The report describes the history of water-resources development in Wyoming, the interstate compacts, existing irrigation projects, and potential projects.

Wyrick, Granville G.

(and Leutze, Willard P.). Interim report on ground-water resources of the northeastern part of Volusia County, Florida: Fla. Geol. Survey Inf. Circ., no. 8, 75 p., 1956.

The report describes geography, geology, ground water occurrence, salt-water contamination, and quantitative studies.

YALE, RoBert A.

Use of radial collector well in Skagit County, Wash.: Am. Water Works Assoc. Jour., v. 50, no. 1, p. 125-128, 1958.

Water infiltrated from the river is of better quality than the ground water. Construction and operation of the well are described.

Yamaoka, Yoshito.

1. Experimental studies on the relation between transpiration rate and meteorological elements: Am. Geophys. Union Trans., v. 39, p. 249-265, 1958.

Transpiration rate was measured using a wind tunnel which can maintain any meteorological condition. The potometer method was examined and found satisfactory. 
The relation of transpiration rate to radiation intensity and wind velocity was defined. Systematic relations were found between leaf temperature, transpiration rate, and meteorological elements.

2. The total transpiration from a forest: Am. Geophys. Union Trans., v. 39, p. 266-272, 1958.

Total leaf weight was found to be proportional to square of breast-height diameter. A relation between transpiration rate and meteorological elements was defined for a single species and used to estimate the total transpiration from a 1.1-acre forest.

Yatsu, Eisu.

On the longitudinal profile of a graded river: Am. Geophys. Union Trans., v. 36, p. 655-663, 1955.

Study of the longitudinal profiles and grain-size distribution of fluviatile deposits of nine Japanese rivers indicates that the typical graded profile is not a single exponential curve.

Yevdjevich, V. M. See Langbein, W. B., 4.

Yin, Chia-Shun. See Zee, C. H.

Yost, C. B., JR. See Armstrong, C. A.

YosT, I. D.

Floods of June 1954 in Iowa: U.S. Geol. Survey Water-Supply Paper 1370-A, p. 1-106, 1958.

Streams in north-central and northwest Iowa rose to record heights in many places. The floods are described, and detailed records of stages and discharges are given.

Young, Lewis A.

The USPHS stream pollution abatement program: Am. Soc. Civil Engineers Proc., v. 83, no. SA 4, Paper 1338, 9 p., 1957.

The new Federal Water Pollution Control Law and the importance of protecting our water resources are considered.

Young, Loxd L.

Developed and potential water power in the United States and other countries of the world, December 1954: U.S. Geol. Survey Circ. 367, 14 p., 1955.

Tabulations and a discussion are given.

YoungBerg, C. T. See Dyrness, C. T.

Youngquist, C. V. See Callahan, C. C.

Youngs, E. G.

1. Moisture profiles during vertical infiltration: Soil Sci., v. 84 , no. 4 , p. 283-290, 1957.

Theoretical moisture profiles are compared with experimental profiles for two cases. Good agreement is found.

2. Redistribution of moisture in porous materials after infiltration. Part 1: Soil Sci., v. 86, no. 3, p. 117-125, 1958.

A laboratory study is presented of horizontal redistribution following cessation of infiltration.

3. Redistribution of moisture in porous materials after infiltration. Part 2: Soil Sci., v. 86 , no. 4 , p. 202-207, 1958.

Moisture profiles during the redistribution after vertical infiltration were obtained by experiment. 
Zadrozny, Mitchell G.

Water utilization in the Middle Mississippi Valley: Chicago Univ. Dept. Geography Research Paper, no. 45, 119 p., 1956.

The report describes the area, the regional objectives in regard to water utilization, present uses of water, disbenefits of water, and major problems.

ZaHNER, RoBERT.

1. Soil water depletion by pine and hardwood stands during a dry season: Forest Sci., v. 1, no. 4, p. 258-264, 1955.

Measurements of soil moisture on pine and on hardwood plots showed little difference in rate of loss between the two stands for corresponding depths. In both stands, layers below 3 feet lost water at about half the rate of the upper layers.

2. Evaluating summer water deficiencies: U.S. Forest Service, Southern Forest Expt. Sta. Occasional Paper 150, 18 p., 1956.

Thornthwaite's concept of potential evapotranspiration, combined with an understanding of water needs and supplies, can be used to estimate water deficiencies suffered by trees. This paper presents background material and data for evaluations on upland pine-hardwood forests of the Midsouth.

3. Hardwood understory depletes water in pine stands: Forest Sci., v. 4, no. 3, p. 178-184, 1958.

Soil water depletion by pine stands with and without hardwood understories was measured through four summers in Arkansas. Midsummer water-loss rates were about 25 percent greater in plots with understory than in those without.

\section{Zee, Chong-Hung.}

(and Peterson, Dean F., Jr., and Bock, Robert O.). Flow into a well by electric and membrane analogy: Am. Soc. Civil Engineers Trans., v. 122, p. 1088-1105, 1957.

A study of radially symmetrical, unconfined flow to a well is given. The problem is approached by combining the electric analogy for hydraulic flow with the membrane analogy for a free surface. Experimental results are used to develop empirical relationships between the flow and geometric variables. (Discussion by Robert E. Glover, Vaughn E. Hansen, James N. Luthin, and Chia-Shun Yih.)

Zeizer, Arthur J. See Bergstrom, R. E., 3.

Zether, Bernard D.

Hurricane effect on sea level at Charleston: Am. Soc. Civil Engineers Proc., v. 83, no. HY 4, Paper 1330, 19 p., 1957.

Tropical cyclones from 1922 to 1955 have been classified according to the orientation of their tracks with respect to Charleston Harbor. The displacement of sea level depends on this orientation.

Zimmerman, Aaron L.

Reconstruction of the snow-melt hydrograph in the Payette River Basin: Western Snow Conf. Proc., p. 29-34, Apr. 1955.

A method of predicting flow on the basis of temperature, snowline position, rainfall, and infiltration is developed and tested.

\section{Zimmerman, Everett A.}

Preliminary report on the geology and ground-water resources of parts of Musselshell and Golden Valley Counties, Montana: Mont. Bur. Mines and Geology Inf. Circ., no. 15, 28 p., 1956.

ZINGG, A. W. See Brakensiek, D. L., 1. 


\section{ZOLLER, J. HAROLD.}

(and Lenz, Arno T.). Snowmelt runoff: Am. Soc. Civil Engineers Proc., v. 84, no. HY 6, Paper 1834, 31 p., 1958.

Factors which cause the melting of snow are evaluated for a river basin in Wisconsin. (Discussions by K. R. Wright, v. 85, no. HY 2, Paper 1950, p. 103-111, 1959; H. C. Riggs, v. 85, no. HY 5, Paper 2045, p. 187-188, 1959; Francis T. Schaefer, v. 85 , no. HY 6, Paper 2076, p. 69-72, 1959; and authors' closure, v. 85, no. HY 11, Paper 2269, p. 117-118, 1959.)

Zwerman, Paul J. See Bouwer, H. 



\section{INDEX}

Alabama.

ground water: Baker, J.; Cagle, J. W., Jr.; Ivey, J. B.; LaMoreaux, P. E., 1; Malmberg, G. T.; Miller, J. D., Jr., 1, 2; Powell, W.J., 1; Sanford, T. H., Jr.; Scott, J. C.; Sutcliffe, H., Jr.

hydrology: Peirce, L. B.

maximum station precipitation: U.S. Weather Bureau, 7.

springs: Harris, H. B.

water resources: Robinson, W. H.; Williams, M. $\mathbf{R}$.

Alaska.

climate: Dale, R. F., 1; Mitchell, J. M., Jr.

glaciers: Case, J. B.; Muntz, A. P.; Sharp, R. P., 2.

permafrost: Hopkins, D. M.

streamflow: U.S. Geological Survey, 15, 25, 26. water supply: Black, R. F.

watershed-management research: Anderson, H. E.

Aquifer tests: Hantush, M. S., 4; Remson, I., 4.

Arizona.

climate: Smith, H. V.

drought: Cushman, R. L.

erosion: Berry, W. H.

ground water: Armstrong, C. A.; Coates, D. R.,

1; Harshbarger, J. W.; Johnson, P. W.;

Metzger, D. G.; Schwalen, H. C.

water quality: Coates, D. R., 1; Marx, G. W. water resources: Wolcott, H. N.

watershed program: Arizona Water Resources

Committee, 1, 2; Rowe, P. B., 2; Gaffney,

P. C., 49.

weather modification: Buell, C. E.

Arkansas.

ground water: Baker, R. C.; Counts, H. B., 1, 2; Onellion, F. E., 1, 2.

soil and water losses: Batholomew, R. P.

surface-water resources: Arkansas Water Study Commission.

water quality: Dover, T. B.; Geurin, J. W.; Krause, K. S.

Arkansas River basin.

description and development: Arkansas-WhiteRed Basins In ter-Agency Committee.

sedimentation: U.S. Corps of Engineers, 14.

Artesian water: Helwick, C. H.

Australia.

floods: Engineering News-Record, 1.

Brackish water.

relation to geology: LeGrand, H. E., 1.

British Columbia.

runoff characteristics: Raudsepp, W.

California.

economics of water-resource development: Ciriacy-Wantrup, S. V.; Stanford Research Institute.
California-Continued.

evaporation: Blaney, H. F., 1, 3.

floods: California Disaster Office; California

Water Resources Board, 6; Cassidy, W. F.;

Rantz, S. E.

geological engineering: Trask, P. D.

ground water: Back, W.; Cardwell, G. T.;

Davis, G. H.; Mack, S.; Upson, J. E., 2. ground-water law: Chase, R. W.

ground-water situation: Todd, D. K., 5.

investigations: California Department of Water

Resources, 1, 3,6, 8, 9; California Division of

Water Resources, 3, 4, 8, 9, 10; California

Water Project Authority; California Water

Resources Board, 2, 3, 4; Snyder, J. H.; U.S.

Bureau of Reclamation, 21.

mountainous areas: California Division of

Water Resources, 1.

salinity barriers: California Department of

Water Resources, 7; California Division of

Water Resources, 6.

sea-water intrusion: Banks, H. O., 1; California

Department of Water Resources, 11.

sediment problems: Einstein, H. A., 3.

seepage conditions: California Division of

Water Resources, 2.

snow-management research: Anderson, H. W.,

waste-water reclamation: California Department of Water Resources, 12.

water conditions: California Division of Water Resources, 5.

water facts: California Department of Water Resources, 13.

water plan: California Department of Water Resources, 5; Griffith, C. A.; Holsinger, H.;

Morris, S. B., 1.

water quality: California Department of Water

Resources, 2, 4; California Division of Water

Resources, 7, 11.

water resources: Hofmann, W.; Matthai, H. F.,

3; Peterson, W. C.; Troxell, H. C.

water rights: Hutchins, W. A., 4.

water utilization: California Water Resources

Board, 1.

water-utilization planning: Shelton, M. J. watershed management: Hopkins, W., 1, 3. weather modification: California Division of

Water Resources, 12; California Water

Resources Board, 5.

well construction: California Department of

Water Resources, 10.

Canada. See also listings of individual provinces. ground temperatures: Crawford, C. B. ground water: Pollitt, $\mathrm{K}$. pollution: Berry, A. E., 1. 
Channels. See also Hydraulics, Sand channels. Dowsing: Roberts, K. L.; Roseberry, C. R.; alluvial: Blench, T.; Brooks, N. H.; Carey, W. C.; Chien, N., 2, 3; Kolb, C. R.; Lane, E. W., 2; Laursen, E. M., 2; Liu, H. K., 1; Terrell, P. W.

effect of beavers: Retzer, J. L.

problems of: U.S. Bureau of Reclamation, 1. stable: Bretting, A. E.

Climate.

Arizona: Smith, H. V.

Canada: Kendrew, W. G.

cold-wet conditions: Meigs, $P$.

general: Koeppe, C. E.

Matanuska Valley: Dale, R. F., 1.

trends: Berrill, N. J.; Von Eschen, G. F.

United States: Visher, S. S.

Climatology.

freezing: Thom, H. C. S., 2.

research: Craig, H., 2.

trends: Landsberg, H. E.

Cloud seeding. See Weather modification.

Colorado.

ground water: Babcock, H. M.; Bjorklund, L. J., 2; McLaughlin, T. G., 1; Powell, W. J., 2.

water quality: Babcock, H. M.; Bjorklund, L. J., 2.

water-resource planning: Crawford, I. C., 2. water resources: Crawford, I. C., 1. water-table fluctuations: Code, W. E.

Columbia River basin.

general: Holbrook, S.

international problems: American Society of International Law.

plan: Engineering News-Record, 17. water quality: Sylvester, R. $O$.

Connecticut.

dam safety: Curry, J. J.

flood frequency: Bigwood, B. L., 1, 2.

flood-plain definition: Pelletier, C. J.

water resources: Connecticut Water Resources Commission.

Conservation. See Soil and water conservation.

Consumptive use. See also Evapotranspiration.

Criddle, W. D., 1, 3, 4; Goodrich, R. D.; Hargreaves, G. H.; Houston, C. E.; Skinner, T. C.

Current meters: Middleton, F. H.

Cyclones: Hosler, C. L.; Klein, W. H.

Dams: Mermel, T. W.

Data processing: Dale, R. F., 2.

Delaware.

salt-water encroachment: Rasmussen, W. C., 5. water resources: Marine, I. W.; Rasmussen, W. C., $2,4$.

water rights: Ellis, H. H.

Delaware River basin.

ground-water resources: Barksdale, H. C., 1, 2. salinity: Cohen, B.

water balance: Carter, D. B., 3; van Hylckama, T. E. A., 2.

water problem: Schnader, W. A.

water quality: Durfor, C. N.

Deserts.

North America: Jaeger, E. C.

Sowder, A. M.

Drainage. See also Flow through porous media. and flood control: Herndon, L. W.

design: Keifer, C. J.

general: Sutton, J. G.

investigation techniques: Evans, N. A.; U.S.

Bureau of Reclamation, 4.

leveed areas: Adams, H. W., 2.

research: Bouwer, $\mathrm{H}$.

subsurface: Edwards, D. H.; Fukuda, H.; Isherwood, J. D.; Kirkham, D.

theory: Day, P. R., 2; Hollingsworth, B. J. tile systems: Pillsbury, A. F.

Drainage-basin characteristics. See also Topographic characteristics.

parameters: Chorley, R. J.

Droughts.

agricultural: Palmer, R. S.; van Bavel, C. H. M., 1, 4, 5, 6.

and reservoir design: Hudson, H. E., Jr.

effect of storage: Matzke, S.

meteorological aspects: Muilenburg, G. A.; Namias, J.

problems: Douglass, J. B.; Engineering NewsRecord, 9; Snow, B. C.; Wallace, D. S.; Williams, L. G., 1.

Duration curves: Mitchell, W. D.

Erosion.

by flood: Wolman, M. G., 2.

canal: U.S. Bureau of Reclamation, 9, 20.

channel: Coldwell, A. E.

control: Berry, W. H.; Bjorkbom, J. C.;

Dunford, E. G., 1; Francis, C. J.; Hays,

O. E., 2; Kraebel, C. J.; Krimgold, D. B.;

Roark, C. L.; Trimble, G. R., Jr., 3.

cultivated land: Blakely, B. D.

effect on landscape: Smith, G. D.

measurement: Gleason, C. H., 2.

processes: Barnett, A. P.; Gottschalk, L. C.,

1; Hadley, R. F.; Osborn, B.; Schumm,

S. A., 1, 3.

project studies: U.S. Bureau of Reclamation, $6,7$.

recognition: U.S. Soil Conservation Service, 1. relative: Woodburn, R., 2 .

research: Rowe, P. B., 3.

sheet and rill: Glymph, L. M., Jr.; Smith, D. D., 2.

slope retreat: Tanner, W. F.

Evaporation.

effect of salinity: Harbeck, G. E., Jr., 1.

estimation: Penman, H. L.

field estimation: Lowry, W. P.

from soil: Gardner, W. R., 2, 3; Hanks, R. J.; Lemon, E. R., 1; Musgrave, G. W., 2; Philip,

J. R., 2; Selleck, G. W.; Veihmeyer, F. J., 2.

from water surfaces: Blaney, H. F., 1, 2, 4, 5; Harbeck, G. E., Jr., 3; Kohler, M. A., 1.

research: Davis, J. R., 2.

snow cover: Williams, G. P., 2.

suppression: Beadle, B. W.; Berger, B. B.;

Engineering News-Record, 8; Florey, Q. L.;

Garstka, W. U., 1; Harbeck, G. E., Jr., 2;

Heath, W. A.; Kerr, R. E., Jr.; Ludzack, 
Evaporation-Continued.

F. J., 1; Moran, W. T.; Roberts, W. J.; Stephens, U.; Timblin, L. O., Jr., 1, 2; U.S. Bureau of Reclamation, 8, 11, 13, 14, 17. suppression, toxicity: U.S. Bureau of Reclamation, 15.

Evapotranspiration. See also Evaporation, Transpiration.

basin total: Rao, B. S.

by crops: Allison, F. E.; Army, T. J.; Harrold,

L. L., 1; Pierce, L. T.; Russell, M. B.; Suomi, V. E.

by forests: Fletcher, P. W.; Kovner, J. L., 1, 2; Lull, H. W., 9; Mondrillo, G.; Trousdell, K. B.

computation: Harold, L. L., 6; Thornthwaite, C. W., 1,3 .

factors affecting: Drinkwater, W. O.; Lemon,

E. R., 2; Tanner, C. B.

measurement: Benton, G. S.; King, K. M.

meteorological aspects: Halstead, M. H.

mountain soils: Marston, R. B., 5 .

research: Davis, J. R., 2.

water balance: Carter, D. B., 1, 2, 3; Thornthwaite, C. W., 2,4; van Hylckama, T. E. A., $1,2$.

Fish and dams: Netboy, A.; Preston, H. A.

Flood control.

arroyo: Carter, R. H., Jr.

by land treatment: Fox, L.; Marston, R. B., 4;

Matson, H. $\mathrm{O}$.

cooperative program: Heard, W. L.

effects of structures: Hartman, M. A., 1.

evaluation: Holtan, H. N., 2.

general: Ford, E. C.

legislation: Brown, C. B., 2; Curry, J. J.

methods: Engineering News-Record,

Fleming, R. J., Jr., 2.

Mississippi River: Graves, E. A.; Hardin, J. R.; Lawlor, W. F.

New England: Childs, E. F.; Sibley, A. K., 1. planning: Moore, J. A.

program evaluation: Barnes, L. H.; Hartman, M. A., 2; Holtan, H. N., 1; Jenkins, T. A.; Walker, $\mathrm{R}$.

results: Marston, R. B., 3.

Flood damage: American Insurance Association; Barnes, L. H.

Flood frequency. See also Statistics applications. American rivers: Kuiper, E.

estimation: Whisler, B. A.

formula: Bigwood, B. L., 1, 2.

from rainfall data: Paulhus, J. L. H.

from river forecasting procedures: Kresge, R. F., 1.

regional: Searcy, J. K.; Todd, D. K., 6.

synthetic: Snyder, F. F., 2.

ungaged catchments: Nash, J. E., 2.

Flood insurance: American Insurance Association: Foster, H. A., 1, 2; Kentucky Legislative Research Commission: Koch, A. A.; Neville, J. F.

Flood plains.

definition: Pelletier, C. J.

formation: Wolman, M. G., 1.
Flood plains-Continued.

occupance: White, G. F., 2.

river planning: Lunetta, A. M.

zoning: Adams, H. W., 1; Engineering NewsRecord, 14; Kentucky Legislative Research

Commission; Perrey, J. I., 1; Schuleen, E.P.

Floods. See also listings of individual States.

bridge design: Norton, R. A.

effect of fire: Friedrich, C. A.

effect of frozen soil: Storey, H. C.

emergency repair work: Fleming, R. J., 1.

forecasting: Kohler, M. A., 2.

general: Hoyt, W. G.

hurricane: Clinch, R. L.

hydrologic aspects: Bordne, $\mathbf{E}$.

Kansas City: Barney, K. R.

meteorology: Gilman, C. S.

Northeastern States: Argraves, N. E.,; Dalrymple, T.; Engineering News-Record, 2; U.S. Geological Survey, 10.

Northern States: U.S. Geological Survey, 2.

prediction: U.S. Department of the Army.

routing: Kohler, M. A., 4; Nash, J. E., 1; Ray, W. E.

snowmelt: Rosa, J. M., 1.

United States: U.S. Geological Survey, 17. volume-duration-frequency studies: U.S. Corps of Engineers, 5 .

volume frequency: U.S. Corps of Engineers, 4, 7.

Western States: Engineering News-Record, 3; U.S. Geological Survey, 11.

Florida.

excessive rainfall: Florida Board of Conservation.

floods: Musgrove, R. H.

ground water: Bermes, B. J., 1, 2; Bishop,

E. W.; Leve, G. W.; Lichtler, W. F.; Peek,

H. M., 2; Prugh, B. J., 1, 2; Shea, P. H.;

Tarver, G. R.; Wyrick, G. G.

ground-water quality: Brown, D. W., 3.

legislation: Florida Department of Water Resources.

radar storm analysis: Hiser, H. W., 3.

salt-water encroachment: Klein, H.; Rader, E. $M$.

tidal marshes: Kurz, $\mathbf{H}$.

water: Buswell, A. M., 1.

water control: Scott, H. A.

water law: Maloney, F. E.

water management: Florida Engineering and Industrial Experiment Station.

water resources: Brown, D. W., 2; Florida

Water Resources Study Commission;

Parker, G. G., 2; Peek, H. M., 1; Pride, R. W.

water resources and water quality: Kenner, W. E.

water-resources development: DeGrove, J. M. wells: Peek, H. M., 3.

Flow through porous media.

and heat transfer: De Vries, D. A.

boundary dispersion: Day, P. R., 1 .

capillary flow: Luthin, J. N.; Swartzendruber, D., 1,2 .

diffusion: De Jong, G. de J. 
Flow through porous media-Continued. effect of entrapped gases: Orlob, G. T., 1. experimental: Todd, D. K., 3 . physics: Scheidegger, A. E., 1. sandstone: Englehardt, W, von. statistical theories: Scheidegger, A. E., 2. temperature effect: Hadley, W. A.

theory: Hall, W. A., 2; Phillip, J. R., 1. vertical: Day, P. R., 2

water velocity: Gardner, W. H.

Fog. See Precipitation.

Forecasting. See Runoff, Snowmelt runoff, Streamflow, Water supply.

Forest cover.

effect on streamflow: Bethlahmy, N., 3; Hewlett, J. D.; Johnson, E. A., 2; Kovner,

J. L., 1; Love, L. D., 2; Pitman, A. W. evapotranspiration from: Fletcher, P. W.; Zahner, R., 3.

measurement: Ingebo, P. A.; Lemmon, P. E.; Worley, D. P.

snow accumulation: Anderson, H. W., 7. surveys: Swantje, H.; Willingham, J. W.

Forest management. effect on infiltration: Seigworth, K. J.

Forests.

and streamflow: Lull, H. W., 3, 10.

root distribution: Berndt, H. W.

water deficiencies: Zahner, R., 2.

watershed management: Heilman, J. M.; Hopkins, W., 3; Nelson, A. W., Jr.; Trimble, G. R., Jr., 2; Weitzman, $\mathrm{S}$.

watershed problems: Tripp, N. R.; Wilm, H. G., 2.

watershed research: Goodell, B. C., 4; Harper, V. L.; Reinhart, K. G.

Frequency analysis. See also Flood frequency, Statistics applications. Todd, D. K., 7.

Geochronology: Smiley, T. L.

Geohydrology: Linehan, D.

Geomorphology: Coates, D. R., 2; Cotton, C. A.; Kabelac, O. W.; Leopold, L. B., 1; Melton, M. A., 1; Miller, J. P.; Schumm, S. A., 2; Tator, B. A.; Wargo, J. G.; Woodruff, J. F. Geophysical investigations: Norris, S. E., 4; U.S. Bureau of Reclamation, 5 .

Georgia.

drought: Thomson, M. T., 1.

ground water: Callahan, J. T., 2.

quality of water: Albert, F. A.

water resources: Georgia Water Law Revision

Commission; LeGrand, H. E., 2; Thomson, M. T., 2, 3 .

Glaciers.

arctic: Cook, J. C.; Sharp, R. P., 1.

atlas: Field, W. O.

energy transfer: Hubley, R. C.

fluctuations: Heusser, C. J.; Long, W. A.;

Muntz, A. P.; Sharp, R. P., 2.

mapping: Camp, F. A.; Case, J. B.; Colcord,

J. E.; Servisi, J. A.

observations: Giles, G. C.

research: Baird, P. D.; Meier, M. F.

thickness: Thiel, E.
Ground water. See also Artesian water, Drainage,

Flow through porous media, Radioactivity,

Water, listings of individual States.

analog plotter: Mack, L. E.

and flood flow: Todd, D. K., 2.

bibliography: Vorhis, R. C.

flow in fractures: Dehlinger, $P$.

fluctuations: Manson, P. W.

general: Merriam, C. F.; Salzman, M. H.; Thomas, H. E., 1.

geophysical investigations: Buhle, M. B. Todd, D. K., 1.

hydraulics: Wright, K. R.

investigations: Guyton, W. F.; Norris, S. E., 3; von Buttlar, H., 2.

irrigation aspects: $\mathrm{McDonald}, \mathrm{H}$. $\mathbf{R}$.

levels: Richardson, R. M.; Rorabaugh, M. I., 1; Stallman, R. W.

location from airphotos: Howe, R. H. L., 1, 2. location techniques: Spanski, R. F.

movement: Edwards, D. H.; Kaufman, W. J., 2; Werner, P. W.

primary water: Mann, J. F., Jr.

problems: Graham, J. B., 1; Walkinshaw, W. M.

pumping: Muckel, D. C., 1.

replenishment: American Water Works Association, 2; Baffa, J. J.; Baumann, P.; Crooke, H. W.; Hall, W. A., 4, 5; Johnson, C. E.; Krieger, J. H.; Krone, R. B.; Laverty, F. B., 2; Muckel, D. C., 2; Muegge, O. J.; Raymond, J. R.; Scalapino, R. A.; Schiff, L., 1, 2, 4; Sisson, W. H.; Suter, M., 1, 2; University of Oklahoma; Welsch, E. F.

salt-fresh interface: Eriksson, E.; Palmer, H. S.; Schlanger, S. O.

storage: Walker, E. H., 2.

supply development: Kazmann, R. G., 1; Leggette, R. M.

tracers: Kaufman, W. J., 1; von Buttlar, H., 1. trends: Fishel, V. C., 2.

use: Picton, W. L.

utilization: Fiedler, A. G.; Kazmann, R. G., 2; Milligan, C. H., 1; Thomas, R. O., 1.

Ground-water hydraulics: Boreli, M.; Hantush, M. S., 1, 2, 3 .

Hailstorms: Flora, S. D.; Hull, B. B.

Hawaii.

ground water: Palmer, H. S.

rainfall: Baer, $\mathrm{L}$.

water supply: Morgan, E. J.

Hurricanes.

and flooding: Clinch, R. L.; U.S. Weather Bureau, 2.

and rainfall: Schoner, R. W.

and tides: Conner, W. C.; Harris, D. L., 4, 5;

Hoover, R. A.

bibliography: Nupen, W.

general: Gentry, R. C., 2; Tannehill, I. R., 2, 3. protection from: McAleer, J. B.; U.S. Weather Bureau, 5.

water levels accompanying: Harris, D. L., 1; Redfield, A. C.; Zetler, B. D.

wind: Gentry, R. C., 1. 
Hydraulic engineering: Lane, E. W., 1; Linsley, Illinois.

R. K., Jr., 1.

Hydraulic laboratories.

flumes: Fenwick, G. B.

mapping sand beds of flumes: Thompson, M. $M$.

Hydraulic research.

drop inlet: Nelson, G. H.

overland flow: Ree, W. O.

particle motion: Ippen, A. T., 1 .

Hydraulics.

backwater from bridges: Liu, H. K., 2.

culverts: Carter, R. W.; Higliway Research Board; Li, W. H., 2; West, E. M.

estuarine: Simmons, H. B.

flow formulas: Irmay, $\mathrm{S}$.

fluid meclianics: Kindsvater, C. E., 3.

ground water: Walton, W. C.

history: Rouse, $\mathrm{H}$.

measuring devices: Larson, C. L.; Morse, R. M.; Robinson, A. R., 3; Stull, K. S.; Swengel, R. C.

open-cliannel constrictions: Kindsvater, C. E., 1; Tracy, H. J., 1.

open-channel flow: Amein, A. M.; Cariño, I. D.; Cliow, V. T., 2; Cowan, W. L.; Einstein, H. A., 4; Escoffier, F. F., 1, 2; Gauthier, F. B.; Ippen, A. T., 2; Li, W. H., 1; Liu, H. K., 3; Orlob, G. T., 3; Powell, R. W.; Straub, L. G., 1, 2, 3; U.S. Bureau of Reclamation, 12.

open channels: Delleur, J. W.

spillways: Blaisdell, F. W.; Crowley, C. D.; Jansen, R. B.

weirs: Kandaswamy, P. K.; Kindsvater, C. E., 2; Long, L. W.; Stevens, J. C.; Tracy, H. J., 2; Witlierspoon, D. F., 1.

Hydrocliemistry: Clilingar, G. V., 1.

Hydrograpl analysis: Snyder, W. M.

Hydrologic budget: Andreasen, G. E.

Hydrologic laboratory: Dils, R. E., 2.

Hydrology.

data compilation: Jolınson, E. A., 1.

data programs: Langbein, W. B., 4.

data transmittal: Dale, J. A.; Hanes, F. P.; U.S. Corps of Engineers, 9, 12.

general: Ackermann, W. C., 2; Butler, S. S.; Kuenen, P. H.; Linsley, R. K., Jr., 3.

Mekong River basin: Darling, $H$. V. operational economy: Blancliard, F. B. personnel training: Wilm, H. G., 1. research methods: Craig, $\mathrm{H} ., 1$. small watersheds: Twichell, $T$. vocabulary: Sweet, J. S., 1, 2. Ice.

anclior: Benson, N. G.

breakup: Brown, R. J. E.

lake: Bryson, R. A., 2.

thickness: Stevens, H. W., 1.

Idaho.

ground water: Crostliwaite, E. G., 1, 2; Kinnison, P. T.; Littleton, R. T.; Nace, R. L., 1. phreatopliytes: Mower, R. W. springs: Nace, R. L., 2.

water law: Hutchins, W. A., 5. cloud distribution: Changnon, S. A., Jr., 1. drought: Hudson, H. E., Jr.

duration curves: Mitchell, W. D.

floods: Daniels, W. S.

ground water: Bergstrom, R. E., 1, 2, 3; Foster, J. W.; Hackett, J. E.; Hanson, R.; Pryor, W. A., 1, 3; Selkregg, L. F.

irrigation: Black, R. D.

lake-level fluctuations: Sasman, R. T.

maximum station precipitation: U.S. Weatler Bureau, 7.

radioactivity: Frencl, R. R.; Lucas, H. F., Jr.; Vaughn, J. C.

storm analysis: Huff, F. A., 8.

storms: Huff, F. A., 2; Larson, B. O.

thunderstorm precipitation: Changnon, S. A., Jr., 2; Huff, F. A., 7.

water quality: Larson, T. E., 2, 3.

water resources: Ackermann, W. C., 4; Bartell, S. M.; Illinois State Water Survey Division. Indiana.

floods: Daniels, W. S.; Schoppenliorst, C. E. geomorplology: Coates, D. R., 2.

ground water: Rosenslein, J. S.

lakes: Perrey, J. I., 2.

maximum station precipitation: U.S. Weatler Bureau, 7.

water levels: Indiana Division of Water Resources.

water resources: Indiana Water Resources Study Committee; Roberts, C. M.

Infiltration.

during irrigation: Hansen, V. E.

effect of crop cover: Ayers, H. D., 1 .

effect of forest management: Seigwortl, K. J.

effect of lieat: Scott, V. H., 1, 2.

effect of soil frost: Trimble, G. R., Jr., 4.

effect of tillage practices: Musgrave, G. W., 3. effect of water-storage capacity: Ayers, H. D., 2.

field definition: Marston, R. B., 1, 2; Swartzendruber, D., 3.

forest lands: Rauzi, F., 1, 2.

frequency: Johnson, H. P.

general: Musgrave, G. W., 1, 2; Williams, D. A., 4.

induced: Rorabaugl, M. I., 2.

moisture profiles: Youngs, E. G.

theory: Hall, W. A., 3; Philip, J. R., 3, 4, 5, 6 , $7,8,9$.

Infiltrometers: Adams, J. E.; Aronovici, V. S.; Bondurant, J. A.; Burgy, R. H., 1; Haise, H. R., 2.

Insolation: Mateer, C. C.

Interception. See also Rainfall.

Burgy, R. H., 3.

Iowa.

drouglits: Baumann, E. R.

floods: U.S. Geological Survey, 9; Yost, I. D. ground water: Hale, W. E., 1; Walker, E. H., 1. low flows: Scliwob, H. H. quality of water: Iowa Geological Survey. soil moisture: Sliaw, R. H.

water problems: Schaller, F. W. 
Iowa-Continued. water resources: Iowa Natural Resources Council, 1, 2, 3, 4, 5, 6; Timmons, J. F.

Irrigation.

and pollution: Wiseman, J. W.

brackish water: Lunin, J.

engineering: Houk, I. E.

ground-water use: Anderson, K. E., 1.

humid areas: Beauchamp, K. H.; Davis, J. R. 1; Quackenbush, T. H.; Rubey, H.

infiltration: Diebold, C. H.; Hansen, V. E.

return flows: U.S. Bureau of Reclamation, 2. subirrigation systems: Fox, R. L.; van't Woudt, B. D., 2.

supplies: Law, W. P., Jr.

system evaluation: Criddle, W. D., 2.

water budget: Thornthwaite, C. W., 1.

water measurement: Dusenberry, H. L.; Thomas, C. W.

water quality: Cole, R. C.; Wadleigh, C. H. water requirements: Robertson, G. W.; Snow, B. C.

with sewage: Nordyke, L.

Juvenile water. See Water.

Kansas.

droughts: Metzler, D. F., 2.

ground water: Bayne, C. K., 1, 2; Bradley E.,

2; Dufford, A. E.; Fishel, V. C., 1; Johnson,

C. R.; O'Connor, H. G.; Prescott, G. C., Jr.;

Stramel, G. J., 1, 2, 3; Verville, G. J.;

Walters, K. L.

ground-water levels: Fishel, V. C., 3.

Kansas Basin project: University of Kansas. stream-gaging program: Furness, L. W., 2. water law: Kansas Water Resources Board, 1. water problems: Kansas Water Resources Board, 3, 4 .

water quality: Metzler, D. F., 3.

water resources: Kansas Water Resources

Fact-finding and Research Committee.

Kentucky.

ground water: Baker, J. A., 1; Harvey, E. J., 1 ;

Pree, H. L.; Price, W. E., Jr.; Rorabaugh,

M. I., 2; Walker, E. H., 3, 4.

ground-water storage: Walker, E. H., 2.

maximum station precipitation: U.S. Weather

Bureau, 7.

streamflow: Kentucky Department of

Economic Development.

water quality: Collier, C. R.

water supplies: Baker, J. A., 2.

Labrador geography: Nutt, D. C.

Lakes. See also Limnology.

bottomless: Harrington, E. R.

effect of irrigation: Anderson, K. E., 2.

forced circulation: Riddick, T. M.

hydrology: Perrey, J. I., 2.

movement of water: Bryson, R. A., 1.

Ontario regulation: Snyder, F. F., 1.

oscillations: Bottomley, G. A.

sediment movement: Manohar, $M$.

thermal regime: Brewer, M. C.

water-level fluctuations: Harris, D. L.; Sasman, R. T.

Land use.

changes: Earle, J. B.
Land use-Continued.

effect on streamflow: Lull, H. W., 4; Rosa, J. M., 2.

Law.

drainage: Ohio Legislative Service Commission, 2.

international: American Society of International Law; MeNaughton, A. G. L.

treaties and interstate compacts: Witmer, T. R. underground water: Harding, S. T.; Holsinger, H.; McLaughlin, T. G., 2; Perry, R.; Water Works Engineering, 2.

water: Bechert, C. H.; Blair, M. B.; Busby, C. E., 1, 2; Callahan, C. C.; Chapman, C. W.; Critchlo.., H. T.; Duke University School of Law; Ellis, H. H.; Engineering News-Record, 11; Florida Department of Water Resources; Georgia School of Law; Guess, C. P., Jr.; Haber, D.; Hamming, E.; Hutchins, W. A., 1, 2, 3, 4, 5, 6; Kansas Law Review; Kansas Water Resources Board. 1; Kuder, W. B.; Love, C. L.; Maloney, F. E.; Merryfield, F.; Milmoe, W.; North Carolina Division of Water Resources, Inlets, and Coastal Waterways, 5; Ohio Legislative Service Commission, 1; Pepper, J. W.; Texas Board of Water Engineers, 1; Texas University School of Law; Wolman, A., 2.

watershed conservation: Brown, C. B., 1; Steele, H. A.

Limnology. See also Lakes.

currents: Ayers, J. C.

general: Hutchinson, G. E.; Vallentyne, J. R. glacial lake: Mathews, W. H.

marshes: Kurz, H.

physical: Lauff, G. H.

sediments: Eardley, A. J.; Murray, R. C.

waves: Donn, W. L.

Louisiana.

ground water: Fader, S. W., 1, 2, 3; Klug, M. L.; Meyer, R. R.

maximum station precipitation: U.S. Weather Bureau, 7.

water problems: Louisiana Legislative Council water resources: Eddards, M. L.; Jones, P. H.;

Louisiana Department of Public Works; Louisiana Engineering Experiment Station, $1,2$.

Lysimeter investigations: Harrold, L. L., 7; King, K. M.

Lysimeters: Allison, L. E.

Manitoba soil temperatures: Beckel, D. K. B.

Maryland.

hydrologic budget: Andreasen, G. E.

water resources: Dingman, R. J., 2; Maryland Special Commission; Otton, E. G.; Overbeck, R. M.; Rasmussen, W. C., 1, 3. watershed control: Ningard, L. G.

Massachusetts.

ground water: Massachusetts.

water-resource program: Sterling, C. I., Jr.

Mekong River basin: Darling, H. V.

Michigan.

ground water: $\quad$ Deutsch, M., 2; Vanlier, K. E., 1, 2. 
Michigan-Continued. pollution: Deutsch, M., 1 .

water resources: Michigan Water Resources Commission, 1, 2.

watershed studies: Ash, A. S.

Minnesota.

ground water: Manson, P. W.; Schneider, R.; Straka, G. C.

soil freezing: Bay, R. R., 3.

Mississippi.

flood prevention: Heard, W. L.

fresh-water strata: Priddy, R. R., 2.

ground water: Harvey, E. J., 2.

maximum station precipitation: U.S. Weather

Bureau, 7.

sediment yield: Woodburn, R., 1.

sediments: Priddy, R. R., 1.

water law: Pepper, J. W.

water resources: Lang, J. W.; Mississippi

Board of Water Commissioners; Mississippi

Water Resources Policy Commission.

Mississippi Valley, water utilization: Zadrozny, M. G.

Missouri.

droughts: Muilenburg, G. A.

floods: Searcy, J. K.

Missouri River basin.

development: Maffitt, D. L.

development policy: Ridgeway, M. E.

floods: U.S. Corps of Engineers, 2; U.S.

Geological Survey, 1.

plan: Johnson, W. E., 2.

problems and programs: Engineering News-

Record, 4; Hart, H. C.

reservoirs: Edstrand, J. P.; Johnson, W. E., 1;

Pafford, R. J., Jr.

water quality: Hatcher, M. P.; Hopkins, G. J.

water resources: Ferguson, G. E., 1.

Montana.

floods: U.S. Geological Survey, 14

ground water: Groff, S. L.; Lorenz, H. W.;

Moulder, E. A.; Swenson, F. A., 1, 3;

Torrey, A. E.; Zimmerman, E. A.

ground-water law: Groff, S. L.

water quality: Lorenz, H. W.; Moulder, E. A.;

Swenson, F. A., 1, 3; Torrey, A. E

water resources: Montana State Engineer, 1, 2, 3,4 .

Morphology: Lane, E. W., 1.

Nebraska.

floods: Furness, L. W., 1.

ground water: Bjorklund, L. J., 2, 3; Bradley, E., 1, 3; Brown, D. W., 1; Cronin, J. G.; Newport, T. G.; Schreurs, R. L.; Sniegocki, R. T.

sediment transport: Mundorff, J. C.

water legislation: Jones, D. S.; Perry, R.

water quality: Bjorklund, L. J., 2, 3; Bradley,

E., 1; Brown, D. W., 1; Cronin, J. G.; Newport, T. G.; Schreurs, R. L.; Sniegocki, R. T. water resources: University of Nebraska. well logs: Smith, F. A.

well records: Reed, E. C.

Network analysis: Rowe, P. P.

Nevada.

consumptive use: Houston, C. E.
Nevada-Continued.

floods: U.S. Geological Survey, 12.

ground water: Visher, F. N.

water rights: Hutchins, W. A., 1.

New England.

floods: Fleming, R. J., Jr., 2.

water resources: New England-New York Inter-Agency Committee.

water supply: Water Works Engineering, 3 .

watershed management: Lull, H. W., 11.

New Jersey.

evapotranspiration: Lull, H. W., 9.

irrigation: Hardman, R. L.

water-supply development: Meyner, R. B.

New Mexico.

climatic trends: Von Eschen, G. F.

climatological summary: New Mexico State

Engineer, 1, 2.

geomorphology: Miller, J. P.

ground water: Bjorklund, L. J., 1; Bushman,

F. X.; Callahan, J. T., 1; Conover, C. S.

Hale, W. E., 2; Reeder, H. O.; Smith, R. E.; Spiegel, Z.

Roswell artesian basin: Bean, R. T.

water rights: Hutchins, W. A., 2.

watershed management: Dortignac, E. J., 2.

weather modification: Buell, C. E.

New York.

floods: U.S. Geological Survey, 18.

forest watershed problems: Wilm, H. G., 2. ground water: Asselstine, E. S.; Upson, J. E., 1; Welsch, E. F.

ground-water conservation: Johnson, A. H.

irrigation: New York State, 2.

water law: Milmoe, W.

water quality: Hazen, R., 1; Hoffman, J. F. water resources: New England-New York Inter-Agency Committee; New York State, 1.

well correlation: Tesmer, I. H.

North Carolina.

evapotranspiration by pine: Trousdell, K. B. ground-water resources: LeGrand, H. E., 3. maximum station precipitation: U.S. Weather Bureau, 7.

quality of water: McAvoy, R. L. water-quality standards: North Stream Sanitation Committee.

water resources: Billingsley, G. A.; Fish, R. E.; North Carolina Board of Water Commissioners, 1, 2; North Carolina Division of Water Resources, Inlets, and Coastal Waterways, $1,2,3,4$.

well logs: Brown, P. M.

North Dakota.

ground water: Dingman, R. J., 1; Paulson, Q. F.; Powell, J. E.

saline-water resources: Robinove, C. J.

soil temperatures: Potter, L. D.

streamflow data: North Dakota Water Conservation Commission.

water quality: Dingman, R. J., 1; Swenson, F. A.

Northwest Territories, soil temperatures: Cook, F. A. 
Ohio.

aquifers: Norris, S. E., 2.

drainage law: Ohio Legislative Service Commission, 2.

droughts: Williams, L. G., 1.

evapotranspiration: Pierce, L. T.

ground water: Kaser, P.; Norris, S. E., 1. ground-water contamination: Ulrich, A. A. maximum station precipitation: U.S. Weather Bureau, 7.

pollution control: Cleary, E. J., 1; Moulton, E. Q.; Ohio Legislative Service Commission, 3.

reservoir sedimentation: Hahn, C. L.

stream sediment: Lamar, W. L., 2.

underground water law: Water Works Engineering, 2.

water resources: Schmidt, J. J.

water rights: Callahan, C. C.; Ohio Legislative Service Commission, 1.

water supplies and pollution control: Waring, F. $\mathrm{H}$.

Ohio River basin.

evapotranspiration: Rao, B. S.

flood control: Gilcrest, B. R.

water quality: Cleary, E. J., 2, 3.

Oklahoma.

evaporation suppression: U.S. Bureau of Reclamation, 8.

flood prevention: Holtan, H. N., 2; Walker, R. ground water: Davis, L. V.; Reed, E. W. ground-water development: Davis, K. C. water quality: Dover, T. B.

water rights: Hutchins, W. A., 3 .

watershed management: Kautz, H. M.

Ontario.

ground-water problems: Walkinshaw, W. M. maximum precipitation: Bruce, J. P.

water legislation: Berry, A. E., 2.

Oregon.

maximum station precipitation: U.S. Weather Bureau, 7.

water law: Merryfield, $F$.

water quality: Northeraft, $M$.

water resources: Griffin, W. C.

weather modification: Decker, F. W.; Woodbridge, D. D.

Pecos River basin: Harrington, E. R.; Pecos River Commission.

Pennsylvania.

forest and water research: Lull, H. W., 6; Pennsylvania Department of Forests and Waters.

forests and floods: Lull, H. W., 7 .

ground water: Greenman, D. W.; Pennsylvania Topographic and Geologic Survey; Rima, D. $\mathbf{R}$.

maximum station precipitation: U.S. Weather Bureau, 7.

variation in runoff: Lull, H. W., 4.

Permafrost and ground water: Hopkins, D. M.

Permeability.

determination: Franzini, J. B.; Rose, H. G.

effect of organic matter: Smith, F. B.

measurement: Corey, A. T.; Johansen, R. T.
Phreatophytes: Fletcher, H. C.; Robinson, T. W. Thompson, C. B.; U.S. Bureau of Reclamation, 22.

Plants.

grow th factors: Allison, L. E.

wilting point: Lowry, G. L.

Platte-Arkansas Rivers basin, snow surveys: Stockwell, H. J., 2.

Pollution. See also Radioactivity.

aeration: Scott, R. H.

computation: Burt, W. B.

control: American Society for Testing

Materials, 3; Hoak, R. D., 2; Hollis, M. D.;

Louisiana Engineering Experiment Station,

3; Ohio Legislative Service Commission, 3;

Rawn, A. M.; Waring, F. H.; Wise, W. S.;

Young, L. A.

dispersal: Niles, T. M.

general: Berry, A. E., 1; Klein, L.; Schwob, C. E.

ground water: Fournelle, H. J.; Ulrich, A. A.; Welsch, W. F.

legal implications: Geuther, C. E.; Owen, G. E. literature: FSIWA Committee on Research, $1,2$.

mine drainage: Moulton, E. Q.

oil-refinery effluents: Ludzack, F. J., 2.

radioactive materials: Bryant, G. T.; Deutsch, M., 1; Hess, H. H.; Prout, W. E.

reaeration: O'Connor, D. J.; Rand, M. C.

stream: Gaufin, A. R., 1, 2.

stream purification: Lueck, B. F.

surveys: Rich, L. G.

Power development: U.S. Federal Power Commission; Wardle, J. M.; Weaver, F. L.

Power distribution: Montana University School of Law.

Power production.

economics: Jaeger, C.

tidal power: Millar, G.

Precipitation.

average: Franceschini, G. A.

changes: Dingle, A. N.

characteristics: Harrold, L. L., 2.

depth area duration: Clark, R. A.

estimation: McDonald, J. E., 2.

fog drip: McIntosh, R. P.

fog, mist, and dew: Patton, C. P.; Went, F. W. forecasting: Denison, P. J.

gages: Allen, F. C.; Huff, F. A., 1, 3; Kresge,

R. F., 2; Ursic, S. J.; Warnick, C. C.

index of variation: Schloemer, R. W.

maximum: Bruce, J. P.

maximum station: U.S. Weather Bureau, 7.

measurement: Hamilton, E. L.; Hiatt, W. E.; Wilson, W. T., 1.

processes: Mook, C. P.

radar interpretation: Stout, G. E.

rate: Boyd, D. W.; Peterson, K. R.

storm: U.S. Corps of Engineers, 11.

storm characteristics: Boyer, M. C., 1.

tree rings: Bowers, N. A.; Wiksten, A.

trends: Diamond, $M$.

type distributions: Hiser, H. W., 1.

variability: McDonald, J. E., 1. 
Pumping tests: Hantush, M. S., 4; Remson, I., 2. $\mid$ Rainfall-Continued.

Quality of water.

analysis: Lamar, W. L., 1.

classification: Chilingar, G. V., 2.

Columbia River basin: Sylvester, R. O.

data: U.S. Inter-Agency Committee on Water Resources, 1.

data program: Palange, R. C.

effect of hexadecanol: U.S. Bureau of Reclamation, 10.

effect of storage: Churchill, M. A.; Hatcher, M. P.; Ingols, R. S.

effect on metals: Streicher, L.

estimated by resistivity: Pryor, W. A., 2.

for aquatic life: ORSANCO Aquatic Life Advisory Committee, $1,2$.

for industry: American Society for Testing Materials, 2.

for irrigation: Doneen, L. D.; U.S. Geological Survey, 3, 7, 16, 24; Wadleigh, C. H.

for subsurface injection: University of Oklahoma.

general: Brown, H. B.

monitoring: Hartung, H. O.

program: Hanson, E. L.

public supplies: Lohr, E. W.

relation to elevation: Wilcox, J. C.

relation to forests: Everts, C. M., Jr.

relation to geology: LeGrand, H. E., 4.

reporting: Chilingar, G. V., 3.

Radar.

rainfall measurements: Hiser, $H$. W., 2; Huff, F. A., 5; Mueller, E. A.

storm interpretation: Austin, P. M.; Bigler, S. G.; Hiser, H. W., 3, 4; Ligda, M. G. H.; Stout, G. E.

tornado observation: Schuetz, J.

Radioactivity. See also Pollution.

determination: Hahn, R. B.

in rainfall: Rosenthal, B. L.; Setter, L. R., 3.

in water: Barker, F. B., 1, 2; Bell, C. G., Jr.; Eliassen, R.; Judson, S.; Kramer, H. P.; Nichols, M. S.; Setter, L. R., 1, 2; Vaughn, J. C.

instrumentation: American Water Works Association, 1.

radiotracers: Parker, F. L.; Simpson, E. S. sediments: Garner, J. M., Jr.

Rainfall. See also Precipitation.

analysis: Huff, F. A., 8.

and floods: U.S. Weather Bureau, 2, 8.

depth-duration relationships: Corn, H. M.

energy: Wischmeier, W. H., 3.

excessive: Florida Board of Conservation.

forecasting: Swayne, W. W.

frequency: Huff, F. A., 4.

from hurricanes: Schoner, R. W.

intensity: Linsley, R. K., 2; U.S. Weather Bureau, 3.

intensity-duration-frequency: U.S. Weather

Bureau, 1, 6.

intensity synthesis: Hershfield, D. M.

mineral composition: Larson, T. E., 1.

orographic: Baer, L.

point: Huff, F. A., 6.

probabilities: Friedman, D. G.

relation to runoff: Cox, M. B.; Hazen, R., 2; Miller, J. F.; Smith, J. L.

simulator: Adams, J. E.; Meyer, L. D.

small areas: Huff, F. A., 7.

stations needed: Wilkinson, J. H.

variation: American Society of Civil Engineers, 1.

Range management: Grenier, A. R.; Harper V. L.; Love, L. D., 4; Monson, O. W.; Renner, F. G.; Wingfield, D. W.

Research.

agricultural water problems: Salter, R. M.

arctic: Arctic Institute of North America.

climatology: Craig, H., 2.

glaciological: Baird, P. D.

hydrologic: Craig, H., 1.

sediment hydraulics: Carlson, E. J.; Chien, N., 1.

water resources: Barnes, C. P.; California University Committee on Research in Water Resources; Taylor, E. H.; University of California, 1, 2.

watershed: Dunford, E. G., 2; Gregory, G. R. Reservoirs: Edstrand, J. P.; Harleman, D. R. F.; Koelzer, V.A., 2; Pafford, R. J., Jr.; Thomas, N. $O$.

Rhode Island, ground water: Allen, W. B.; Bierschenk, W. H., 1.

Rio Grande basin, snow surveys: Stockwell, H. J., 3.

River basin.

development: Foote, L. H.; Fry, A. S.; McNaughton, A. G. L.; United Nations, 2. reservoir operation: Clendenen, $F$. B.

River-bed degradation: Mostafa, M. G.; Witzigman, F. S., 3.

River forecasts: Hopkins, C. D., Jr.

River models: Einstein, H. A., 2.

River profiles: Hack, J. T.; Shulits, S.; Yatsu, E.

River-project design: Langbein, W. B., 6.

River surveys: Matthes, G. H.

Rivers. See also Channels.

Brittain, R.; Kabelac, O. W.

Runoff. See also Streamflow, Water supply.

characteristics: Raudsepp, W.; Stage, A. R. determined from rainfall: Whelan, D. E., 1. effect of cover: Smith, F. B.

effect of fire: Anderson, J. W., 1; Biswell, H. H.; Sinclair, J. D.

factors affecting: Hays, O. E., 1; Lull, H. W., 4. from cultivated land: Allis, J. A.; Medlock, o. C.

from forested land: Rowe, P. B., 1; Varney, G. L.; Weitzman, S., 2.

from plots: Bertoni, J.; Witherspoon, D. F., 2. prediction: Arden, R. S.; Cavadias, G. S., 3. sampler: Barnes, K. K.; Parsons, D. A.

variations: Burford, J. B.; Langbein, W. B., 2. volumes: U.S. Corps of Engineers, 13.

Saline-water conversion: Copeland, W. R.; Curran, B. H. M.; De Jong, T.; Engineering News-Record, 6, 10, 15; Gilliland, E. R.; Howe, E. D.; Jenkins, D. S., 1, 2, 3; Moyers, W. H.; Powell, S. T.; Smith, D. B., 1, 2, 3; University of Maryland. 
Salt-water intrusion: Banks, H. O., 1; Black, A. P.; Borg, S. F.; California Department of Water Resources, 11; Glover, R. E.; Klein, H.; Laverty, F. B., 1; Parker, G. G., 1; Wentworth, C. K.; Willets, D. B.; Winslow, A. G., 2.

Sand channels. See also Channels.

bed mapping: Thompson, M. M. laboratory flume: Fenwick, G. B.

Sediment.

delivery rates: Maner, S. B.

effects of land use: Cooper, A. J.; Larson, F. H. exclusion from canal: U.S. Bureau of Reclamation, 19.

load computations: Colby, B. R., 1; Schroeder, K. B.

Mississippi Sound: Priddy, R. R., 1.

problems: Brune, G. M.; Einstein, H. A., 3; Woodburn, R., 3.

radioactivity: Garner, J. M., Jr.

records: U.S. Corps of Engineers, 10.

reservoir: Witzigman, F. S., 2.

size analysis: Colby, B. C.; U.S. Inter-Agency Committee on Water Resources, 4.

suspended: Lamar, W. L., 2; Marris, A. W. total load: Benedict, P. C., 1; Laursen, E. M., 1.

transport: Benedict, P. C., 2; Chien, N., 1; Colby, B. R., 3; Einstein, H. A., 1; Heidel, S. G.; Laursen, E. M., 2; Stall, J. B.; U.S. Bureau of Reclamation, 23; Vanoni, V. A. yield: Anderson, H. W., 3; Gottschalk, L. C., 2; Langbein, W. V., 3; Woodburn, R., 1.

Sediment sampling.

equipment: Bader, R. G.; Williams, J.

laboratory apparatus: U.S. Inter-Agency Committee on Water Resources, 3.

tidal waterways: Schultz, E. A., 1.

Sedimentation.

data: U.S. Corps of Engineers, 8.

estuaries: Schultz, E. A., 2.

measurement: Gottschalk, L. C., 1; U.S. Bureau of Reclamation, 16.

research: Ackermann, W. C., 3; Bloodgood, D. E.; Carlson, E. J.

reservoir surveys: Renfro, G. W.; U.S. Bureau of Reclamation, 24; U.S. Inter-Agency Committee on Water Resources, 2.

reservoirs: Borland, W. M., 1; Brown, C. B., 3; Flaxman, E. M.; Fowler, L. C.; Hahn, C. L.; Koelzer, V. A., 3; Livesey, R. H.; McCain, E. H.; Mundorff, J. C.; Witzigman, F. S., 1. survey: U.S. Corps of Engineers, 14.

theory: DallaValle, J. M.; McGauhey, P. H., 1. Seepage.

canal: Robinson, A. R., Jr., 1.

levees: Mansur, C. I., 1.

measurement: Robinson, A. R., Jr., 2.

reduction: Lauritzen, C. W.; U.S. Bureau of Reclamation, 18.

Snow.

albedo: Dunkle, R. V.; Jackson, C. I.

avalanches: Borland, W. M., 2.

bibliography: Sherrod, J., Jr., 1, 2.

hydrology: Brown, H. E.; Johnson, O.; U.S. Corps of Engineers, 6.
Snow-Continued.

management research: Anderson, H. W., 9.

measurements: LaChapelle, E.; Sartz, R. S., 2. melt: Hildebrand, C. E.; Jencks, C. E.; U.S.

Corps of Engineers, 3; Weiss, L. L., 3.

physical characteristies: Gold, L. W.

removal: Stackhouse, J. L.

research: Shaw, E. W.

studies: Walsh, K. J.

water content: Williams, G. P., 1.

Snow accumulation.

and climate: Miller, D. H., 1.

management: Anderson, H. W., 5, 8; Bay,

R. R., 1.

relation to forests: Anderson, H. W., 2, 4, 6, 7;

Baldwin, H. I.; Bay, R. R., 2; Dils, R. E., 1;

Goodell, B. C., 1, 2; Miner, N. H.; Pierce,

R. S., 2; Sartz, R. S., 1.

snowpack index: Hannaford, J. F., 2.

Snow surveying.

applications: Frederickson, D. G.; Irving, R. N. equipment: Cavadias, G. S., 1.

helicopters: Dean, W. W.; Miller, R. W.

methods: Beaumont, R. T., 1; Court, A., 2;

Engineering News-Record, 16; Work, R. A.,

1, 2, 3; Wyckoff, P.

planning: Codd, A. R.

training: Davis, R. T.

Snowfall.

Canada: Potter, J. G.

threshold: Thom, H. C. S., 1.

trends: Ashley, R. E.

Snowmelt runoff. See also Runoff, Water supply. factors affecting: Garstka, W. U., 2; Koelzer, V. A., 1; Zimmerman, A. L.; Zoller, J. H. prediction: Andrew, A. N.; Cavadias, G. S., 2; Chard, A. E.; Clark, R. H.; Nelson, M. W.; Peak, G. W.

Soil.

absorption of radioactive wastes: Prout, W. E. cover: Kittredge, J.

evaporation from: Veihmeyer, F. J., 2.

freezing: Bay, R. R., 3; Drew, J. V.; Jumikis,

A. R.; Pierce, R. S., 1, 2; Sartz, R. S., 3; Stoeckeler, J. H.

heat conductivity: Buettner, K., 1, 2; Jaeger,

J. C.; Lachenbruch, A. H.; Portman, D. J. permeability: American Society for Testing

Materials, 1; Corey, A. T.; Mansur, C. I., 2. physics: Baver, L. D.

properties: Doss, B. D.; Taylor, R. E.; Thames, J. L., 2.

sampler: Andrews, L. A.

size distribution: Beavers, A. H.; Johnson, R. W.

structure: Brill, G. D.; Domby, C. W.; Dyrness,

C. T.; Eschner, A. R.; Scott, V. H., 2.

surveys: Nelson, R. E.

temperatures: Beckel, D. K. B.; Chang, J.; Cook, F. A.; Crawford, C. B.; Penrod, E. B.; Potter, L. D.; Singer, I. A.

Soil and water conservation. engineering: Frevert, R. K.

Forest Service program: Clark, L. K.

general: Allen, S. W.; Bennett, H. H.; Brown,

C. B., 1; Coyle, D. C.; Dale, T.; Dorroh, 
Soil and water conservation-Continued.

J. H., Jr.; Foster, A. B.; Israelsen, O. W.; Jacobsen, T.; Stallings, J. H.; Weinberger, M. L.; Williams, D. A., 2. programs: Williams, D. A., 1. soil surveys: Copeland, O. L., Jr. water rights: U.S. Soil Conservation Service, 2. watershed law: Steele, H. A.

Soil loss.

estimating: Wischmeier, W. H., 2.

forecasting: Van Doren, C. A.

relation to rainfall intensity: Wischmeier, W. H., 3.

Soil moisture. See also Permeability. availability: Lowry, G. L.; Shockley, D. R.; Taylor, S. A., 2.

constants: Broadfoot, W. M.

depletion by trees: Lull, H. W., 9; Zahner, R., $1,3$.

dispersion of solutes: Day, P. R., 3 .

effect of shelterbelts: Staple, W. J.

effect of vegetation: Harrold, L. L., 5; Tarrant, R. F.

estimates: van Bavel, C. H. M., 2.

general: Richards, L. A., 3.

gradient: van't Woudt, B. D., 1 .

losses: Lemon, E. R., 1; Remson, I., 1; Richards, L. A., 2; Shaw, R. H.

measurement: Abd-El-Samie, A. G.; Bender,

M. E., Jr.; Bloodworth, M. E., 3; Bourget,

S. J.; Bouyoucos, G. J.; Burrows, W. C.;

De Plater, C. V.; Haise, H. R., 1; Horton,

J. S.; Lull, H. W., 2; Marston, R. B., 5;

Remson, I., 3; Sivadjian, J.; Stewart, G. L.;

Stolzy, L. H.; Stone, J. F.; Taylor, S. A.;

Thames, J. L., 3; Thorne, M. D.; van Bavel,

C. H. M., 3, 7; Weeks, L. V.

movement: Gardner, W. R., 1, 2, 3; Jordan,

J. V.; Luthin, J. N.; Richards, L. A., 1;

Swartzendruber, D., 1, 2; Woodside, W.;

Youngs, E. G., 2, 3.

potential: Bolt, G. H.

prediction: Carlson, C. A.; Tobiaski, R. A.

regime: Thames, J. L., 1.

replenishment: Grenier, A. R.

surveys: Peters, D. B.

temperature influence: Daubenmire, $\mathbf{R}$.

Solar energy: Fritz, S.

South Carolina, ground water: Siple, G. E,

South Dakota.

ground water: Erickson, H. D.; Koopman,

F. C.; Lee, K. Y., 1, 2, 3; Rothrock, E. P.;

Steece, F. V.; Tipton, M. J.; Tychsen, P. C. water quality: Tychsen, P. C.

Springs: Harris, H. B.; Nace, R. L., 2.

Statistics applications. See also Flood frequency,

Frequency analysis.

correlation: McDonald, J. E., 3.

data processing: Wischmeier, W. H., 1.

Fourier series: Milligan, C. H., 2.

frequency analysis: Andrews, R. G.; Brakensiek, D. L., 2; Chow, V. T., 1, 3; Moran, P. A. P.; Potter, W. D., 2; Rowe, R. R.; Weiss, L. L., 1, 2; Wilson, W. T., 2.
I Statistics applications-Continued.

ground-water levels: Remson, I., 5.

meteorology: Panofsky, H. A.

miscellaneous: Beaumont, R. T., 2; Brakensiek,

D. L., 1; Krumbein, W. C.

reservoir operation: Koelzer, V. A., 2.

sampling: Potter, W. D., 1.

Storage.

economics: Hazen, R., 3.

general: Hill, R. A.

long term: Fathy, A.

pond design: Smith, D. D., I.

queuing theory: Langbein, W. B., 5 .

upland: Williams, L. G., 2.

Stream gaging. See also Current meters.

Langbein, W. B., 2.

Streamflow. See also Runoff.

compilation of records: U.S. Geological Survey, $4,5,6,8,13,15,19,20,21,22,23$.

effect of fire: Sinclair, J. D.

extending data: Langbein, W. B., 1.

forecasting: Clark, W. E.; Milligan, C. H., 2; Van Horn, O. B.

ice storage: Erskine, H. M.

index of records: Bailey, E. G., 1, 2, 3, 4, 5; Gatewood, J. S., 1, 2, 3, 4, 5; Knox, C. E., 1, 2; Matthai, H. F., 1, 2; Speer, P. R., 1, 2. land-use effect: Johnson, E. A., 2; Rich, L. R.;

Rosa, J. M., 2; Whelan, D. E., 2.

measurement: Moore, A. M.

records: Mississippi River Commission.

relation to geology: Schneider, W. J.

routing: Isaacson, E.; Rockwood, D. M., 2.

tidal estuary: Ingerson, I. M.; Todd, D. K., 4. variations: Wilson, $M$. T.

Subsidence of land: Inter-Agency Committee on Land Subsidence; Loehnberg, A., 2; Poland, J. F., 1, 2; Shoemaker, R. R.; Stephens, J.C.

Temperatures. See also Soil, Weather.

forest influence: Miller, D. H., 2.

periodicity: Visser, S. W.

variation: Anderson, L. C.

Tennessee.

ground water: Criner, J. H.; DeBuchananne, G. D.; Newcome, R., Jr., 1, 2.

maximum station precipitation: U.S. Weather Bureau, 7.

quality of water: Lanphere, C. R.

water policy: Public Administration Service.

watershed development: Smith, H. A.

Tennessee Valley Authority: Vogel, H. D.

Texas.

flood control: Barnes, L. H.

floods: Breeding, S. D.; Texas Board of Water Engineers, 3.

ground water: Anders, R. B.; Knowles, D. B.; Leggat, E. R., 1, 2; Long, A. T.; Petitt, B. M., Jr.; Sundstrom, R. W.

ground-water pumpage: Wood, L. A., 1, 2. ground-water use: Texas Board of Water Engineers, 4.

irrigation: Nordyke, L.

pond survey: U.S. Soil Conservation Service, 4. reservoirs: Texas Board of Water Engineers, 2. saline-water resources: Winslow, A. G., 1. 
Texas-Continued.

surface-water records: Texas Board of Water Engineers, 5, 6.

water developments and potentialities: Texas Board of Water Engineers, 7.

water law: Blair, M. B.; Texas Board of Water Engineers, 1; Texas University school of law. water levels: Follett, C. R.; Rayner, F. A., 1, 2; Swartz, B. W., 1, 2.

water problems: Forrest, T. C., Jr.; Nichols, M. C.

water resources: Texas Society of Professional Engineers; Water for Texas Conference. well records: Arnow, $T$.

Thailand, ground water: LaMoreaux, P. E., 2. Tides.

gage records: Harris, D. L., 3.

variation: Disney, L. P.

wind: Sibul, O. J.

Time of flow: Straub, C. P.

Topographic characteristics.

maps: Rowland, J. B.

quantitative parameters: Melton, M. A., 2, 3; Strahler, A. N., 2, 3.

slope analysis: Strahler, A. N., 1.

stream lengths: Morisawa, $\mathbf{M}$.

Transpiration. See also Evapotranspiration.

by phreatophytes: Fletcher, H. C.; Mower, R. W.

from a forest: Yamaoka, Y., 2.

measurement in plants: Bloodworth, M. E., 1, 2; Decker, J. P.

plant physiology: Bernstein, L.

relation to meteorological elements: Yamaoka, Y., 1.

relation to soil moisture: Veihmeyer, F. J., 1.

Tree growth: Glock, W. S.

Tree rings. See also Precipitation.

Schulman, E.; Wiksten, A.

Utah.

drought: Waite, H. A.

flood prevention: Marston, R. B., 4.

floods: U.S. Geological Survey, 12.

ground-water problems: Warnick, F. M.

precipitation: Clark, R. A.

water problems: Criddle, W. D., 5.

water quality: Connor, J. G.

water resources: Clyde, G. D.

Valley, ancient: Amsbary, F. C., Jr.

Vegetation, effect on water yield: Musgrave, G. W., 4 .

Velocity forces: Waterways Experiment Station.

Vermont.

spring flow: Pitman, A. W.

water-table studies: Midgley, A. R.

Virginia.

droughts: Wallace, D. S.

ground water: Cederstrom, D. J.; Subitzky, S. ground-water supplies: Latta, B. F.

water resources: Virginia Advisory Legislative

Council.

water-resources problems: Johnson, W. M. well records: Sinnott, A.

Washington.

glaciers: Heusser, C. J.; Long, W. A.

ground water: Sceva, J. E.
Washington-Continued.

bydrographic data: Washington Department of Conservation and Development.

lakes: Anderson, K. E., 2.

water resources: Adams, M. F.; Griffin, W. C. water-resources policy: Galbraith, W. A.

watershed problems: Mark, F. A.

Waste disposal: Bierschenk, W. H.; Fair, G. M.; Lackey, J. B.

Waste treatment: Hermann, E. R.; Porges, R. Water.

and man: Frank, B.

deep: White, D. E., 2.

demands: Morris, S. B., 3.

general: Buswell, A. M., 2; Graham, J. B., 2; Partridge, E. P.; Symons, G. E., 1, 2; United Nations Review; U.S. Department of Agriculture; University of Missouri; Williams, D. A., 3.

in agriculture: Carreker, J. R.

juvenile: Thomas, H. E., 3.

thermal: White, D. E., 1.

Water conservation: Graham, E. H.; Hoak, R. D., 1; Leopold, L. B., 2; Watson, K. S.

Water policy: Engineering News-Record, 5.

Water power: Ellis, J. D.; Pumphrey, H. L.; Sibley, A. K., 2; Young, L. L.

Water problems.

general: League of Women Voters of the United States; Soil Conservation Society of America, 2.

legislation: Chapman, C. W.; Water Works Engineering, 1.

municipal: Blake, N. M.

solution: Banks, H. O., 2.

Water resources. See also listings of individual States.

administration: Duke University School of Law; Huffman, R. E.; Shih, Y.; Stanley, L. A.

and power: U.S. Commission on Organization of the Executive Branch of the Government (1953-55).

arid lands: Cressey, G. B., 1; White, G. F., 1. bibliography: Council of State Governments, 1. current research: University of California, 1. development: Meginnis, H. G., 1.

economic evaluation: McGauhey, P. H., 2. economics of development: Belcher, P.; Ciriacy-Wantrup, S. V.; Eckstein, O.; McKean, R. N.; Renshaw, E. F.; Stanford Research Institute; U.S. Inter-Agency Committee on Water Resources, 5; Wengert, $\mathrm{N}$.

evaluation: American Society of Civil Engineers, 2.

Florida development: DeGrove, J. M.

general: Callison, C. H.; Gustavson, R. G.; Snider, R. G.; Thomas, R. O., 2; U.S. Soil Conservation Service, 3; Williams, D. A., 5. investigations: Wells, J. V. B., 1.

Iowa: Timmons, J. F.

legislation: Bergen, S. W.

multiple-purpose development: ArkansasWhite-Red Basins Inter-Agency Committee; Dexheimer, W. A.; Hathaway, G. A.; 
Water resources-Continued.

Krutilla, J.; Netboy, A.; Reynolds, R. R.; Stone, A. W.; United Nations, 1.

national policy: American Society of Civil Engineers, 3; Davis, C. A.; Thomas, H. E., 2.

New England-New York: New England-New York Inter-Agency Committee.

North-Central States: Potter, W, E.

Pecos River development: Pecos River Commission.

planning: Banks, H. O., 3.

policy: Branch, H., Jr.; Chamber of Commerce of the United States; Engineering NewsRecord, 12; Moreell, B.; Ridgeway, M. E.; Stein, M.; U.S. Presidential Advisory Committee on Water Resources Policy; Wolman, A., 1.

problems: Holmes, H. B., Jr.; Sterling, C. I., Jr.

research: Taylor, E. H.

saline: Krieger, R. A.; Robinove, C. J.; Winslow, A. G., 1.

State administration: Council of State Governments, 2.

United States: Aandahl, F. G.; Soil Conservation Society of America, 1; Wells, J. V. B., 2; Woodward, D. R.

utilization: Boyce, E.

Western United States: Huberty, M. R.

Water-resources projects, State participation: Kansas Water Resources Board, 2.

Water rights. See Law.

Water spreading. See also Ground water, Infiltration, Soil moisture. Hall, W. A., 1; Orlob, G. T., 2; Pierson, R. K.; Schiff, L., 3.

Water supply.

and drainage: Loehnberg, A., 1.

demands: Morris, S. B., 2.

effect of vegetation: Musgrave, G. W., 4.

engineering: Babbitt, H. E.

forecasting: Arias, E. S.; Dwyer, C. H.; Kohler, M. A., 3.

forecasts: Work, R. A., 4.

forecasts from snow surveys: Beaumont, R. T., 1; Burns, J. I.; Hannaford, J. F., 1; Irving, R. N.; Work, R. A., 1.

general: Clyde, G. D.; Fair, G. M.; Fuhrman, R. E.; Weld, B. A.

in permafrost region: Black, R. F.

inventory: Boyer, M. C., 2.

public: Lohr, E. W.; Metzler, D. F., 1; Waring, F. $\mathrm{H}$.

upstream: Harrold, L. L., 3.

Water-table fluctuations: Code, W. E.

Water utilization.

by industry: Conklin, H. L., 1, 2; Derby, R. L.; Mussey, O. D., 1, 2.

general: Clyde, G. D.; Kohler, K. O., Jr. ground water: Muckel, D. C., 1.

Mississippi Valley: Zadrozny, M. G.

United States: MacKichan, K. A., 1, 2.

waste waters: California Department of Water Resources, 12; California Water Pollution Control Board, 1, 2, 3 .
Water witching. See Dowsing.

Water yield.

agricultural watersheds: Harrold, L. L., 4.

computation: Carpenter, J. D.

effect of vegetation: Burgy, R. H., 2, 4.

forested watersheds: Goodell, B. C., 3; Hewlett, J. D.; Hoover, M. D.

of reservoirs: MacLeman, E. L.

Watershed damage: Gleason, C. H., 1.

Watershed development: Bethlahmy, N., 1; Hope, C. R.

Watershed management.

bibliography: Gleason, C. H., 3.

city supply: Ward, W. W.

data required: Rowe, P. B., 4.

effect on floods: Kautz, H. M.

effect on water quality: Albert, F. A.; Cowlin, R. W.

experimental: Reigner, I. C., 1; Smith, H. A. fish habitat: Packer, P. E., 2.

Forest Service program: Clark, L. K.

forested areas: Goodell, B. C., 4; Heilman, J. M.; Hopkins, W., 3; Lindh, C. O.; Love, L. D., 3; Lull, H. W., 1, 8, 11; Moltke, A.; Nelson, A. W., Jr.; Ningard, L. G.; Tripp, N. R.; U.S. Tennessee Valley Authority; Weitzman, S.

forests and snow: Goodell, B. C., 1; Work, R. A., 3.

general: Ogrosky, H. O., 1, 3; Salmond, G. R. legal aspects: Benson, E. T.

opportunities: Colman, E. A.

personnel training: Wilm, H. G., 1 .

problems: Craddock, G. W., 2; Mark, F. A.; Ogrosky, H. O., 2; Packer, P. E., 1.

rangelands: Love, L. D., 1, 4; Orr, H. K.; Renner, F. G.

research: Ackerman, W. C., 1 ; Anderson, H. E.; Bethlahmy, N., 2; Dunford, E. G., 2, 3; Gregory, G. R.; Harper, V. L.; Hopkins, W., 2; Lull, H. W., 5; Meginnis, H. G., 2; Price, R., 1, 2; Reigner, I. C., 2; Sartz, R. S., 2; Trimble, G. R., Jr., 1.

tests: Rowe, P. B., 5.

Watershed programs.

Arizona: Arizona Water Resources Committee, $1,2$.

engineering: Calkins, R. S.

Kansas Basin: University of Kansas.

research: Craddock, G. W., 1.

sedimentation: Larson, F. H.

Watershed resources: Dortignac, E. J., 1.

Waves.

attenuation: Iwasa, $\mathrm{Y}$.

gravity: Sarpkaya, T.; Wiegel, R. L.

runup: Savage, $R$. P.

solitary: Chappelear, J. E.

wind: Bretschneider, C. L.; Hufft, J. C.; U.S. Corps of Engineers, 1.

\section{Weather.}

Alaska: Mitchell, J. M., Jr.

cloud distribution: Changnon, S. A., Jr., 1.

cycles: Tannehill, I. R., 1.

data: Nelson, C. E.

frequencies: Calef, $W$. 
Weather-Continued.

general: Koeppe, C. E.

theory: Roberts, W. $O$.

thunderstorms: Changnon, S. A., Jr., 2.

United States data: U.S. Weather Bureau, 4.

Weather modification.

cloud formation: Chemical and Engineering News.

convective clouds: Dennis, A. S.

evaluation: Advisory Committee on Weather

Control; Barton, M.; Berry, F. A.; Braham,

R. R., Jr.; Buell, C. E.; Decker, F. W.;

Elliott, R. D.; Krick, I. P., 1; Orville, H. T., 4 ; Spar, J.; Woodbridge, D. D.

general: Bello, F.; California Water Resources

Board, 5; Day, J. A.; Engineering News-

Record, 7; Gardner, C., Jr.; Houghton,

H. G.; Krick, I. P., 2; McLeod, K. T.;

Orville, H. T., 1, 3; Wexler, H.

licensing: California Division of Water Resources, 12.

progress: Orville, H. T., 2.

Puerto Rico: Alpert, L.

scientific basis: Arizona University; Todd,

Wells.

C. J.; Weickmann, H.

collector: Yale, R. A.

construction: Painter, R. H.

flow into: Petersen, J. S.; Zee, C. H.

horizontal: Cressey, G. B., 2.

hydraulics: Peterson, D. F., Jr.

measuring yield: Katz, A.

observation: Rasmussen, W. C., 5.
Wells-Continued.

pumping-test analysis: Bruin, J., 1 .

specific capacity: Bruin, J., 2.

water temperature: Boldizsar, $\mathrm{T}$.

West Virginia.

droughts: Douglass, J. B.

floods: Stringfield, V. T.

ground water: Carlston, C. W.; Nace, R. L., 3. maximum station precipitation: U.S. Weather

Bureau, 7.

water yields: Weitzman, S., 2.

Wetlands: Shaw, S. P.

Wind direction: Brehm, C. D.; Court, A., 1.

Wisconsin.

circulation of lake water: Bryson, R. A., 1. ground water: Drescher, W. J., 2; Harder, A. H.; LeRoux, E. F.

ground-water recharge: Drescher, W. J., 1.

lake ice: Bryson, R. A., 2.

strontium in water: Nichols, M. S.

Wyoming.

ground water: Babcock, H. M.; Bradley, E., 1;

Kohout, F. A.; Rapp, J. R.; Swens on, F. A., 2.

sedimentation: Colby, B. R., 2.

uranium-bearing water: Murphy, J. F.

water quality: Babcock, H. M.; Bradley, E., 1; Colby, B. R., 2; Kohout, F. A.; Rapp, J. R.; Swenson, F. A., 2.

water resources: Wyoming Natural Resource Board.

Yukon River basin: Wardle, J. M. 
U.S. Geological Survey.

Annotated bibliography on hydrology and sedimentation, United States and Canada, 1955/58- Washington, U.S.

Govt. Print. Off., 1962-

v. $24 \mathrm{~cm}$. (Its Water-supply paper 1546

Prepared in cooperation with the Subcommittees on Hydrology and Sedimentation, Inter-Agency Committee on Water Resources.

Compiler: 1955/58-

H. C. Riggs.

(Continued on next card)

(Card 2)

U.S. Geological Survey. Annotated bibliography on hydrology and sedimentation, United States and Canada, 1955/58-

Preceded by Annotated bibliography on hydrology, 1941-1950 and Annotated bibliography on hydrology (1951-54) and sedimentation (1950-54) United States and Canada, both compiled by the American Geophysical Union.

1. Hydrology-Bibl. 2. Sedimentation and deposition-Bibl. I. Riggs, Henry Chiles, 1913-comp. II. U.S. Inter-Agency Committee on Water Resources. III. Title.

(Series) 





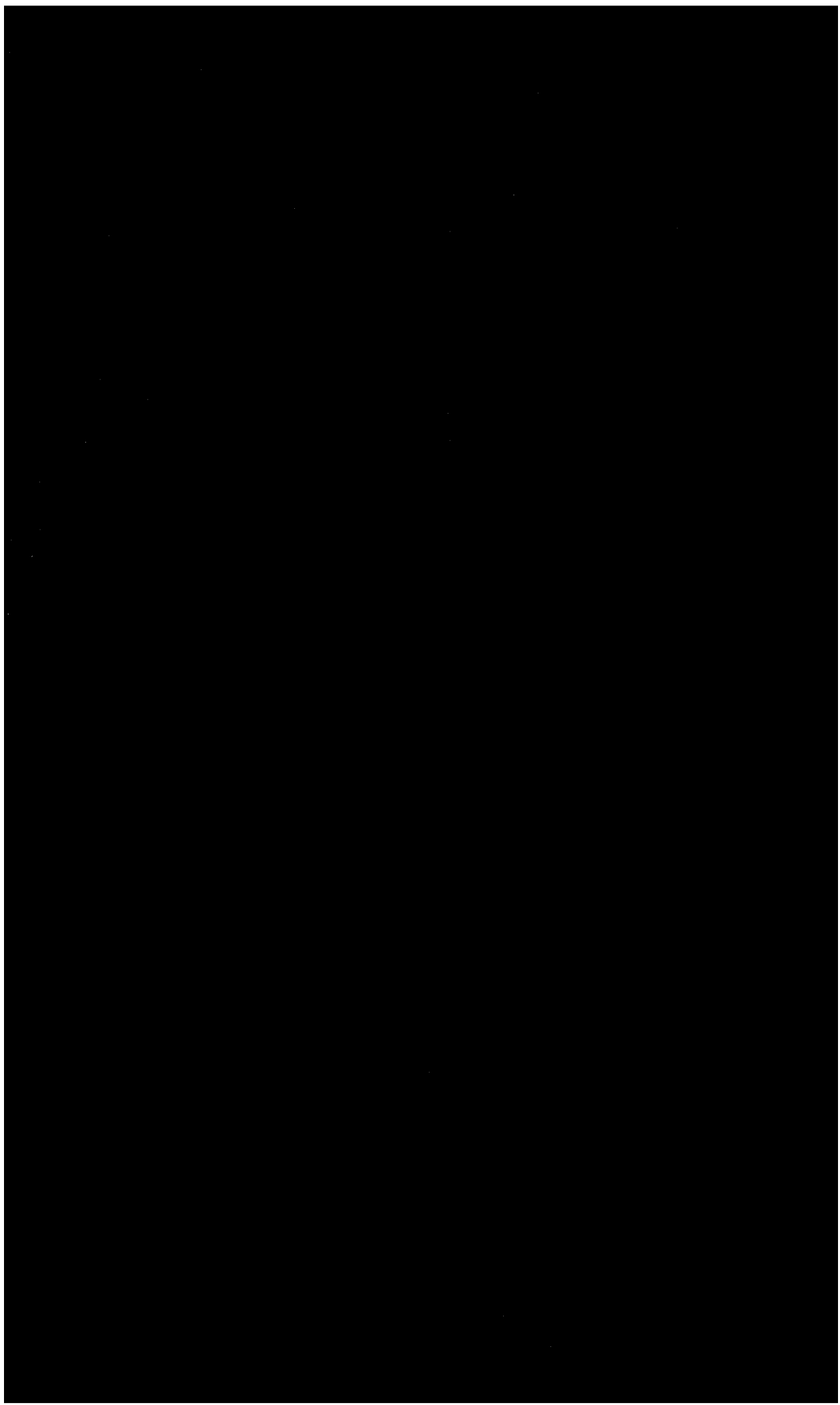




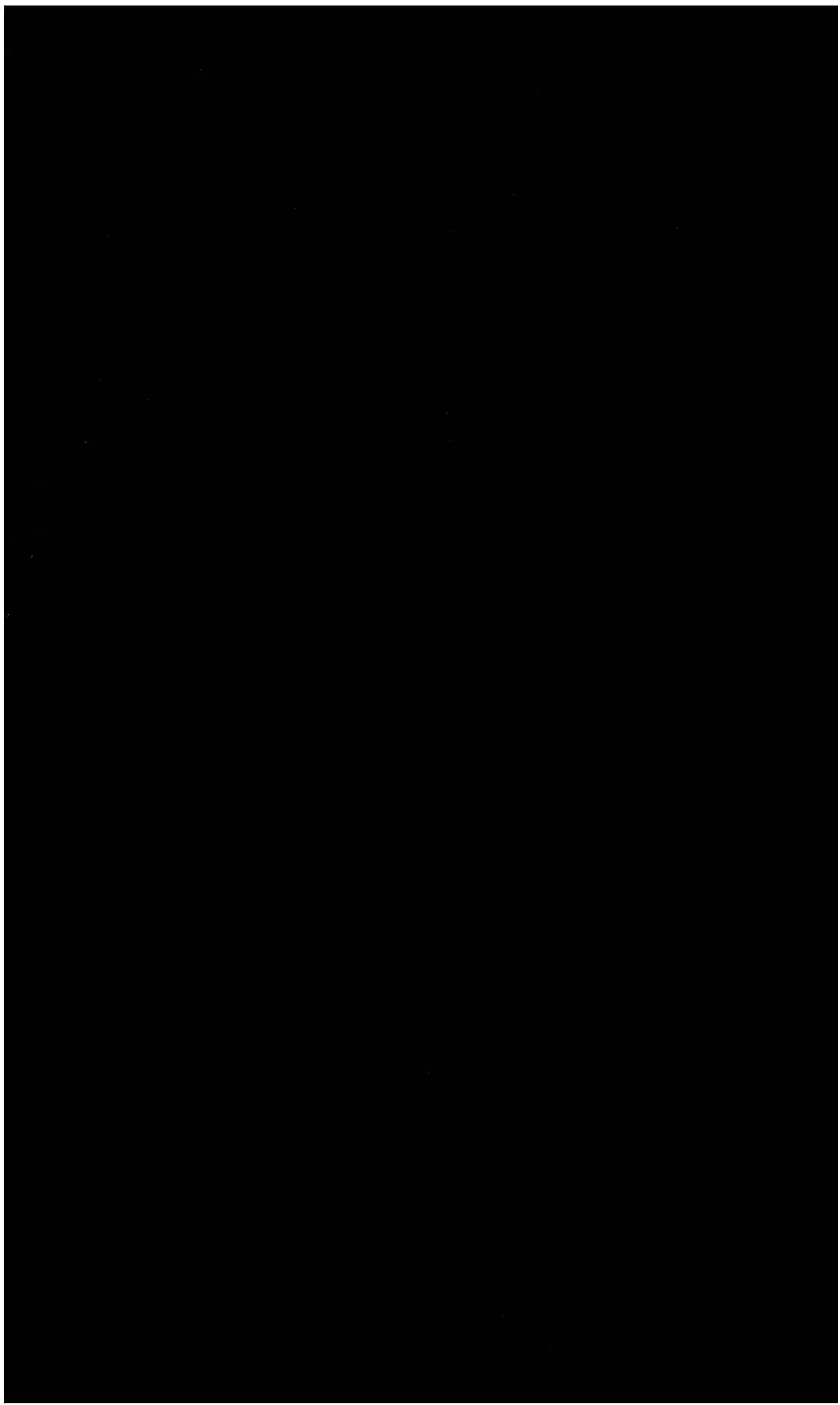

